$$
\begin{gathered}
\text { Universidade de São Paulo } \\
\text { Instituto de Química de São Carlos } \\
\text { Programa de Pós-Graduação em Química }
\end{gathered}
$$

\title{
Metabólitos secundários como potenciais inibidores de CDK8 (proteína quinase humana)
}

\author{
Doutoranda: Buana Carvalho de Almeida
}

Orientadora: Profa. Dra. Fernanda Canduri

Coorientadora: Profa. Dra. Maria Fátima das Graças Fernandes da Silva 
Buana Carvalho de Almeida

Metabólitos secundários como potenciais inibidores de CDK8 (proteína quinase humana)

Tese de doutorado apresentada ao Instituto de Química de São Carlos da Universidade de São Paulo como parte dos requisitos para a obtenção do título de doutor em Ciências.

Área de concentração: Química Orgânica e Biológica

Orientadora: Profa. Dra. Fernanda Canduri

\section{Exemplar revisado}

O exemplar original encontra-se em acervo reservado na biblioteca do IQSC-USP

\section{São Carlos}


Dedico este trabalho a minha amada mãe, Claudete Carvalho, por ser o meu maior exemplo de fé, amor, generosidade e dedicação. 


\section{AGRADECIMENTOS}

$\checkmark$ Agradeço, antes de tudo, a Deus, por ter me sustentado nos momentos mais difíceis desta caminhada, e, principalmente, por me fazer compreender que os planos Dele são muito maiores e melhores que os meus. Obrigada, Senhor, por me abençoar tanto;

$\checkmark$ À minha amada mãe que sempre me proveu de amor, exemplos e que, acima de tudo, me ensinou a lutar e nunca desistir dos meus sonhos. Agradeço especialmente aos meus familiares queridos e mais próximos, que acompanharam a minha trajetória acadêmica;

$\checkmark$ Ao meu amado e paciente marido, Bartholomeu Araújo, por me dar amor e carinho, quando eu mais precisei, nos difíceis momentos longe de casa. Agradeço, especialmente, por me ajudar em várias etapas de desenvolvimento do meu projeto, contribuindo sempre para melhorar o meu trabalho;

$\checkmark$ À gentil e querida orientadora, Profa. Dra Fernanda Canduri, por me aceitar como a sua primeira aluna de doutorado. Obrigada pela oportunidade de aprender com você e de ser a responsável por despertar o meu amor pela área.

$\checkmark$ Aos amigos do Laboratório de Bioquímica Molecular e Estrutural - BioQEst: Diandra, Rebeka, Jessyka, Hélio, Célia, Cecília e Nikolas. Muito obrigada pela amizade, carinho e também pelas contribuições para o meu trabalho. Eu, sem dúvidas, aprendi bastante com vocês.

$\checkmark$ Aos amigos Tarcilane e Laudmir que foram/são uma família para mim. Não tenho palavras para agradecer pela prestatividade e carinho.

$\checkmark$ Aos amigos especiais que fiz em São Carlos, em especial a Larissa (vizinha), Camila e Naiza, que foram maravilhosas comigo. Agradeço pela amizade e carinho.

$\checkmark$ Aos amigos piauienses que estavam em São Carlos: Éverton, Vitor, Roberto, Isabella, Érika e Luís Paulo.

$\checkmark$ Ao Laboratório de Produtos Naturais da UFSCAR, em especial a Profa. Dra. Maria Fátima das Graças Fernandes da Silva e à aluna de doutorado Hocelayne. 
$\checkmark$ Agradeço, em especial, a minha amiga Poliana Souza, por compartilhar comigo vários momentos em São Carlos.

$\checkmark$ Ao amigo do laboratório de Produtos Naturais, Edenilson Niculau, por me ensinar e auxiliar nas análises de HPLC-MS.

$\checkmark$ Ao Laboratório de Química Medicinal do IQSC-USP, coordenado pelos professores Dr. Carlos Alberto Montanari e Dr. Andrei Leitão.

$\checkmark$ Ao Laboratório da Profa Dra. Dulce Helena Ferreira de Souza, do Departamento de Química da Universidade Federal de São Carlos, UFSCar.

$\checkmark$ Ao Laboratório de Bioanalítica, Microfabricação e Separações - BioMics, ISQC/USP sob coordenação do Prof. Dr. Emanuel Carrilho.

$\checkmark$ Ao Laboratório de Biologia de Sistemas Computacionais, coordenado pelo professor Dr. Walter Filgueira de Azevedo Jr., que contribuiu substancialmente para este trabalho.

$\checkmark$ Ao Laboratório de biofísica do IFSC-USP.

$\checkmark$ Às agências de fomento à pesquisa CAPES e FAPESP, pelo apoio financeiro para a execução deste trabalho.

$\checkmark$ À coordenação de Pós-Graduação em Química do IQSC-USP, em especial aos funcionários pelo excelente atendimento ao público. 
Ora, a fé é a certeza daquilo que esperamos e a prova das coisas que não vemos

Hebreus, 11:1 


\section{RESUMO}

Quinases Dependentes de Ciclinas (CDKs) são holoenzimas que possuem uma subunidade catalítica, a CDK, e uma subunidade regulatória, a ciclina. CDKs são Ser/Thr quinases, ou seja, fosforilam resíduos de aminoácidos específicos. A CDK8 fosforila o CTD da RNA Pol II, sendo considerada como regulador transcricional positivo, implicando em efeitos oncogênicos. Em suma, essas descobertas a colocam como alvo de drogas em pesquisas relacionadas ao câncer. Técnicas de biologia molecular foram realizadas a fim de obter o recombinante pET28a::cdk8 4 , sem a presença de códons raros para Escherichia coli. A CDK8 $\Delta$-HisTag foi expressa em Rosetta(DE3), com cauda de histidina no N-terminal ( $45 \mathrm{kDa})$, no entanto a proteína foi expressa como corpos de inclusão. Desta forma, a CDK8 4 HisTag foi solubilizada com SDS 2\%, o detergente foi completamente removido e o reenovelameno da mesma foi obtido com cromatografia líquida de alta eficiência utilizando coluna de $\mathrm{Ni}^{2+}$. A proteína reenovelada e purificada foi analisada por dicroísmo circular e revelou a existência de $13,0 \%$ de hélices $\alpha ; 31,9 \%$ de folhas $\beta$; $35,4 \%$ de regiões randômicas e $20,1 \%$ de voltas $\beta$. O espectro de emissão de fluorescência da CDK8 $\Delta$-HisTag mostrou comprimento de onda máximo de emissão em torno de $360 \mathrm{~nm}$. O screening virtual com potenciais inibidores obtidos da espécie Waltheria brachypetala revelou o alcaloide waltheriona E como potencial inibidor de CDK8. Este é o primeiro relato de expressão e purificação da proteína CDK8 em E. coli, assim como do screening virtual desta proteína na presença de inibidores naturais obtidos de W. brachypetala.

Palavras Chave: CDKs, Clonagem, Expressão, Inibidores, Docking 


\begin{abstract}
Cyclin Dependent Kinases (CDKs) are holoenzyme having a catalytic subunit, CDK, and a regulatory subunit, cyclin. CDKs are Ser / Thr kinases, which phosphorylate specific amino acid residues. The CDK8 phosphorylates the CTD of RNA Pol II. It is considered a positive transcriptional regulator, resulting in oncogenic effects. In short, these findings pose as a drug target in research related to cancer. Molecular biology assays were performed in order to obtain the recombinant pET28a::cdk8 $\Delta$, without the presence of rare codons for Escherichia coli. CDK8D-HisTag was expressed in Rosetta (DE3), with a N-terminal tail histidine ( $45 \mathrm{kDa})$, however, the protein was expressed as inclusion bodies. In this way, a CDK8 $\Delta$-HisTag was solubilized with $2 \%$ SDS, then the detergent was completely removed and the refolding of the same was obtained with High Performance Liquid Chromatography using $\mathrm{Ni}^{2+}$ column. $\mathrm{A}$ refolded and purified protein for circular dichroism analysis revealed the existence of $13.0 \%$ a-helices; $31.9 \% \beta$ sheets; $35.4 \%$ of random regions and $20.1 \%$ of $\beta$-turns. The fluorescence emission spectrum of CDK8 $\Delta$-HisTag showed the maximum wavelength around $360 \mathrm{~nm}$. Virtual screening with potential inhibitors of the Waltheria brachypetala species revealed waltherione $\mathrm{E}$ alkaloid as a potential inhibitor of CDK8. This is the first report of expression and purification of the CDK8 protein in $E$. coli, as well as the virtual screening of this protein in the presence of natural inhibitors obtained from $W$. brachypetala.
\end{abstract}

Keywords: CDKs, Cloning, Expression, Inhibitors, Docking 


\section{LISTA DE ABREVIATURAS E SIGLAS}

AcOEt - Acetato de etila

Arg - Arginina

Asn - Asparagina

Asp - Aspartato

ATP (Adenosine Triphosphate) - Trifosfato de adenosina

AUC (Area Under Curve) - Área sob a curva

BLAST (Basic Local Alignment Search Tool) - Ferramenta básica de pesquisa de

alinhamento local

CAK (CDK Activating Kinase) - Quinase ativadora de outras quinases

$\mathrm{CC}$ - Cromatografia em coluna

CCD - Cromatografia em Camada Delgada

CDKs (Cyclin Dependent Kinase) - Quinase dependente de ciclina

CKII (Casein Kinase II) - Caseína quinase II

CKIs (Cyclin Dependent Kinase Inhibitors) - Inibidores de quinases dependentes de ciclinas

CTD (Carboxy Terminal Domain) - Domínio carboxi terminal

CV (Colum Value) - Volume de coluna

DCM - Diclorometano

DFG - Aspartato, fenilalanina e glicina

DMG - Aspartato, metionina e glicina

DNA (Deoxyribonucleic Acid) - Ácido desoxirribonucleico

E.C (Enzyme Commition Numbers) - Números de classificação enzimática

EF (Enrichment Factors) - Fatores de enriquecimento

ERa (Estrogen Receptor Alpha) - Receptor de estrogênio alfa

Fw (Foward) - primer direto

Glu - Glutamato

HMD (Hymenialdisin) - Hymenialdisina

HPLC (High Pressure Liquid Cromatograph) - Cromatografia líquida de alta pressão HUVECs (Human Umbilical Vein Endothelial Cell) - Célula endotelial de veia umbilical humana

Ki (Inhibitory Constant) - constante de inibição

LB - Luria Bertani 
LC-MS (Liquid Chromatograph-Mass Espectrometry) - Cromatografia líquida acoplada a espectrometria de massas

Leu - Leucina

Lys - Lisina

$\mathrm{MeOH}-$ Metanol

MRM (Multiple Reaction Monitoring) - Monitoramento de reações múltiplas

NCBI (National Center for Biotecnology Information) - Centro Nacional de

Informação Biotecnológica

PCR (Polymerase Chain Reaction) - Reação em cadeia da polimerase

PDB (Protein Data Bank) - Banco de dados de proteínas

PKC (Protein Kinase C) - Proteína quinase C

PPase (Pyrophosphatase inorganic) - Pirofosfato inorgânico

$\mathrm{Rb}$ - Retinoblastoma

Rev (Reverse) - primer reverso

RMN - Ressonância Magnética Nuclear

RMSD (Root Mean Square Desviation) - Desvio quadrático médio

RNA (Ribonucleic Acid) - Ácido ribonucleico

ROC (Receiver Operating Characteristics) - Características de operação do receptor

SAnSReS (Statistical Analysis of Docking Results and Scoring Functions) - Análises

estatísticas de resultados de docking e funções scoring

SDS-PAGE (Sodium Dodecyl Sulphate Polyacrylamide Gel Electrophoresis) -

Eletroforese em gel de poliacrilamida e dodecil sulfato de sódio

SEC (Super Elongation Complex) - Complexo de super elongação

Ser - Serina

SNX (Senextin) - Senextina

SOB - Super Optimal Broth - Meio de crescimento celular otimizado

Thr - Treonina 


\section{LISTA DE FIGURAS}

Figura 1 - Elementos de estrutura secundária do complexo CDK8-Ciclina C. Em azul, a subunidade catalítica, a CDK8, e na cor rosa, a subunidade regulatória, a ciclina C.

Figura 2 - Reação de fosforilação do aminoácido treonina realizado pela CDK......... 22

Figura 3 - Ativação do complexo CDK8/Ciclina C.

Figura 4 - Alinhamento da sequência de aminoácidos da CDK2 (Genbank CAA43985.1) e CDK8 (Genbank CAA59754.1). Em vermelho, na sequência da CDK2, o domínio PSTAIRE (conservado entre grande parte das CDKs, porém não observado na sequência da CDK8). Em verde, os resíduos conservados de Arginina (Arg50, Arg65 e Arg178). Em rosa, os motivos DFG, seguido de leucina (amarelo), e DMG seguido de fenilalanina (amarelo) da CDK2 e CDK8, respectivamente. Em azul, na sequência da CDK8, a inserção de nove resíduos $\left({ }^{240}\right.$ EDIKTSNPY $\left.{ }^{248}\right)$......

Figura 5 - Diferenças peculiares da Quinase Dependente de Ciclina 8 - CDK8.

Figura 6 - Fases do ciclo de divisão celular e checkpoints.

Figura 7 - Fase do ciclo celular regulada pela CDK8

Figura 8 - Transcrição do DNA

Figura 9 - Estrutura cristalina da RNA-Polimerase II durante a transcrição. Na cor laranja, está representada a dupla hélice de DNA.

Figura 10 - Fases da transcrição (iniciação, alongamento e terminação) e os diferentes padrões de fosforilação do CTD da RNA Pol II. O CTD (linha ondulada) é representado por cores diferentes (diferentes padrões de fosforilação) em cada etapa da transcrição. Diferentes padrões de fosforilação significam que diferentes fatores de transcrição (TFIIH, PTEFb e PPase) se ligam à RNA Pol II em fases distintas do processo transcricional.

Figura 11 - Estratégias de inibição de CDKs.

Figura 12 - Inibidores naturais de CDKs e seus análogos (SHARMA; SHARMA; TYAGI, 2008).

Figura 13 - Cortistatinas. Os números entre parênteses são os valores de $\mathrm{IC}_{50}$ para atividade antiproliferativa contra Células Endoteliais da Veia Umbilical Humana (HUVECs)

Figura 14. Sorafenibe e outros inibidores de CDK8...

Figura 15 - Compostos da classe SNX (Senextinas) como inibidores de CDK8. 
Figura 17 - Mapa do vetor pCR-Blunt (Invitrogen)

Figura 18 - Mapa da estrutura secundária da proteína CDK8, mostrando as regiões desordenadas (quadrinhos em vermelho) no N- e C-terminais. Quadrinhos em lilás correspondem às regiões de hélices $\alpha$ e quadrinhos em amarelo, regiões de folhas $\beta$.

Figura 19 - Gráfico do perfil de desordem intrínseca da proteína CDK8. Os últimos 150 resíduos de aminoácidos da cadeia polipeptídica possuem score em torno de 1, demonstrando região de alta desordem.

Figura 20 - Sequência de cDNA da CDK8. Em vermelho, estão destacados os nucleotídeos correspondentes às regiões desordenadas que foram removidos

Figura 21 - Sequência do cDNA que codifica a CDK8 sem os nucleotídeos correspondentes à região desordenada da proteína.

Figura 22 - Alinhamento das sequências do cDNA da CDK8 obtido na PCR contra a referência (gi:4502744)

Figura 23 - Sequência do cDNA codificante da proteína CDK8 $\Delta$. A) sequência com códons raros destacados em vermelho. B) sequência sem os códons raros em $E$. coli.

Figura 24 - Gel de agarose 0,8\% mostrando o produto da clivagem do recombinante pEt28a::cdk8 $\Delta$. A banda em 1000 pb é referente ao cDNA da CDK8А.

Figura 25 - Análise do sequenciamento do plasmídeo recombinante. A sequência com a identificação cdk8 é a referência. Nas caixas em vermelho estão os códons de iniciação e terminação.

Figura 26 - SDS-PAGE 15\% mostrando o padrão de expressão da CDK8 $\Delta$ a 18 e $20^{\circ} \mathrm{C}$

Figura 27 - SDS-PAGE 15\% mostrando a expressão da CDK8 $\Delta$ em diferentes concentrações de indutor (a) e diferentes tempos de indução (b) utilizando 0,2 mM de IPTG em meio LB.

Figura 28 - SDS-PAGE 15\% mostrando o padrão de expressão da CDK8 em diferentes tempos de indução (1h, $2 \mathrm{~h}, 3 \mathrm{~h}$, $4 \mathrm{~h}$ e overnight) com 0,2 mM de IPTG utilizando o meio otimizado.

Figura 29 - SDS-PAGE 15\% mostrando o padrão de expressão da CDK8 em meio LB e meio otimizado a $20^{\circ} \mathrm{C}$ com $0,2 \mathrm{mM}$ de IPTG, overnight.

Figura 30 - SDS-PAGE 15\% mostrando a superexpressão da CDK8 em células transformadas de Rosetta(DE3) e a expressão do grupo controle (não transformado). 
Figura 31- Gel 2D da fração solúvel do lisado contendo a proteína CDK8 0 marcador de massa molecular empregado foi o Unstained Protein Marker (Thermo Scientific)

Figura 32 - Resultado do ensaio de western blot para avaliar a expressão e solubilidade da CDK8 $\Delta$-HisTag na fração solúvel do lisado.

Figura 33 - SDS PAGE 15\% mostrando as frações eluidas da CDK8 $\Delta$-HisTag desnaturada, a partir da coluna de afinidade ao $\mathrm{Ni}^{2+}$

Figura 34 - Perfil cromatográfico do sobrenadante (lisado) contendo a CDK8 4 HisTag desnaturada, utilizando cromatografia de interação hidrofóbica.....

Figura 35 - SDS PAGE 15\% mostrando o padrão das amostras obtidas utilizando o protocolo de solubilização e reenovelamento descrito por Upadhyay et al, (2016). Figura 36 - Perfil cromatográfico da fração contendo a CDK8D-HisTag, eluída a partir da coluna de afinidade ao $\mathrm{Ni}^{2+}$

Figura 37 - Perfil cromatográfico da fração contendo a CDK8 $\Delta$-HisTag, eluída a partir da coluna de afinidade ao $\mathrm{Ni}^{2+}$ e a relação entre o percentual do tampão $\mathrm{B}$ (sem imidazol) versus quantidade de CV (volume de coluna)....

Figura 38 - SDS-PAGE 15\% mostrando as frações coletadas da CDK8 $\Delta$-HisTag a partir da coluna de afinidade ao $\mathrm{Ni}^{2+}$ utilizando um gradiente linear de $300 \mathrm{mM}$ de imidazol em tampão Hepes pH 7,5.

Figura 39 - Espectro de dicroísmo circular da CDK8 $\Delta$-HisTag em tampão Hepes $50 \mathrm{mM}, \mathrm{NaCl} 150 \mathrm{mM}$.

Figura 40 - Espectro de emissão de fluorescência da CDK8 $\Delta$-HisTag obtido em tampão Hepes 50 mM, NaCl 150 mM.

Figura 41 - Alcaloides ciclopeptídicos isolados das raízes de $W$. brachypetala......... 95 Figura 42 - Alcaloides quinolônicos isolados das raízes e caule de $W$. brachypetala.......

Figura 43 - Espectro de Massas (A - E) de frações da fase AcOE obtida das folhas de $W$. brachypeta (experimento de MRM/ LC-MS).

Figura 44 - Espectro de RMN de ${ }^{13} \mathrm{C}$ da fração WFA-94-15-20 $\left(\mathrm{CDCl}_{3}, 100 \mathrm{MHz}\right) \ldots \quad 103$

Figura 45 - Espectro de RMN ${ }^{13} \mathrm{C}$ da fração WFH34-15-17 $\left(\mathrm{CDCl}_{3}, 100 \mathrm{MHz}\right) \ldots \ldots \ldots . .104$

Figura 46 - Espectro de RMN ${ }^{1} \mathrm{H}$ da fração WFH-30 (MeOD, $\left.400 \mathrm{MHz}\right) \ldots \ldots \ldots \ldots \ldots \ldots \ldots . . . . . . . . .105$

Figura 47 - Espectro de RMN ${ }^{1} \mathrm{H}$ da fração WFH-34-15-17 $\left(\mathrm{CDCl}_{3}, 400 \mathrm{MHz}\right) \ldots \ldots \ldots . . .106$

Figura 48 - Espectro de RMN ${ }^{13} \mathrm{C}$ da fração WFH-34-15-17 $\left(\mathrm{CDCl}_{3}, 100 \mathrm{MHz}\right) \ldots \ldots \ldots .106$

Figura 49 - Figura 49 - Screening Virtual utilizando a ferramenta de docking molecular para a descoberta de drogas potenciais.

Figura 50 - A) Estrutura cristalográfica 4ACM, em verde está a esfera de 
docking centrada no ligante ativo. B) Resultados de Re-docking, onde temse um cluster de 1000 poses mostrado em vermelho. C) MolDock Score vs docking RMSD para a região de mais baixo score. D) Pose para o mais baixo MolDock Score (vermelho) e a posição cristalográfica para o ligante (cinza), como referência.

Figura 51 - MolDock Score and docking RMSD. A) Dados para as CDKs. B) Dados para CDK8

Figura 52 - A) $\log \left(\mathrm{K}_{\mathrm{i}}\right)$ predito versus $\log \left(\mathrm{K}_{\mathrm{i}}\right)$ observado. Os valores para $\log \left(\mathrm{K}_{\mathrm{i}}\right)$ predito foram calculados usando a equação polinomial 308. B) Moléculas de água cristalográficas no sítio de ligação ao ATP indicados pelos pontos vermelhos. Resíduos carregados e envolvidos em interações intermoleculares também são indicados. C) Superfície eletrostática molecular para o sítio de ligação ao ATP. Superfícies carregadas positivamente e negativamente são mostradas em azul e vermelho, respectivamente. Superfícies neutras são indicadas em branco. D) Curva ROC para SV com ligantes ativos são mostrados em vermelho. A linha tracejada é para dados aleatórios. Figuras $\mathrm{A}$ e $\mathrm{C}$ foram obtidas usando o programa MVD (THOMSEN; CHRISTENSEN, 2006) e considerando a estrutura 4ACM (BERG

et al., 2012)

Figura 53 - Estrutura dos produtos naturais utilizados no screening virtual frente à proteína CDK8.

Figure 54 - Principais resíduos da CDK8 envolvidos em interações intermoleculares com 0 ligante WaltherionaE. 


\section{LISTA DE TABELAS}

Tabela 1 - Inibidores de CDKs e seus respectivos alvos.

Tabela 2 - Oligonucleotídeos (primers) utilizados na amplificação do cDNA a partir do plasmídeo recombinante pET28::cdk8a (Epoch Life Science). Os sítios de restrição estão destacados em negrito.

Tabela 3 - Condições reacionais da PCR.

Tabela 4 - Programa do termociclador utilizado na amplificação do cDNA, utilizando um gradiente de temperatura entre 59,7 e $67^{\circ} \mathrm{C}$

Tabela 5 - Reação de ligação do vetor pCR-Blunt ao cDNA da CDK8 utilizando a T4 DNA Ligase (Thermo Scientific).

Tabela 6 - Reação de PCR utilizando o novo primer pET $\mathrm{Fw}_{\mathrm{w}}$ e a enzima Taq $\mathrm{HiFi}$............ 55 Tabela 7 - Condições utilizadas na reação de amplificação para fragmentos maiores que $\mathrm{kb}$

Tabela 8 - Reação de PCR utilizando o novo primer pET $\mathrm{Fw}_{\mathrm{w}}$ e a enzima Phusion Hot Start II (Thermo Scientific).

Tabela 9 - Condições utilizadas na reação de amplificação para fragmentos maiores que

$\mathrm{kb}$

Tabela 10 - Reação de PCR utilizada na amplificação do cDNA da CDK8, a partir de bibliotecas de cDNA de cérebro fetal e de leucócitos.

Tabela 11 - Condições reacionais utilizadas na amplificação de fragmentos maiores que $3 \mathrm{~kb}$

Tabela 12 - Reação de clivagem do produto de PCR para obtenção de extremidades complementares ao vetor de expressão pET28a.

Tabela 13 - Reação de ligação do cDNA da CDK8 ao vetor pET28a.

Tabela 14 - Reação de digestão do DNA da CDK8 e do vetor de expressão pET28a.

Tabela 15 - Reagentes utilizados na reação de ligação pET28a::cdk8 $\Delta$.

Tabela 16 - Reagentes utilizados no teste de restrição.

Tabela 17 - Resultado da amplificação pela PCR utilizando como moldes o gene sintético, biblioteca de cDNA de cérebro fetal e leucócitos

Tabela 18 - Valores das concentrações dos produtos de ligação transformados 
em diferentes cepas de E. coli.

Tabela 19 - Correlação entre funções scoring e $\log \left(\mathrm{K}_{\mathrm{i}}\right)$

Tabela 20 - Correlação entre funções scoring e afinidade de ligação experimental $\log \left(\mathrm{K}_{\mathrm{i}}\right)$

Tabela 21 - Valores de afinidade de ligação preditos pelo MVD e funções scoring Polscore\#308. Posições dos ligantes para predição de valores da afinidade de ligação foram obtidos usando o protocolo 4 para o MVD 


\section{SUMÁRIO}

CAPÍTULO 1 - Clonagem, expressão, purificação e caracterização da CDK8............... 19

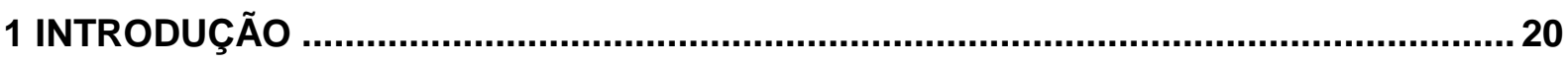

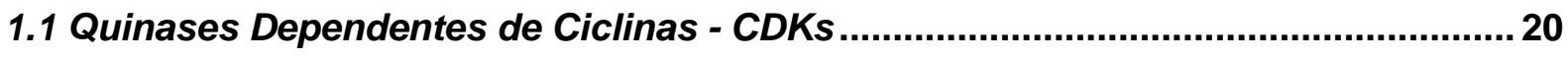

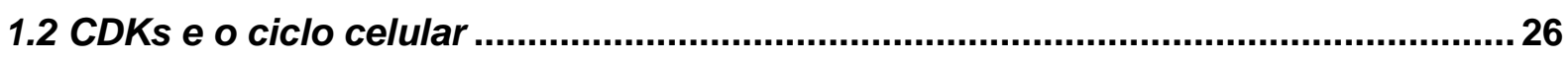

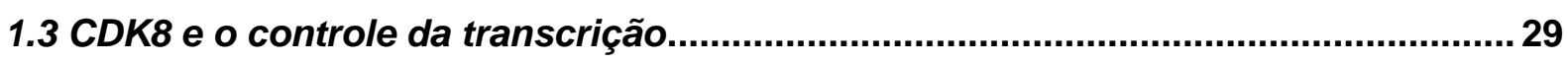

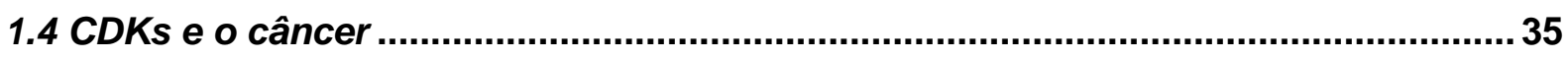

1.5 Inibidores de CDKs naturais e seus análogos..................................................... 37

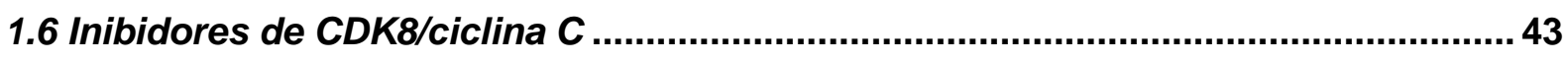

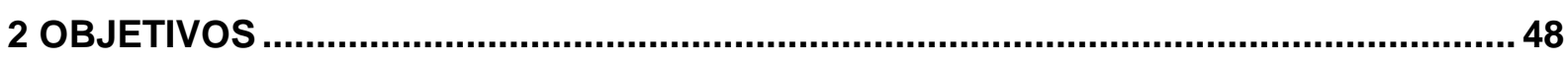

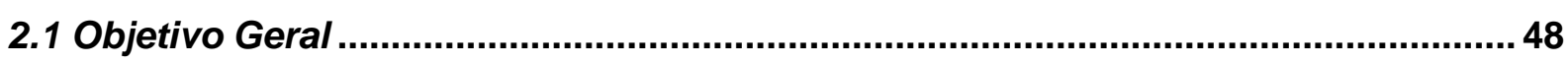

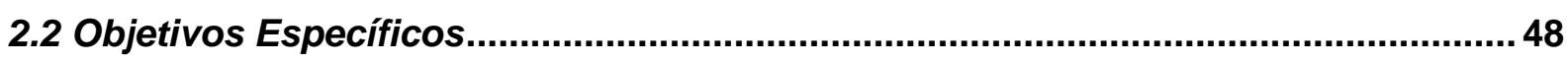

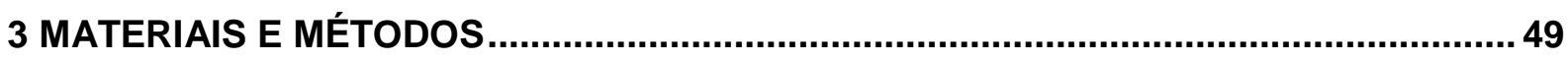

3.1 Data Mining e bioinformática ............................................................................... 49

3.2 Amplificação do cDNA da CDK8 a partir do plasmídeo recombinante pET28a::cdk8 50

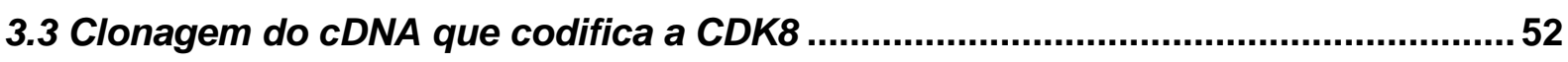

3.3.1 Ligação do cDNA ao vetor de propagação pCR-Blunt ................................................... 52

3.3.2 Ligação do cDNA da CDK8 ao vetor de expressão pET28a......................................... 54

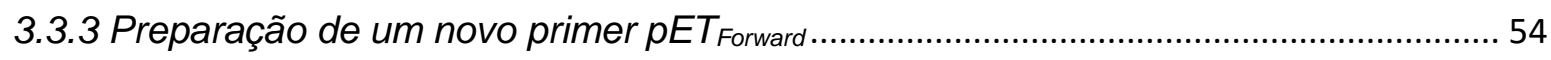

3.4 Amplificação e clonagem do cDNA da CDK8 a partir de biblioteca de cDNA de

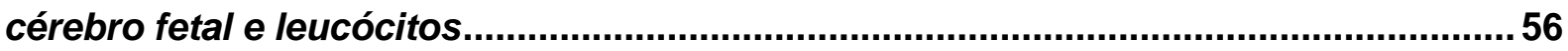

3.5 Obtenção da sequência codificante da CDK8 sem códons raros ............................60

3.5.1 Obtenção do recombinante pET28a::cdk8 ................................................................ 60

3.5.2 Expressão da CDK84-HisTag em E. coli................................................................. 63

3.6 Protocolos de solubilização da proteína CDK8 obtida em corpos de inclusão e

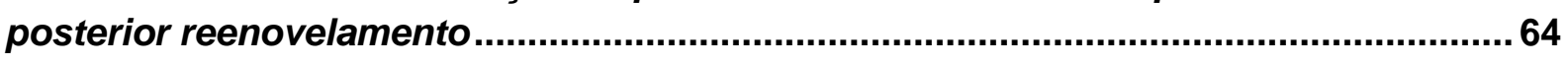

3.6.1 Solubilização pelo trifluoroetanol - TFE ...................................................................... 64

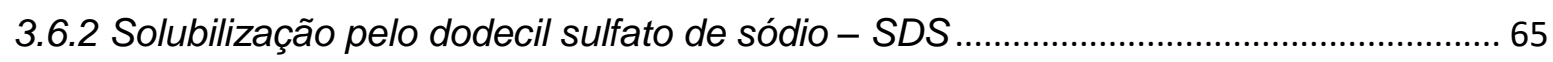

3.7 Purificação da CDK8 utilizando cromatografia de afinidade .................................... 65

3.8 Análise da CDK8 por eletroforese bidimensional - 2D .......................................... 66

3.9 Determinação da CDK8 por Western Blot ................................................................ 67

3.10 Caracterização estrutural .................................................................................. 67

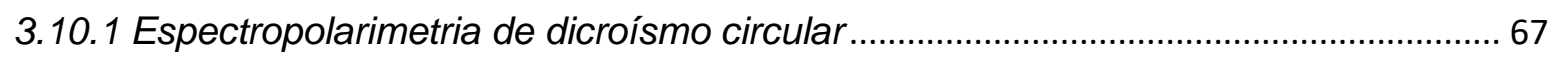

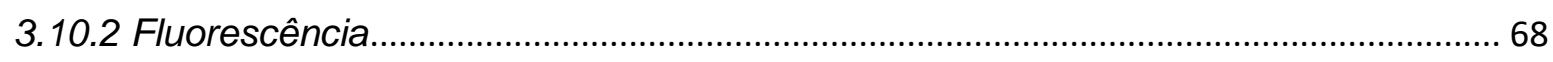


4.1 Amplificação e clonagem do cDNA da CDK8 a partir do plasmídeo recombinante pET28a::cdk8 sintético e de bibliotecas de cDNA...........................................................69

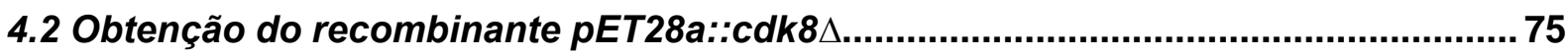

4.3 Expressão da proteína CDK8 $\Delta$-HisTag em E. coli ..................................................... 78

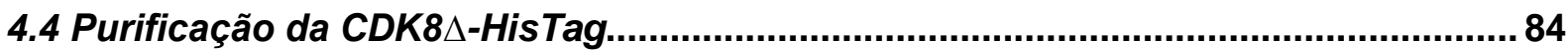

5 Análise estrutural da proteína CDK84-HisTag por espectropolarimetria de dicroísmo

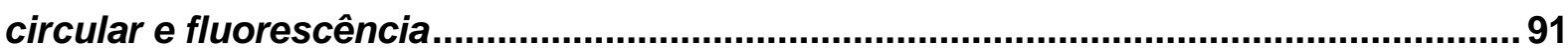

CAPÍTULO 2 - Produtos Naturais............................................................................. 93

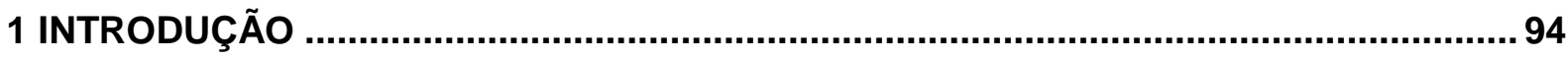

1.1 Potenciais inibidores obtidos da espécie Waltheria brachypetala...........................94

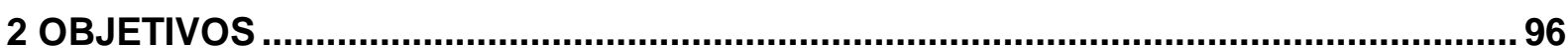

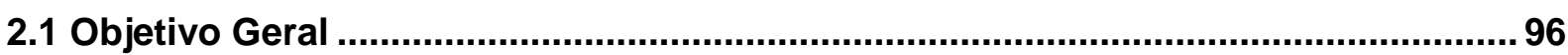

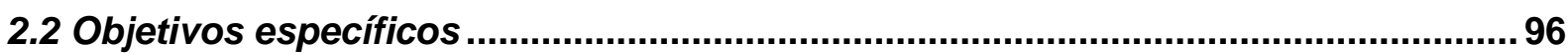

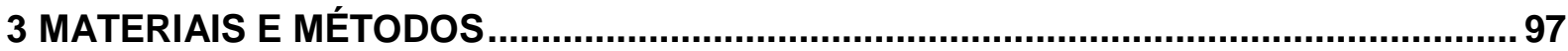

3.1 Coleta e identificação do material vegetal .............................................................. 97

3.2 Preparo dos extratos e isolamento dos metabólitos................................................97

3.3 Métodos de determinação estrutural.............................................................................99

3.3.1 Espectrometria de Ressonância Magnética Nuclear de ${ }^{1} \mathrm{H}$ e ${ }^{13} \mathrm{C}$................................. 99

3.3.2 Análise por Cromatografia Líquida acoplada a Espectrometria de Massas (LC-MS) 99

4 RESULTADOS E DISCUSSÃO................................................................................ 101

4.1 Identificação e isolamento de metabólitos de Waltheria brachypetala................... 101

4.1.2 Identificação do alcaloide brachytelona por análise de $\mathrm{RMN}^{1} \mathrm{H}$ e ${ }^{13} \mathrm{C}$....................... 102

4.1.3 Identificação da mistura de triterpenos composta por betulina e eritrodiol ................ 103

4.1.4 Identificação do flavonoide 5, 7, 3', 4'-tetrametoxicatequina........................................ 104

4.1.5 Identificação da mistura composta por sitosterol e estigmasterol .............................. 105

CAPÍTULO 3 - Docking molecular.............................................................................. 107

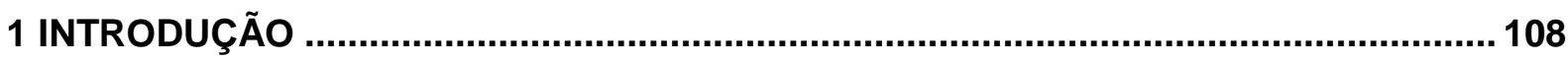

1.1 Ferramenta de interação proteína-ligante: Docking molecular ............................. 108

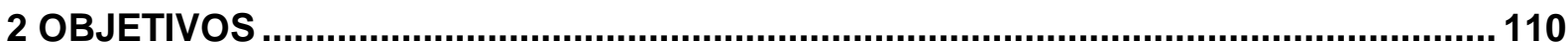

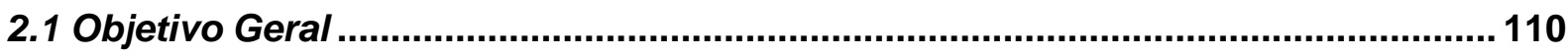

2.2 Objetivos Específicos.............................................................................................. 110

3 MATERIAIS E MÉTODOS.................................................................................... 111

3.1 Análise computacional da interação proteína-ligante utilizando a ferramenta

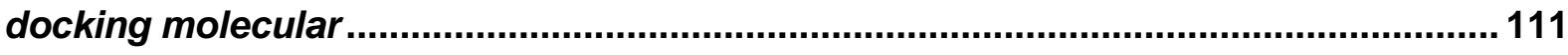

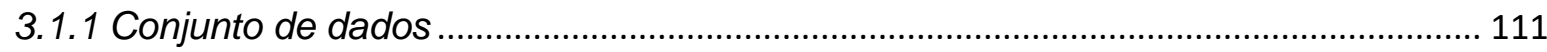


3.1.2 Simulações de docking molecular

3.1.3 Screening Virtual.

4 RESULTADOS E DISCUSSÃO.. 114

4.1 Análise computacional e estatística dos parâmetros estruturais . 114

4.2 Screening Virtual com Produtos Naturais. 119

5 CONCLUSÃO 123

REFERÊNCIAS BIBLIOGRÁFICAS. 125 


\section{CAPÍTULO 1}

Clonagem, expressão, purificação e caracterização da CDK8 


\section{INTRODUÇÃO}

\subsection{Quinases Dependentes de Ciclinas - CDKs}

Segundo Harper e Adams (2001), Quinases Dependentes de Ciclinas (CDKs) são holoenzimas que possuem uma subunidade catalítica, a CDK, e uma subunidade regulatória, a ciclina.

Estruturalmente, uma proteína quinase consiste de um pequeno domínio $\mathrm{N}$ terminal, formado por folhas- $\beta$ e um grande domínio $C$-terminal (CTD), formado por hélices- $\alpha$ (Fig. 1). Entre estes domínios existe um sítio de ligação ao ATP (Fig. 1). O genoma humano contém 21 genes que codificam CDKs (MALUMBRES et al., 2009). Estas desempenham papel importante na regulação do ciclo celular eucariótico, expressão gênica, regulação transcricional, metabolismo e diferenciação neuronal (DOONAN; KITSIOS, 2009), (PEYRESSATRE et al., 2015).

CDKs são Ser/Thr quinases. A Figura 2 mostra a reação de fosforilação do aminoácido treonina, realizado por uma CDK (SMITH et al., 2011). Em 2009, segundo Leitch, Haslett e Rossi (2009), foram identificadas 13 CDKs e 25 ciclinas, no entanto, após 5 anos, Malumbres et al., (2014) relataram a existência de 20 CDKs e 29 ciclinas presentes em células humanas e embora haja alta homologia estrutural entre elas, suas funções são variadas.

A CDK8 se associa à ciclina $C$ para se tornar ativa (Fig. 3). Contudo, o complexo CDK8/Ciclina $C$ necessita ainda da fosforilação por outra quinase, a CDK7, na região do sítio de ligação da RNA Polimerase II (RNA Pol II), para ter sua atividade aumentada. Existem vários aminoácidos que podem ser fosforilados, no entanto, somente quando a Ser182 está fosforilada ocorre uma mudança conformacional no sítio que favorece a ligação ao ATP (Fig. 3) (RZYMSKI et al., 2015).

Com base na comparação da sequência de aminoácidos da CDK2, uma quinase bastante estudada, com a sequência da CDK8, pode-se predizer qual aminoácido está envolvido na fosforilação. Desta forma, a Ser182 é, possivelmente, o aminoácido que deve estar fosforilado, permitindo a atividade da CDK8. A defosforilação dos demais sítios é realizada por fosfatases e após estes processos, a CDK8 estará ativa (Fig 3) (RZYMSKI et al., 2015). 
Figura 1 - Elementos de estrutura secundária do complexo CDK8Ciclina C. Em azul, a subunidade catalítica, a CDK8, e na cor rosa, a subunidade regulatória, a ciclina $\mathrm{C}$.

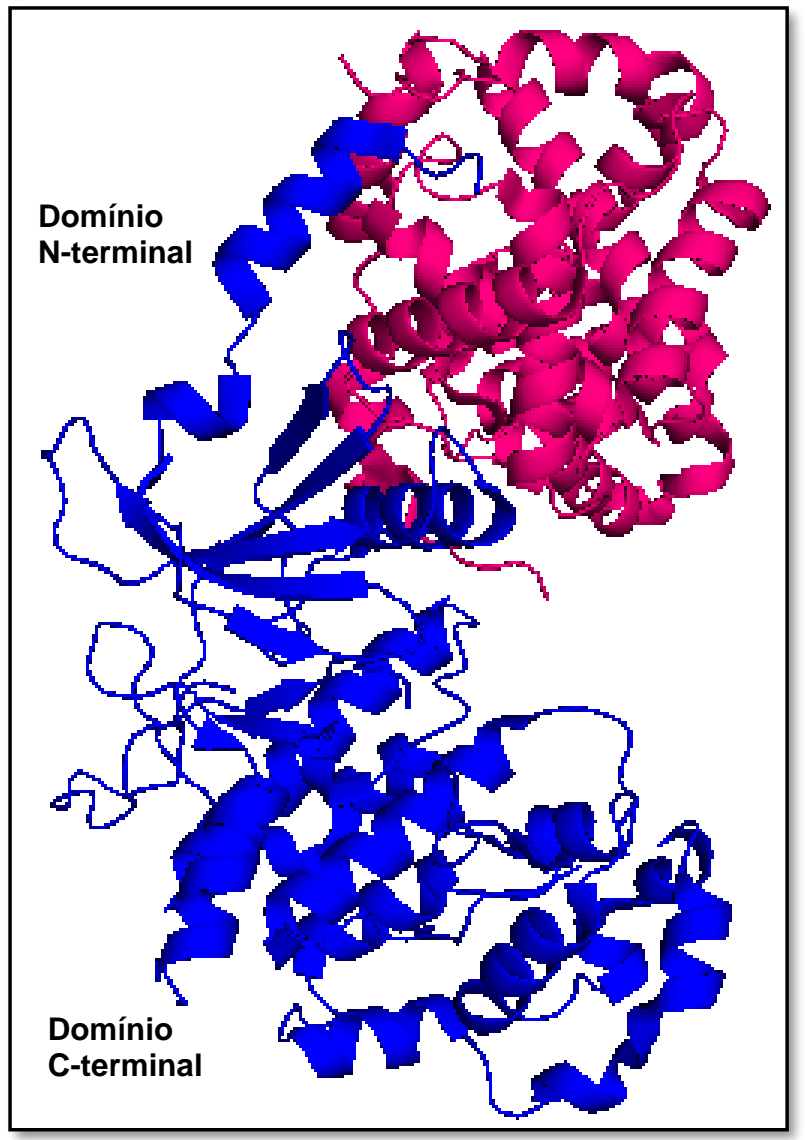

Fonte: Autoria própria. Sequência de aminoácidos da proteina CDK8 obtida do Protein Data Bank (código: 4F6U). A estrutura tridimensional foi construída com o software Pymol versão 2.1 (https://pymol.org/2/). 
Figura 2 - Reação de fosforilação do aminoácido treonina realizado pela CDK.

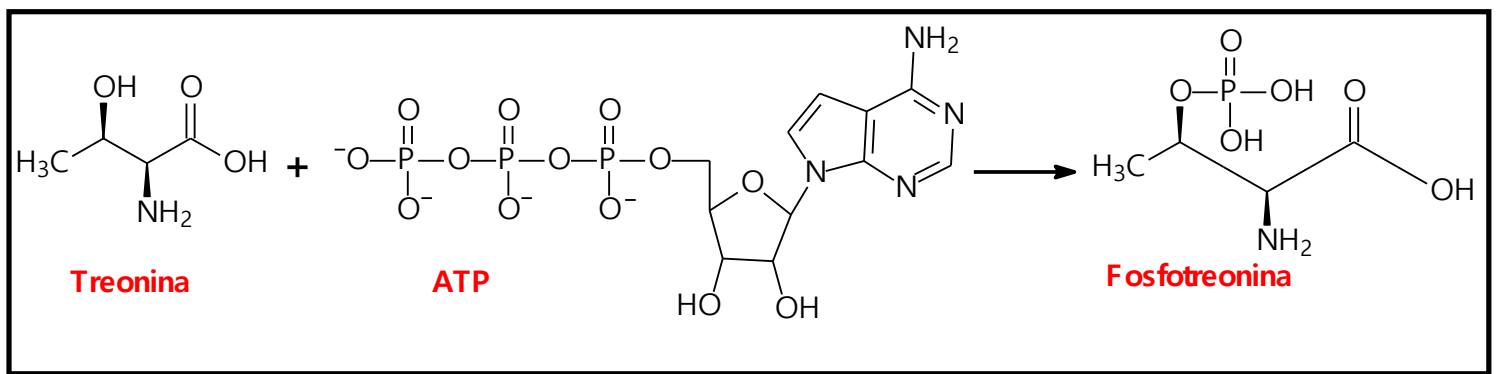

Fonte: Adaptado de Smith et al. (2011).

Figura 3 - Ativação do complexo CDK8/Ciclina C.

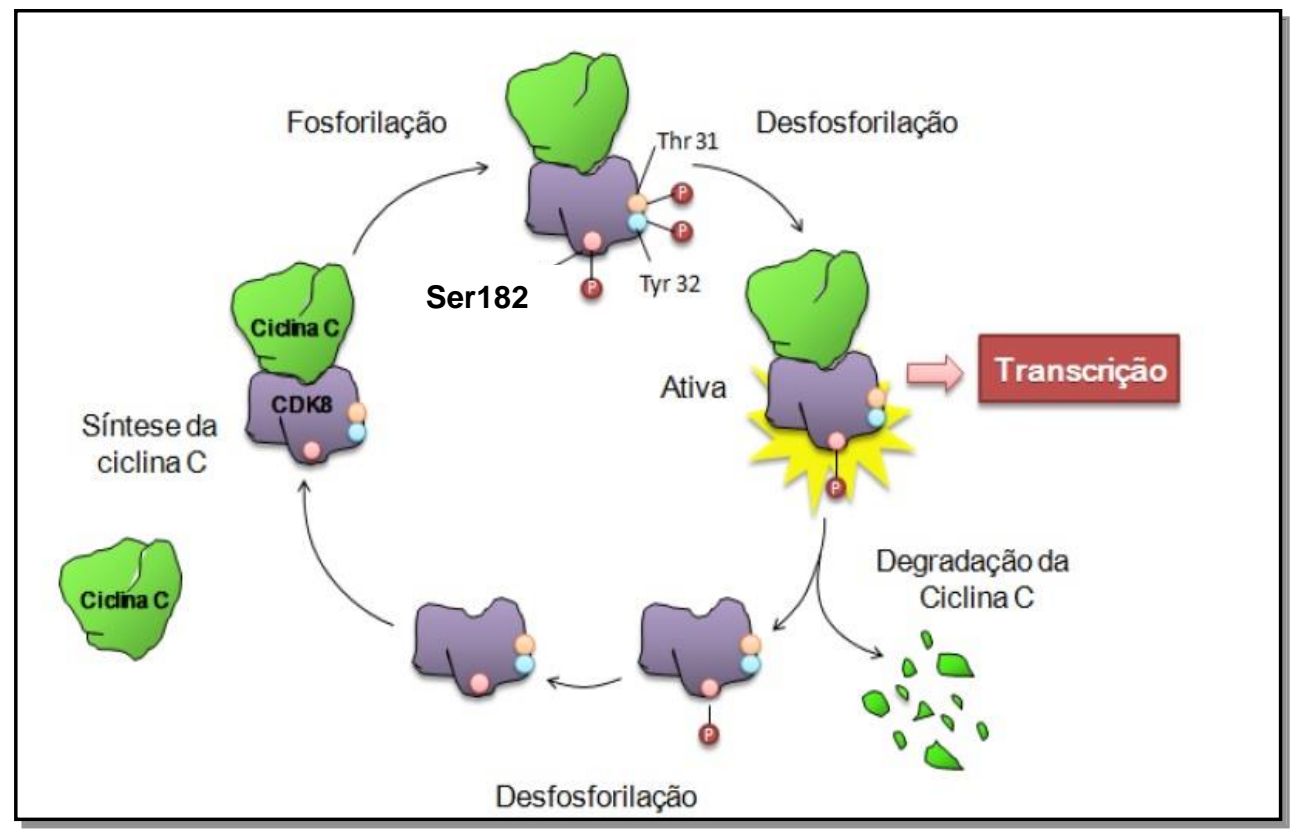

Fonte: Adaptado de Indolfo (2013).

A primeira estrutura cristalográfica da CDK8 foi determinada em 2011 (3RGF) (RZYMSKI et al., 2015), (SCHNEIDER et al., 2011). Atualmente, 26 estruturas cristalográficas foram depositadas no PDB (Protein Data Bank), pesquisa realizada em 10 de fevereiro de 2018. A estrutura de um alvo determinada experimentalmente provê informações para o desenho de drogas baseadas na estrutura ou SBBD (Structure-based Drug Design) (GREY; THOMPSON, 2011).

No que se refere à estrutura secundária, a CDK8 apresenta alta similaridade, em regiões bem conservadas, comparada às estruturas de membros da família de Quinases Dependentes de Ciclinas. A CDK8, assim como a maioria das CDKs, apresenta três resíduos de arginina (Arg50, Arg65 e Arg 178) que são bem conservados na família, como pode ser observado na Figura 4 (RZYMSKI et al., 
2015). Entretanto, algumas diferenças são encontradas além da ausência do domínio PSTAIRE, conservado entre as CDKs (Fig. 4): a primeira delas diz respeito ao motivo DMG (Asp, Met, Gly) seguido por fenilalanina ao invés de DFG (Asp, Phe, Gly) seguido de leucina, encontrado em outras CDKs (Fig. 4 e Fig 5). A segunda diferença é que a CDK8 apresenta um extenso domínio $C$-terminal, que parece estar relacionado à interação de ligantes específicos (Fig. 5). A terceira refere-se às hélices aGH1 a aGH3 em "cluster close by", ou seja, bem próximas (Fig. 5). A quarta diferença consiste na presença de nove resíduos $\left({ }^{240} E D I K T S N P Y{ }^{248}\right)$ em frente à hélice $\alpha G$ (Fig. 4 e Fig. 5). Por último, a CDK8 apresenta uma adicional hélice Nterminal $\mathrm{aB}$ que é responsável pela alta afinidade da CDK8 pela ciclina $C$ (Fig. 5) (CEE et al., 2009), (RZYMSKI et al., 2015), (SCHNEIDER et al., 2011).

Segundo Knockaert, Greegard e Meijer (2002) devido à diversidade funcional das CDKs não é surpreendente que estejam envolvidas em processos como a diferenciação celular, apoptose, transcrição e disfunção neuronal. Estes eventos celulares são mediados por diferentes CDKs, o que a torna um alvo para o desenvolvimento de inibidores. 
Figura 4 - Alinhamento da sequência de aminoácidos da CDK2 (Genbank CAA43985.1) e CDK8 (Genbank CAA59754.1). Em vermelho, na sequência da CDK2, o domínio PSTAIRE (conservado entre grande parte das CDKs, porém não observado na sequência da CDK8). Em verde, os resíduos conservados de Arginina (Arg50, Arg65 e Arg178). Em rosa, os motivos DFG, seguido de leucina (amarelo), e DMG seguido de fenilalanina (amarelo) da CDK2 e CDK8, respectivamente. Em azul, na sequência da CDK8, a inserção de nove resíduos ( ${ }^{240}$ EDIKTSNPY ${ }^{248}$ ).

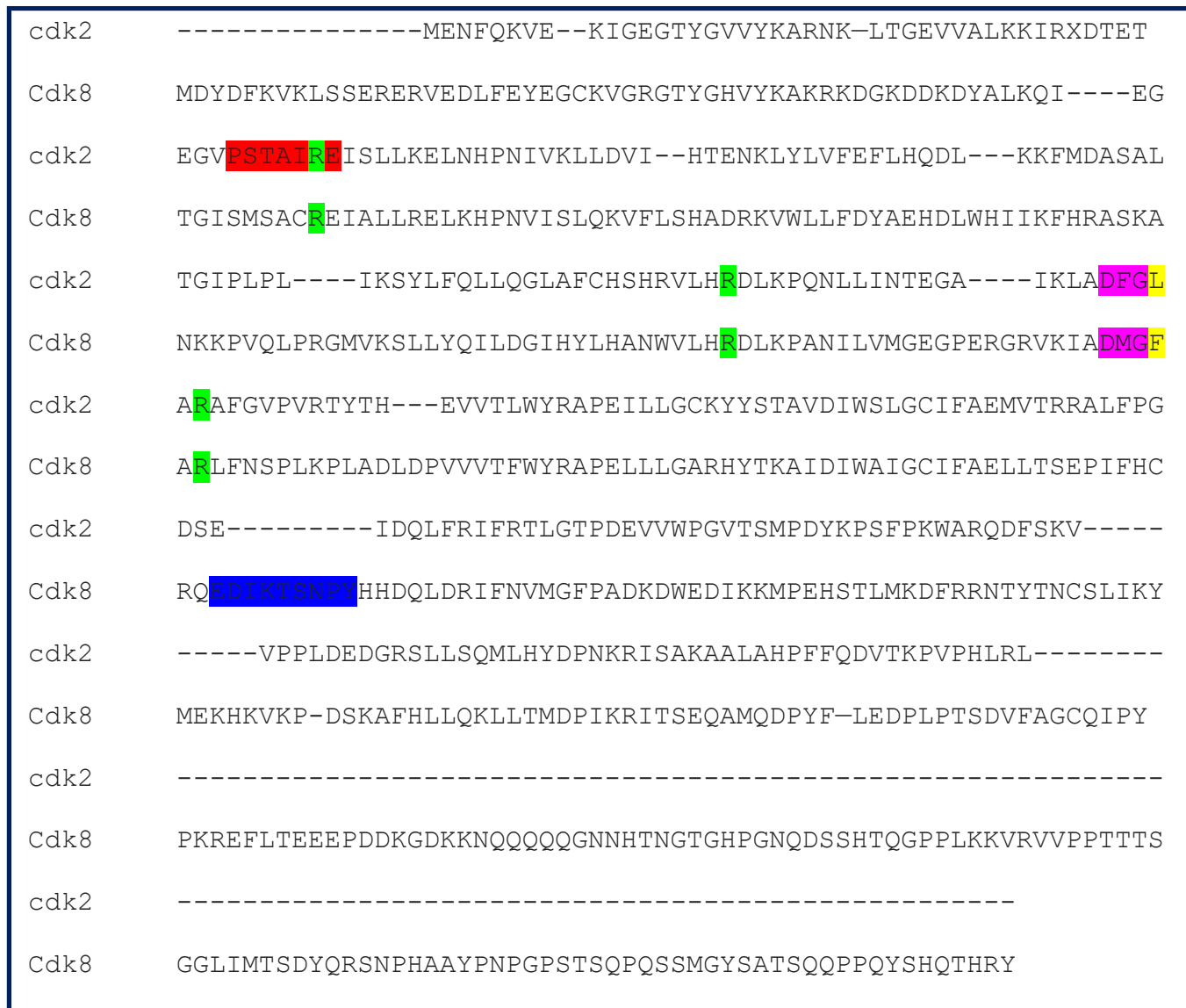

Fonte: Autoria própria. Alinhamento feito com 0 software Kalign (https://www.ebi.ac.uk/Tools/msa/kalign/). 
Figura 5 - Diferenças peculiares da Quinase Dependente de Ciclina 8 - CDK8.

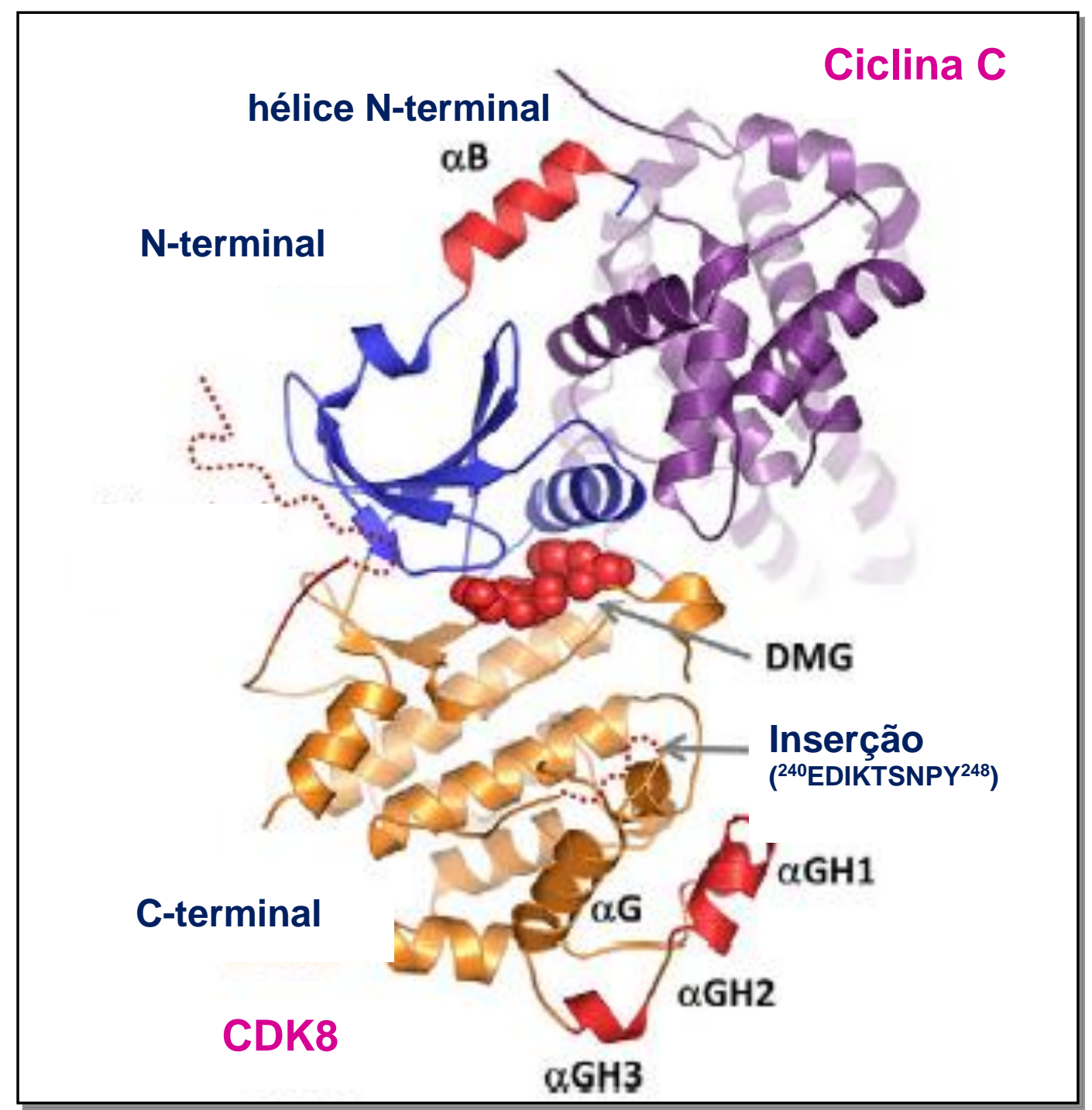

Fonte: Adaptado de Rzymski et al. (2015). 


\subsection{CDKs e o ciclo celular}

$O$ ciclo celular divide as etapas da divisão celular em quatro fases: $M, S, G_{1}$ e $\mathrm{G}_{2}$ (Fig. 6). A fase $\mathrm{S}$ corresponde à fase de síntese, onde ocorre a duplicação do DNA cromossômico. Na fase $\mathrm{M}$ ocorre a mitose, levando a separação dos cromossomos, das organelas celulares e do citoplasma. As fases de intervalo ou gap, $G_{1}$ e $G_{2}$, separam a fase $M$ da fase $S$ e a fase $S$ da fase $M$ (DEVLIN, 2011).

Uma fase que não faz parte do ciclo celular diretamente é a $\mathrm{G}_{0}$ (Fig. 6), nesta fase a célula está em equilíbrio com a fase $G_{1}$, podendo estar num estado quiescente ou senescente. Uma célula quiescente, mesmo não participando do ciclo celular, pode ser induzida a reentrar no ciclo celular ao passo que a célula senescente não pode reentrar no ciclo celular (DEVLIN, 2011).

Existem pontos de checagem (checkpoints) no ciclo celular, os quais regulam o prosseguimento para a etapa seguinte da via de divisão celular através da ação de CDKs e fosfatases. Desta forma, reações de fosforilação e defosforilação regulam as etapas do ciclo celular (ALBERTS, 2010).

Os dois checkpoints mais importantes são $\circ \mathrm{G}_{1}$, também conhecido como checkpoint de restrição ou de início do ciclo celular e o $\mathrm{G}_{2} / \mathrm{M}$ (Fig. 6). No checkpoint $\mathrm{G}_{1}$, dependendo das condições das células, as mesmas podem progredir para entrar no ciclo ou, se não atingirem as condições necessárias, permanecerão no estado quiescente, em $\mathrm{G}_{0}$, sendo $\mathrm{G}_{1}$ fortemente regulado por CDK2/Ciclina $\mathrm{E}, \mathrm{CDK} 4 / \mathrm{Ciclina}$ D e CDK6/Ciclina D (SKOTHEIM et al., 2008).

No checkpoint $G_{2} / M$, conhecido como ponto de verificação de danos do DNA, assegura que a célula foi submetida a todas as alterações necessárias durante as fases $\mathrm{S}$ e $\mathrm{G}_{2}$ e está pronta para dividir. Este checkpoint é fortemente regulado por CDK2/Ciclina B. De leveduras para humanos, a progressão do ciclo celular é dirigida pela atividade de CDKs (GUARDAVACCARO; PAGANO, 2006). 
Figura 6 - Fases do ciclo de divisão celular e checkpoints.

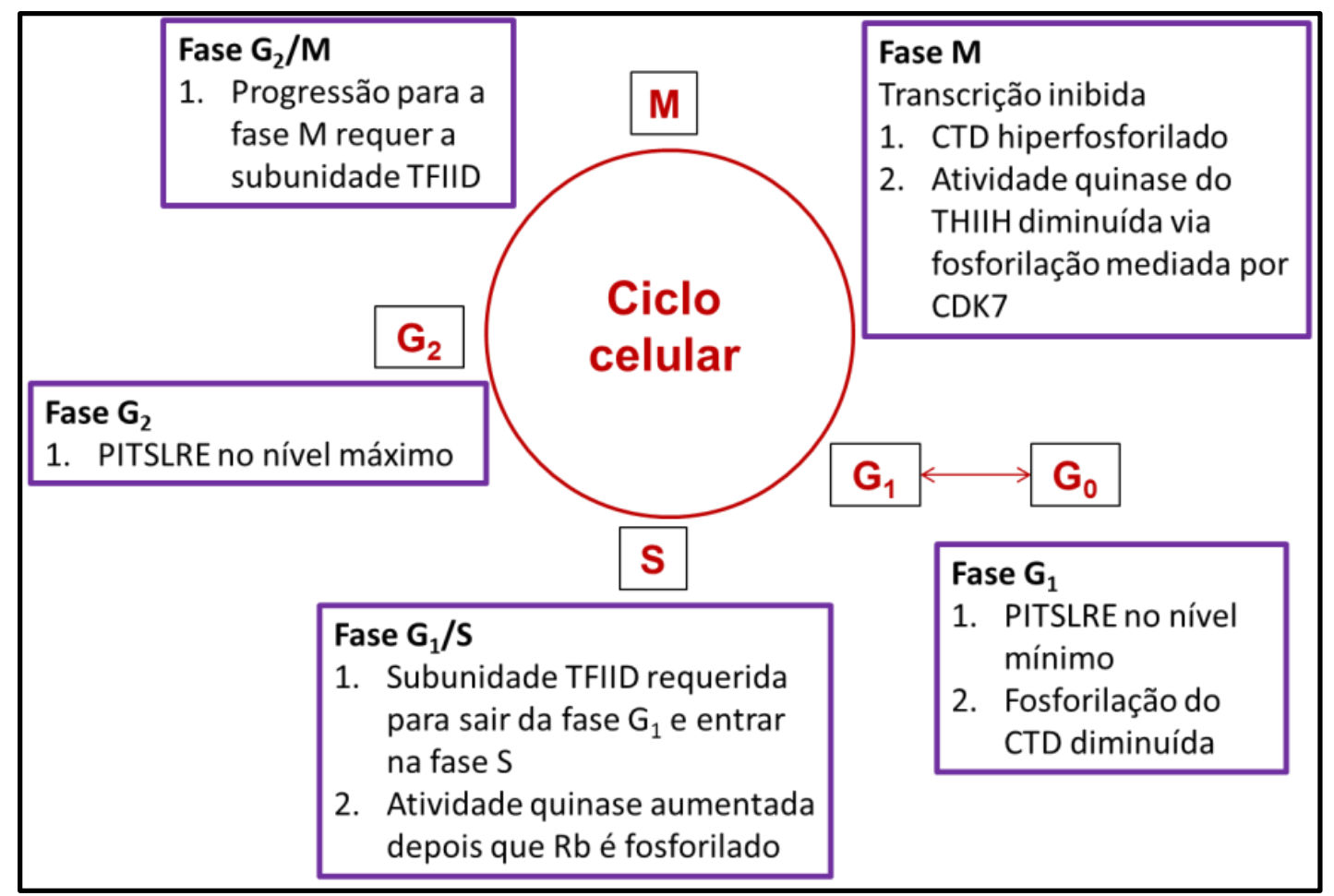

Fonte: Adaptado de Bregman, Pestel e Kidd (2000).

As CDKs mudam para uma conformação ativa quando ligadas a proteínas ciclinas. Esta interação ocorre, por exemplo, entre as fases G1, S, G2 e M do ciclo celular (MEIJER; RAYMOND, 2003). Qualquer disfunção na regulação do ciclo celular pode levar, dentre outras doenças, ao câncer.

A regulação do ciclo celular é mais dependente da concentração de CDKls (Cyclin Dependent Kinase Inhibitors - inibidores de CDK) endógenos e ciclinas do que propriamente da presença de CDKs (LEITCH; HASLETT; ROSSI, 2009). Estas quinases são reguladas por uma variedade de mecanismos, incluindo eventos de fosforilação, associação com proteínas inibitórias e proteínas de degradação (MORGAN, 1997).

Durante a fase $G_{1}$ do ciclo celular, as células podem progredir para replicar o DNA, ou deixar o ciclo celular, entrando num estado fisiológico conhecido como Go, permanecendo com baixa atividade transcricional. Mas a fase $\mathrm{G}_{0}$ é transitória e as células podem reentrar no ciclo celular, quando fatores de crescimento e nutrientes estão disponíveis. Na maioria dos cânceres humanos, não há um controle entre a progressão do ciclo celular e a saída do mesmo (HANAHAN; WEINBERG, 2000). 
Como em $\mathrm{G}_{0}$ há baixa atividade transcricional, repressores transcricionais devem estar ativos nesta fase.

Vários estudos sugerem que fatores de transcrição E2F fazem parte da maquinaria celular que controla a transição $\mathrm{G}_{0} / \mathrm{G}_{1}$, particularmente, complexos de E2F4 associados a histonas deacetiladas podem reprimir a expressão de genes em Go (TAKAHASHI; RAYMAN; DINLACHT, 2000), (TRIMARCHI; LEES, 2002). Evidências mostram que os fatores E2F são regulados por genes Rb (genes supressores de tumor retinoblastoma). A perda da função do gene Rb é suficiente para que a célula entre no ciclo celular (SAGE et al., 2003).

$\mathrm{Na}$ transição $G_{1} / S$, fatores $R b$ são inativados por reações de fosforilação sucessivas efetuadas por CDK4/Ciclina D e CDK2/Ciclina E. No entanto, estas quinases estão ausentes em Go. Em 2004, Ren e Roolings (2004) relataram que esta atividade quinase seria fornecida pelo complexo CDK3/Ciclina $C$. A ciclina $C$ forma um complexo com a proteína $R b$, uma vez que fosforila $R b$ em $G_{0}$.

Até meados de 2003, a única quinase conhecida associada com a ciclina $C$ era a CDK8. Este importante complexo $C D K 8 / C i c l i n a ~ C$ está associado à regulação da RNA Polimerase II e ao processo de transcrição e não está relacionado à fosforilação de $\mathrm{Rb}$. Entretanto, a quinase associada à ciclina $\mathrm{C}$ e que fosforila $\mathrm{Rb} \mathrm{em}$ Go é a CDK3, outra quinase dependente de ciclina (MEYERSON et al., 2002).

A CDK11, outro membro da superfamília CDK, liga a forma hiperfosforilada do CTD, assim como a Caseína Quinase II (CKII), uma quinase necessária para a progressão do ciclo celular. A atividade de CKII é requerida na fase $\mathrm{G}_{1}$ do ciclo celular. Adicionalmente, os níveis da proteína CDK9 aumentam durante o ciclo celular, com o nível máximo em $\mathrm{G}_{2} / \mathrm{M}$ e mínimo em $\mathrm{G}_{1}$. $\mathrm{O}$ nível de fosforilação do CTD também muda no decorrer do ciclo celular, sendo mais alto em $S, G_{2}$ e $M$ do que na fase G1 (BREGMAN; PESTEL, KIDD, 2000).

O fator geral de transcrição TFIID, que compreende a proteína de ligação no "TATA box" (sequência promotora do DNA onde inicia a transcrição) e vários outros fatores associados foram também relacionados à regulação do ciclo celular (Fig. 5) (BREGMAN; PESTEL; KIDD, 2000).

A CDK8 possui uma relação consideravelmente importante com as vias de sinalização celular, tanto durante a progressão do ciclo celular controlada quanto na progressão do câncer (SZILAGYI; GUSTAFSSON, 2013). Esta quinase regula, por exemplo, o gene p21, que também é regulado pela p53 durante estresse genotóxico, 
que leva à parada do ciclo celular e à apoptose (REINHARDT; SCHUMACHER, 2012) (Fig.7). A inibição da CDK8 diminui a transcrição de p21, enquanto que a superexpressão da CDK8 estimula a transcrição de p21, sugerindo, desta forma, que a CDK8 estimula a via p53-p21 e inibe o ponto de restrição celular (Fig. 7). Segundo Porter et al., (2012), a proteína p21 interage diretamente com a proteína CDK8 e estimula a sua atividade quinase, apresentando consideráveis consequências para a biologia do câncer (SZILAGYI; GUSTAFSSON, 2013).

$A$ via de sinalização Wnt/ß-catenina, também regulada pela CDK8, promove à progressão do ciclo celular ou entrada na fase S (Fig. 7). A CDK8, neste caso, é considerada como potencial oncogene uma vez que estimula a $\beta$-catenina durante a transcrição (NIEHRS; ACEBRON, 2012), (TALLURI; DICK, 2012). Um gene alvo da $\beta$-catenina é o c-Myc, que se liga a CDK8, resultando no controle direto de genes $\beta$ catenina (Fig. 7). O fator de transcrição E2F também afeta a transcrição de c-Myc, atuando como um promotor do ciclo celular para a fase S (Fig. 7), no entanto, degrada a $\beta$-catenina e seus genes-alvo. O fator E2F, portanto, além de controlar a via de sinalização Wnt/ $\beta$-catenina, pode induzir a célula à apoptose (WONG et al., 2011).

Figura 7 - Fase do ciclo celular regulada pela CDK8.

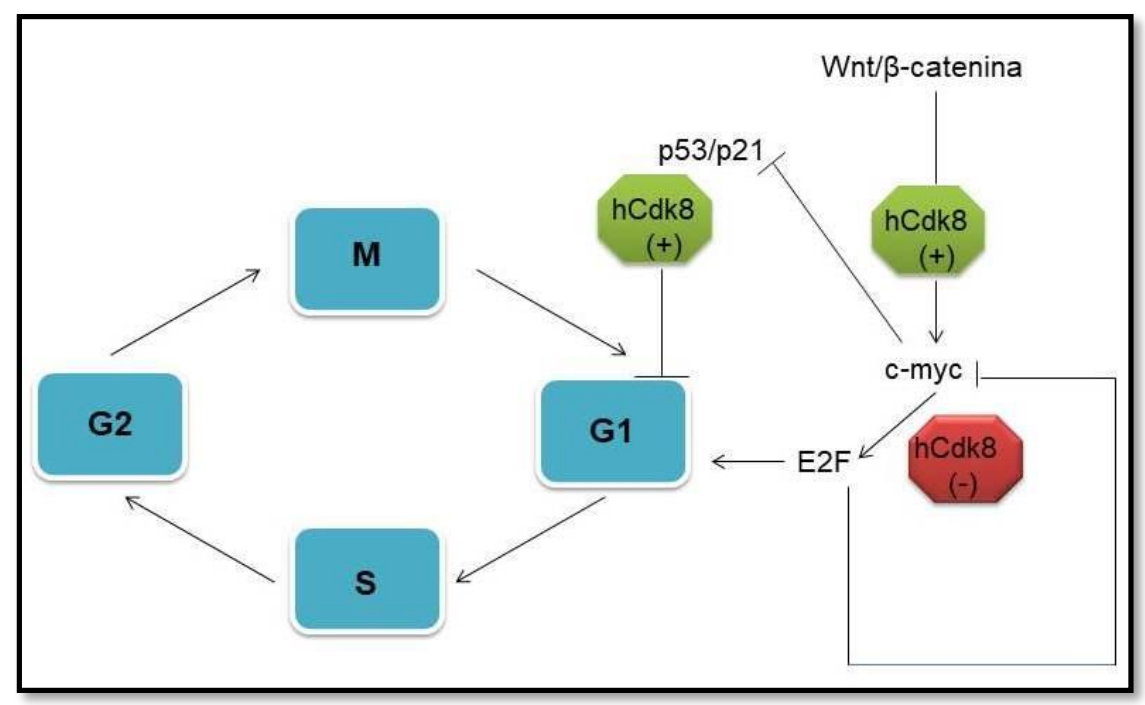

Fonte: Adaptado de Szilagyi e Gustafsson (2013).

\subsection{CDK8 e o controle da transcrição}

A transcrição é o processo pelo qual cadeias de RNA são sintetizadas a partir de moldes de DNA (Figura 8). As enzimas que catalisam este processo são as RNA 
polimerases (Figura 9). Diferentemente das DNA polimerases, as RNA polimerases não requerem um iniciador (primer). A RNA polimerase II (RNA Pol II) é a responsável pela síntese de RNAm no núcleo (DEVLIN, 2011). A Figura 9 mostra a estrutura cristalina da RNA Pol II no complexo transcricional durante a transcrição. A dupla hélice de DNA é vista entrando na fenda principal da enzima e desenrolando antes do sítio ativo (GNATT et al., 2001).

Para transcrever um gene, a RNA-polimerase passa por etapas bem definidas, agrupadas em três fases: a iniciação, o alongamento e a terminação (Fig. 10). Os padrões de fosforilação, catalisada por CDKs, do domínio carboxi-terminal da RNA Pol II determinam quais fatores transcricionais se associam à polimerase. A RNA Pol II (cinza), na Figura 10, é representada em quatro posições ao longo do gene e em cada posição, seu CTD é representado por uma cor diferente para indicar diferentes estados de fosforilação. $\mathrm{Na}$ fase de iniciação da transcrição, um promotor (sequência de DNA à qual a RNA-polimerase é inicialmente ligada) forma com a polimerase um complexo promotor-polimerase que sofre modificações estruturais necessárias à continuação da transcrição. Durante o alongamento, a polimerase, além de catalisar a síntese de RNA, realiza funções de reparo. Após a transcrição de toda a extensão do gene, a polimerase precisa parar e liberar o RNA transcrito. Esta fase é a terminação (PHATNANI; GREENLEAF, 2006), (WATSON et al., 2015).

Figura 8 - Transcrição do DNA.

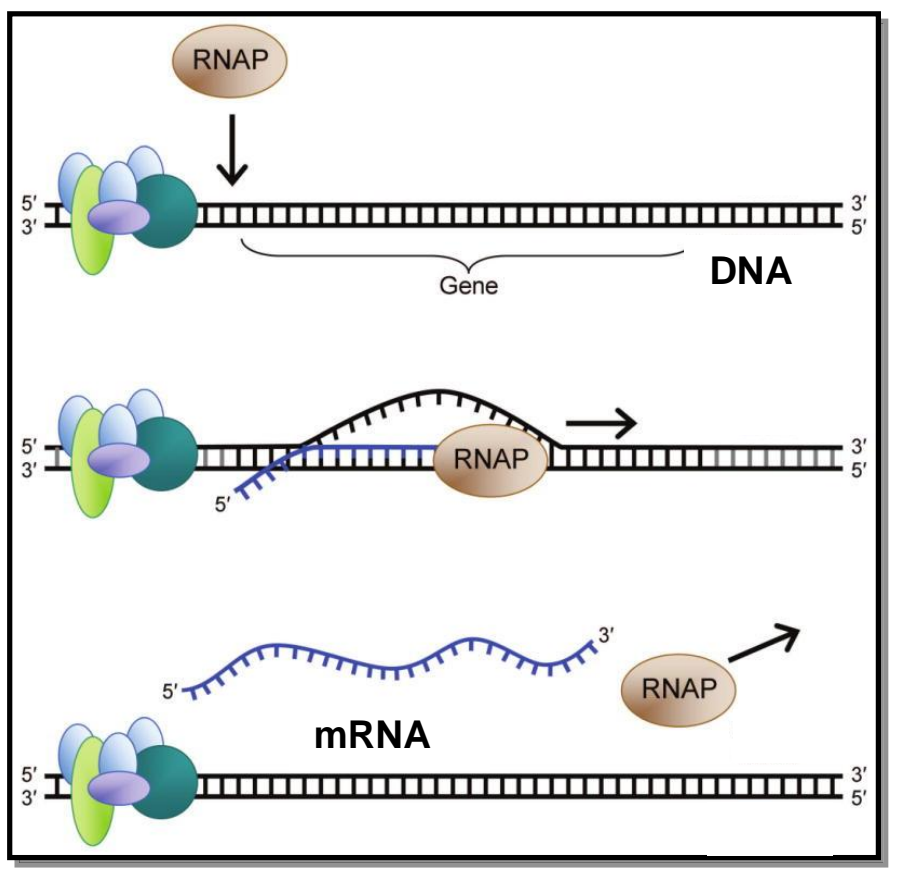

Fonte: Adaptado de Body et al. (2009). 
Figura 9 - Estrutura cristalina da RNA-Polimerase II durante a transcrição. $\mathrm{Na}$ cor laranja, está representada a dupla hélice de DNA.

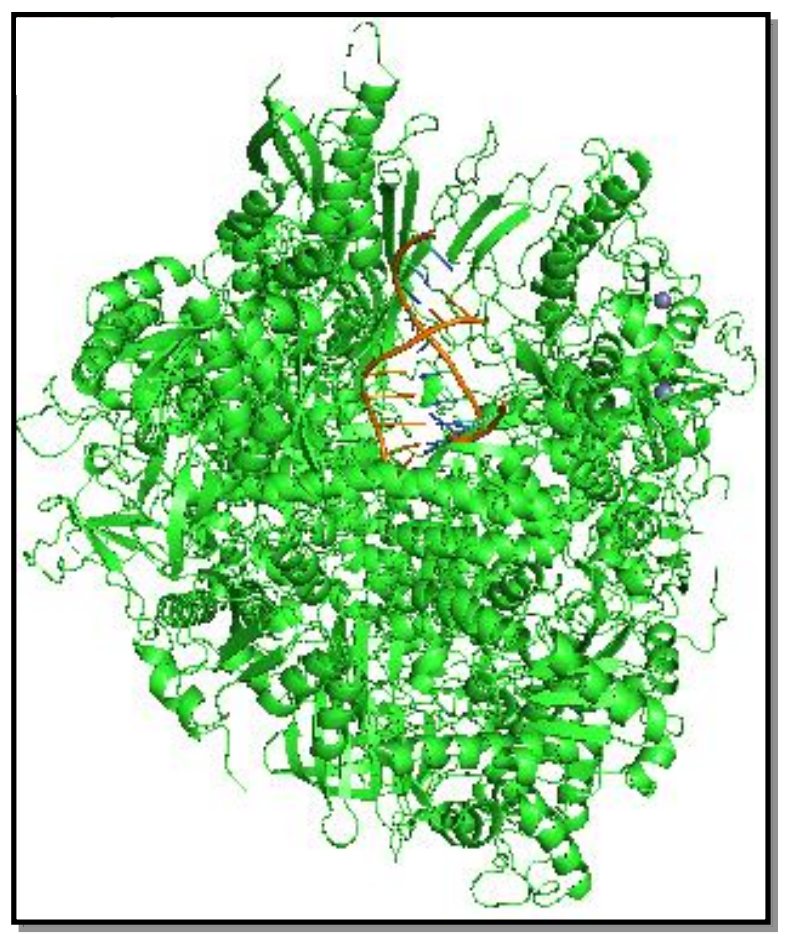

Autoria própria. Sequência de aminoácidos da RNA Polimerase II obtida do Protein Data Bank (código: $116 \mathrm{H}$ ) e renderizada com o auxílio do software Pymol versão 2.1 (https://pymol.org/2/).

Figura 10 - Fases da transcrição (iniciação, alongamento e terminação) e os diferentes padrões de fosforilação do CTD da RNA Pol II. O CTD (linha ondulada) é representado por cores diferentes (diferentes padrões de fosforilação) em cada etapa da transcrição. Diferentes padrões de fosforilação significam que diferentes fatores de transcrição (TFIIH, PTEFb e PPase) se ligam à RNA Pol Il em fases distintas do processo transcricional.

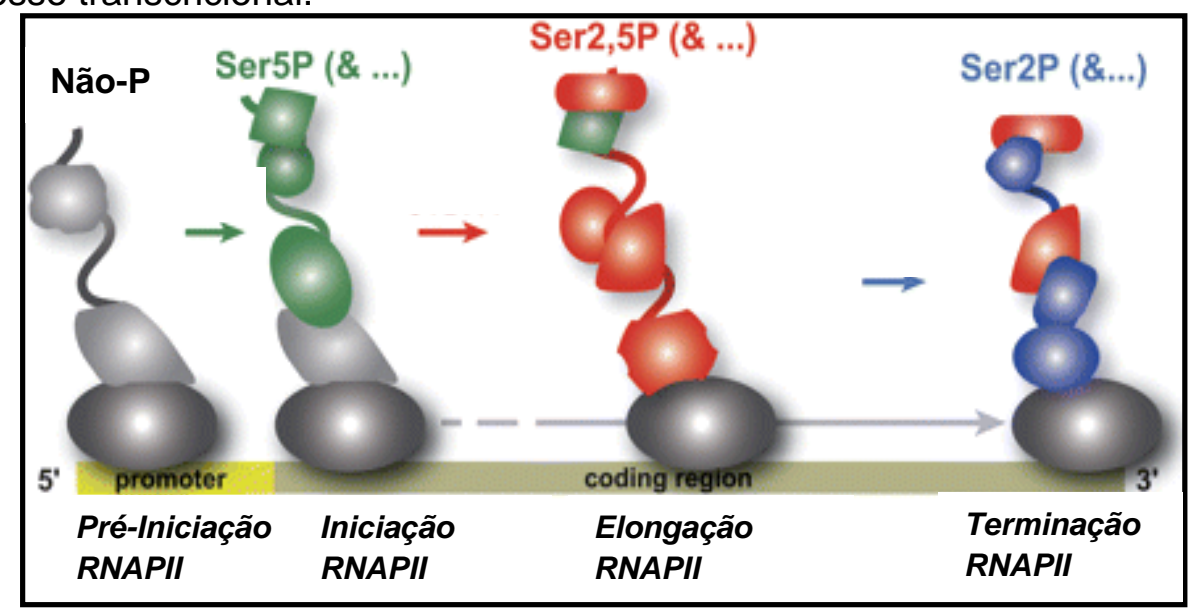

Fonte: Adaptado de Phatnani e Greenleaf (2006). 
Enquanto nas bactérias é necessário apenas um fator de iniciação, nos eucariotos são necessários vários fatores para uma iniciação eficiente. Esses fatores são chamados Fatores Gerais de Transcrição (GTFs, general transcription factors). No entanto, como nos eucariotos o DNA molde está incorporado nos nucleossomos, além de GTFs são necessárias também outras proteínas que fazem parte do chamado complexo mediador, proteínas reguladoras de ligação ao DNA e enzimas modificadoras de cromatina (WATSON et al., 2015).

Em eucariotos, a RNA Pol II não é capaz de realizar a síntese do RNAm sozinha, necessitando de cinco fatores transcricionais (TFIIB, TFIID, TFIIE, TFIIF e TFIIH) que formam um complexo de pré-iniciação sobre o promotor a fim de realizar a transcrição acurada e uma fase de elongação estável (ORPHANIDES; REINBERG, 2002). Vários ativadores transcricionais, cofatores, mediadores, histonas modificadoras de enzimas e fatores remodeladores de cromatina são conhecidos por auxiliarem nas etapas de transcrição. Um destes, o complexo mediador, foi descoberto pela primeira vez, na levedura Saccharomyces cerevisae, onde seus produtos gênicos suprimem os defeitos causados pela deleção do domínio C-terminal (CTD) (FURUMOTO et al., 2007).

O complexo mediador de leveduras foi purificado por Kornberg e outros colaboradores em 1994. Este complexo apresenta mais de 20 subunidades, contendo 9 proteínas Med (Med 1-Med4, Med6-Med8, Med10 e Med11) e cinco outras subunidades (Gal11, Rgr1, Nut1, Sin4 e Rox3), além de um conjunto de proteínas SRB (Srb2 e Srb4-11). Recentemente, uma nova nomenclatura para todas as subunidades mediadoras inclui 34 proteínas Med (MED1-31, MED1L, MED12L e MED13L), bem como a CDK8 e ciclina C (BOURBON; AGUILERA; ANSARI, 2004), (KIM et al., 1994).

Para regular a ativação transcricional este complexo interfere tanto na transcrição basal quanto na fosforilação do domínio carboxi-terminal da subunidade maior da RNA Pol II. Os complexos mediadores podem ou não conter o módulo MED12-MED13-CDK8-CiclinaC (MALIK; ROEDER, 2005).

Estudos demonstram que existem várias estruturas e conformações, sendo que o maior complexo mediador, em Saccharomyces cerevisae e em humanos consiste de três módulos: cabeça, meio e cauda. Embora a composição do módulo seja bem conservada em leveduras e humanos, o complexo mediador sofre 
mudanças conformacionais, devido à ligação de diferentes ativadores e à RNA Pol II (TAATJES et al., 2002).

Em eucariotos superiores, existem três complexos CDK/Ciclina que contêm fatores de transcrição. O fator transcricional geral TFIIH contém CDK7/Ciclina $\mathrm{H}, \mathrm{o}$ TRAP/Complexo mediador contém a CDK8/Ciclina C e o fator transcricional de elongação PTEFb contém a CDK9/CiclinaT1. Todos estes fosforilam o domínio carboxi-terminal da RNA Pol II. Assim, regulam a função da RNA Pol II em etapas importantes da transcrição, bem como nas etapas posteriores da expressão gênica (ORPHANIDES; REINBERG, 2002). Segundo Knuesel et al., (2009), em células humanas, 30\% do subcomplexo CDK8 existe de forma independente do mediador e fosforila não apenas o domínio CTD da pol II, mas também a histona H3, Med 13 e a própria CDK8.

A CDK8 é considerada um regulador positivo e negativo do processo transcricional. Fryer, White e Jones relataram que a CDK8 regula a atividade de uma proteína transmembrana ativadora conhecida como Notch ICD. Esta sofre proteólise após ativação levando à produção de um peptídeo truncado, que age como um ativador transcricional no núcleo. Fryer, White e Jones revelaram ainda que a proteína MAM, requerida para a ativação transcricional da ICD, interage com a CDK8 facilitando a fosforilação da proteína ativadora ICD (NEMET et al., 2014). A CDK8 é responsável por fosforilar o interdomínio da proteína SMAD, reguladora transcricional. Esta fosforilação é necessária, não somente para uma ativação transcricional completa, mas também para degradar o ativador (ALARCON et al., 2009).

A CDK8 pode regular positivamente a etapa de elongação via RNA Polimerase II, uma vez que a mesma recruta o Complexo de Super Elongação (SEC - Super Complex Elongation) e pTEF-b. A função do fator transcricional HIF1A, neste caso, é facilitar o recrutamento do complexo mediador-CDK8 para genes que induzem a hipóxia via interação de transativação do fator HIF1A com o mediadorCDK8 (GALBRAITH et al., 2013). Bancerek et al., (2013) relataram o papel da CDK8 em resposta ao interferon- $\gamma$. A quinase fosforila o ativador transcricional STAT1 no resíduo S727, regulando a transcrição especificamente.

Akoulitchev, Chuikov e Reinberg (2000) mostraram que o complexo CDK8 pode fosforilar a ciclina $\mathrm{H}$ e esta fosforilação impede a atividade transcricional do $\mathrm{TFIIH}$, atuando desta forma como regulador transcricional negativo. Zhao et al., 
(2012) demonstraram que a CDK8 atua como regulador negativo da lipogênese em células de insetos e mamíferos, uma vez que fosforila o fator SREBP-1c, num resíduo conservado de treonina.

A subunidade maior da RNA Pol II possui um domínio C-terminal (CTD) que se prolonga como uma "cauda". O CTD contém uma série de repetições da sequência heptapeptídica Tyr-Ser-Pro-Thr-Ser-Pro-Ser. Cada repetição contém sítios de fosforilação por quinases específicas. A forma inicial da RNA Pol II contém uma "cauda" não fosforilada, contudo, a cauda encontrada na fase de alongamento possui vários grupos fosfato. A adição desses grupos auxilia na liberação da polimerase da maioria dos fatores gerais de transcrição (WATSON et al., 2015).

Segundo Bregman, Pestell e Kidd (2000), o ciclo celular e o processo de transcrição realizado pela RNA Pol II estão intimamente relacionados, uma vez que ambos utilizam componentes compartilhados. A atividade transcricional da RNA Pol II é modulada durante o ciclo celular por algumas CDKs, incluindo a CDK1, CDK7, CDK8 e CDK9. Estas CDKs estão relacionadas com a fosforilação do CTD da RNA Pol II. A fosforilação deste domínio é essencial para vários eventos pós-iniciação durante a síntese de RNAm em todos os eucariotos (KOBOR; GREENBLATT, 2002), (PALANCADE; BENSAUD, 2003). As CDKs 1, 7, 8 e 9 são bioquimicamente e funcionalmente distintas (RAMANATHAN et al., 2001), (RICKERT; CORDEN; LEES, 1999) e executam funções não-redundantes no processo transcricional (KOBOR; GREENBLATT, 2002).

As mudanças que ocorrem no ciclo celular dependem do estado de fosforilação do CTD da subunidade maior da RNA Pol II. Desse modo, o bloqueio dos complexos da RNA Pol Il e danos no DNA estimulam o acúmulo da p53, uma proteína que estimula a apoptose de células danificadas, ou impede a célula de se dividir.

O gene supressor de tumor p53 regula vários outros genes importantes para o controle do crescimento celular. Donner et al., (2007) relataram que a coativação do p53 depende da ativação do gene p21. O recrutamento da CDK8 para o promotor p21 relaciona-se com a ativação da transcrição, sendo um marcador celular para danos do DNA e controle da senescência. (DONNER et al., 2007), (NEMET et al., 2014). 


\subsection{CDKs e o câncer}

A promoção do ciclo de divisão celular e a resistência à morte celular programada ou apoptose são fatores críticos de uma célula cancerígena. Os genes que codificam proteínas que estimulam a divisão celular ou que promovem resistência à apoptose são denominados protooncogenes. Mutações ativadoras em um protooncogene o convertem em um oncogene (DEVLIN, 2011).

Lee Hartwell, Tim Hunt e Paul Nurse descobriram as CDKs e ciclinas como reguladores da maquinaria do ciclo celular. Numa célula cancerígena frequentemente são encontradas alterações genéticas em ciclinas, CDKs e inibidores de CDKs que levam à proliferação descontrolada de células tumorais (RZYMSKI et al., 2015).

O complexo transcricional CDK8/Ciclina C suprime a transcrição diretamente através da fosforilação da RNA Pol II, em leveduras e indiretamente, pela fosforilação da ciclina humana H (Cyc H) (AKOULITCHEV; CHUIKOU; REINBERG, 2000), (HENGARTNER et al., 1988). Não obstante, a CDK8 foi reportada como regulador transcricional positivo, implicando em efeitos oncogênicos, sendo identificada como potencial oncogene para o câncer de cólon. A transcrição do fator E2F1reprime a atividade beta-catenina, além disso, a ativação do domínio de E2F1 faz com que ocorra interação com a CDK8, sendo a função quinase essencial para inibir o efeito de E2F1 sobre a atividade beta-catenina. Então com base nos estudos de Morris e Firestein, a CDK8 atua como um oncogene identificado em 2008 (FIRESTEIN et al., 2008), (FIRESTEIN; HAHN, 2009), (MORRIS et al., 2008), (NEMET et al., 2014).

No último censo realizado pela Organização Mundial de Saúde (OMS), 2004, o câncer de mama ficou entre as dez principais causas de óbito em mulheres entre 15 e 44 anos de idade, nos países de média e alta renda. Aproximadamente $70 \%$ de todos os cânceres de mama expressam o receptor de a estrogênio ERa (Estrogen Receptor) que participa dos processos biológicos como um fator transcricional que dirige a proliferação de células de câncer de mama. Atualmente, o principal tratamento para o câncer de mama envolve a terapia hormonal com, por exemplo, o conhecido tamoxifeno que suprime a síntese de estrogênio, porém ao longo do tratamento, os pacientes desenvolvem resistência a este medicamento. Em 2017, Mc Dermott et al., (2017) relataram o uso de inibidores de CDK8 e sua isoforma, 
CDK19, como alternativa para o tratamento do câncer de mama uma vez que a inibição suprime a transcrição de receptores de estrogênio, diminuindo a proliferação de células de câncer de mama.

A CDK8 foi relacionada também a fatores epigenéticos, que são fatores que alteram o DNA sem modificações da sequência (KAPOOR et al., 2010). Em suma, essas descobertas a colocam como alvo de drogas em pesquisas relacionadas ao câncer. Entretanto, o desenvolvimento de inibidores seletivos tem sido difícil, uma vez que a topologia do sítio de ligação ao ATP é muito bem conservada para grande parte das CDKs, permitindo a ligação de inibidores ATP-competitivos tipo I (ECHALIER; ENDICOTT; NOBLE, 2010). Estes inibidores de primeira geração servem como modelo para o design racional de drogas de segunda geração que ligam no sítio de ligação ao ATP (PEYRESSATRE et al., 2015).

Recentemente, estratégias alternativas visam ao desenvolvimento de inibidores direcionados a regiões distintas do sítio de ligação ao ATP que oferecem maior seletividade. A lista de inibidores de CDKs inclui compostos naturais, sintéticos ATP-competitivos e ATP-não competitivos com diferentes estruturas químicas, bem como peptídeos e peptimiméticos (PEYRESSATRE et al., 2015).

A Figura 11 mostra os diferentes modos de ação de inibidores de CDKs. No caso de inibidores ATP competitivos (Fig. 11A), o composto se liga exatamente no sítio de ligação ao ATP, com interações semelhantes as do ATP no sítio ativo, impedindo desta forma a ligação do ATP. Os peptídeos podem ligar na subunidade regulatória propriamente dita, na ciclina ou na interface CDK-ciclina, alterando a função da mesma (Fig. 11B). Dentre os inibidores ATP não-competitivos estão os compostos que se ligam próximo ao sítio catalítico, permitindo que o substrato se ligue a CDK, porém não ocorre nenhuma reação. Mais recentemente, foi relatado o mecanismo de inibição alostérica de CDKs em que o inibidor se liga a um sítio alostérico que é diferente do sítio catalítico e pode impedir ou a ligação do substrato ou a ligação do ATP à CDK (PEYRESSATRE et al., 2015). 
Figura 11 - Estratégias de inibição de CDKs.

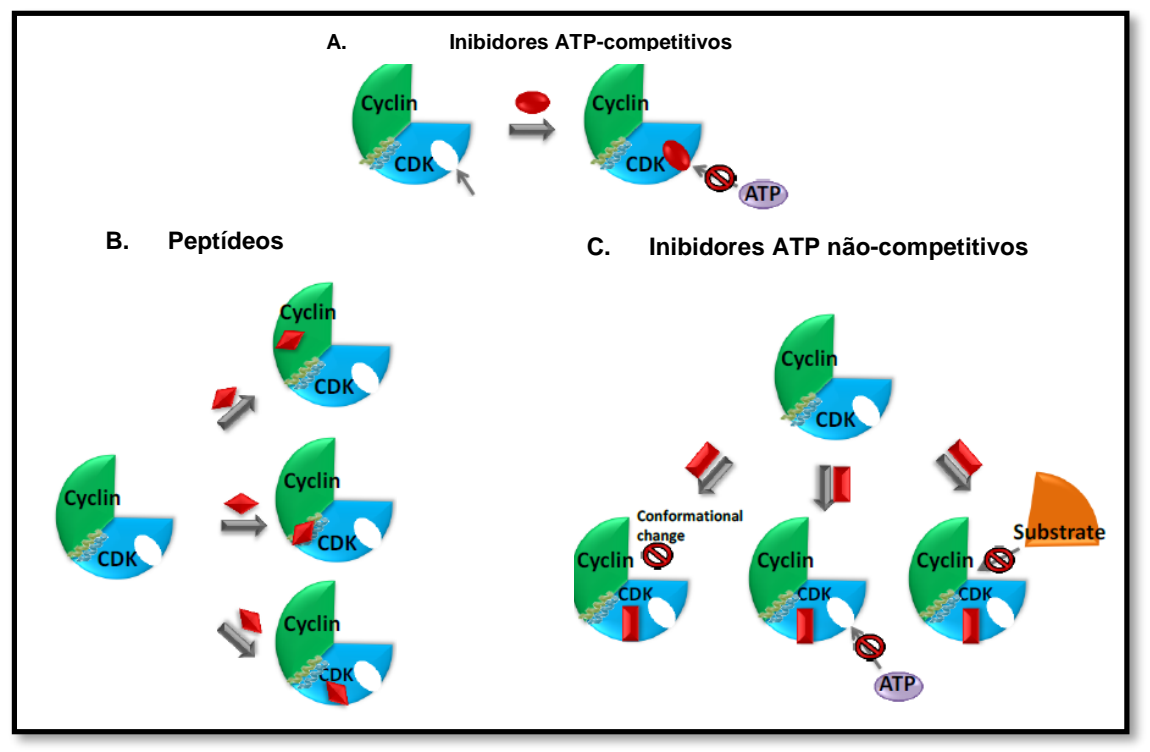

Fonte: Adaptado de Peyressatre et al. (2015).

\subsection{Inibidores de CDKs naturais e seus análogos}

Os inibidores de CDKs podem ser divididos em duas categorias genéricas: a primeira categoria inclui as proteínas inibidoras de CDKs ou CKIs (Cyclin Dependent Kinase Inhibitors) e a segunda, pequenas moléculas de inibidores.

Os mecanismos de inibição de CDKs são baseados nas principais interações que ocorrem no sítio de ligação ao ATP incluindo as ligações de hidrogênio entre Leu 83 a N1, Glu 81 a N(6)H2 e Asp 86 a O(2)H e interação do grupo fosfato com o sítio de ligação envolvendo os resíduos Lys-33, Asn-132, Asp-145, Lys-129, Thr-14 e Wat-558 (SHARMA; SHARMA; TYAGI, 2008), (SIELECKI et al., 2000).

Sharma, Sharma e Tyagi (2008) publicaram as principais classes de inibidores de CDKs que incluem compostos naturais e pequenas moléculas sintéticas, além de proteínas inibidoras de CDKs. Dentre as classes de inibidores podem ser citadas as estauporinas e seus análogos, flavonoides e seus derivados, derivados de purina, derivados indólicos, derivados de piridina e pirimidinas, derivados de indirubina, derivados de pirazol, tiazol, himenialdiasina e seus análogos. Enfatizaremos aqui os inibidores naturais e seus análogos (Fig. 12).

A estausporina (1) é um produto natural, mas propriamente, um alcaloide, que contém na sua estrutura o bis-indol (PEYRESSATRE et al., 2015). Isolada da bactéria Streptomyces staurosporeus, a estausporina (1) inibiu CDK2/ciclina A (IC50 
$=0,007 \mu \mathrm{M})$ e CDK4/ciclina $\mathrm{D}\left(\mathrm{IC}_{50}=3-10 \mu \mathrm{M}\right)$. O composto 1 inibiu também o crescimento de linhagens de células de glioma humano (FURUSAKI et al., 1982), (HARMALKAR; SHIRSAT, 2006), (MEIJER, 1995),. O análogo 7-hidroxiestausporina (2) isolado de Streptomyces sp apresentou boa atividade frente a PKC (Protein Kinase C) e CDKs (IC50 PKC $\left.=0,0068 \mu \mathrm{M}, \mathrm{CDK}_{1}=0,031 \mu \mathrm{M}, \mathrm{CDK} 2=0,03 \mu \mathrm{M}\right)$ (SENDEROWICZ, 2005). O derivado da estausporina furanosilado (3), conforme Chin et al., (1999) inibiu o crescimento celular e estimulou a apoptose. A quercetina (4) é um flavonoide presente em plantas bioativas que mostrou inibir células tumorais, apesar de ser considerado um inibidor fraco de CDKs (KUO; LIU; CHAO, 2004), (VIJAYABABU et al., 2005).

O flavopiridol (5) é uma flavona semi-sintética, análogo do alcaloide rohitukina, presente na planta indiana Dysoxylum binectariferum (WIRGER et al., 2005). Em 2006, já se encontrava em fase II de testes clínicos para muitos tumores. Até 2008, esta flavona (5) foi considerada o inibidor de CDK mais avançado (MORRIS et al., 2006). O flavopiridol (5) é um inibidor não seletivo que inibiu CDK4/ciclina D $\left(\mathrm{IC}_{50}=0,4 \mu \mathrm{M}\right)$, CDK2/ciclina A $\left(\mathrm{IC}_{50}=0,1 \mu \mathrm{M}\right)$, CAK (CDK Activating Kinase- Quinase ativadora de outra quinase) - (IC $50=0,3 \mu \mathrm{M})$ e CDK1/ciclina B (IC 50 $=0,4 \mu \mathrm{M}$ ) (LOSIEWICZ et al., 1994), (SEDLACEK et al., 1996). Contudo, o flavopiridol apresentou efeitos colaterais significativos e a partir disso, uma flavona de segunda geração (6) foi desenvolvida e exibiu alta atividade antiproliferativa em linhagens de células tumorais que 'superexpressam" ciclina D (JOSHI et al., 2007).

Os compostos 7 e 8, análogos do flavopiridol são inibidores seletivos da CDK2 (IC $50=0,11 \mu \mathrm{M}$ e 0,13 $\mu \mathrm{M}$, respectivamente). Esses análogos também inibiram a formação de colônias de células tumorais humanas, sendo também seletivos para a CDK2 e CDK4, respectivamente (KIM et al., 2000).

Compostos 9a e 9b (2-benzilideno-benzofuran-3-ona) é um inibidor potente e seletivo para CDK1 e CDK2 (SCHOEPFER et al., 2002). A fisetina (3, 7, 3', 4'tetrahidroxiflavona) (10) é um flavonol natural presente em vegetais, frutas e vinho, conhecido por seus efeitos anticancerígenos (LU et al., 2005a). Segundo Lu et al., (2005b), a fisetina (10) inibiu CDK6 ( $\left.\mathrm{IC}_{50}=0,85 \mu \mathrm{M}\right)$. Análogos 3-hidroxicromonas (11a, 11b, 12a e 12b) mostraram ser inibidores de CDK2. Os compostos 11a e 11b apresentaram valores de $\mathrm{IC}_{50}=4 \mu \mathrm{M}$ e $5 \mu \mathrm{M}$, respectivamente, enquanto 12a e 12b apresentaram $\mathrm{IC}_{50}=0,087 \mu \mathrm{M}$ e $0,075 \mu \mathrm{M}$, respectivamente (LEE et al., 2007). 
A indirubina (13), proveniente da medicina tradicional chinesa, foi reportada como inibidor de CDKs (IC50 CDK1/ciclina $B=10 \mu \mathrm{M}$, CDK5/p25 $=10 \mu \mathrm{M}$ ) (HOESSEL et al., 1999). O derivado indirubina-5-sulfonato (14) foi relatado como potente inibidor de CDK2 ( $\left.\mathrm{IC}_{50}=0,035 \mu \mathrm{M}\right)$ (KOSMOPOULOU et al., 2004). análogo 15 mostrou inibição de CDK1/ciclina $B\left(I_{50}=0,18 \mu \mathrm{M}\right)$, CDK5/p25 $\left(\mathrm{IC}_{50}=\right.$ $0,10 \mu \mathrm{M})$ (POLYCHRONOPOULOS et al., 2004). Segundo Ribas et al., (2006), o análogo 7-bromoindirubina-3'-oxima (16) apresentou fraca atividade inibitória de CDKs. Vários análogos de indirubina são inibidores de quinase promissores (17a17d) (BEAUCHARD et al., 2006).

Dentre os produtos naturais que exibiram forte atividade inibitória frente às CDKs, destaca-se a hymenialdisina ou HMD (18a), isolado de esponjas marinhas (CIMINO et al., 1982), (SHIMITZ et al., 1985). A hymenialdisina (18a) inibiu fortemente as quinases CDK1/ciclina $B\left(I_{50}=0,022 \mu \mathrm{M}\right)$, CDK2/ciclina $A\left(I_{50}=\right.$ 0,07 $\mu \mathrm{M})$, CDK2/ciclina E (IC $50=0,04 \mu \mathrm{M})$ e $\left(\mathrm{IC}_{50} \mathrm{CDK}_{5} / \mathrm{p} 25(0,028 \mu \mathrm{M})\right.$. Análogos (18b-18d) foram reportados com atividade de inibição frente às CDKs. A hymenialdisina (18a) e a fascaplysina (19) são os mais recentes produtos naturais identificados em esponjas marinhas com potencial inibição de quinases dependentes de ciclinas. A fascaplysina (19) inibiu CDK4/D1 $\left(\mathrm{IC}_{50}=0,35 \mu \mathrm{M}\right)$ e CDK6/D1 $\left(\mathrm{IC}_{50}=\right.$ 3,4 $\mu \mathrm{M}$ ) (PEYRESSATRE et al., 2015), (SONI et al., 2000) e (WAN et al., 2004).

A butirolactona (20) é um inibidor ATP-competitivo, isolada do fungo Aspergillus que inibiu seletivamente CDK1 $\left(\mathrm{IC}_{50}=0,68 \mu \mathrm{M}\right)$ e CDK2 $\left(\mathrm{IC}_{50}=0,82 \mu \mathrm{M}\right)$ (KITAGAWA et al., 1993). Apesar de sua fraca permeabilidade, a butirolactona apresentou efeitos antitumorais frente a linhagens de células de câncer de pulmão, pâncreas e cólon (NISHIO et al., 1996), (PEYRESSATRE et al., 2015), (WADA et al., 1998) e (YAMAMOTO et al., 1998). Os análogos hidrazona (21) e (22) foram reportados como inibidores de CDK1 e CDK2. Para esta última, o valor de $\mathrm{IC}_{50}$ é 0,0035 $\mu \mathrm{M}$, considerando o inibidor 21 e 0,0062 $\mu \mathrm{M}$ considerando o inibidor 22 (TOOGOOD, 2001).

Outro metabólito isolado também de fungo (Ceratocystis minor) é a acetoftalidina (23) que mostrou inibir a progressão do ciclo celular (CUI et al., 1996), (NOMOTO; MORI et al., 1997). Derivados diaril urea (24, 25 e 26) foram considerados seletivos inibidores de CDK4. O composto 24 apresentou $\mathrm{IC}_{50}=0,10$ $\mu \mathrm{M}$ para CDK4. O composto 25 inibiu CDK1 $\left(\mathrm{IC}_{50}=0,122 \mu \mathrm{M}\right), \mathrm{CDK} 2\left(\mathrm{IC}_{50}=0,08\right.$ $\mu \mathrm{M})$ e CDK4 $\left(\mathrm{IC}_{50}=0,042 \mu \mathrm{M}\right)$, enquanto que para o composto 26 os valores de $\mathrm{IC}_{50}$ 
foram respectivamente, $1,8 \mu \mathrm{M}, 0,44 \mu \mathrm{M}$ e 0,0023 $\mu \mathrm{M}$ para CDK1, CDK2 e CDK4, respectivamente (KAWANISHI et al., 2006).

Meriolinas (27) são compostos sintéticos obtidos a partir de 28 e 29, dois inibidores isolados de invertebrados marinhos. O composto 27c foi específico com relação a algumas CDKs com potencial sobre CDK2/ciclina $A\left(I_{50}=0,011 \mu \mathrm{M}\right)$, CDK9/ciclina $T\left(I_{50}=0,006 \mu \mathrm{M}\right)$. O composto 28b, em 2007, encontrava-se em testes pré-clínicos. Este composto inibiu de modo eficiente as CDKs 1, 2, 5 e 9 (IC 50 CDK1/ciclina $B=0,06 \mu \mathrm{M}$; CDK2/ciclina $A=0,08 \mu \mathrm{M} ;$ CDK5 $/$ p25 $=0,09 \mu \mathrm{M}$; CDK9/ciclina $\mathrm{T}=0,026 \mu \mathrm{M}$ ) (KAWANISHI et al., 2006).

Levando em consideração os dados de $\mathrm{IC}_{50}$ publicados para inibidores de CDKs, podemos fazer uma correlação com a estrutura-atividade desses inibidores uma vez que os mais promissores (Fig. 12, Tabela 1) apresentaram na sua estrutura a função $\mathrm{O}=\mathrm{C}-\mathrm{NH}$, que contém o oxigênio como aceptor de hidrogênio e o grupo $\mathrm{NH}$ como doador de hidrogênio. Entre as principais interações que devem ocorrer no sítio ativo de uma quinase, sem dúvidas, as interações de hidrogênio são as mais relevantes, principalmente para inibidores ATP-competitivos. 
Figura 12 - Inibidores naturais de CDKs e seus análogos (SHARMA; SHARMA; TYAGI, 2008).

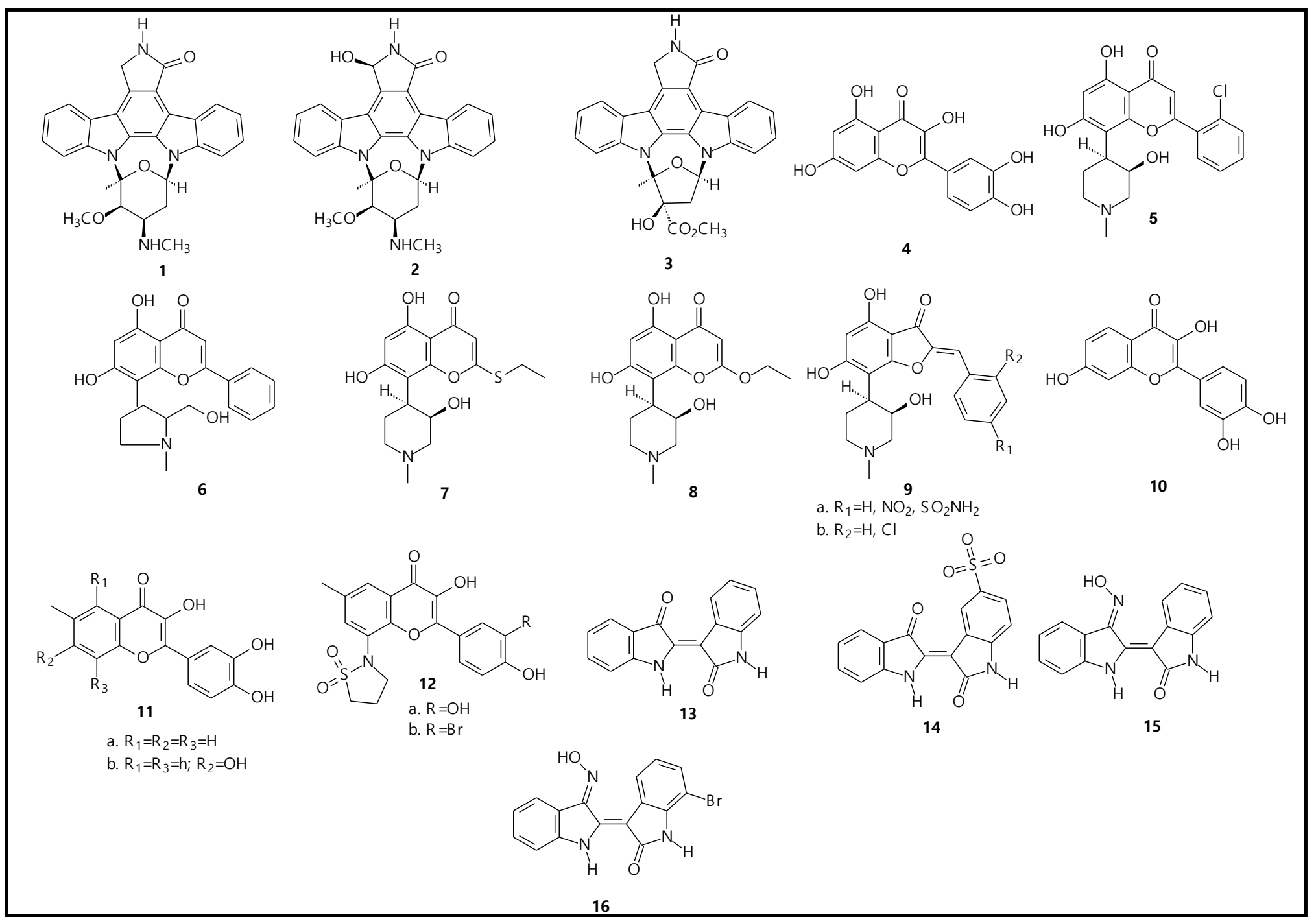




\section{Continuação da Figura 12}

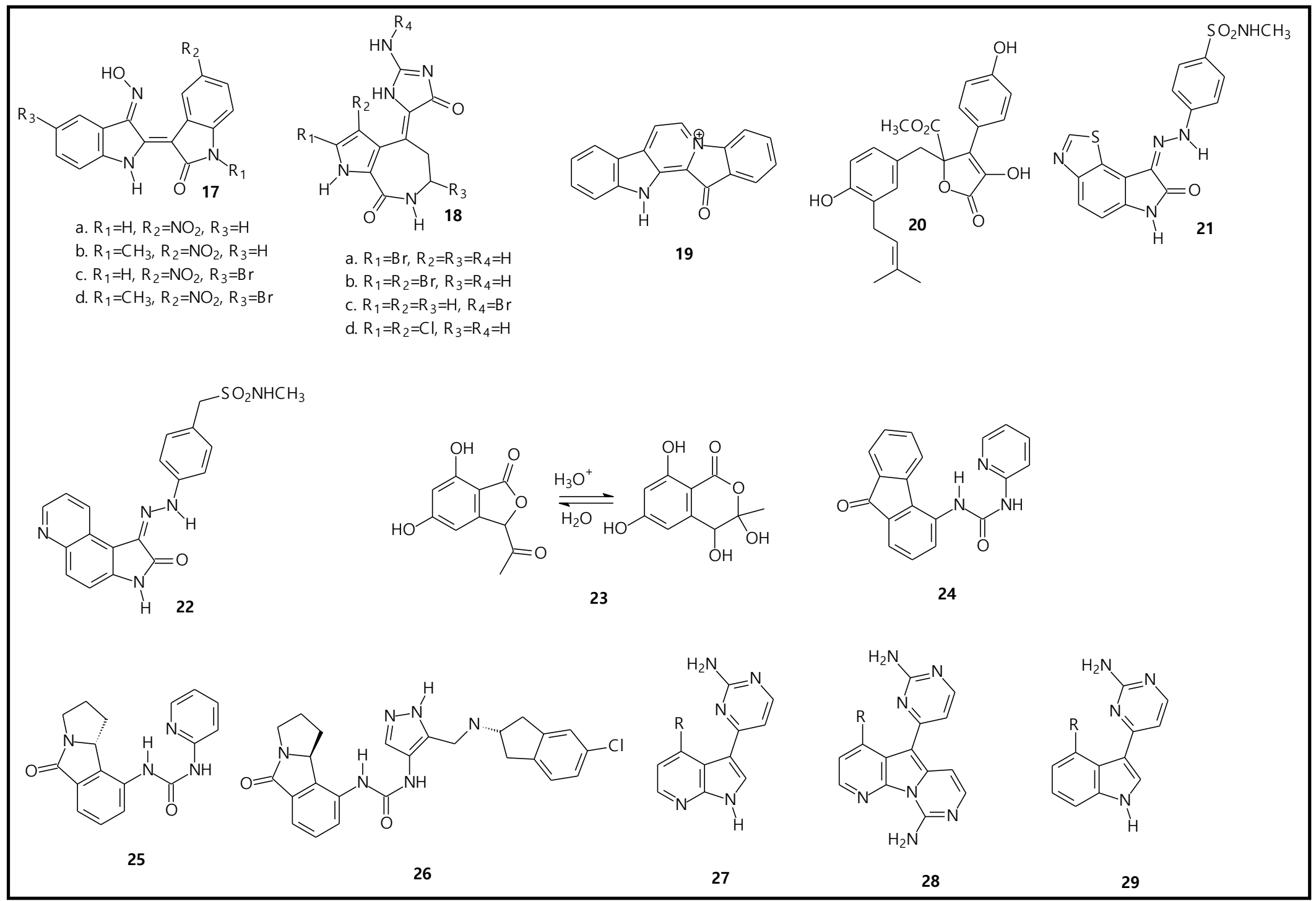




\subsection{Inibidores de CDK8/ciclina C}

Em meados de 2006, os principais substratos do complexo CDK8/ciclina C, ainda não tinham sido bem caracterizados, contudo, drogas inibidoras de CDKs, mostraram-se como potencial anti-inflamatório uma vez que promovem a apoptose de neutrófilos relacionados aos processos inflamatórios (ROSSI et al., 2006).

Estudos realizados por Cee et al., (2009), mostram que um membro da família das cortistatinas, cortistatina $A$ (30) liga com alta afinidade a um pequeno grupo de proteínas quinases, incluindo os membros da família das quinases dependentes de ciclinas, CDK8 e CDK11. As cortistatinas (30 - 32) (Fig. 10) compreendem uma família de 11 alcalóides esteroidais isolados de esponjas marinhas Corticium simplex, que podem atuar como inibidores, que no caso das CDKs 8 e 11 ligam-se ao sítio de ligação do ATP e bloqueiam sua função celular. Possuem, portanto, um interesse potencial na atividade antitumor (MEIJER; KIM, 1997).

Segundo Schneider et al., (2011), a CDK8 é o único membro da família de CDKs que interage com inibidores do tipo II. Como exemplo desta interação com o complexo CDK8/CycC pode ser citado o composto sorafenibe (Figura 14). Este composto interrompe a ponte de sal entre Glu66 ${ }^{\mathrm{CDK} 8}$ e Lys52 ${ }^{\mathrm{CDK} 8}$ e forma duas ligações de hidrogênio com Asp173 ${ }^{\mathrm{CDK} 8}$ e Glu66 ${ }^{\mathrm{CDK} 8}$ no motivo DMG. O sorafenibe faz ainda duas ligações de hidrogênio com a região do complexo CDK8/CycC (Ala100CDK8) e várias interações de van der Walls. Outras estruturas de inibidores tipo Il são mostrados na Figura 14 (RZYMSKI et al., 2015).

Em 2012, compostos da classe SNX (Senextinas), 4-aminoquiazolínicos, mostraram-se seletivos quanto à inibição da CDK8 e sua isoforma CDK19. Derivados carbonitrílicos (45), Senexina A (46) e Senexina B (47) (Figura 15), mostraram-se mais eficazes frente à inibição, sendo o composto Senexin $B$ o mais potente deles, uma vez que liga fortemente a CDK8 e CDK19 com valores de IC 50 para a CDK8 da ordem de 24 a $50 \mathrm{nM}$ (RZYMSKI et al., 2015). Os valores de IC 50 dos inibidores e os respectivos alvos estão sumarizados na Tabela 1.

Em adultos, a expressão da CDK8, em células diferenciadas, ocorre muito lentamente; entretanto, em células de CRC (câncer coloretal), a expressão é elevada, o mesmo pode ser observado em adenocarcinomas e células de câncer de mama, o que faz da CDK8 um importante alvo de inibidores da atualidade (FIRESTEIN et al., 2010). 
Figura 13 - Cortistatinas. Os números entre parênteses são os valores de $\mathrm{IC}_{50}$ para atividade antiproliferativa contra Células Endoteliais da Veia Umbilical Humana (HUVECs).

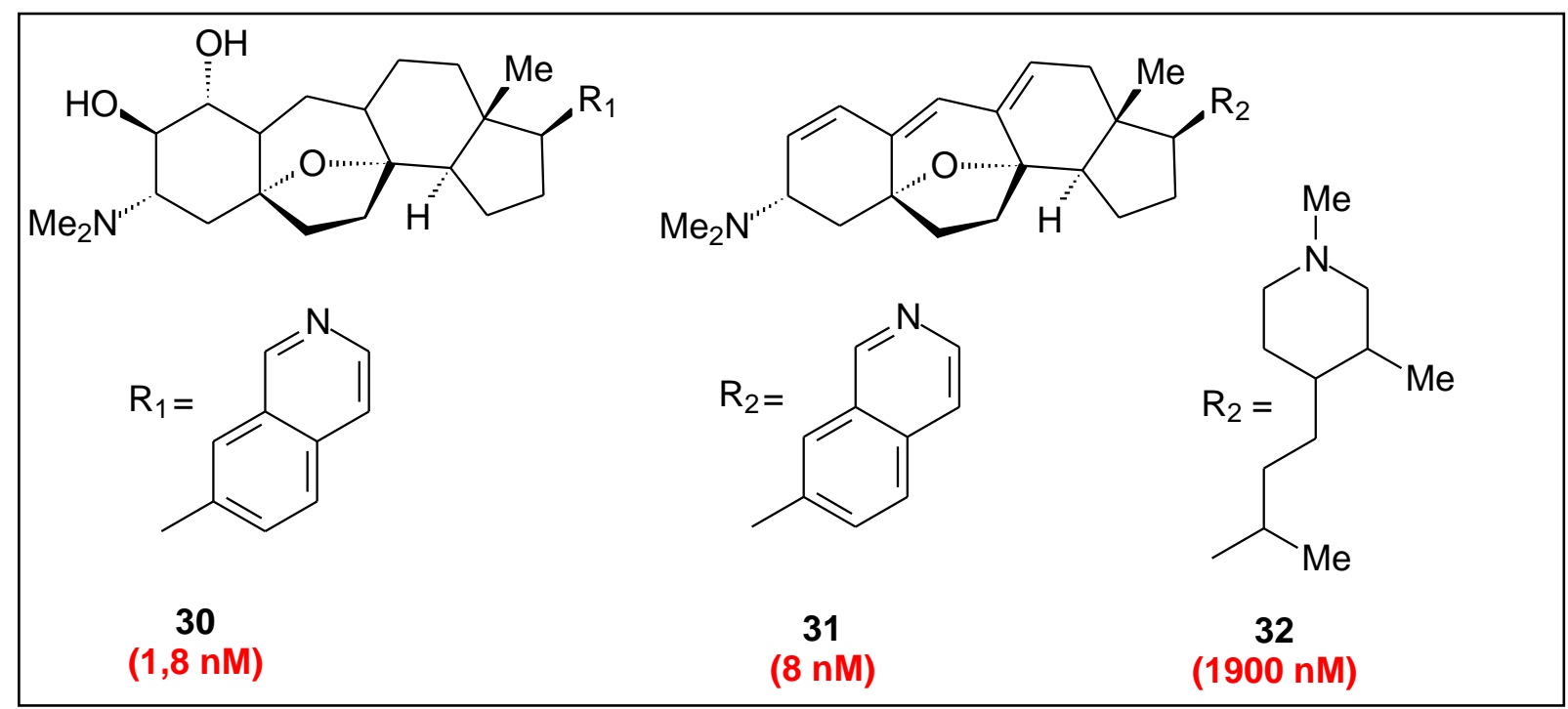

Fonte: Adaptado de Cee et al. (2009). 
Figura 14. Sorafenibe e outros inibidores de CDK8.

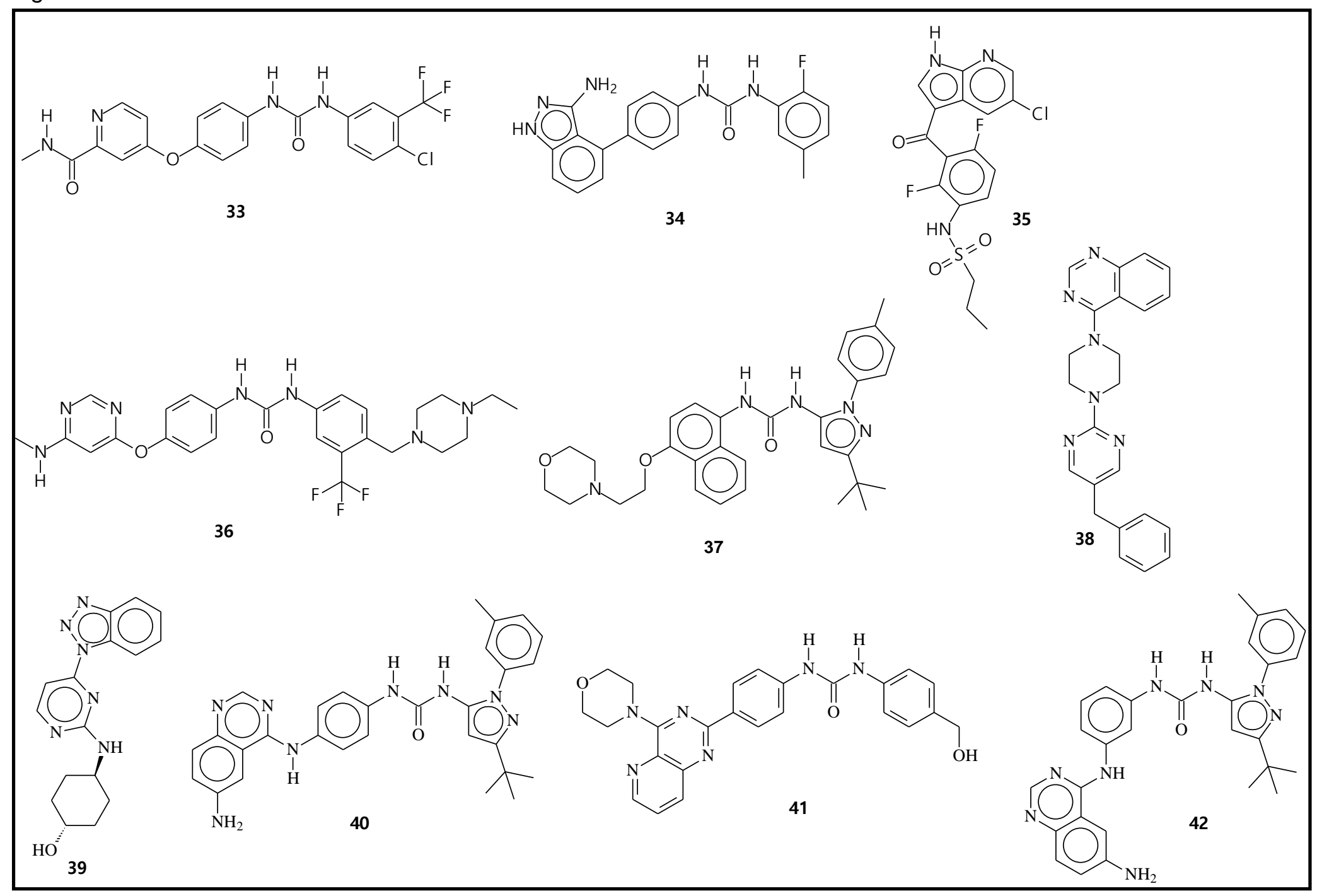

Fonte: Autoria própria. 
Figura 15 - Compostos da classe SNX (Senextinas) como inibidores de CDK8.

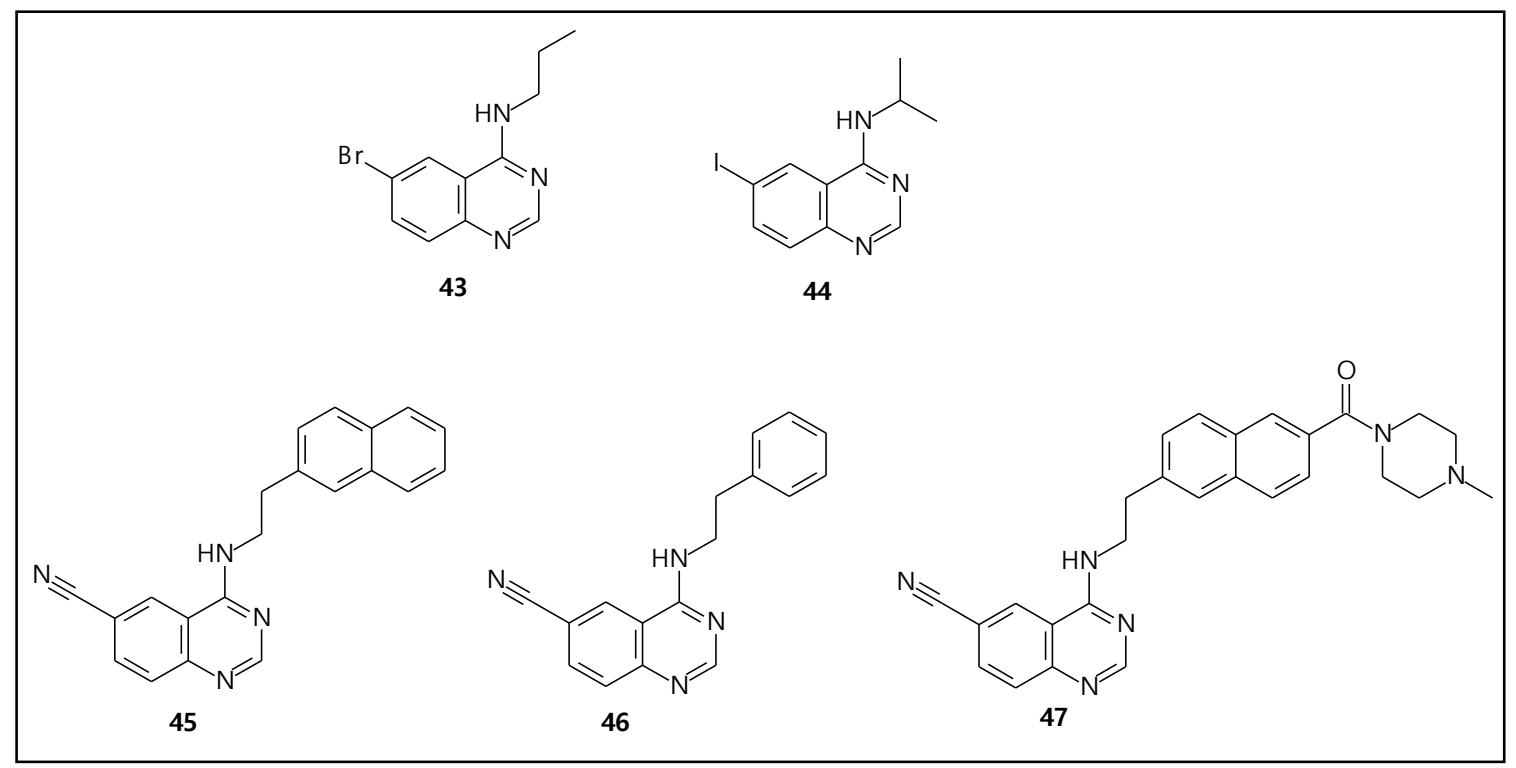

Fonte: Autoria própria. 
Tabela 1 - Inibidores de CDKs e seus respectivos alvos.

\begin{tabular}{|c|c|}
\hline Inibidores & Alvo \\
\hline \multirow[t]{2}{*}{ (1) } & CDK2/Ciclina A $\left(\mathrm{IC}_{50}=0,007 \mu \mathrm{M}\right)$ \\
\hline & CDK4/Ciclina D (IC 50 3-10 $\mu \mathrm{M})$ \\
\hline (2) & CDK2 $\left(\mathrm{IC}_{50}=0,03 \mu \mathrm{M}\right)$ \\
\hline \multirow[t]{3}{*}{ (5) } & CDK1/Ciclina B $\left(I C_{50}=0,4 \mu \mathrm{M}\right)$ \\
\hline & CDK2/Ciclina A $\left(\mathrm{IC}_{50}=0,1 \mu \mathrm{M}\right)$ \\
\hline & CDK4/Ciclina D $\left(\mathrm{IC}_{50}=0,4 \mu \mathrm{M}\right)$ \\
\hline (7) & $\operatorname{CDK} 2\left(\mathrm{IC}_{50}=0,11 \mu \mathrm{M}\right)$ \\
\hline (8) & CDK2 $\left(\mathrm{IC}_{50}=0,13 \mu \mathrm{M}\right)$ \\
\hline (10) & CDK6 $\left(\mathrm{IC}_{50}=0,85 \mu \mathrm{M}\right)$ \\
\hline (11a) & $\mathrm{CDK2}\left(\mathrm{IC}_{50}=4 \mu \mathrm{M}\right)$ \\
\hline (11b) & CDK2 $\left(\mathrm{IC}_{50}=5 \mu \mathrm{M}\right)$ \\
\hline (12a) & CDK2 $\left(\mathrm{IC}_{50}=0,087 \mu \mathrm{M}\right)$ \\
\hline (12b) & CDK2 $\left(I C_{50}=0,075 \mu \mathrm{M}\right)$ \\
\hline \multirow[t]{2}{*}{ (13) } & CDK1/Ciclina B $\left(I C_{50}=10 \mu \mathrm{M}\right)$ \\
\hline & $\mathrm{CDK5} / \mathrm{p} 25\left(\mathrm{IC} \mathrm{C}_{50}=10 \mu \mathrm{M}\right)$ \\
\hline (14) & $\mathrm{CDK} 2\left(\mathrm{IC}_{50}=0,035 \mu \mathrm{M}\right)$ \\
\hline \multirow[t]{2}{*}{ (15) } & CDK1/Ciclina B $\left(\mathrm{IC}_{50}=0,18 \mu \mathrm{M}\right)$ \\
\hline & CDK5/p25 $\left(\mathrm{IC}_{50}=0,010 \mu \mathrm{M}\right)$ \\
\hline \multirow[t]{4}{*}{ (18a) } & CDK1/Ciclina $B\left(\mathrm{IC}_{50}=0,022 \mu \mathrm{M}\right)$ \\
\hline & CDK2/Ciclina A $\left(\mathrm{IC}_{50}=0,07 \mu \mathrm{M}\right)$ \\
\hline & CDK2/Ciclina E $\left(\mathrm{IC}_{50}=0,04 \mu \mathrm{M}\right)$ \\
\hline & CDK5/p25 $\left(\mathrm{IC}_{50}=0,028 \mu \mathrm{M}\right)$ \\
\hline \multirow[t]{2}{*}{ (19) } & CDK4/Ciclina D1 $\left(\mathrm{IC}_{50}=0,35 \mu \mathrm{M}\right)$ \\
\hline & CDK6/Ciclina D1 $\left(\mathrm{IC}_{50}=3,4 \mu \mathrm{M}\right)$ \\
\hline \multirow[t]{2}{*}{ (20) } & CDK1 $\left(I C_{50}=0,68 \mu \mathrm{M}\right)$ \\
\hline & $\mathrm{CDK} 2\left(\mathrm{IC}_{50}=0,82 \mu \mathrm{M}\right)$ \\
\hline (21) & CDK2 $\left(\mathrm{IC}_{50}=0,0035 \mu \mathrm{M}\right)$ \\
\hline (22) & CDK2 (IC $50=0,0062 \mu \mathrm{M})$ \\
\hline (24) & $\operatorname{CDK} 4\left(I C_{50}=0,10 \mu \mathrm{M}\right)$ \\
\hline \multirow[t]{3}{*}{ (25) } & CDK1 $\left(\mathrm{IC}_{50}=0,122 \mu \mathrm{M}\right)$ \\
\hline & CDK2 $\left(I C_{50}=0,08 \mu \mathrm{M}\right)$ \\
\hline & CDK4 (IC $50=0,042 \mu \mathrm{M})$ \\
\hline \multirow[t]{3}{*}{ (26) } & $\operatorname{CDK1}\left(\mathrm{IC}_{50}=1,8 \mu \mathrm{M}\right)$ \\
\hline & $\mathrm{CDK} 2\left(\mathrm{IC}_{50}=0,44 \mu \mathrm{M}\right)$ \\
\hline & $\mathrm{CDK} 4\left(\mathrm{IC} \mathrm{C}_{50}=0,0023 \mu \mathrm{M}\right)$ \\
\hline \multirow[t]{2}{*}{ (27c) } & CDK2/Ciclina $\mathrm{A}\left(\mathrm{IC}_{50}=0,011 \mu \mathrm{M}\right)$ \\
\hline & CDK9 $/$ Ciclina $\mathrm{T}\left(\mathrm{IC}_{50}=0,006 \mu \mathrm{M}\right)$ \\
\hline \multirow[t]{4}{*}{ (28 b) } & CDK1/Ciclina B $\left(\mathrm{IC}_{50}=0,06 \mu \mathrm{M}\right)$ \\
\hline & CDK2/Ciclina A $\left(\mathrm{IC}_{50}=0,08 \mu \mathrm{M}\right)$ \\
\hline & $\mathrm{CDK} 5 / \mathrm{p} 25\left(\mathrm{IC} \mathrm{C}_{50}=0,09 \mu \mathrm{M}\right)$ \\
\hline & CDK9 $/$ Ciclina $\mathrm{T}\left(\mathrm{IC}_{50}=0,026 \mu \mathrm{M}\right)$ \\
\hline (30) & CDK8 $\left(I C_{50}=1,8 \mathrm{nM}\right)$ \\
\hline (31) & CDK8 $\left(I C_{50}=8 \mathrm{nM}\right)$ \\
\hline (32) & CDK8 $\left(I_{50}=1900 \mathrm{nM}\right)$ \\
\hline (47) & CDK8 (IC 50 24-50 nM) \\
\hline
\end{tabular}

Fonte: Autoria própria. 


\section{OBJETIVOS}

\subsection{Objetivo Geral}

Obter a proteína humana recombinante CDK8 em sistema de expressão heterólogo ( $E$. coli).

\subsection{Objetivos Específicos}

- $\quad$ Clonar o cDNA da CDK8;

- Expressar o recombinante pET28a::cdk8s em sistema heterólogo (Escherichia coli);

- $\quad$ Purificar a proteína recombinate humana CDK8;

- Realizar a análise de estrutura secundária por dicroísmo circular. 


\section{MATERIAIS E MÉTODOS}

\subsection{Data Mining e bioinformática}

A sequência de nucleotídeos correspondentes à proteína CDK8 foi obtida a partir da pesquisa no banco de dados GenBank (site: http://www.ncbi.nlm.nih.gov/genbank/) do portal NCBI (National Center for Biotechnology Information), com a identificação gi:4502744. Para verificar a sequência do DNA foi feita uma análise nucleotídica, utilizando a ferramenta de bioinformática BLAST (Basic Local Alignment Search Tool; site: http://blast.ncbi.nlm.nih.gov/Blast.cgi), a fim de compará-la com isoformas de CDK8. Com base nessa análise, o plasmídeo recombinante pET28a::cdk8 foi sintetizado pela empresa Epoch Life Science, o qual foi o material de partida deste projeto. Uma segunda abordagem, ainda com base nas análises de bioinformática, foi amplificar o cDNA da CDK8 a partir de bibliotecas de cDNA.

Posteriormente, duas construções foram realizadas: a primeira realizada com base em análises de estrutura secundária da proteína CDK8, em que foram retiradas da sequência do CDNA da CDK8, trechos correspondentes a regiões desordenadas do $\mathrm{N}$ e C-terminal da proteína. Esta análise foi realizada utilizando a ferramenta Psipred (http://bioinf.cs.ucl.ac.uk/psipred/), o que resultou num cDNA de 990 pb. Posteriormente, numa segunda construção, foram ainda retirados nucleotídeos correspondentes a uma extensão da região desordenada do C-terminal, assim como os códons raros da sequência codificante, os quais foram substituídos por códons existentes em E. coli. A análise dos códons raros foi realizada utilizando a ferramenta disponível no site https://www.genscript.com/tools/rare-codon-analysis. Utilizando esta última construção na amplificação e clonagem, foram realizados ensaios de expressão, solubilização e purificação da proteína CDK8, além de análise estrutural por espectropolarimetria de dicroísmo circular e fluorescência. 


\subsection{Amplificação do cDNA da CDK8 a partir do plasmídeo recombinante pET28a::cdk8}

Para a amplificação do cDNA da CDK8 a partir do plasmídeo recombinante pET28a::cdk8 (Fig. 16), foram construídos primers com os sítios de restrição para as enzimas Ndel na terminação 5' (Forward), e Hindlll na terminação 3' (Reverse). Estes primers foram sintetizados pela empresa Sigma Aldrich (Tabela 2).

Tabela 2 - Oligonucleotídeos (primers) utilizados na amplificação do cDNA a partir do plasmídeo recombinante pET28::cdk8a (Epoch Life Science). Os sítios de restrição estão destacados em negrito.

\begin{tabular}{ccc}
\hline Oligonucleotídeo & $\begin{array}{c}\text { Enzima de } \\
\text { restrição }\end{array}$ & Sequência dos oligonucleotídeos \\
\hline $\mathbf{F w}$ & Ndel & 5-AGTCATATGGAGGACCTGTTTGAATAC-3' \\
$\mathbf{R e v}$ & Hindlll & 5-AGTAAGCTTTCAGTCTGATGTAGGAAG-3' \\
\hline
\end{tabular}

Fonte: Autoria própria.

O primer Forward foi sintetizado com concentração de $48,6 \mathrm{mmol} / \mathrm{L}$ e sua temperatura de melting é $65^{\circ} \mathrm{C}$ e o Reverse foi sintetizado com concentração de 34,3 $\mathrm{mmol} / \mathrm{L}$ e temperatura de melting de $63^{\circ} \mathrm{C}$. Ambos foram diluídos para uma concentração de $100 \mu \mathrm{M}$ para a solução estoque, a partir da qual foi feita outra diluição para $10 \mu \mathrm{M}$ para a solução de uso, ambas estocadas à $-20^{\circ} \mathrm{C}$.

A amplificação do cDNA da CDK8 contido no plasmídeo recombinante foi feita pelo método da Reação em Cadeia da Polimerase (PCR, Polymerase Chain Reaction). Os reagentes e o programa do termociclador utilizados na PCR estão descritos nas Tabelas 3 e 4. 
Figura 16 - Mapa do plasmídeo sintético pET28a::cdk8.

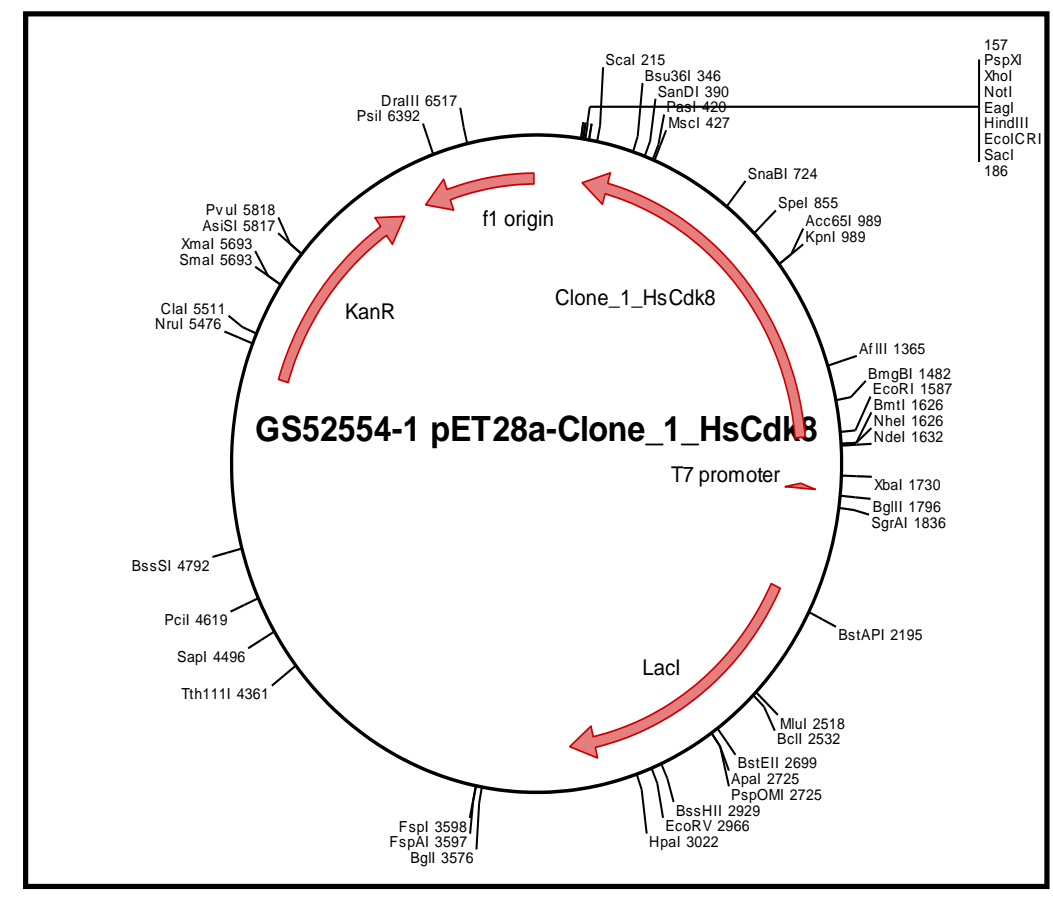

Fonte: Epoch Life Science.

Tabela 3 - Condições reacionais da PCR.

\begin{tabular}{cc}
\hline Reagentes & Volume $(\mu \mathrm{L})$ \\
\hline Tampão 10X HF $\left(+\mathrm{MgCl}_{2}\right)$ & 5 \\
dNTP mix $(10 \mathrm{mM})$ & 1 \\
Primer Forward $(1 \mu \mathrm{M})$ & 5 \\
Primer Reverse $(1 \mu \mathrm{M})$ & 5 \\
cDNA & 1 \\
HF enzyme mix $(2,5 \mathrm{U})$ & 0,5 \\
$\mathrm{H}_{2} \mathrm{O}$ & 32,5 \\
Total & 50
\end{tabular}

Fonte: Autoria própria. 
Tabela 4 - Programa do termociclador utilizado na amplificação do cDNA, utilizando um gradiente de temperatura entre 59,7 e $67^{\circ} \mathrm{C}$.

\begin{tabular}{|c|c|c|c|}
\hline $\begin{array}{c}\text { Temperatura } \\
\left({ }^{\circ} \mathrm{C}\right)\end{array}$ & $\begin{array}{c}\text { Tempo } \\
\text { (min/seg) }\end{array}$ & Etapa & \\
\hline 94 & 3 minutos & Desnaturação inicial & \\
\hline 94 & 30 segundos & Desnaturação & \\
\hline${ }^{*} \mathrm{Tm}-5$ & 30 segundos & Anelamento & $30 x$ \\
\hline 72 & 1 minutos/ kb & Extensão & \\
\hline 72 & 10 minutos & Extensão final & \\
\hline 4 & $\infty$ & - & \\
\hline
\end{tabular}

${ }^{*}$ Gradiente de temperatura de 59,$7 ; 60,9 ; 62,7 ; 65$ e $67^{\circ} \mathrm{C}$.

Fonte: Autoria própria.

Definida a temperatura de amplificação, foi realizada nova reação de PCR a $60,9^{\circ} \mathrm{C}$, seguindo o mesmo programa do termociclador para produtos de PCR $\leq 3$ Kb. Após a amplificação, foi realizado eletroforese em gel de agarose a 0,8\% utilizando o produto de PCR. A banda referente ao cDNA da CDK8, de 990 pb, foi purificada utilizando-se o QIAquick Gel Extraction Kit (QIAGEN).

Para determinar a concentração do cDNA purificado, utilizou-se o equipamento DS-11+Spectrophotometer (DeNovix), pertencente ao Laboratório de Química Medicinal (Nequimed), sob coordenação do Prof. Dr. Carlos Alberto Montanari.

\subsection{Clonagem do cDNA que codifica a CDK8}

\subsubsection{Ligação do CDNA ao vetor de propagação pCR-Blunt}

O cDNA foi submetido à reação de ligação ao vetor pCR-Blunt (Zero Blunt PCR Cloning - Invitrogen) (Fig. 17), utilizando a T4 DNA Ligase (Thermo Scientific) (Tabela 5). Este vetor é responsável pelo transporte do fragmento de interesse para as células hospedeiras, além de possuir um marcador selecionável, isto é, um gene que permita a seleção das células que contém o plasmídeo, possui uma origem de replicação para sua propagação e sítios de clonagem para a inserção do fragmento de interesse. 
Figura 17 - Mapa do vetor pCR-Blunt (Invitrogen).

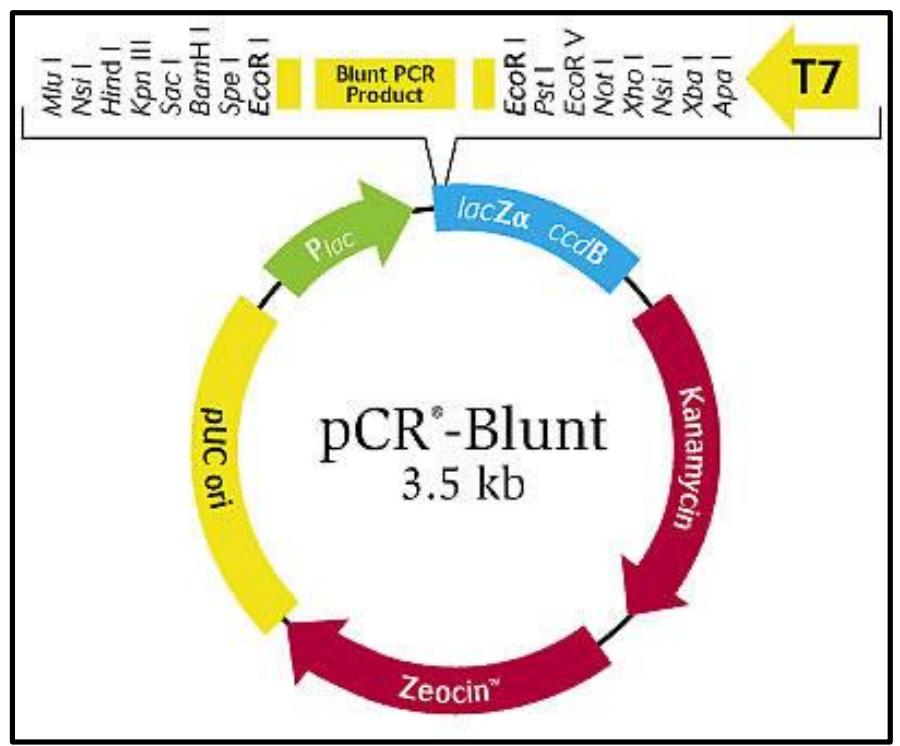

Fonte: https://www.thermofisher.com/order/catalog/product/K270020.

A quantidade de DNA utilizado na reação de ligação com o vetor pCR-Blunt foi determinada pela equação abaixo:

$$
\mathrm{X}(\mathrm{ng}) \mathrm{de} \text { inserto }=\frac{10 \times Y p b \text { produto PCR } \times 25 n g p C R-\text { Blunt }}{3500 p b p C R-\text { Blunt }}
$$

Onde:

$\mathrm{X}=$ quantidade em nanogramas (ng) de DNA (inserto)

$\mathrm{Y}=$ número de pares de bases $(\mathrm{pb})$ do inserto

Tabela 5 - Reação de ligação do vetor pCR-Blunt ao cDNA da CDK8 utilizando a T4 DNA Ligase (Thermo Scientific).

\begin{tabular}{cc}
\hline Reagentes & Volume $(\mu \mathrm{L})$ \\
\hline pCR-Blunt (25 ng) & 1,0 \\
DNA CDK8 (inserto) & 6,0 \\
Tampão $10 \mathrm{X}$ & 1,0 \\
T4 DNA ligase (4U/ $\mu \mathrm{L} ;$ Fermentas). & 1,0 \\
Água estéril & 1,0 \\
Total & 10,0
\end{tabular}

Fonte: Autoria própria. 
A reação de ligação no vetor pCR-Blunt foi realizada a $16^{\circ} \mathrm{C}$ durante 3 horas. Em seguida, fez-se a transformação do produto de ligação em diferentes estoques de células DH5a quimicamente competentes, utilizando o protocolo de Sambrook e Russel (2001).

\subsubsection{Ligação do cDNA da CDK8 ao vetor de expressão pET28a}

Procedeu-se com a ligação do cDNA da CDK8 ao vetor de expressão pET28a.

A ligação foi feita segundo a equação abaixo:

$$
X(n g)=\frac{(100 n g \text { do vetor linear }) x(p b \text { inserto })}{(p b \text { vetor })}
$$

Onde:

$X=$ quantidade em nanogramas $(\mathrm{ng})$ de inserto

$p b$ inserto $=$ número de pares de bases do inserto

pb vetor $=$ número de pares de bases do vetor

A ligação foi realizada na proporção inserto/vetor (3:1), (2:1) e (5:1). Após 16 $\mathrm{h}$ de reação, os produtos de ligação foram transformados em células DH5a (quimicamente competentes e eletrocompetentes) e XL1-blue (quimicamente competentes) (SAMBROOCK; RUSSEL, 2001), seguido por inóculo de diferentes colônias e posterior purificação utilizando miniprep (DNA plasmidial GeneJet ${ }^{T M}$ Plasmid Miniprep Kit - Fermentas).

\subsubsection{Preparação de um novo primer $p E T_{\text {Forward }}$}

Devido às dificuldades encontradas nas etapas de ligação do inserto ao vetor de clonagem e também ao vetor de expressão pET28a, optou-se por desenhar um primer, designado $p E T_{\text {Forward }}$ (5'-ATTAAGCTTCCACAGTACTCACAATCAG-3'), que anelaria a um segmento do próprio vetor pET28a do recombinante pET28a::cdk8 (Epoch Life Science), aproveitando o primer Rev anterior (5'AGTAAGCTTTCAGTCTGATGTAGGAAG-3’). 
Os primers foram diluídos a uma concentração de $10 \mu \mathrm{M}$, e a PCR foi realizada utilizando-se a enzima Taq DNA polimerase High Fidelity Mix da Thermo Scientific, e, em outro experimento, a DNA polimerase Phusion Hot Start II, de acordo com os volumes de reagentes e protocolos de reação descritos nas Tabelas 6-9.

Tabela 6 - Reação de PCR utilizando o novo primer pET $\mathrm{Fw}_{\mathrm{w}}$ e a enzima Taq $\mathrm{HiFi}$.

\begin{tabular}{cc}
\hline Reagentes & Volume $(\mu \mathrm{L})$ \\
\hline Água esterilizada & 32,0 \\
Tampão 10 X High Fidelity PCR & 5,0 \\
dNTP mix (2 mM) & 2,0 \\
Primer pET Fw & 5,0 \\
Primer Rv & 5,0 \\
DNA molde & 0,5 \\
Enzima High Fidelity Mix & 0,5 \\
Total & 50
\end{tabular}

Fonte: Autoria própria.

Tabela 7 - Condições utilizadas na reação de amplificação para fragmentos maiores que $3 \mathrm{~kb}$.

\begin{tabular}{cccc}
\hline $\begin{array}{c}\text { Temperatura } \\
{ }^{\circ} \mathrm{C}\end{array}$ & $\begin{array}{c}\text { Tempo } \\
(\mathrm{min} / \mathrm{seg})\end{array}$ & $\begin{array}{c}\text { Etapa } \\
\text { ciclos }\end{array}$ \\
\hline 94 & $02: 30$ & Desnaturação inicial & 1 \\
95 & $00: 45$ & Desnaturação & - \\
$*$ Tm -5 & $00: 40$ & Anelamento & 10 \\
68 & $07: 00$ & Extensão & - \\
95 & $00: 45$ & Desnaturação & - \\
$*$ Tm -5 & $00: 40$ & Anelamento & 20 \\
68 & $10: 00$ & Extensão & - \\
68 & $10: 00$ & Elongação final & 1 \\
4 & $\infty$ & - & - \\
\hline
\end{tabular}

*gradiente: 49,$4 ; 53,8 ; 56,7 ; 59,0$ e $61,4^{\circ} \mathrm{C}$.

Fonte: Autoria própria. 
Tabela 8 - Reação de PCR utilizando o novo primer pET $\mathrm{Fw}_{\mathrm{F}}$ e a enzima Phusion Hot Start II (Thermo Scientific).

\begin{tabular}{cc}
\hline Reagentes & Volume $(\mu \mathrm{L})$ \\
\hline Água esterilizada & 26,5 \\
Tampão 5 X HF & 10,0 \\
dNTP mix (10 mM) & 1,0 \\
Primer Fw & 5,0 \\
Primer Rv & 5,0 \\
DNA molde & 0,5 \\
DMSO & 1,5 \\
Enzima High Fidelity Mix & 0,5 \\
Total & 50,0
\end{tabular}

Fonte: Autoria própria.

Tabela 9 - Condições utilizadas na reação de amplificação para fragmentos maiores que $3 \mathrm{~kb}$.

\begin{tabular}{cccc}
\hline $\begin{array}{c}\text { Temperatura } \\
{ }^{\circ} \mathrm{C}\end{array}$ & $\begin{array}{c}\text { Tempo } \\
(\mathrm{min} / \mathrm{seg})\end{array}$ & $\begin{array}{c}\text { Etapa } \\
\text { címero de } \\
\text { ciclos }\end{array}$ \\
\hline 98 & $00: 30$ & Desnaturação inicial & 1 \\
98 & $00: 10$ & Desnaturação & - \\
${ }^{*} \mathrm{Tm}-5$ & $00: 30$ & Anelamento & 35 \\
72 & $02: 30$ & Extensão & - \\
72 & $10: 00$ & Extensão final & - \\
4 & $\infty$ & - & - \\
\hline
\end{tabular}

*gradiente: $68 ; 66 ; 64,1 ; 61,7$ e $58,7^{\circ} \mathrm{C}$.

Fonte: Autoria própria.

Após a reação de PCR, aplicou-se o produto de PCR em gel de agarose 0,8\% para a realização da purificação da banda referente ao cDNA da CDK8, utilizando o kit de extração em gel (GeneJET Gel Extraction Kit, Thermo Fisher).

\subsection{Amplificação e clonagem do cDNA da CDK8 a partir de biblioteca de cDNA de cérebro fetal e leucócitos}

Frente às dificuldades enfrentadas, uma nova possibilidade foi realizar a amplificação do cDNA da CDK8 a partir de biblioteca de CDNA de cérebro fetal 
humano - CLONTECH (200 ng/ $\mu \mathrm{L})$, gentilmente cedida pela Profa. Dra. Ana Paula Ulian de Araújo do grupo de Biofísica Molecular "Sérgio Mascarenhas" do Instituto de Física de São Carlos, e adicionalmente, a partir de biblioteca de cDNA de leucócitos - CLONTECH (200 ng/ $\mu \mathrm{L})$, gentilmente cedida pela Profa. Paula Rahal da UNESP de São José do Rio Preto/SP.

A reação de PCR foi realizada utilizando-se os primers abaixo, os quais possuem os sítios de restrição para Ndel e Hindlll para as sequências forward e reverse, respectivamente (Tabela 10$)$.

Primer Fw - 5’ AGTCATATGGAGGACCTGTTTGAATAC 3’ (TM = 65,0)

Primer Rv - 5’ AGTAAGCTTTCAGTCTGATGTAGGAAG 3' (TM = 63,0)

Tabela 10 - Reação de PCR utilizada na amplificação do cDNA da CDK8, a partir de bibliotecas de cDNA de cérebro fetal e de leucócitos.

\begin{tabular}{cc}
\hline Reagentes & Volume $(\mu \mathrm{L})$ \\
\hline Água esterilizada & 28,0 \\
Tampão HF 5X & 10,0 \\
dNTP 10 mM & 1,0 \\
Primer Fw & 5,0 \\
Primer Rv & 5,0 \\
DNA molde* & 0,5 \\
Enzima High Fidelity Mix & 0,5 \\
Total & 50,0 \\
\hline
\end{tabular}

${ }^{*}$ Experimentos realizados separadamente para cada molde.

Fonte: Autoria própria. 
Tabela 11 - Condições reacionais utilizadas na amplificação de fragmentos maiores que $3 \mathrm{~kb}$.

\begin{tabular}{cccc}
\hline $\begin{array}{c}\text { Temperatura } \\
{ }^{\circ} \mathrm{C}\end{array}$ & $\begin{array}{c}\text { Tempo } \\
(\mathrm{min} / \mathrm{seg})\end{array}$ & $\begin{array}{c}\text { Etapa } \\
\text { Número de } \\
\text { ciclos }\end{array}$ \\
\hline 98 & $00: 30$ & Desnaturação inicial & 1 \\
98 & $00: 10$ & Desnaturação & - \\
$* \mathrm{Tm}-5$ & $00: 30$ & Anelamento & 35 \\
72 & $02: 30$ & Extensão & - \\
72 & $10: 00$ & Extensão final & - \\
4 & $\infty$ & - & - \\
\hline
\end{tabular}

*gradiente: 59,$4 ; 60,9 ; 64,2 ; 65,8$ e 67,4 .

Fonte: Autoria própria.

Uma vez confirmada a amplificação a partir da biblioteca de cDNA de cérebro fetal através do gel de agarose $0,8 \%$, foram realizadas duas outras reações de PCR, em condições idênticas às anteriores, nas temperaturas de $65,8^{\circ} \mathrm{C}$ e $60^{\circ} 9^{\circ} \mathrm{C}$. As bandas referentes ao produto da amplificação foram purificadas utilizando-se o kit GeneJET Gel Extraction da Thermo Scientific.

Com o objetivo de obter maior concentração de cDNA para a etapa de clonagem, optou-se por realizar cinco reações de PCR nas mesmas condições anteriores, porém apenas a $60,9^{\circ} \mathrm{C}$. Após a reação, observou-se bandas em aproximadamente $990 \mathrm{pb}$, a partir do gel de agarose $0,8 \%$, as quais foram purificadas e quantificadas conforme descrito anteriormente.

O cDNA de 990 pb foi digerido com as enzimas Ndel e Hindll Fast Digest (Fermentas), utilizando-se as condições descritas na Tabela 12.

Tabela 12 - Reação de clivagem do produto de PCR para obtenção de extremidades complementares ao vetor de expressão pET28a.

\begin{tabular}{cc}
\hline Reagentes & Volume $(\mu \mathrm{L})$ \\
\hline Água esterilizada & 0 \\
Tampão 10X & 13,0 \\
cDNA da CDK8 $(2,3 \mu \mathrm{g})$ & 112,0 \\
Ndel & 2,5 \\
Hindll & 2,5 \\
Total & 130 \\
\hline
\end{tabular}

Fonte: Autoria própria. 
A reação de digestão foi realizada à temperatura de $37^{\circ} \mathrm{C}$ por 4 horas. Ao final da reação inativaram-se as enzimas mantendo-as a $80 \stackrel{\circ}{\circ}$ por 20 minutos. Em seguida, a amostra foi purificada com o kit de extração em gel Wizard® SV Gel and

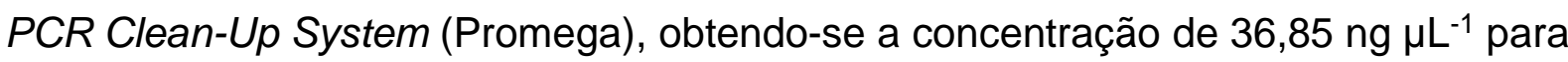
o cDNA da CDK8. A ligação ao vetor de expressão pET28a, também previamente digerido com as mesmas enzimas foi realizada na proporção inserto:vetor (3:1).

Assim, partindo-se do vetor pET28a linear com concentração de 30,66 ng $\mu \mathrm{L}^{-1}$

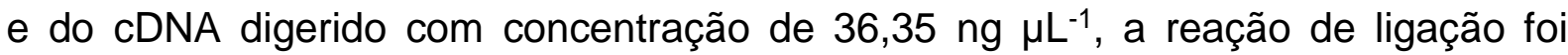
realizada utilizando-se a enzima $T 4$ DNA ligase (Fermentas) nas condições descritas na Tabela 13.

Tabela 13 - Reação de ligação do cDNA da CDK8 ao vetor pET28a.

\begin{tabular}{cc}
\hline Reagentes & Volume $(\mu \mathrm{L})$ \\
\hline Água autoclavada & 3,1 \\
Tampão T4 DNA ligase 10X & 1 \\
cDNA da CDK8 & 1,6 \\
Vetor pET28a linear & 3,3 \\
T4 DNA ligase & 1
\end{tabular}

Fonte: Autoria própria.

A reação foi realizada a $16 \stackrel{\circ}{\circ}$ por 4 horas. Em seguida, realizou-se a transformação do produto de ligação em células DH5a. Quatro colônias transformadas foram selecionadas e repicadas da placa de Petri para a realização de pré-inóculos. Após 12 horas estes apresentaram o meio turvo e, assim, realizouse a purificação do DNA recombinante pET28a::cdk8 utilizando miniprep (Thermo Scientific).

Para confirmação da ligação pET28a::cdk8 foi realizado o teste de restrição com as enzimas Ndel e Hindll, seguido do sequenciamento em equipamento 3130 Genetic Analyzer (Applied Biosystems) do Laboratório de Biologia Molecular do Grupo de Cristalografia do Instituto de Física de São Carlos - IFSC/USP. 


\subsection{Obtenção da sequência codificante da CDK8 sem códons raros}

Dificuldades na obtenção de resultados conduziram à nova pesquisa no GenBank (http://www.ncbi.nlm.nih.gov/genbank/) do portal NCBI (National Center for Biotechnology Information), com o objetivo de confirmar ou redefinir uma nova sequência de cDNA da CDK8, e submetê-la a análises para verificação da presença de códons raros em E. coli. Mantendo a sequência obtida anteriormente (gi:4502744), esta foi submetida a análise no software Rare Codon Calculator (RaCC - http://nihserver.mbi.ucla.edu/RACC/), para a identificação dos códons raros presentes na sequência, os quais puderam ser substituídos por códons presentes em E. coli. Adicionalmente, análises da predição de estrutura secundária da CDK8, realizada pela ferramenta psipred (http://bioinf.cs.ucl.ac.uk/psipred/), somada a análise da estrutura de CDKs depositadas no PDB (https://www.rcsb.org/) conduziram a remoção do C-terminal da cadeia polipeptídica (Gln331-Tyr464). Para tanto, a nova sequência de DNA foi sintetizada pela Invitrogen (CDK8 $\Delta$ ), tendo esta construção 990 pb, o que codifica uma proteína de 330 resíduos de aminoácidos e $43 \mathrm{kDa}$. Os sítios de restrição para as enzimas Ndel e EcoRl foram introduzidos nas extremidades 5' e 3' da sequência de DNA, respectivamente, os quais permitiriam a obtenção de extremidades complementares, após digestão das respectivas enzimas e obtenção do recombinante pET28a::cdk8 $\Delta$.

\subsubsection{Obtenção do recombinante pET28a::cdk8 $\triangle$}

As enzimas de restrição Ndel e EcoRI (Thermo Scientific) foram utilizadas para clivar o DNA da CDK8 $\Delta$ e o vetor de expressão pET28a. As soluções contendo o vetor pET28a e o DNA utilizadas na reação de digestão continham 72,72 e 20 ng/ $\mu \mathrm{L}$, respectivamente. O protocolo com os reagentes utilizados está descrito na Tabela 14. 
Tabela 14 - Reação de digestão do DNA da CDK8 $\Delta$ e do vetor de expressão pET28a.

\begin{tabular}{ccc}
\hline Reagentes & \multicolumn{2}{c}{ Volume $(\mu \mathrm{L})$} \\
\hline Água esterilizada & cDNA & pET28a $(+)$ \\
Tampão O 10X & 6 & 4 \\
cDNA & 2 & 2 \\
Ndel & $5(100 \mathrm{ng})$ & $7(509,05 \mathrm{ng})$ \\
EcoRI & 1,5 & 1,5 \\
Total & 1,5 & 1,5 \\
& 16 & 16 \\
\hline
\end{tabular}

Fonte: Autoria própria.

Os produtos da digestão foram purificados com o auxílio do kit GeneJET Gel Extraction (Thermo Scientific), e quantificados com o auxílio do aparelho DS$11+$ Spectrophotometer (DeNovix).

Em seguida, realizou-se a reação de ligação do DNA alvo com o vetor de expressão pET28a linearizado. Para os protocolos de clonagem padrão a concentração recomendada de vetor é de 1 a $10 \mathrm{ng} \mu \mathrm{L}^{-1}$. Portanto, para uma reação de $20 \mu \mathrm{L}$ pode ser utilizado até $200 \mathrm{ng}$ de vetor de expressão. A razão inserto:vetor recomendada é, em geral, de 2 a 3 vezes em relação ao vetor. Desta forma, utilizouse a razão 3 (inserto):1 (vetor de expressão). A ligação foi realizada pela enzima T4 DNA ligase $(1 \mu \mathrm{L}), 34 \mathrm{ng}(4,6 \mu \mathrm{L})$ do vetor pET28a e $100 \mathrm{ng}(15 \mu \mathrm{L})$ do DNA previamente digeridos e purificados. A duração da reação foi de 14 horas à temperatura de $22{ }^{\circ} \mathrm{C}$. Após o término, a enzima foi inativada a $65 \stackrel{\circ}{\mathrm{C}}$ por 15 minutos. Os reagentes utilizados na reação de ligação estão descritos na Tabela 15. 
Tabela 15 - Reagentes utilizados na reação de ligação pET28a::cdk8

\begin{tabular}{cc}
\hline Reagentes & Volume $(\mu \mathrm{L})$ \\
\hline Água esterilizada & --- \\
Tampão T4 DNA ligase 10X & 2 \\
Fragmento de cDNA & 15 \\
Vetor linear & 4,6 \\
T4 DNA ligase [5U/L Fermentas] & 1 \\
Total & 22,6 \\
\hline
\end{tabular}

Fonte: Autoria própria.

Posteriormente, realizou-se a transformação, através do choque térmico, em células de E. coli da linhagem DH5a competentes (Novagen), com o objetivo de multiplicar os vetores plasmidiais. Foram adicionados à reação $100 \mu \mathrm{L}$ de células competentes $\mathrm{DH} 5$ a e $10 \mu \mathrm{L}$ do produto obtido na reação de ligação, o recombinante pET28a::cdk8 4 . Após 20 minutos de incubação no gelo, foi dado um choque térmico a $42{ }^{\circ} \mathrm{C}$ por 1:30 minutos e, em seguida, as células foram encubadas em gelo por mais 3 minutos. Foram adicionados $400 \mu \mathrm{L}$ de meio LB líquido (Luria-Bertani pH 7,0 - $1 \mathrm{~g}$ de triptona (Neogen), 0,5 g de extrato de levedura (Neogen), $1 \mathrm{~g}$ de $\mathrm{NaCl}$ (Synth), $90 \mathrm{~mL}$ de água destilada) previamente aquecido a $37^{\circ} \mathrm{C}$. Esta reação de transformação, foi mantida sob agitação a $150 \mathrm{rpm}$ e $37^{\circ} \mathrm{C}$ por 1 hora. Após centrifugação por 1 minuto a $22{ }^{\circ} \mathrm{C}$ e $14000 \mathrm{rpm}$, seguida de ressuspensão, $100 \mu \mathrm{L}$ desta ressuspensão foram aplicadas em placa de Petri contendo meio LB sólido (análogo ao meio LB líquido exceto pela adição de ágar - Neogen) e o antibiótico para a seleção das colônias que possuem o plasmídeo recombinante. No caso do pET28a, foram utilizados $50 \mu \mathrm{g} \mathrm{mL}^{-1}$ do antibiótico canamicina (Sigma Aldrich). As placas foram encubadas a $37^{\circ} \mathrm{C}$ por 16 horas.

Após a transformação em células $\mathrm{DH} 5 \alpha$, foram preparados pré-inóculos das colônias observadas. Estas foram repicadas e transferidas para um tubo de ensaio contendo $5 \mathrm{~mL}$ de meio LB líquido e $50 \mu \mathrm{g} \mathrm{mL}^{-1}$ do antibiótico canamicina. Os tubos de ensaio foram encubados a $37^{\circ} \mathrm{C}$, sob agitação $(250 \mathrm{rpm} / 12$ horas $)$. 
A partir do pré-inóculo realizou-se a purificação dos plamídeos recombinantes, utilizando o kit de extração de DNA plasmidial GeneJET Plasmid Miniprep Kit (Thermo Scientific).

Para testar a efetividade da ligação realizou-se o teste de restrição de 2 amostras referentes às colônias $A$ e B. Esse teste consiste na digestão do plasmídeo recombinante pET28a::cdk8 com as enzimas de restrição Ndel e EcoRI. Desta forma, foram realizados dois testes de restrição, referentes aos minipreps $\mathrm{A} e$ $\mathrm{B}$, cujos reagentes utilizados estão representados na Tabela 16. Essas amostras foram aplicadas em gel de agarose $0,8 \%$ a fim de analisar as bandas relativas ao fragmento de cDNA liberado (1077 pb) e ao vetor pET28a.

Tabela 16 - Reagentes utilizados no teste de restrição.

\begin{tabular}{ccc}
\hline Reagentes & \multicolumn{3}{c}{ Volume $(\mu \mathrm{L})$} \\
\hline & Miniprep A & Miniprep B \\
Água esterilizada & 10 & 10 \\
Tampão O 10X & 2 & 2 \\
DNA plasmidial & 5 & 5 \\
Ndel & 1,5 & 1,5 \\
EcoRI & 1,5 & 1,5 \\
Total & 20 & 20 \\
\hline
\end{tabular}

Fonte: Autoria própria.

\subsubsection{Expressão da CDK84-HisTag em E. coli}

A proteína CDK8 proveniente da expressão do plasmídeo recombinante pET28a::cdk8 $\Delta$ foi expressa com uma cauda de poli-histidina (HisTag) no N-terminal. Para fins didáticos, a proteína CDK8 será designada como CDK8-Histag.

Células de E. coli da linhagem Rosetta(DE3) (Novagen) foram transformadas com o plasmídeo recombinante pET28a::cck84. Após a seleção de colônias, estas foram transferidas para $20 \mathrm{~mL}$ de meio líquido LB contendo os mesmos antibióticos (canamicina e cloranfenicol $50 \mathrm{mg} / \mathrm{mL}$ ), e a cultura foi conduzida a $20^{\circ} \mathrm{C}$, a $200 \mathrm{rpm}$ 
por 14 horas. Em seguida, os $20 \mathrm{~mL}$ foram transferidos para $1 \mathrm{~L}$ de meio líquido otimizado (20 g/L de triptona, $10 \mathrm{~g} / \mathrm{L}$ de extrato de levedura, $5 \mathrm{~g} / \mathrm{L}$ de $\mathrm{NaCl}, 4 \mathrm{~g} / \mathrm{L}$ de $\mathrm{KCl}, 3 \mathrm{~g} / \mathrm{L}$ de $\mathrm{MgCl}_{2}$ e $1 \%$ de glicerol) até a densidade óptica a $600 \mathrm{~nm}$ atingir a absorbância entre 0,4 e 0,6. Neste ponto, a expressão foi induzida pela adição de IPTG 0,2 mM, e mantida a temperatura constante $\left(20^{\circ} \mathrm{C}\right)$, a $150 \mathrm{rpm}$, por cerca de 16 horas (overnight).

As células foram centrifugadas e ressuspendidas em $15 \mathrm{~mL}$ do tampão de lise ou tampão A [Hepes $50 \mathrm{mM}$ (Hexapur) pH 7,5; $\mathrm{MgCl}_{2} 10 \mathrm{mM}$ (J. T. Baker); $\mathrm{NaCl} 75$ $\mathrm{mM}$ (Synth) e $10 \%$ de glicerol (Synth)] com adição de $0,1 \mathrm{mg} \mathrm{mL}^{-1}$ de lisozima (Fluka Analytical), 0,5 u de DNase (Promega) e $200 \mu \mathrm{L} \mathrm{mL}^{-1}$ PMSF (Sigma)], permanecendo no gelo durante 30 minutos.

Em seguida, as amostras foram sonicadas no equipamento Sonic Dizmembrato Model 500 (Fisher Scientific) com 10 pulsos, sendo 30,0 s pulse on, $59,9 \mathrm{~s}$ pulse off e $30 \%$ de amplitude. O lisado foi centrifugado por 30 minutos a 10000 rpm, a $4 \stackrel{\circ}{\circ}$. As frações solúvel e insolúvel (pellet) foram analisadas por eletroforese em gel de poliacrilamida (SDS-PAGE) 15\%.

\subsection{Protocolos de solubilização da proteína CDK8 obtida em corpos de inclusão e posterior reenovelamento}

\subsubsection{Solubilização pelo trifluoroetanol - TFE}

A CDK8 obtida em corpos de inclusão, foi ressuspendida em tampão de solubilização (50 mM Tris- $\mathrm{HCl} \mathrm{pH}$ 7,5, $3 \mathrm{M}$ ureia, 50\% TFE e $1 \mathrm{mM}$ de DTT), incubada por 2 horas sob agitação. Após centrifugação (10000 rpm/30 min), obtevese a fração sobrenadante e pellet. À fração solúvel foi adicionado tampão de reenovelamento (250 mM Tris- $\mathrm{HCl} \mathrm{pH} 7,5$ e $50 \mathrm{mM} \mathrm{NaCl}$ ) e em seguida, o sobrenadante foi centrifugado $\left(12000 \mathrm{rpm} / 30 \mathrm{~min} / 4^{\circ} \mathrm{C}\right)$ ), obtendo-se assim a fração solúvel e o pellet que foram analisados por eletroforese em gel de poliacrilamida 15\% (UPADHYAY et al., 2016). 


\subsubsection{Solubilização pelo dodecil sulfato de sódio - SDS}

Basicamente, o protocolo descrito por $\mathrm{He}$ e Ohnishi (2017) envolve a desnaturação da proteína com tampão contendo SDS $2 \%$, posterior precipitação a frio $\left(4^{\circ} \mathrm{C}\right)$, e por $\mathrm{KCl}$. A fração solúvel resultante é submetida à cromatografia de afinidade ao $\mathrm{Ni}^{2+}$ a fim de purificar a proteína alvo. $\mathrm{O}$ protocolo original sofreu algumas modificações, a fim de adaptá-lo às características intrínsecas da proteína CDK8.

O pellet, obtido após a indução a $20^{\circ} \mathrm{C}$ com $0,2 \mathrm{mM}$ de IPTG foi lavado três vezes com tampão Hepes $50 \mathrm{mM}$ pH 7,5, e em seguida, solubilizado com SDS $1 \%$, diferentemente da quantidade utilizada por He e Ohnishi (2017). Posteriomente, esta solução contendo SDS $1 \%$ foi submetida à sonicação até que a solução se tornasse clara. Esta solução foi mantida a $4{ }^{\circ} \mathrm{C}$ overnight para precipitação do SDS. Logo após, a solução foi centrifugada $(9000 \mathrm{rpm} / 10 \mathrm{~min})$ e ao sobrenadante foram adicionados $200 \mathrm{mM}$ de $\mathrm{KCl}$ para a remoção do excesso de SDS. Cristais insolúveis de SDS- $\mathrm{KCl}$ foram formados a $4{ }^{\circ} \mathrm{C}$ após 6 horas. Após centrifugação, 0 sobrenadante foi submetido à cromatografia de afinidade em coluna de $\mathrm{Ni}^{2+}$.

\subsection{Purificação da CDK8 utilizando cromatografia de afinidade}

A CDK8-HisTag foi purificada no equipamento Akta purifier utilizando-se coluna de afinidade $\mathrm{Ni}^{2+}$ (HisTrap ${ }^{T M} F F-$ GE Healthcare $-5 \mathrm{~mL}$ ). A amostra contendo a CDK8-HisTag foi centrifugada (9000 rpm/10 min) antes de ser aplicada na coluna. Posteriormente, $10 \mathrm{~mL}$ da amostra foram aplicados na coluna (1 $\left.\mathrm{mL} \mathrm{min}^{-1}\right) \mathrm{com}$ o auxílio do superloop (GE Healthcare $-10 \mathrm{~mL}$ ). A coluna foi condicionada no tampão A (Hepes $50 \mathrm{mM}, \mathrm{NaCl} 150 \mathrm{mM}$, imidazol $10 \mathrm{mM}$, glicerol $10 \%$ ) e a CDK8-HisTag eluída com tampão B (Hepes $50 \mathrm{mM}, \mathrm{NaCl} 150 \mathrm{mM}$, imidazol $300 \mathrm{mM}$ e glicerol $10 \%)$. 


\subsection{Análise da CDK8 por eletroforese bidimensional - 2D}

Este experimento foi realizado no Laboratório de Bioanalítica, Microfabricação e Separações - BioMics, ISQC/USP sob coordenação do Prof. Dr. Emanuel Carrilho.

Para a realização da eletroforese 2D, a CDK8 foi precipitada com acetona a $20{ }^{\circ} \mathrm{C}$ (9 volumes de acetona gelada:1 volume de solução da proteína). Esta solução foi incubada por 16 horas e logo após, a amostra foi centrifugada (14000 rpm, 5 min, $4{ }^{\circ} \mathrm{C}$ ) e o precipitado, solubilizado no tampão de rehidratação [ureia $7 \mathrm{M}$; tioureia $2 \mathrm{M}$; CHAPS 2\%, IPTG 0,5\%; azul de bromofenol 0,002 \%]. Uma solução comercial de DTT (20 mM) foi adicionada ao tampão de rehidratação imediatamente antes do uso. Este processo durou 10 minutos e a solução foi centrifugada (9000 rpm/5 min) para a retirada de possíveis particulados. Foram aplicados $25 \mu \mathrm{L}$ da amostra $(5,5 \mu \mathrm{g} / \mathrm{mL})$ diluídos em $225 \mu \mathrm{L}$ de solução de rehidratação. Em seguida, a fita de $7 \mathrm{~cm}(\mathrm{pH} 3-10)$ foi colocada em contato com as amostras e submersa em óleo mineral por $12 \mathrm{~h}$.

A fita foi colocada no sistema focalizador (Ettan IPGphor - GE), onde foi aplicado o seguinte método: $300 \mathrm{~V}$ até $200 \mathrm{Vh}, 1000$ até $300 \mathrm{Vh}, 5000$ até $4000 \mathrm{Vh}$, 5000 até 1250 Vh. Foram acumulados 5750 Vh no total de 2 h e 45 min. Após a focalização, as fitas foram reequilibradas com $10 \mathrm{~mL}$ de uma solução contendo Tris$\mathrm{HCl} 1,5 \mathrm{~mol} / \mathrm{L} \mathrm{pH} \mathrm{8,8;} \mathrm{ureia} 6 \mathrm{~mol} / \mathrm{L}$; SDS $2 \%$; glicerol $30 \%$ e azul de bromofenol 0,002\% sob agitação por $15 \mathrm{~min}$. Em seguida, as proteínas da fita foram reduzidas após adição de DTT (100 mg:10mL de solução de equilíbrio) e IAA (250 mg:10 mL de solução de equilíbrio).

Para a segunda dimensão, a fita foi inserida no gel de poliacrilamida $15 \%$ junto com um pedaço de papel de filtro contendo $10 \mu \mathrm{L}$ do marcador molecular. Em seguida, foi aplicada uma solução aquecida de agarose $0,5 \%$ para fixar a fita e o papel contendo o padrão de massa molecular. A separação na segunda dimensão (separação por massa molecular) foi realizada aplicando-se 90 V. Após a separação por massa molecular, as bandas do gel foram visualizadas com solução de nitrato de prata. 


\subsection{Determinação da CDK8 por Western Blot}

O imunoensaio por western blot foi realizado no laboratório da Profa. Dra. Dulce Helena Ferreira de Souza, do Departamento de Química da Universidade Federal de São Carlos, UFSCar. Este experimento foi uma das etapas mais importantes do trabalho, pois confirma os resultados obtidos na etapa de expressão heteróloga em E. coli. Foi utilizado um anticorpo primário contra a cauda de histidina presente no $\mathrm{N}$-terminal da CDK8.

Inicialmente as amostras foram aplicadas em SDS-PAGE e em seguida, transferidas para uma membrana de nitrocelulose. Na etapa de transferência utilizou-se um método semi seco com aplicação de um potencial de $25 \mathrm{~V} / 30 \mathrm{~min}$ no equipamento Trans-Blot Turbo Transfer System (BioRad). Em seguida, a membrana foi tingida com Ponceau e então descorada com solução de ácido acético $1 \% \mathrm{e}$ incubada overnight a $4{ }^{\circ} \mathrm{C}$ com uma solução de bloqueio contendo leite em pó desnatado $5 \%$. Após isso, a membrana foi lavada com TBS e encubada por aproximadamente 2 horas com uma mistura de anticorpos primário e secundário e por fim, a membrana foi encubada com solução reveladora de BCIP/NBT (Sigma Aldrich).

\subsection{Caracterização estrutural}

\subsubsection{Espectropolarimetria de dicroísmo circular}

O espectro de dicroísmo circular foi obtido à temperatura ambiente, utilizando atmosfera inerte de nitrogênio no equipamento Jasco J-815 CD Spectrophotometer da Central de Análises Químicas Instrumentais - CAQUI do IQSC-USP.

Os dados obtidos através da subtração da absorção de luz circularmente polarizada à direita e à esquerda estão em miligraus e foram normalizados para a elipticidade molar residual através da seguinte equação (OLSEN, 1990):

$$
[\Theta]=\frac{\Theta \lambda \times M M}{10 \times l \times n \times c g}
$$

Onde $\theta \lambda$ é o sinal de dicroísmo circular obtido em miligraus; $M M$ é a massa molar da proteína em $\mathrm{g} / \mathrm{mol}$, l é o caminho óptico, em centímetros, $n$ é o número de resíduos de aminoácidos da proteína e $c_{g}$ é a concentração da mesma em mg/mL. 
A CDK8 foi diluída a partir de uma solução estoque de $7,69 \mathrm{mg} / \mathrm{mL}$ para a concentração de $0,017 \mathrm{mg} / \mathrm{mL}$. A diluição foi realizada em tampão [Hepes $(50 \mathrm{mM}$ $\mathrm{pH} 7,5) \mathrm{NaCl}(150 \mathrm{mM})]$. Esta solução diluída foi submetida à espectropolarimetria de $C D$ como forma de estimar os elementos de estrutura secundária da proteína. Foi utilizada uma cubeta de quartzo com caminho ótico de $1 \mathrm{~mm}$ e os espectros de CD foram coletados com 30 acumulativas e tempo de resposta de 1 segundo.

A predição das quantidades de elementos de estrutura secundária foi realizada através de metodologias estatísticas que fazem comparações do espectro de CD da proteína em estudo com o espectro de proteínas que apresentam estrutura secundária conhecida, determinada em solução aquosa e por cristalografia de raios X (YANG, 1996). Cada elemento de estrutura secundária possui sinais específicos no espectro de CD que permitem identificá-los após a deconvolução do espectro, feita através do software CDNN (version 2: Bioinformatik.biochemtech.unihalle.dee/cdnn) deconvolution. Este software permite a inserção do espectro de CD da proteína alvo e mediante comparações com espectros de proteínas existentes em seus bancos de dados, fornece as quantidades de elementos de estrutura secundária da amostra em questão (BÖHM; MUHR; JAENICKE, 1992).

\subsubsection{Fluorescência}

O espectro de fluorescência foi obtido no equipamento F4500 Hitachi Fluorescence Spectrophotometer da Central de Análises Químicas Instrumentais CAQUI do IQSC-USP. Foi utilizada uma cubeta de caminho ótico $1 \mathrm{~cm}$ e abertura da fenda de excitação de $1,5 \mathrm{~nm}$ e abertura da fenda de emissão de $3 \mathrm{~nm}$.

O espectro de emissão da CDK8 foi obtido em solução contendo tampão Hepes [(50 mM) pH 7,5; $\mathrm{NaCl}(150 \mathrm{mM})]$. Foi usado o comprimento de onda máximo de excitação de $280 \mathrm{~nm}$, região na qual os resíduos de aminoácidos Tyr e Trp absorvem luz, emitindo em 300-360 nm (LAKOWICZ, 2007). 


\section{RESULTADOS E DISCUSSÃO}

\subsection{Amplificação e clonagem do cDNA da CDK8 a partir do plasmídeo recombinante pET28a::cdk8 sintético e de bibliotecas de cDNA}

A partir de análises por bioinformática, podemos observar o grau de desordem da proteína CDK8 no mapa de estrutura secundária (Figura 18). Neste mapa, as regiões desordenadas estão indicadas em vermelho. Podemos observar em lilás, a região correspondente às hélices $\alpha \mathrm{e} e \mathrm{em}$ amarelo, a região correspondente às folhas $\beta$. A Figura 19 mostra que há uma pequena região desordenada no início da sequência de aminoácidos da proteína e que se torna mais acentuada no final. Podemos perceber que quanto mais a curva se aproxima do valor unitário, mais desordenada é aquela região da sequência.

$\mathrm{Na}$ tentativa de minimizar problemas no enovelamento da proteína, e consequente solubilidade na etapa de expressão, optou-se por trabalhar apenas com o domínio quinase da CDK8, conservada entre todas as CDKs (região que inclui o sítio ativo da enzima).

A partir da busca de dados no GenBank (NCBI), número de acesso gi:4502744 (Figura 20), a sequência resultante com as modificações mencionadas anteriormente possui 990 pb (Figura 21). Com esta sequência realizaram-se testes de amplificação e clonagem no vetor de propagação pCR-Blunt e no vetor de expressão pET28a. 
Figura 18 - Mapa de elementos de estrutura secundária da proteína CDK8, mostrando as regiões desordenadas (quadrinhos em vermelho) no $\mathrm{N}$ - e C-terminais. Quadrinhos em lilás correspondem às regiões de hélices $\alpha$ e quadrinhos em amarelo, regiões de folhas $\beta$.
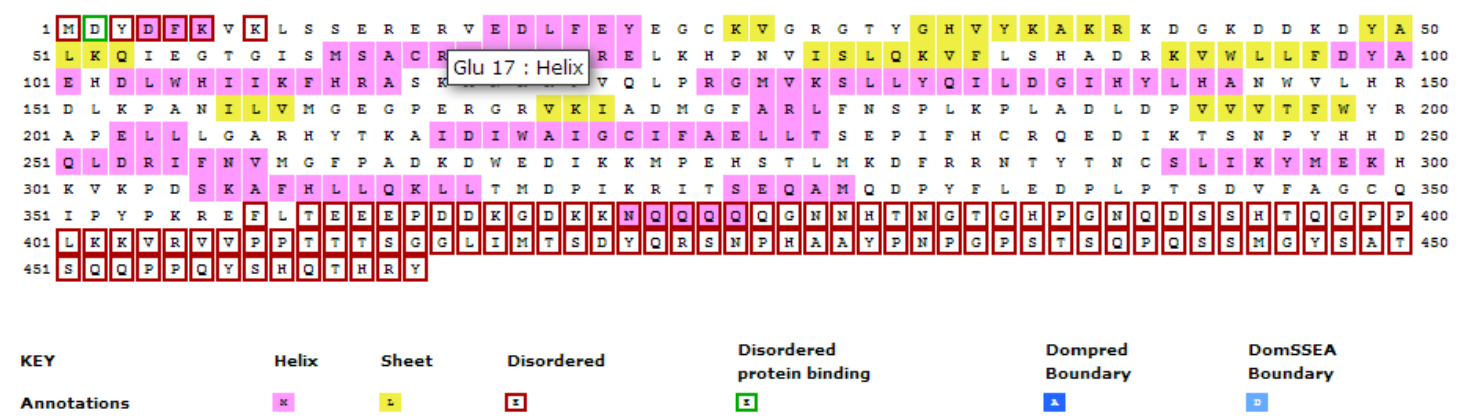

Fonte: Psipred Protein v. 3.3.

Figura 19 - Gráfico do perfil de desordem intrínseca da proteína CDK8. Os últimos 150 resíduos de aminoácidos da cadeia polipeptídica possuem score em torno de 1 , demonstrando região de alta desordem.

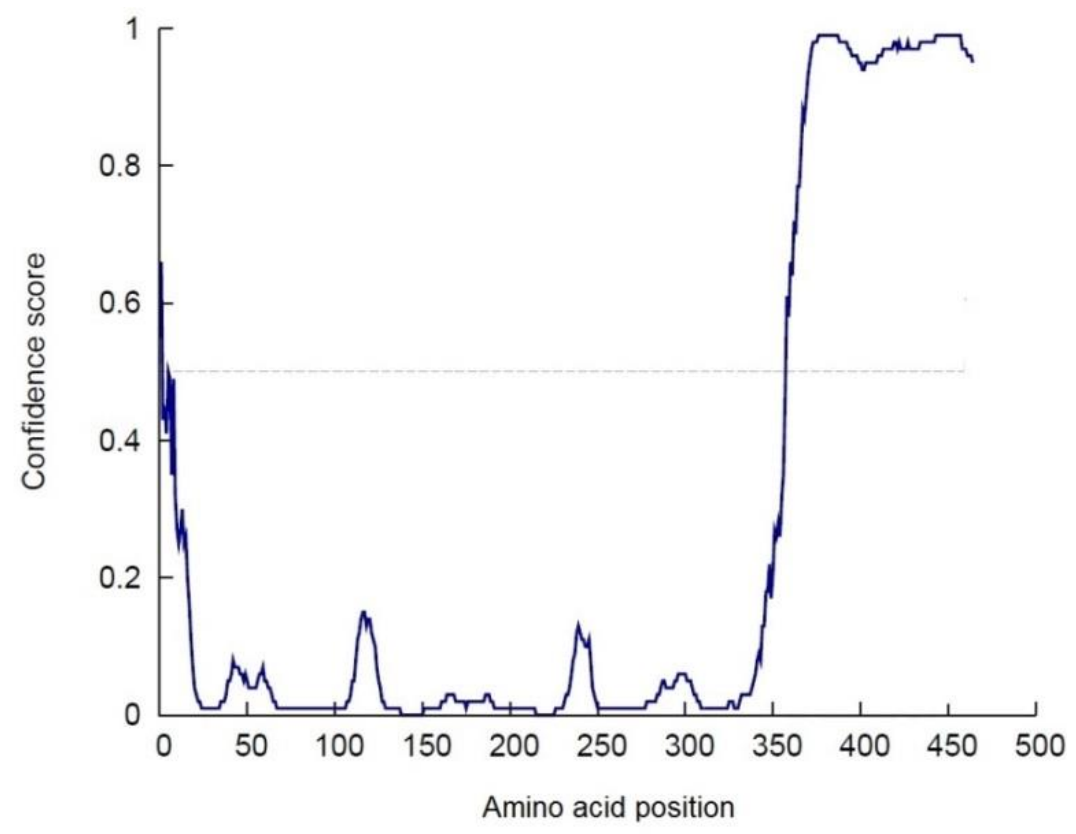

Fonte: Psipred Protein v. 3.3. 
Figura 20 - Sequência de cDNA da CDK8. Em vermelho, estão destacados os nucleotídeos correspondentes às regiões desordenadas que foram removidos.

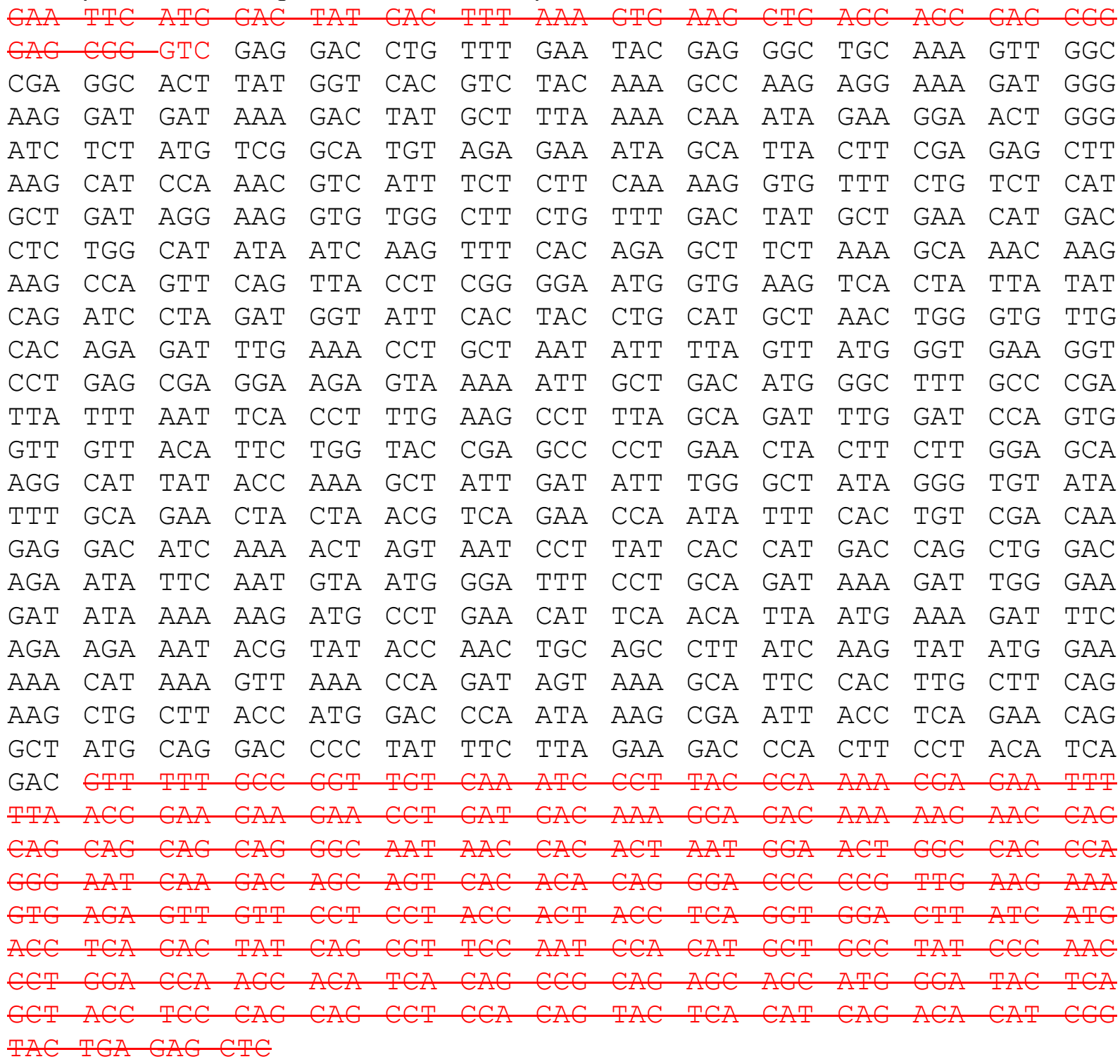

Fonte: http://nihserver.mbi.ucla.edu/RACC/. 
Figura 21 - Sequência do cDNA que codifica a CDK8 sem os nucleotídeos correspondentes à região desordenada da proteína.

ATGGAGGACCTGTTTGAATACGAGGGCTGCAAAGTTGGCCGAGGCACTTATGGTCACGTCTACAAAGCCAAG AGGAAAGATGGGAAGGATGATAAAGACTATGCTTTAAAACAAATAGAAGGAACTGGGATCTCTATGTCGGCA TGTAGAGAAATAGCATTACTTCGAGAGCTTAAGCATCCAAACGTCATTTCTCTTCAAAAGGTGTTTCTGTCTCAT GCTGATAGGAAGGTGTGGCTTCTGTTTGACTATGCTGAACATGACCTCTGGCATATAATCAAGTTTCACAGAGC TTCTAAAGCAAACAAGAAGCCAGTTCAGTTACCTCGGGGAATGGTGAAGTCACTATTATATCAGATCCTAGAT GGTATTCACTACCTGCATGCTAACTGGGTGTTGCACAGAGATTTGAAACCTGCTAATATTTTAGTTATGGGTGA AGGTCCTGAGCGAGGAAGAGTAAAAATTGCTGACATGGGCTTTGCCCGATTATTTAATTCACCTTTGAAGCCTT TAGCAGATTTGGATCCAGTGGTTGTTACATTCTGGTACCGAGCCCCTGAACTACTTCTTGGAGCAAGGCATTAT ACCAAAGCTATTGATATTTGGGCTATAGGGTGTATATTTGCAGAACTACTAACGTCAGAACCAATATTTCACTG TCGACAAGAGGACATCAAAACTAGTAATCCTTATCACCATGACCAGCTGGACAGAATATTCAATGTAATGGGA TTTCCTGCAGATAAAGATTGGGAAGATATAAAAAAGATGCCTGAACATTCAACATTAATGAAAGATTTCAGAA GAAATACGTATACCAACTGCAGCCTTATCAAGTATATGGAAAAACATAAAGTTAAACCAGATAGTAAAGCATT CCACTTGCTTCAGAAGCTGCTTACCATGGACCCAATAAAGCGAATTACCTCAGAACAGGCTATGCAGGACCCCT ATTTCTTAGAAGACCCACTTCCTACATCAGACTGA

Fonte: Autoria própria.

A Tabela 17 sintetiza os resultados obtidos após a PCR, confirmados por eletroforese em gel de agarose $0,8 \%$. Tanto o DNA sintético quanto a biblioteca de cDNA de cérebro fetal tiveram resultado na amplificação, o mesmo não ocorreu para a biblioteca de cDNA de leucócitos.

Tabela 17 - Resultado da amplificação pela PCR utilizando como moldes o gene sintético, biblioteca de cDNA de cérebro fetal e leucócitos.

\begin{tabular}{|c|c|}
\hline PCR & RESULTADO \\
\hline Gene sintético (Epoch Life Science) & Positivo* \\
\hline Biblioteca de cDNA de cérebro fetal & Positivo** \\
\hline Biblioteca de cDNA de leucócito* & Negativo*** \\
\hline
\end{tabular}

${ }^{*}$ Amplificou em todas as temperaturas testadas $\left(59,7 ; 60,9 ; 62,7 ; 65\right.$ e $\left.67^{\circ} \mathrm{C}\right)$.

**Amplificou em todas as temperaturas testadas $(59,4 ; 60,9 ; 65,8 ; 67,4)$.

${ }^{* * *}$ Não amplificou nas temperaturas testadas $(59,4 ; 60,9 ; 65,8 ; 67,4)$.

Os testes de clivagem com as enzimas Ndel e Hindll, mostraram que não houve a liberação do inserto em 990 pb, após a ligação tanto no vetor de propagação pCR-Blunt, quanto no vetor de expressão pET28a, o que sugeriu que a ligação não foi eficiente, ou que apenas uma enzima clivou o plasmídeo, linearizando-o. 
A partir do cDNA e do vetor de expressão (pET28a) previamente digeridos, realizou-se nova reação de ligação. Após a transformação em células DH5a, XL-1 Blue quimicamente competentes e DH5a eletrocompetentes, observou-se que poucas colônias cresceram nas placas. Os valores das concentrações dos produtos da ligação, após a purificação, encontram-se na Tabela 18.

Tabela 18 - Valores das concentrações dos produtos de ligação transformados em diferentes cepas de E. coli.

\begin{tabular}{cc}
\hline Cepa $^{*}$ & Concentração $(\mathrm{ng} / \mu \mathrm{L})$ \\
\hline XL1-blue C2 & 5,42 \\
XL1-blue B2 & 3,92 \\
XL1-blue A2 & 4,59 \\
DH5a B & 331,65 \\
Eletro A1 & 1,78 \\
DH5a A & 255,67
\end{tabular}

*As letras A, A1, A2, B, B2 e C2 representam diferentes colônias. Fonte: Autoria própria.

Apesar das amostras DH5a A $(255,77 \mathrm{ng} / \mu \mathrm{L})$ DH5a B $(331,65 \mathrm{ng} / \mu \mathrm{L})$ possuírem concentrações relativamente elevadas, não apresentaram resultado positivo na análise de restrição com as enzimas Ndel e Hindlll. Para concluir o resultado, as amostras DH5a A e DH5a B (de maiores concentrações) foram submetidas ao sequenciamento. No entanto, a análise do cromatograma obtido não mostrou a presença do inserto, mas somente do vetor pET28a, e portanto, o recombinante não foi de fato obtido.

Tendo em vista que tivemos problemas na etapa de ligação ao vetor de expressão, um novo primer foi desenhado designado pet $F w$, pois este anelaria a um segmento do $\mathrm{pET} 28 \mathrm{a}$ do recombinante sintético pET28a::cdk8, e nova amplificação por PCR seria alcançada, porém dímeros de primers foram formados, não havendo amplificação.

Outra fonte de DNA foi utilizada na tentativa de obter o recombinante, a biblioteca de cDNA de cérebro fetal, porém apresentou os mesmos problemas durante a análise de restrição. A análise do sequenciamento realizado nesta etapa 
resultou em uma similaridade de $97 \%$, que pode ser observado pelo alinhamento das sequências (Figura 22). Observa-se deleções nas terminações 5'e 3'do DNA sequenciado, que justifica o insucesso na obtenção do recombinante pET28a::cdk8. Estas deleções provavelmente foram originadas na etapa de amplificação. Deleções internas também foram observadas.

Figura 22 - Alinhamento das sequências do cDNA da CDK8 obtido na PCR contra a referência (gi:4502744).

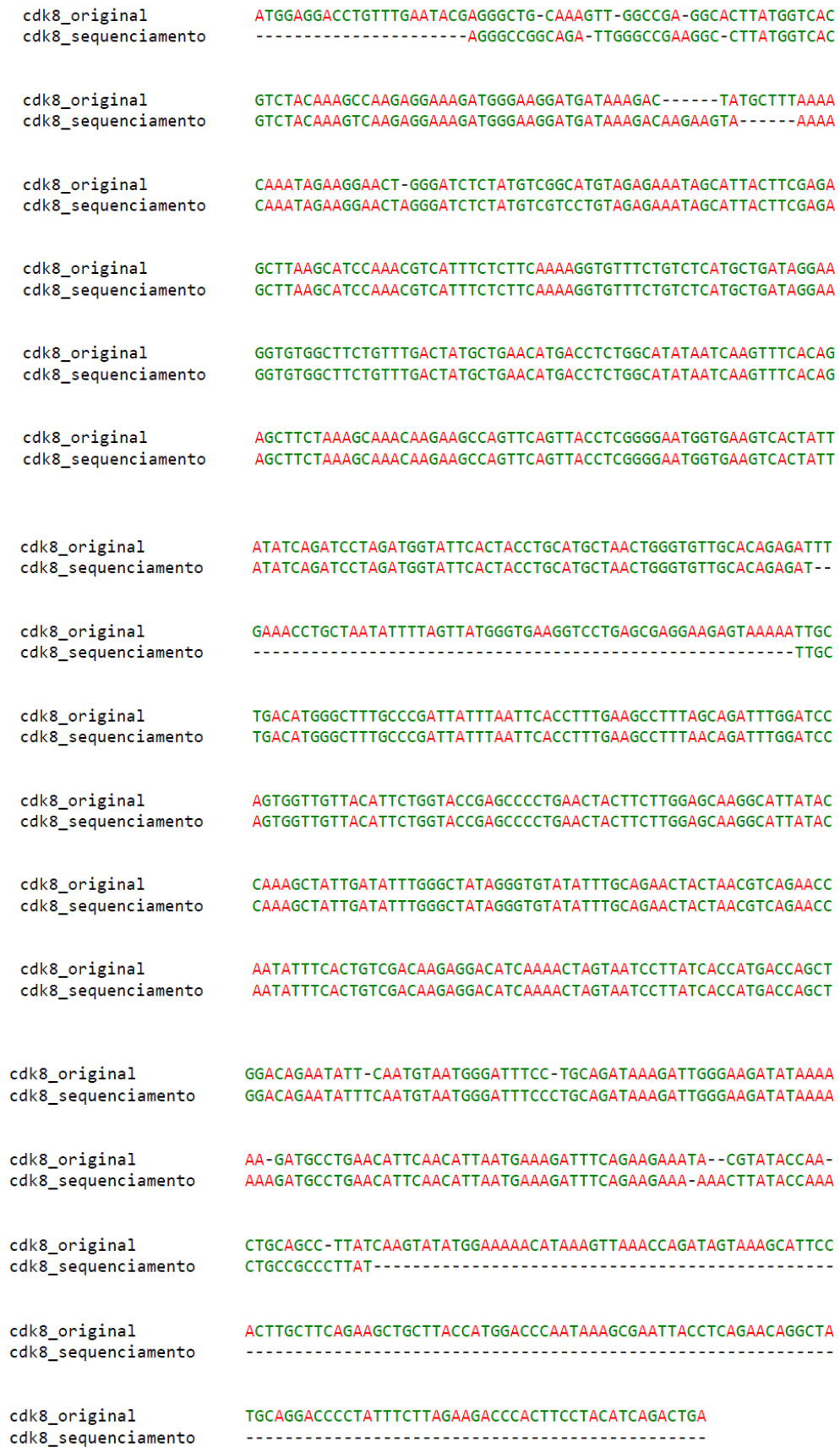

Fonte: http://www.ebi.ac.uk/Tools/msa/kalign/. 


\subsection{Obtenção do recombinante pET28a::cdk8 $\Delta$}

Baseado nos resultados negativos obtidos até então, nova análise da sequência de cDNA da CDK8 depositada no GenBank (NCBI) foi realizada, com o objetivo de realizar nova síntese do DNA e conseguir a clonagem e expressão da CDK8.

Na Figura 23, está representada a sequência que codifica a proteína CDK8 na presença e ausência dos códons raros. Os códons raros foram substituídos porque poderiam dificultar as etapas de expressão em sistema bacteriano. O gene sintético obtido (Invitrogen) foi ligado diretamente ao vetor pET28a, resultando no recombinante pET28a::cdk8 $\Delta$, que apresentou uma sequência codificante para a proteína CDK8 sem a região desordenada do C-terminal (conforme observado na Figura 18), além da ausência de códons raros.

O teste de restrição do recombinante pET28a::cdk8 foi bem sucedido, uma vez que foi possível a observação em gel de agarose $0,8 \%$, representado na Figura 24, de duas bandas: uma em, aproximadamente, 6000 pb e a segunda em, aproximadamente, $1077 \mathrm{pb}$, representando, respectivamente, o vetor linearizado pET28a e o fragmento de cDNA.

A análise do sequenciamento, realizada com o auxílio da ferramenta BLAST (Basic Local Alignment Search Tool -http://blast.ncbi.nlm.nih.gov/Blast.cgi), resultou em uma similaridade com o DNA de interesse de 98\%. Uma segunda análise feita com o auxílio da ferramenta Kalign (http://www.ebi.ac.uk/Tools/msa/kalign/) permitiu a visualização do alinhamento entre a sequência do DNA de referência, depositada no NCBI, e aquela obtida no sequenciamento, conforme ilustrado na Figura 25. As análises demonstraram a integridade do DNA plasmidial, uma vez que não houve ocorrências de mutações e deleções significativas. 
Figura 23 - Sequência do cDNA codificante da proteína CDK8 $\Delta$. A) sequência com códons raros destacados em vermelho. B) sequência sem os códons raros em E. coli.

\section{A}

Atg GAg GAC CTG tTt GAA TAC GAg GgC TGC AAA GTt GGC CGA GGC ACt TAt GGT CAC GTC TAC AAA GCC AAg AgG AAA GAT GgG AAg GAT GAT AAA GAC TAt GCT tTA AAA CAA ATA GAA GgA ACt GgG ATC tCt ATG TCG GCA TGT AGA GAA ATA GCA TTA CTT CGA GAg CTT AAg CAT CCA AAC GTC ATT TCT CTT CAA AAg GTG

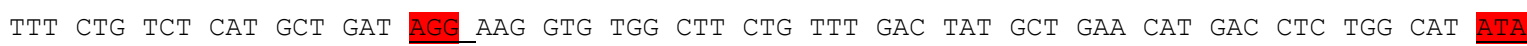
AtC AAg tTT CAC AGA GCT TCt AAA GCA AAC AAg AAg CCA GTT CAg tTA CCT CGg GGA Atg gtg AAg tCA CTA TTA TAT CAg ATC CTA GAT Ggt ATT CAC TAC CTG CAT GCT AAC TGg GTG TTG CAC AgA GAT TTG AAA CCT GCT AAT ATT TTA GTT ATG GGT GAA GGT CCT GAg CGA GGA AGA GTA AAA ATT GCT GAC ATG GGC TTT GCC CGA TTA TTT AAT TCA CCT TTG AAg CCT tTA GCA GAT TTG GAT CCA GTG GTT GTT ACA tTC tGg TAC CGA GCC CCT GAA CTA CTT CTT GGA GCA AGG CAT TAT ACC AAA GCT ATt GAT ATt TGg GCt ATA GgG TGT ATA TTT GCA GAA CTA CTA ACG TCA GAA CCA ATA TTT CAC TGT CGA CAA GAg GAC ATC AAA ACT Agt AAT CCT TAT CAC CAT GAC CAG CTG GAC AGA ATA TTC AAT GTA ATg GGA TTT CCT GCA GAT AAA GAT TGg GAA GAT ATA AAA AAg ATG CCT GAA CAT TCA ACA TTA ATG AAA GAT TTC AGA AGA AAt ACG TAt ACC AAC TGC AGC CTT ATC AAG TAT ATG GAA AAA CAT AAA GTT AAA CCA GAT AGT AAA GCA TTC CAC TTG CTT CAG AAG Ctg CTT ACC ATG GAC CCA ATA AAg CGA AtT ACC TCA GAA CAg GCT Atg CAg GAC CCC tAt tTC tTA GAA GAC CCA CTT CCT ACA TCA GAC TGA

B

AgA AgA CAT ATG GAC TAT GAC TTT AAg GTA AAA tTG AGC TCC GAg CGT GAg CGg GTg GAg GAT tTG tTC GAg TAT GAg GGg TGT AAg GTG GGg CGT GGC ACG TAC GGg CAC GTA TAC AAA GCG AAA CGC AAA GAC GGG

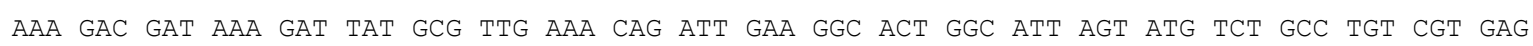
ATC GCA CTG CTT CGT GAA CTT AAA CAC CCG AAC GTG ATC AgT tTA CAg AAA GTA tTC CTG Agt CAT GCT GAT CGC AAg GTC TGG CTG TTG TtT GAT TAC GCG GAg CAC GAT CTG TGg CAT ATt ATt AAA tTt CAt CGC GCC TCG AAA GCG AAC AAA AAA CCG GTG CAg CTG CCG CGT GGA ATg GTg AAA TCA CTG CTG TAC CAg ATT CTT GAT GGC ATT CAT TAT CTC CAC GCC AAC TGG GTC CTG CAT CGC GAT TTG AAA CCA GCA AAC AtT CTC GTA ATG GGC GAg GGA CCG GAg CGT GGT CGC GTG AAA ATC GCA GAT Atg GGC TTC GCG CGC CTT TTC AAC AGC CCG TTG AAA CCT TTG GCA GAT CTG GAT CCA GTG GTC GTA ACC TTT TGg tAt CGT GCt CCG GAg tTG CTG TTA GGT GCG CGC CAT TAC ACt AAA GCG ATT GAT ATC TGG GCA ATC GGA TGC ATC tTt GCC GAA CTG CTG ACC AGC GAg CCT ATT TTC CAT TGC CGT CAg GAg GAT ATC AAA ACC AGC AAt CCG TAC CAC CAC GAT

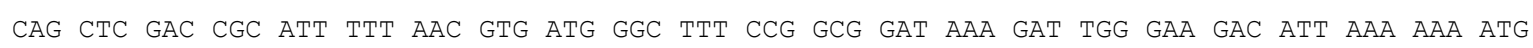

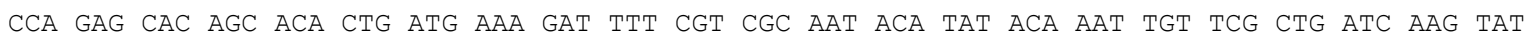
ATG GAA AAA CAT AAg GTG AAg CCT GAT TCG AAg GCA TTC CAT CTT CTG CAG AAG TTA CTG ACC ATG GAT CCA ATC AAA CGT ATt ACT Agt GAA CAg GCG ATg CAg GAC CCG TAT tTt Ctg GAA GAC CCA Ctg CCG ACC AGT GAT GTT TTT GCG GGC TGC CAA ATT TAA GAA TTC AGA AGA

(Fonte: http://nihserver.mbi.ucla.edu/RACC/). 
Figura 24 - Gel de agarose 0,8\% mostrando o produto da clivagem do recombinante pEt28a::cdk8 $\Delta$. A banda em 1000 pb é referente ao cDNA da CDK8 $\Delta$.

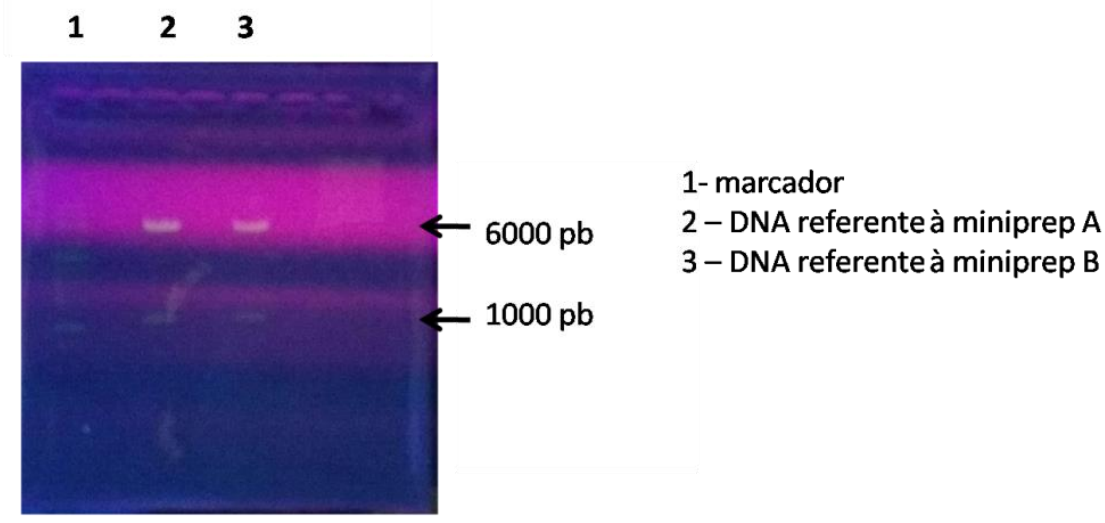

(Fonte: Autoria própria).

Figura 25 - Análise do sequenciamento do plasmídeo recombinante. A sequência com a identificação cdk8 é a referência. Nas caixas em vermelho estão os códons de iniciação e terminação.

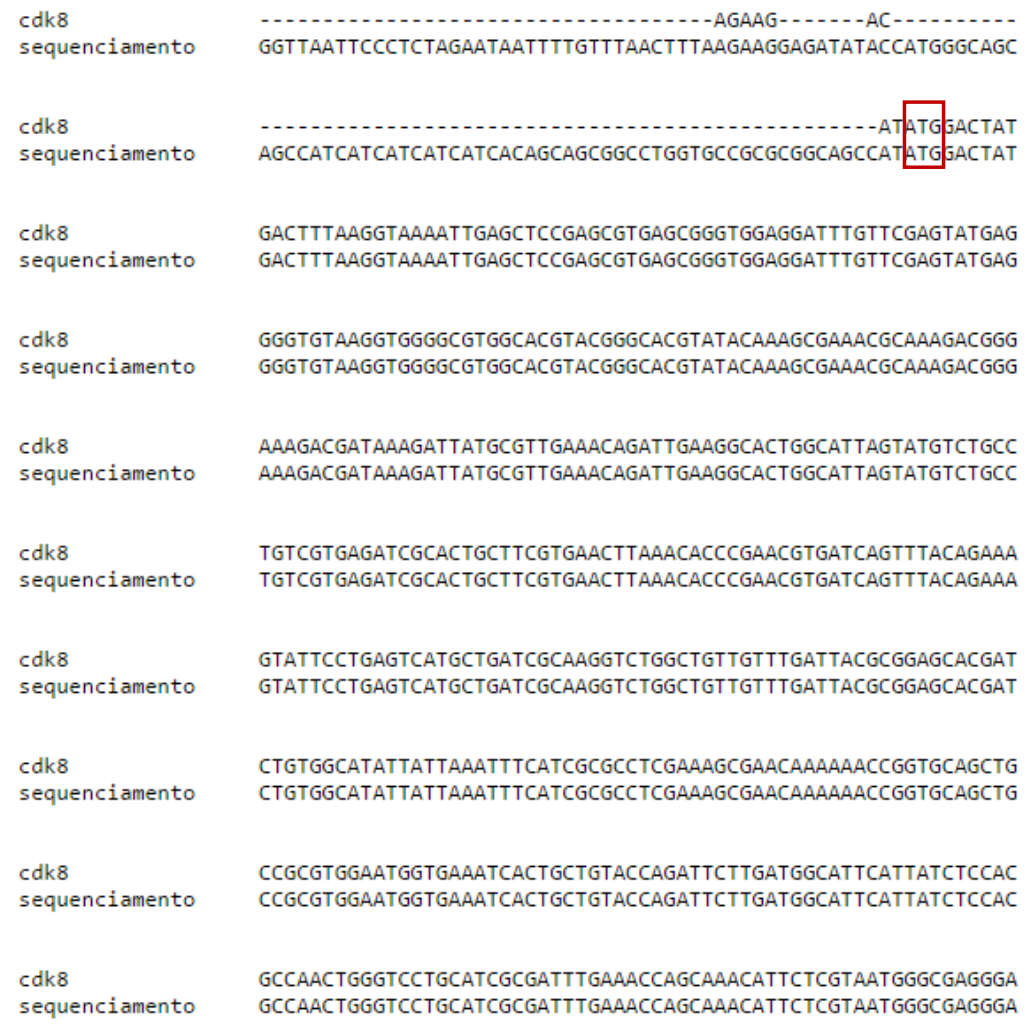




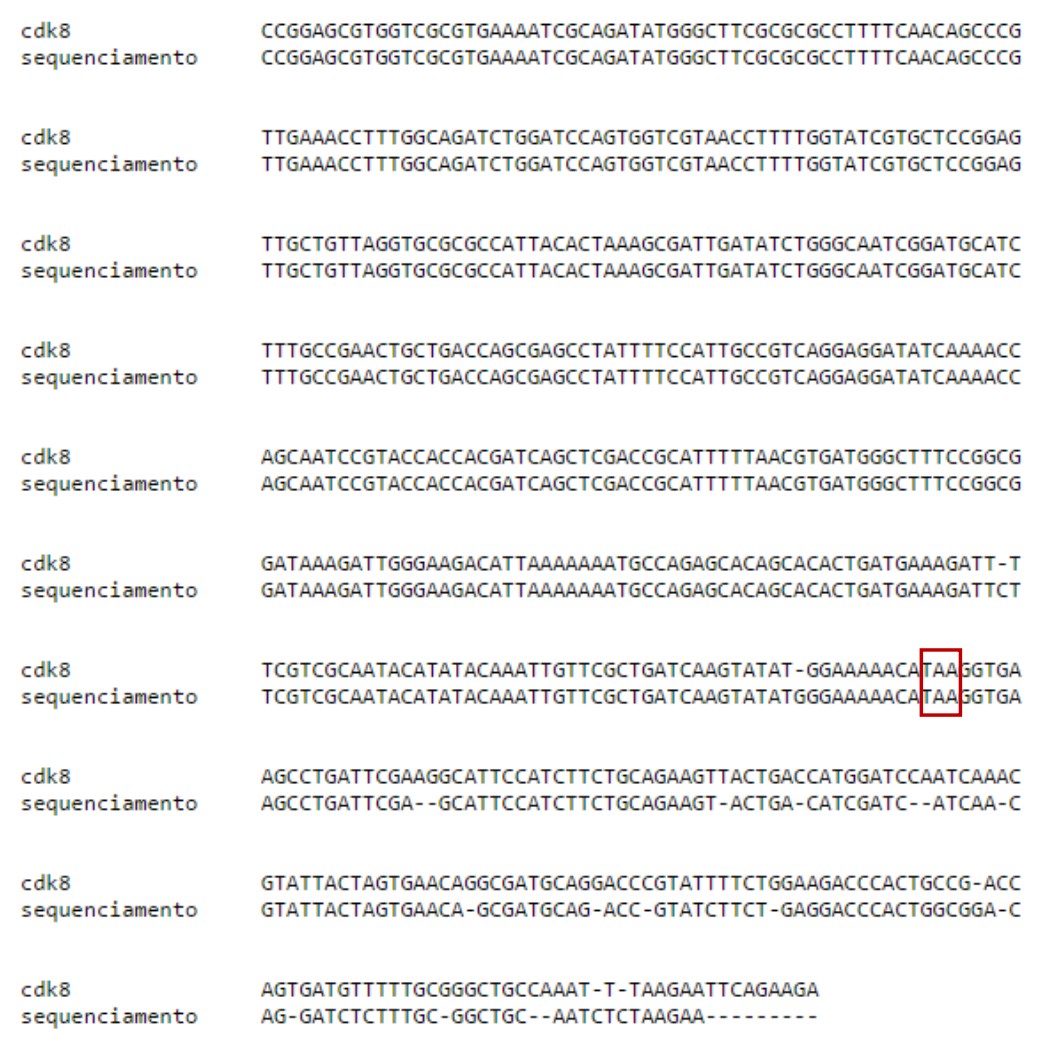

(Fonte: Multiple Sequence Alignment - Kalign).

\subsection{Expressão da proteína CDK8D-HisTag em E. coli}

Após verificar que a temperatura de $20^{\circ} \mathrm{C}$, comparada com a de $37^{\circ} \mathrm{C}$, foi mais efetiva para a expressão do recombinante pET28a::cdk8 $\Delta$, utilizando a cepa de expressão Rosetta(DE3), optou-se por diminuir a temperatura para $18^{\circ} \mathrm{C}$ na tentativa de melhorar ainda mais o padrão de expressão da CDK8, principalmente na fração solúvel do lisado.

Conforme mostrado no gel SDS-PAGE 15\% da Figura 26, os padrões de expressão foram bem semelhantes nas duas temperaturas $\left(18^{\circ} \mathrm{C}\right.$ e $\left.20^{\circ} \mathrm{C}\right)$, com predominância da proteína CDK8 no pellet, então optou-se por utilizar a temperatura de $20^{\circ} \mathrm{C}$ nos experimentos seguintes. A fim de otimizar as condições de expressão, foram testadas variações do meio de cultura líquido, mantendo a temperatura constante (Figuras 27 - 29). Utilizou-se tanto o meio LB (Luria Bertani) quanto um meio de composição semelhante ao SOB (Super Optimal Broth), conveniente para a superexpressão de proteínas. Além de possuir o dobro de conteúdo de triptona, este meio alternativo, possui $15 \mathrm{mmol} / \mathrm{L}$ de $\mathrm{MgCl}_{2}$. Avaliou-se a variação da concentração 
de IPTG de 0,2 - $1 \mathrm{mM}$ e o tempo de indução de 1 hora até 4 horas utilizando o meio LB (Fig. 27a e 27b). Variando a concentração de indutor observou-se que não houve diferenças significativas para um tempo total de indução de 4 horas (Fig. 27a). Com relação à variação do tempo de indução, observou-se que o tempo de 1 a 4 horas não foi suficiente para produzir a proteína tanto na fração solúvel do lisado quanto no pellet, utilizando o meio LB (Fig. 27b).

Analisando as Figuras 28a e 28b, pode-se observar que o meio otimizado na concentração de 0,2 mM de IPTG, melhorou o padrão de expressão da CDK8, embora a proteína, nestas condições, esteja predominantemente sendo produzida em corpos de inclusão. O tempo de indução, utilizando o meio otimizado foi melhor quando a expressão foi feita overnight, visto que aumentou a fração da proteína solúvel (Figura 29).

Figura 26 - SDS-PAGE 15\% mostrando o padrão de expressão da CDK8 $\Delta$ a 18 e $20^{\circ} \mathrm{C}$.

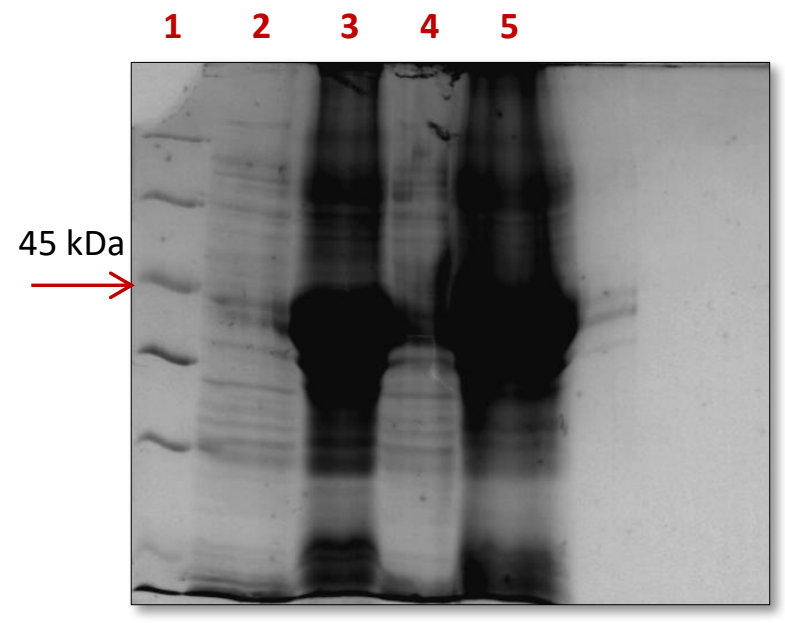

1) Marcador Unstained Protein Marker (Thermo Scientific)

2) Sobrenadante do lisado $\left(20^{\circ} \mathrm{C}\right)$

3) Pellet do lisado $\left(20^{\circ} \mathrm{C}\right)$

4) Sobrenadante do lisado $\left(18^{\circ} \mathrm{C}\right)$

5) Pellet do lisado $\left(18^{\circ} \mathrm{C}\right)$

Fonte: Autoria própria. 
Figura 27 - SDS-PAGE 15\% mostrando a expressão da CDK8 $\Delta$ em diferentes concentrações de indutor (a) e diferentes tempos de indução (b) utilizando 0,2 mM de IPTG em meio LB.

a)

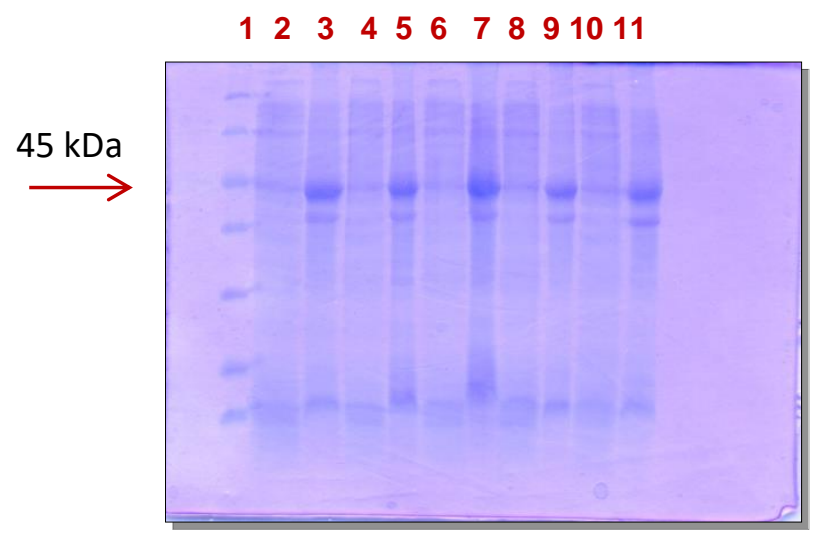

1) Marcador Protein Unstained Marker (Thermo Scientific)

2) Sobrenadante (IPTG $0,2 \mathrm{mM}$ )

3) Pellet (IPTG 0,2 mM)

4) Sobrenadante (IPTG $0,4 \mathrm{mM}$ )

5) Pellet (IPTG 0,4 mM)

6) Sobrenadante (IPTG $0,6 \mathrm{mM}$ )

7) Pellet (IPTG 0,6 mM)

8) Sobrenadante (IPTG $0,8 \mathrm{mM}$ )

9) Pellet (IPTG $0,8 \mathrm{mM}$ )

10) Sobrenadante (IPTG $1 \mathrm{mM}$ )

11) Pellet (IPTG $1 \mathrm{mM}$ )

b)

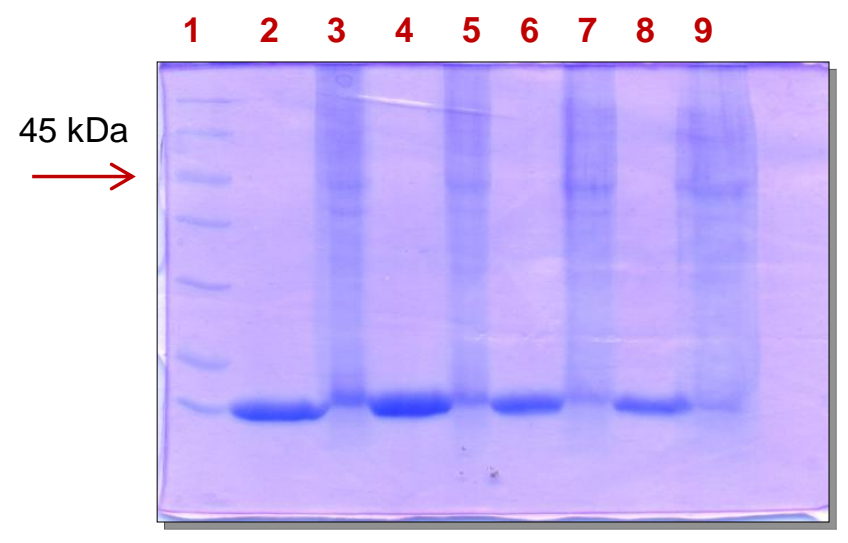

1) Marcador Protein Unstained Marker (Thermo Scientific)

2) Sobrenadante (1 $\mathrm{h}$ de indução)

3) Pellet ( $1 \mathrm{~h}$ de indução)

4) Sobrenadante ( $2 \mathrm{~h}$ de indução)

5) pellet ( $2 \mathrm{~h}$ de indução)

6) Sobrenadante ( $3 \mathrm{~h}$ de indução)

7) Pellet ( $3 \mathrm{~h}$ de indução)

8) Sobrenadante (4 $\mathrm{h}$ de indução)

9) Pellet (4 $\mathrm{h}$ de indução)

Fonte: Autoria própria. 
Figura 28 - SDS-PAGE 15\% mostrando o padrão de expressão da CDK8 $\Delta$ em diferentes tempos de indução (1h, 2h, 3h, 4h e overnight) com 0,2 mM de IPTG utilizando o meio otimizado.

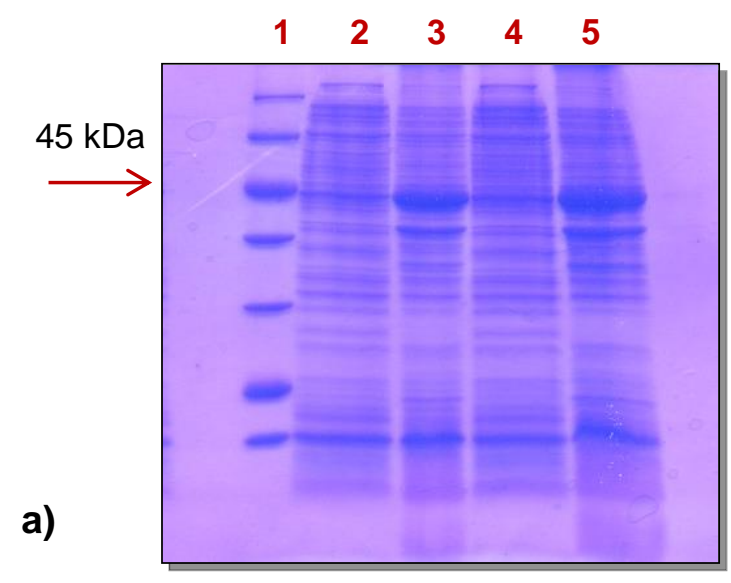

10) Marcador Protein Unstained Marker (Thermo Scientific)

11) Sobrenadante meio otimizado (1h)

12) Pellet meio otimizado (1h)

13) Sobrenadante meio otimizado (2h)

14) Pellet meio otimizado (2h)

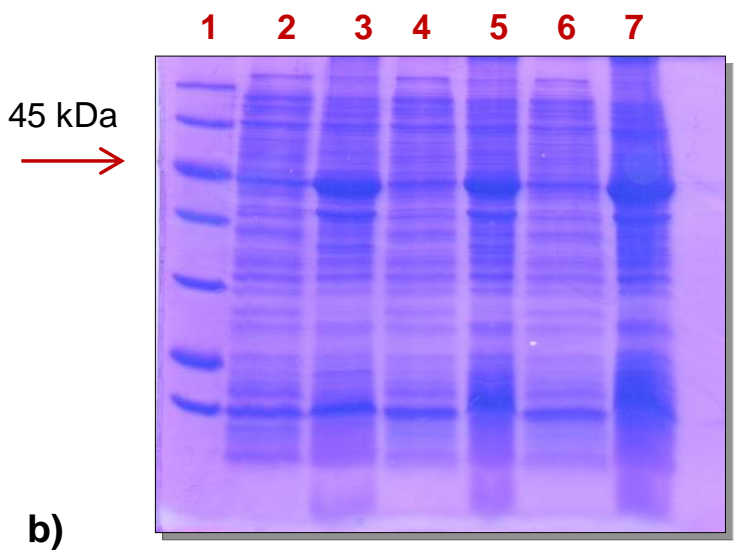

1) Marcador Protein Unstained Marker (Thermo Scientific)

2) Sobrenadante meio otimizado (3h)

3) Pellet meio otimizado (3h)

4) Sobrenadante meio otimizado (4h)

5) Pellet meio otimizado (4h)

6) Sobrenadante meio otimizado (overnight)

7) Pellet meio otimizado (overnight)

Fonte: autoria própria.

Figura 29 - SDS-PAGE 15\% mostrando o padrão de expressão da CDK8 $\Delta$ em meio LB e meio otimizado a $20^{\circ} \mathrm{C}$ com $0,2 \mathrm{mM}$ de IPTG, overnight.

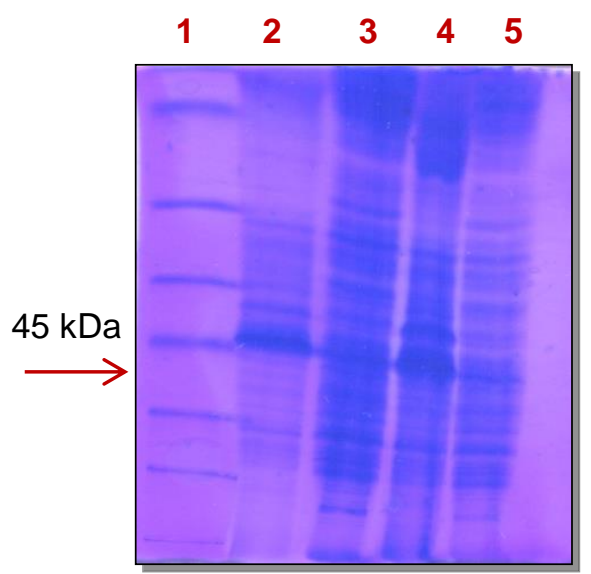

1) Marcador Protein Unstained Marker (Thermo Scientific)

2) Sobrenadante LB (overnight)

3) Pellet meio LB (overnight)

4) Sobrenadante meio otimizado (overnight)

5) Pellet meio otimizado (overnight)

Fonte: Autoria própria. 
Conforme pôde ser observado nos géis das figuras 26 a 29, existem duas bandas que aparecem muito próximas de $45 \mathrm{kDa}$, levantando a dúvida sobre qual dessas seria referente a proteína CDK8 8 , já que esta está fusionada a uma cauda de poli-histidina, o que pode causar uma migração diferencial no gel de poliacrilamida. A fim de nos certificarmos qual seria a banda referente à superexpressão, fez-se um experimento de expressão utilizando um grupo controle que não continha o plasmídeo de interesse. Sendo assim, seriam expressas somente as proteínas da cepa Rosetta(DE3). Este resultado está apresentado no gel SDS-PAGE da Figura 30. É possível observar nas duas últimas canaletas ( 6 e 7) que a banda em aproximadamente $43 \mathrm{kDa}$ (indicada pela seta), não aparece, logo, podemos atribuir esta banda a proteína recombinante CDK84-HisTag e não a uma proteína da própria cepa Rosetta(DE3).

Figura 30 - SDS-PAGE 15\% mostrando a superexpressão da CDK8 em células transformadas de Rosetta(DE3) e a expressão do grupo controle (não transformado).

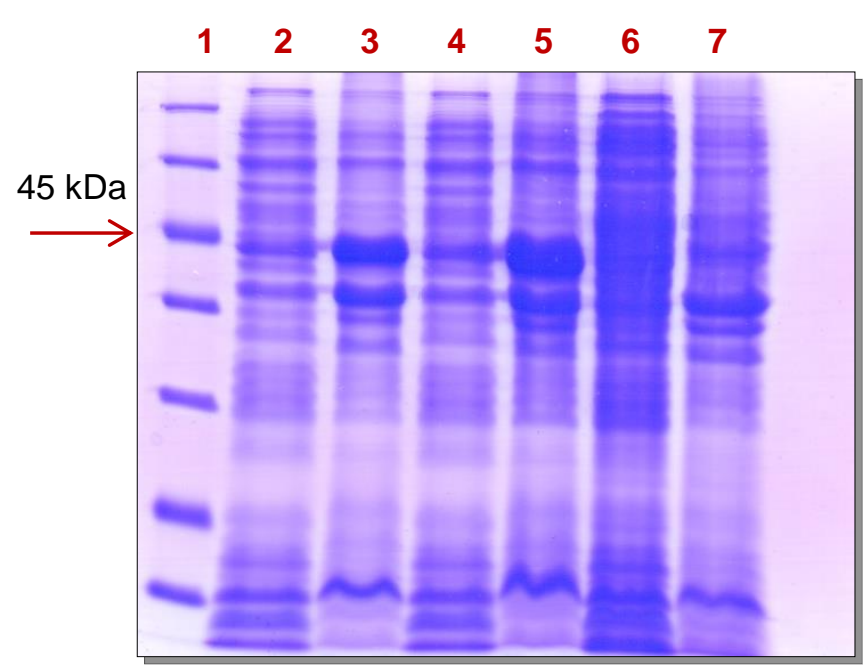

Fonte: Autoria própria.
1) Marcador Protein Unstained Marker

2) Sobrenadante/colônia 1/recombinante pET28a::cdk8 $\Delta$

3) Pellet/colônia $1 /$ recombinante pET28a::cdk8 $\Delta$

4) Sobrenadante/colônia 2/recombinante pET28a::cdk8 $\Delta$

5) Pellet/colônia $2 /$ recombinante pET28a::cdk8 $\Delta$

6) Sobrenadante/ grupo controle (sem o recombinante)

7) Pellet/ grupo controle (sem o recombinante) 
Foi realizado uma eletroforese bidimensional (2D) a fim de analisar a fração solúvel do lisado. Segundo dados do PROTPARAM, a CDK8 possui massa molecular de $41 \mathrm{kDa}$ sem a cauda de poli-histidina, com a cauda, a proteína teria em torno de $43 \mathrm{kDa}$, ficando um pouco abaixo da banda de $45 \mathrm{kDa}$ do marcador molecular (Protein Unstained Marker- Thermo Scientific), como observado nos géis SDS-PAGE 15\%. Este marcador também foi utilizado na segunda dimensão do gel 2D. A CDK8 apresenta pl de 8,7; sendo focalizada no gel em pH próximo ao seu ponto isoelétrico (Fig. 31).

O resultado do ensaio de western blot, utilizando um anticorpo primário que reconhece a cauda de histidina, correspondente a fração solúvel do lisado encontrase na Figura 32. Podemos observar uma banda em, aproximadamente, $45 \mathrm{kDa}$, o que confirma a presença da CDK8 $\Delta$-HisTag na fração solúvel.

Figura 31- Gel 2D da fração solúvel do lisado contendo a proteína CDK8 $\mathrm{O}$. marcador de massa molecular empregado foi o Unstained Protein Marker (Thermo Scientific).

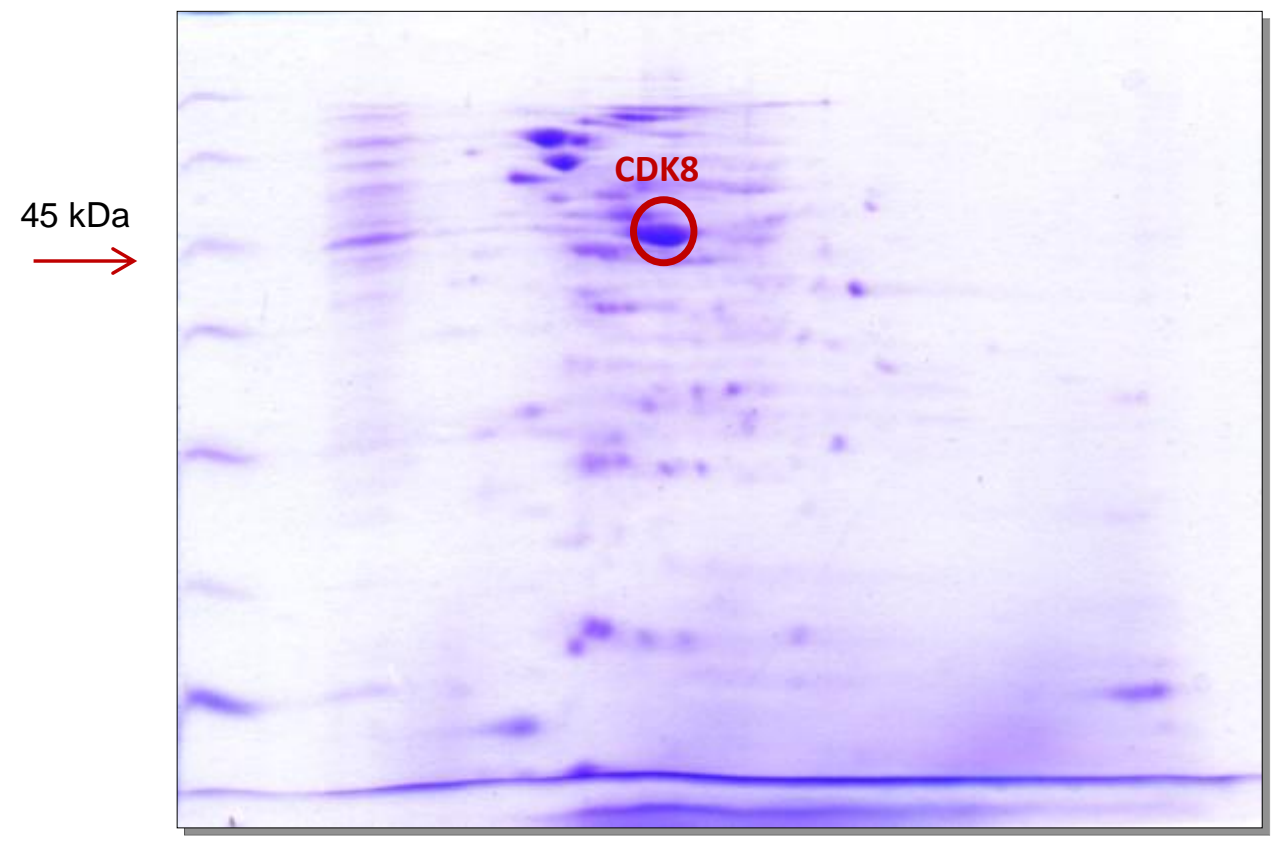

Fonte: autoria própria. 
Figura 32 - Resultado do ensaio de western blot para avaliar a expressão e solubilidade da CDK8 $\Delta$-HisTag na fração solúvel do lisado.

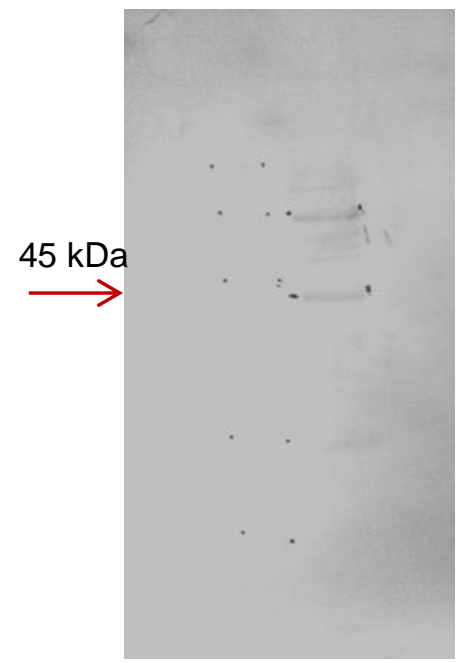

Fonte: autoria própria.

\subsection{Purificação da CDK8 $\Delta$-HisTag}

A purificação da proteína CDK8 $\Delta$-HisTag foi realizada empregando-se a cromatografia de afinidade em resina de níquel (especificar a coluna utilizada).

O aminoácido histidina possui o grupo imidazol, o qual tem afinidade pelo metal níquel devido à coordenação reversível formada pela doação de densidade eletrônica do nitrogênio para o íon metálico atuando, assim, como base de Lewis. Desta forma, a eluição da proteína de interesse pôde ser realizada utilizando-se um gradiente de imidazol, uma vez que este composto em alta concentração compete com a cauda de histidina, promovendo a eluição.

Inicialmente, foi utilizado o sobrenadante do lisado para separação em coluna de $\mathrm{Ni}^{2+}$, porém a CDK8 $\Delta$-HisTag não se ligou efetivamente à resina. Sendo assim, optou-se por avaliar como seria a ligação da proteína desnaturada à resina de afinidade ao $\mathrm{Ni}^{2+}$ (PAPARADIS, 2015). O sobrenadante assim obtido foi aplicado na coluna e o eluído pode ser observado no gel SDS PAGE 15\% da Figura 33. As frações eluídas com 50-250 mM de imidazol apresentaram-se bastante diluídas, porém demonstra que a proteína se ligou à resina. 
Figura 33 - SDS PAGE 15\% mostrando as frações eluidas da CDK8 $\Delta$-HisTag desnaturada, a partir da coluna de afinidade ao $\mathrm{Ni}^{2+}$.

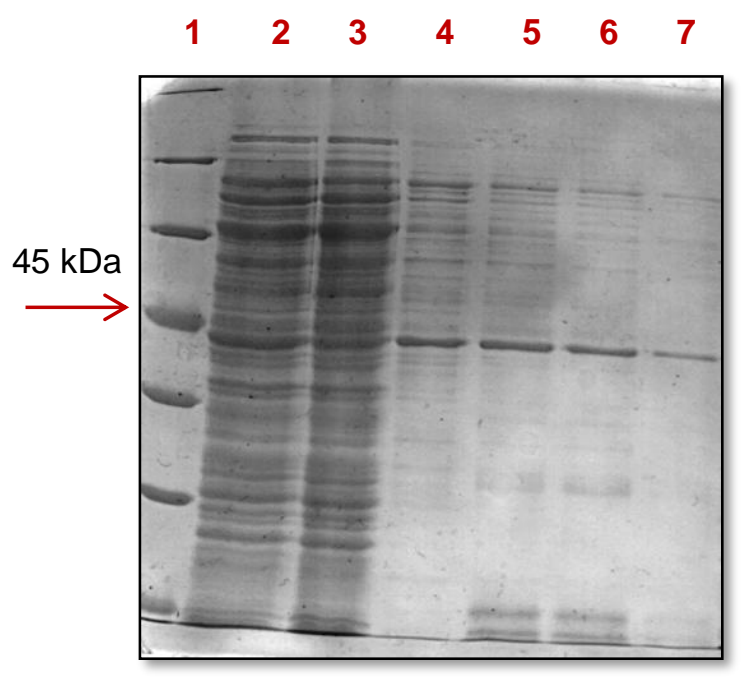

1) Marcador Unstained Protein Marker (Thermo Scientific)

2) Lavagem da amostra que não ligou na resina $-L 1$

3) Lavagem da amostra eu não ligou na resina $-\mathrm{L} 2$

4) Eluição com $50 \mathrm{mM}$ de imidazol

5) Eluição com 100 mM de imidazol

6) Eluição com $200 \mathrm{mM}$ de imidazol

7) Eluição com 250 mM de imidazol

Outra abordagem foi utilizada na tentativa de melhorar o rendimento na etapa cromatográfica. Foi realizada cromatografia de interação hidrofóbica para a obtenção da CDK8 $\Delta$-HisTag na forma solúvel (GENG; SHANG, 1992). Esta é uma técnica bastante utilizada para a separação de proteínas. O mecanismo de separação envolve interações hidrofóbicas entre os resíduos apolares da proteína e o grupo hidrofóbico exposto na resina. Na Figura 34, pode-se observar que a proteína começou a ser eluída com aproximadamente $10 \%$ do tampão de eluição, apresentando absorbância de aproximadamente $200 \mathrm{mAU}$, no entanto as frações coletadas dos picos referentes à eluição não puderam ser detectados por eletroforese em gel de poliacrilamida $15 \%$. 
Figura 34 - Perfil cromatográfico do sobrenadante (lisado) contendo a CDK8 $\Delta$-HisTag desnaturada, utilizando cromatografia de interação hidrofóbica.

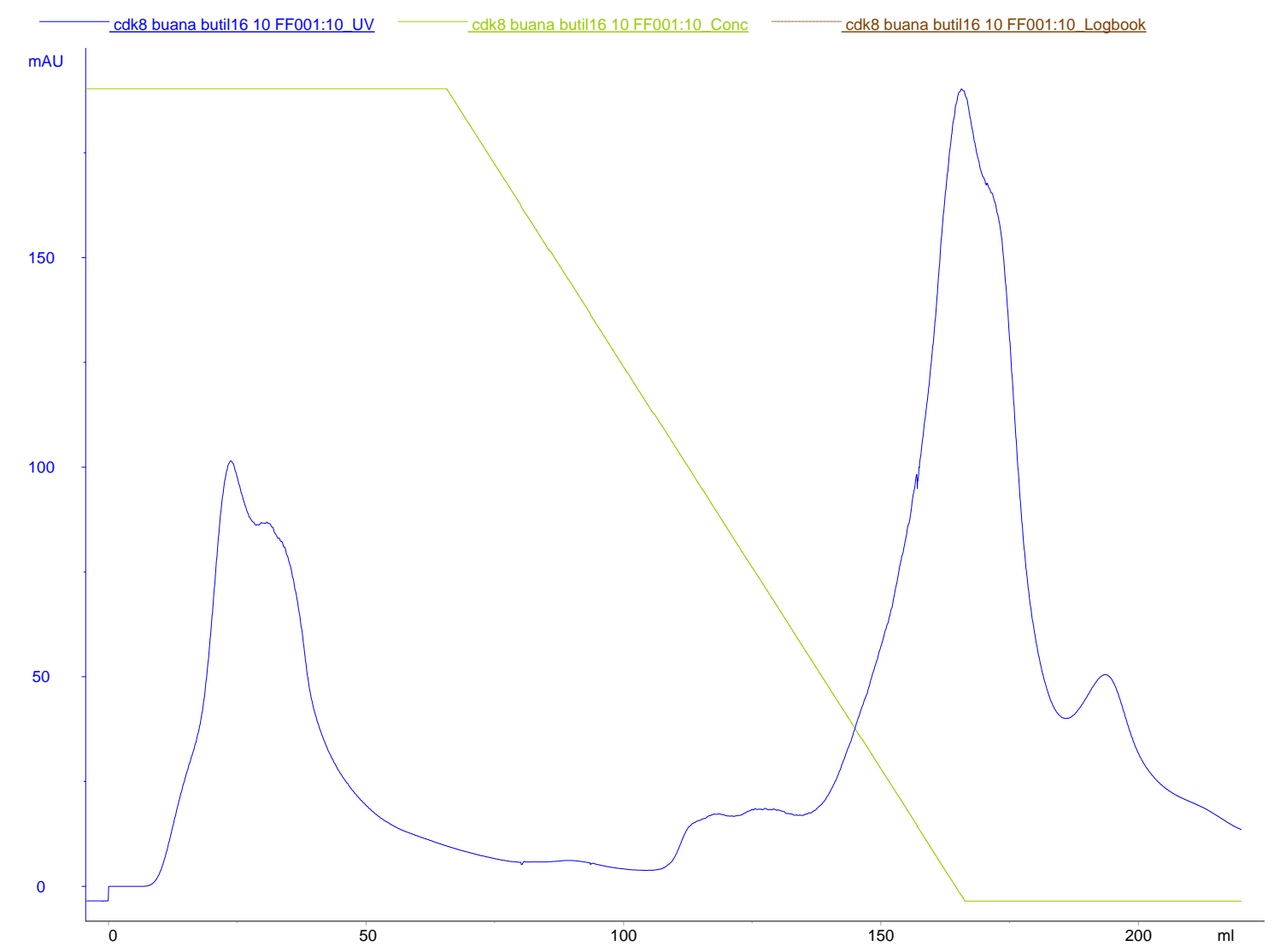

Fonte: Autoria própria.

Outra abordagem foi o uso do protocolo estabelecido por Upadhyay et al., (2016). O uso de TFE (trifluoroetanol) associado à ureia 3M promove a solubilização de corpos de inclusão e proporciona o reenovelamento da proteína humana em aproximadamente $85 \%$. Acredita-se que o TFE estabiliza a estrutura secundária e desestabiliza a estrutura terciária. O protocolo de solubilização com TFE foi realizado para a CDK8 8 -HisTag expressa em E. coli. Observou-se que este protocolo não foi eficiente para a solubilização dos corpos de inclusão, uma vez que a análise do sobrenadante obtido após a adição do tampão de reenovelamento não continha a proteína, mesmo quando concentrado, conforme mostrado no gel da Figura 35. 
Figura 35 - SDS PAGE 15\% mostrando o padrão das amostras obtidas utilizando o protocolo de solubilização e reenovelamento descrito por Upadhyay et al, (2016).

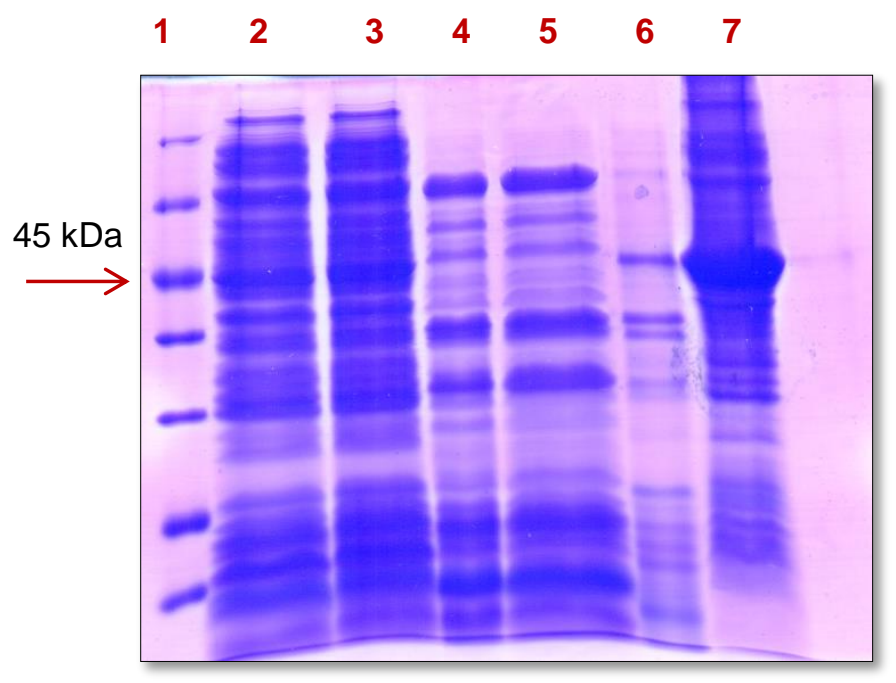

1) Marcador Protein Unstained Marker (Thermo Scientific)

2) Sobrenadante do lisado

3) Pellet do lisado

4) Sobrenadante contendo $50 \%$ TFE após centrifugação

5) Sobrenadante no tampão de reenovelamento

6) Sobrenadante concentrado

7) Pellet final, após centrifugação da amostra no tampão de reenovelamento

Fonte: Autoria própria.

Como observado até 0 momento, a CDK8 $\Delta$-HisTag encontra-se predominantemente no pellet, sendo mostrada essa predominância em todos os géis SDS-PAGE. Devido a alta concentração da amostra obtida no pellet do lisado, optou-se por insistir na sua solubilização utilizando condições desnaturantes, para posterior reenovelamento. Para tanto, foi utilizado o protocolo descrito por HE; OHNISHI, (2017). A proteína CDK84-HisTag foi então solubilizada seguindo este protocolo com algumas modificações, e submetida à purificação por cromatografia em coluna de $\mathrm{Ni}^{2+}$. Os cromatogramas relativos a esta purificação encontram-se nas Figuras 36 e 37. O pico correspondente à CDK8 4 -HisTag apresentou absorbância de aproximadamente $500 \mathrm{mAU}$ (Figuras 36 e 37), demonstrando sua interação à resina de $\mathrm{Ni}^{2+}$. As frações coletadas (frações $8-19$ ) renderam $7,69 \mathrm{mg} / \mathrm{mL}$ de proteína (Figura 38). 
Figura 36 - Perfil cromatográfico da fração contendo a CDK8 $\Delta$-HisTag, eluída a partir da coluna de afinidade ao $\mathrm{Ni}^{2+}$.

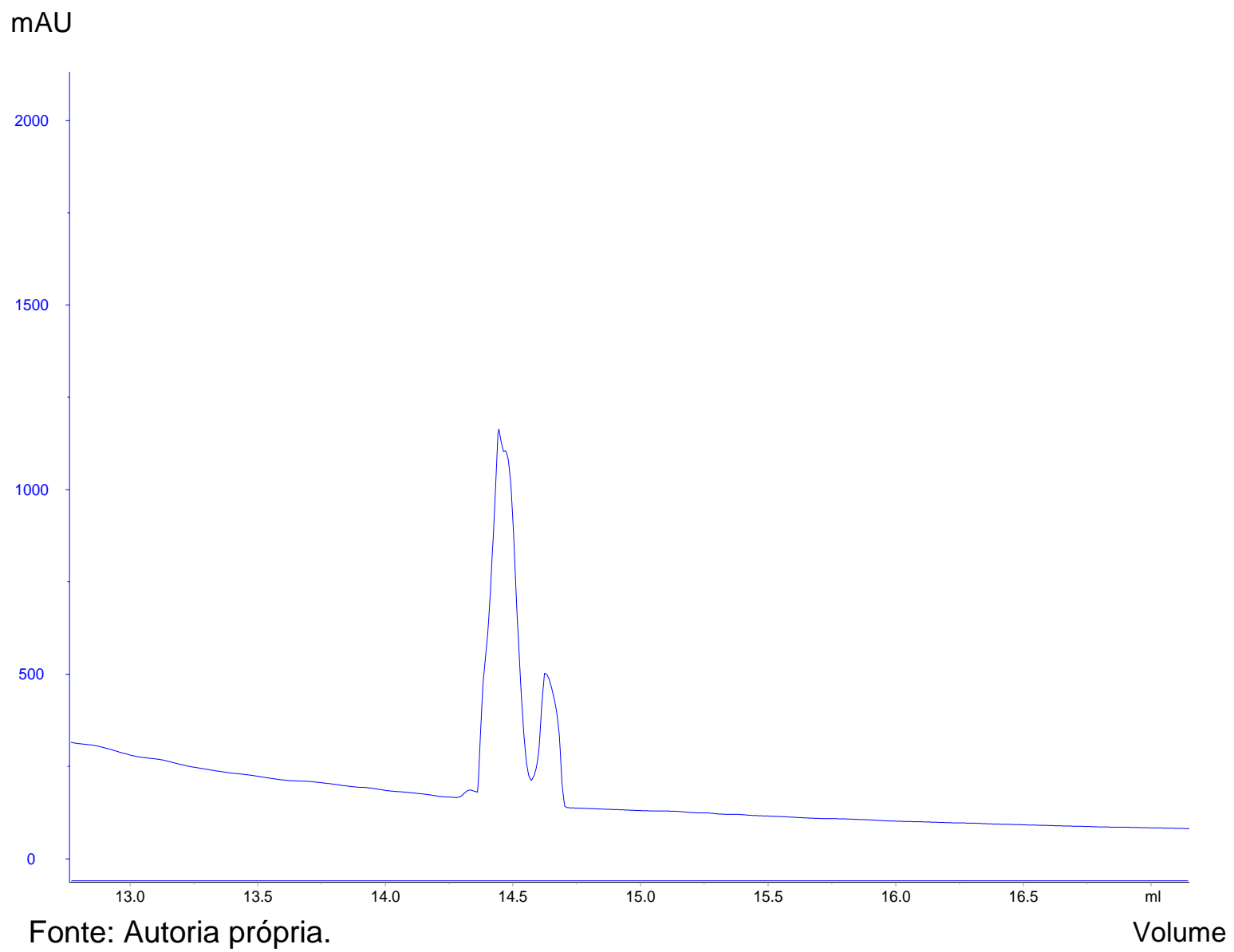


Figura 37 - Perfil cromatográfico da fração contendo a CDK8 $\Delta$-HisTag, eluída a partir da coluna de afinidade ao $\mathrm{Ni}^{2+}$ e a relação entre o percentual do tampão $\mathrm{B}$ (sem imidazol) versus quantidade de CV (volume de coluna).

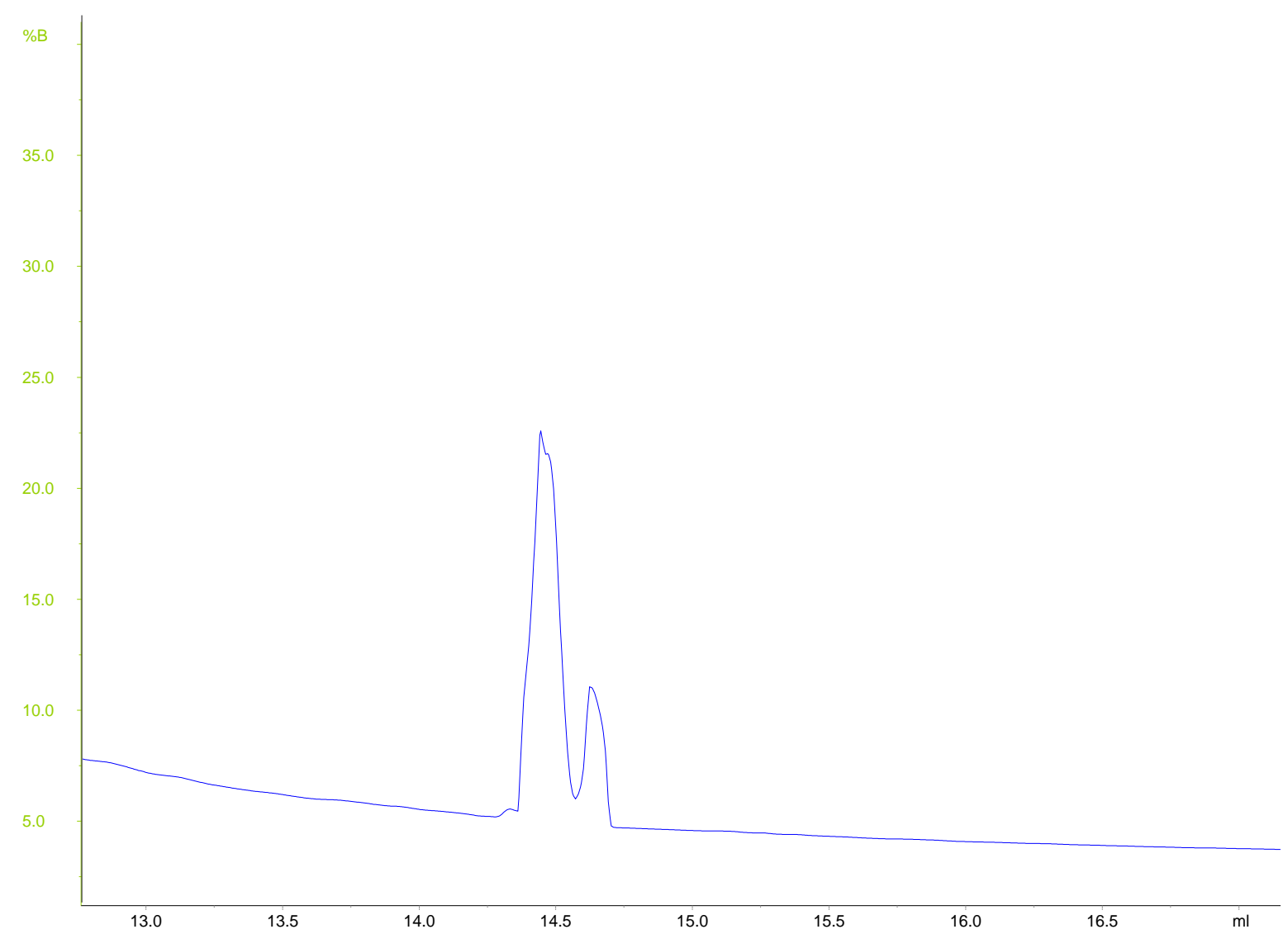

Fonte: Autoria própria. 
Figura 38 - SDS-PAGE 15\% mostrando as frações coletadas da CDK8 $\Delta$-HisTag a partir da coluna de afinidade ao $\mathrm{Ni}^{2+}$ utilizando um gradiente linear de $300 \mathrm{mM}$ de imidazol em tampão Hepes pH 7,5.
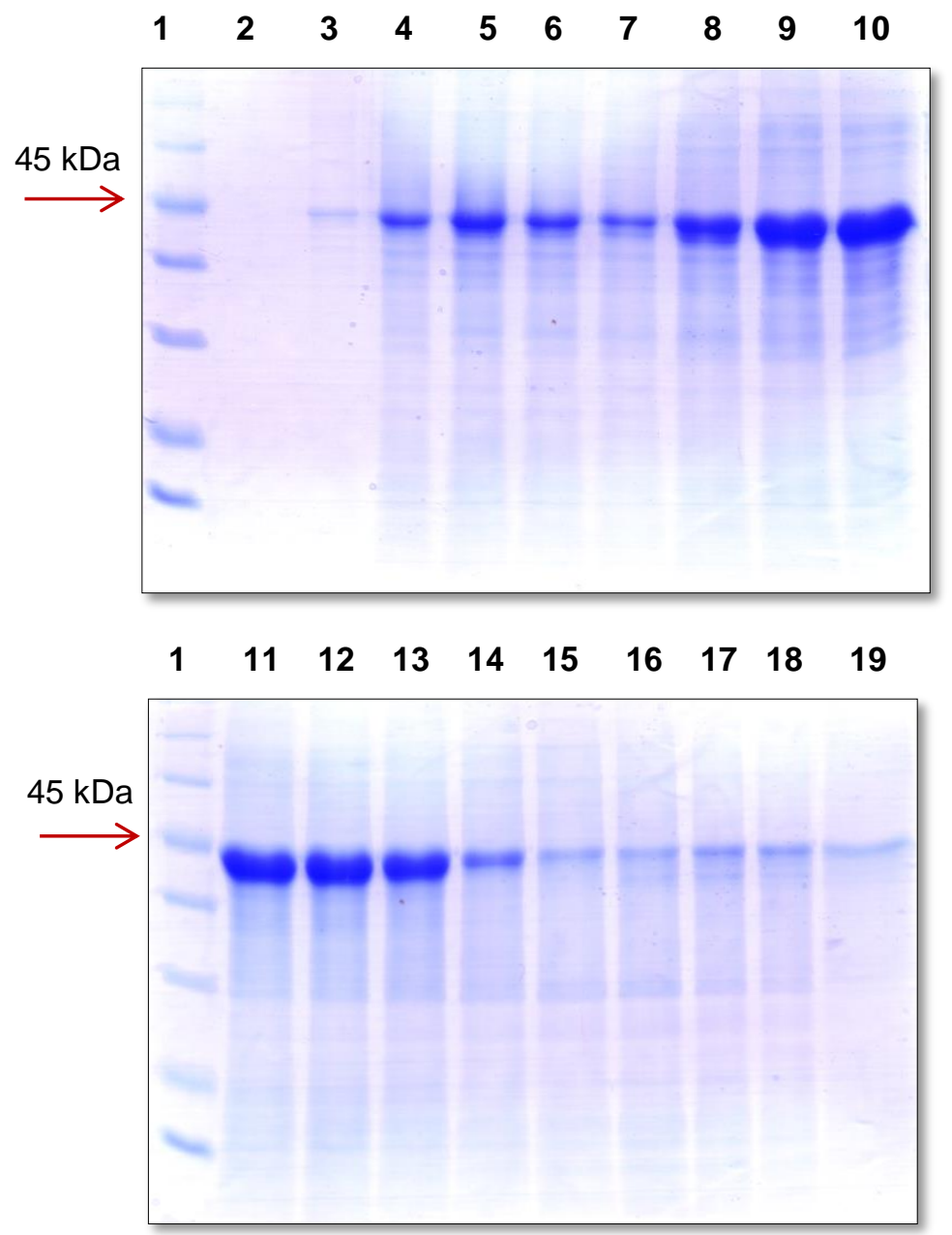

Fonte: Autoria própria.

Como pode ser observado a partir dos géis da figura 38, a utilização do protocolo descrito por HE; OHNISHI, (2017), com modificações, rendeu alta concentração da CDK8 $\Delta$, que pôde ser submetida a análises por dicroísmo circular e fluorimetria, com o objetivo de caracteriza-la estruturalmente. 


\section{Análise estrutural da proteína CDK84-HisTag por espectropolarimetria de dicroísmo circular e fluorescência}

As amostras das frações de 11 a 13 (Figura 38) foram analisadas por dicroísmo circular (Figura 39). O espectro obtido, após deconvolução e comparação com espectros de proteínas conhecidas, revelou que a CDK84-HisTag encontravase estruturada com $13,0 \%$ de hélices $\alpha ; 31,9 \%$ de folhas $\beta ; 35,4 \%$ de regiões randômicas e $20,1 \%$ de voltas $\beta$.

A análise da emissão de fluorescência da tirosina (Figura 40) mostrou um comprimento de onda máximo de emissão em torno de $360 \mathrm{~nm}$, mas este resultado é preliminar, indicando que outras análises devem ser feitas em condições desnaturantes a fim de fornecer mais informações acerca do comportamento da proteína, já que o comprimento de onda máximo de emissão é sensível ao ambiente no qual se encontram os resíduos de aminoácidos aromáticos, indicativo de mudanças na estrutura terciária da proteína.

Figura 39 - Espectro de dicroísmo circular da CDK8 $\Delta$-HisTag em tampão Hepes 50 mM, $\mathrm{NaCl} 150 \mathrm{mM}$.

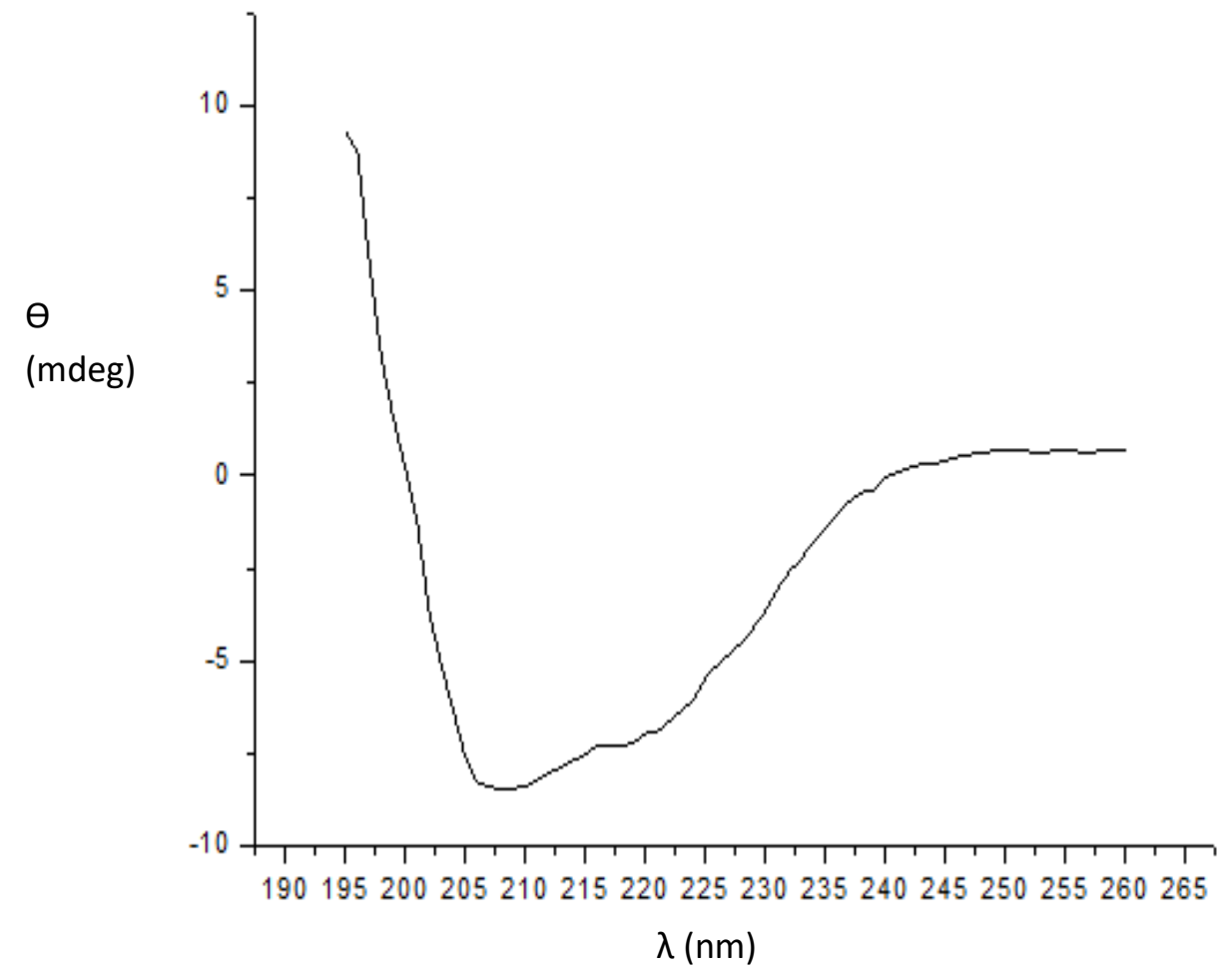

Fonte: Autoria propria. 
Figura 40 - Espectro de emissão de fluorescência da CDK8 $\Delta$-HisTag obtido em tampão Hepes $50 \mathrm{mM}$, NaCl $150 \mathrm{mM}$.

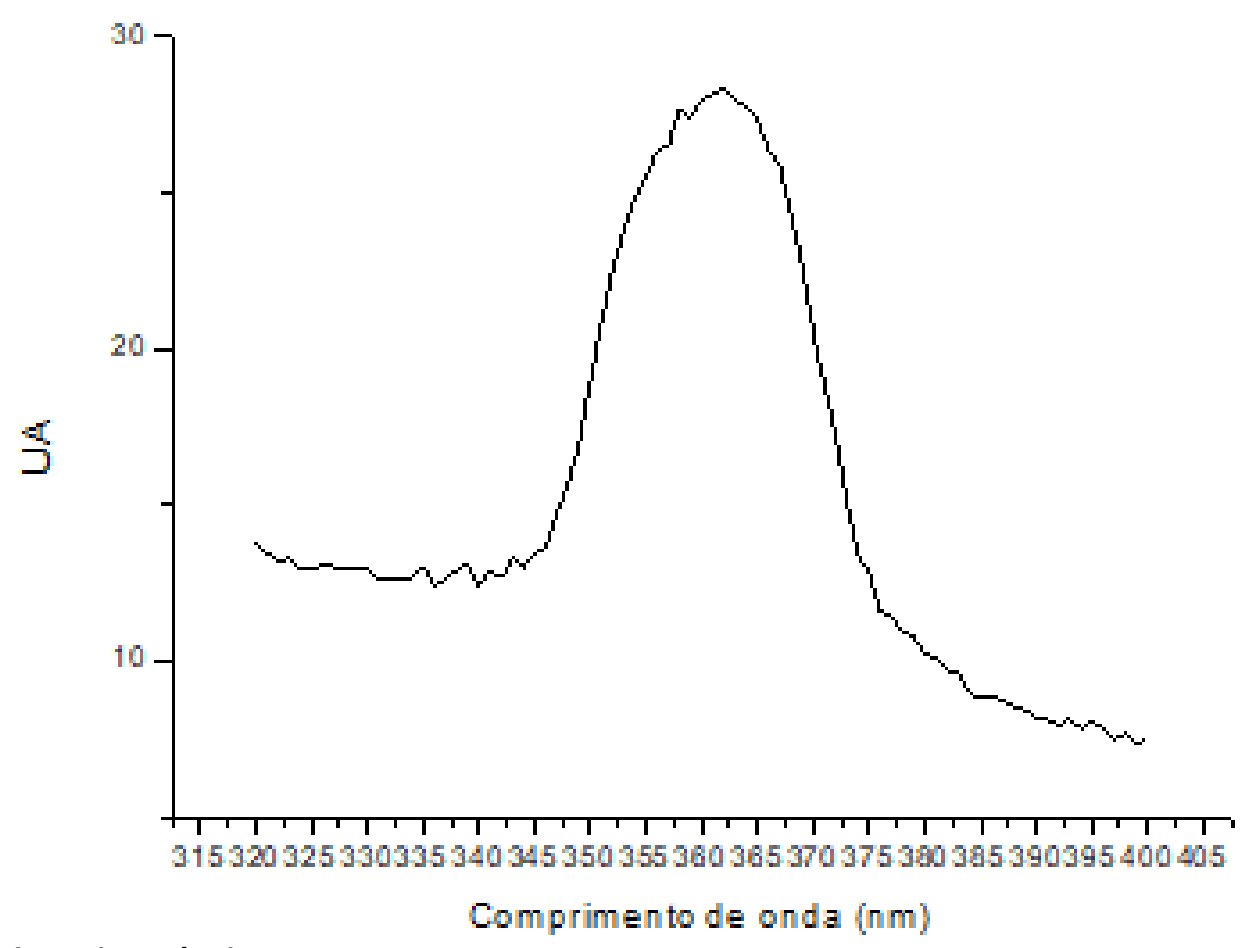

Fonte: Autoria própria.

Este é o primeiro relato da purificação da CDK8 8 -HisTag proveniente da expressão heteróloga em E. coli. Este estudo contribui para o conhecimento estrutural e funcional deste membro da família de CDKs, tão importantes por desempenhar papel na regulação do processo transcricional e no desenvolvimento de alguns tipos de câncer, dentre estes, o câncer de cólon.

A expressão de CDKs humanas em E. coli representa uma abordagem vantajosa uma vez que os custos operacionais são relativamente simples e reduzidos, fornecendo bons rendimentos de proteína, necessários para a realização de ensaios estruturais e funcionais. 


\section{CAPÍTULO 2}

Produtos Naturais 


\section{INTRODUÇÃO}

\subsection{Potenciais inibidores obtidos da espécie Waltheria brachypetala}

Waltheria brachypetala Turcz., espécie da qual os alcaloides foram isolados a fim de serem testados como inibidores da proteína CDK8, é um arbusto de pequeno porte, considerado como planta daninha de diversas culturas. Sua ocorrência é endêmica do semiárido nordestino. Popularmente conhecida como "guaxuma" e muitas vezes confundida como "malva" ou malva-branca (SABA; SANTOS, 2003). Pertence à família Malvaceae, sendo suas folhas utilizadas como antifúngico e o chá das raízes, para o tratamento de sintomas de perda de memória, cognição e atenção (KUBITZKI et. al., 2003), (LIMA, 2012).

Lima e colaboradores relataram a atividade anticolinesterase eritrocitária de alcaloides isolados das folhas de Waltheria brachypetala e verificaram uma atividade significante e ao nível do fármaco fisostigmina (LIMA et. al.; 2009).

Apesar do grande número de espécies de Waltheria, poucas foram estudadas sobre o ponto de vista químico. As principais classes de metabólitos secundários relatados por estes estudos são os alcaloides ciclopeptídicos, quinolônicos e ainda flavonoides.

Os alcaloides ciclopeptídicos são macrocíclos de 12, 13 ou 14 membros, formados a partir da ciclização de unidades de aminoácido via ligação peptídica ou de ciclização de unidades de aminoácido com uma unidade central de estirilamina (DEWICK, 2011). Na Figura 41, estão alguns alcaloides ciclopeptídicos isolados das raízes de $W$. brachypetala.

Os alcaloides quinolônicos são amplamente distribuídos entre microorganismos. Entre as plantas estes alcaloides possuem maior ocorrência em Rutaceae. A maioria desses alcaloides são alquil-quinolin-2-ona. Na Figura 42, estão alguns alcaloides quinolônicos isolados tanto das raízes quanto do caule de $W$. brachypetala (LIMA, 2012). 
Figura 41 - Alcaloides ciclopeptídicos isolados das raízes de W. brachypetala.

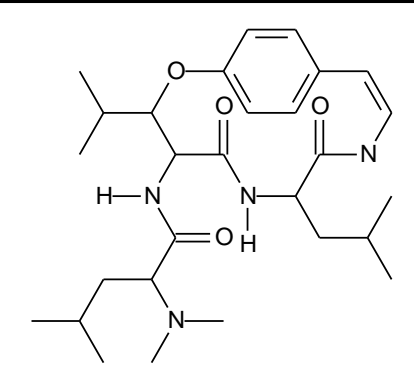

Franganina

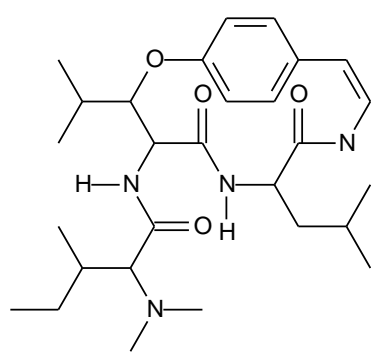

Frangulanina

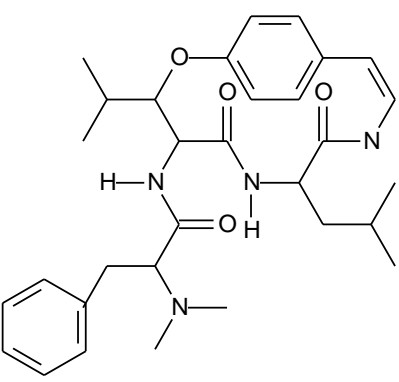

Adoutina $Y^{\prime}$

Fonte: Autoria própria.

Figura 42 - Alcaloides quinolônicos isolados das raízes e caule de W. brachypetala.

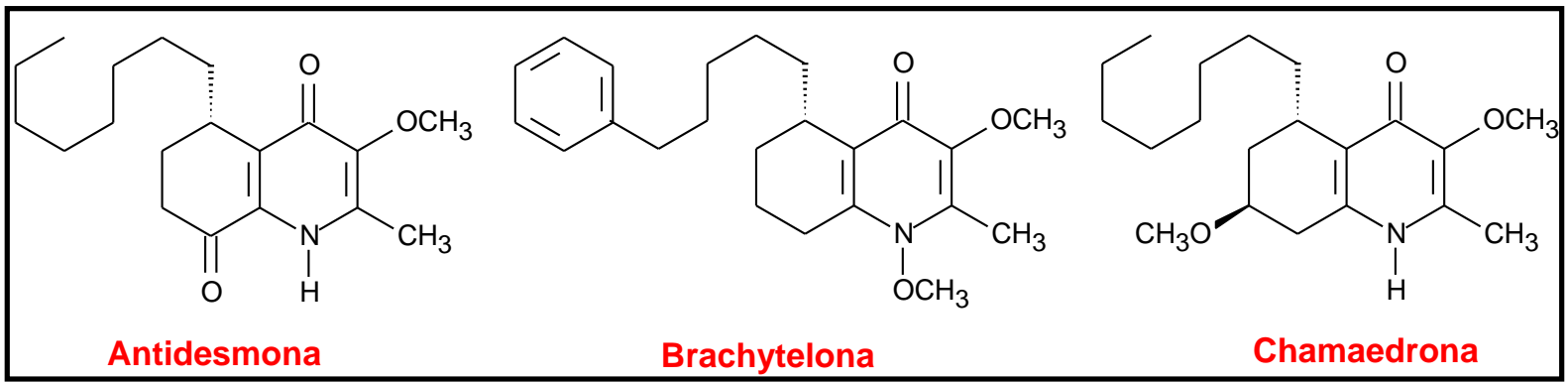

Fonte: Autoria própria. 


\section{OBJETIVOS}

\subsection{Objetivo Geral}

Isolamento e identificação de metabólitos secundários das folhas de Waltheria brachypeta.

\subsection{Objetivos específicos}

- Preparar os extratos das folhas de W. brachypetala;

- Realizar cromatografia em coluna da fração AcOEt, hexânica e subfrações obtidas.

- Realizar CCD das frações obtidas nos fracionamentos em coluna de sílica e em HPLC

- Realizar análises por LC-MS das frações promissoras

- Identificar e caracterizar os metabólitos secundários por RMN (Ressonância Magnética Nuclear de ${ }^{1} \mathrm{H}$ e ${ }^{13} \mathrm{C}$ ) 


\section{MATERIAIS E MÉTODOS}

\subsection{Coleta e identificação do material vegetal}

As folhas de Waltheria brachypetala foram coletadas no campus da Universidade Estadual de Feira de Santana (UEFS), em novembro do ano de 2009, sendo identificada pelo botânico Msc. Cosme Correia dos Santos, sob supervisão do Prof. Dr. Luciano Paganucci de Queiroz. A voucher da espécie encontra-se depositada no herbário da UEFS sob o código HUEFS 148549.

\subsection{Preparo dos extratos e isolamento dos metabólitos}

Após serem coletadas, as folhas de $W$. brachypetala foram lavadas com água para a retirada de material residual e submetidas à secagem em estufa a $40^{\circ} \mathrm{C}$, sob ventilação por um período de sete dias. Em seguida, foram moídas em moinho de facas, sendo obtidos $678 \mathrm{~g}$.

Para a extração e isolamento dos metabólitos secundários foram utilizadas técnicas cromatográficas como cromatografia em coluna de gel de sílica (70 - 230 mesh, Across Organic) à pressão atmosférica e Cromatografia Líquida de Alta Eficiência.

Para o preparo dos extratos, as folhas moídas foram submetidas à maceração com etanol por seis vezes com intervalo de 72 horas. A cada intervalo de 72 horas, o líquido extraído foi filtrado e posteriormente concentrado sob pressão reduzida em rota-evaporador (R-200 equipado com banho Buchi B-490 e refrigerador Neslab) a $40{ }^{\circ} \mathrm{C}$ para obtenção do extrato etanólico das folhas (WFE). Após ser solubilizado em água/metanol (3:1), o extrato WFE foi submetido à partição líquido-líquido (Esquema 1) com hexano e acetato de etila.

As fases WFH e WFA obtidas do extrato etanólico das raízes foram submetidas à análise por CCDA, no intuito de identificar, qualitativamente a presença de alcaloides. As cromatoplacas foram eluídas com hexano/AcOEt (95:5 e 8:2) e DCM/MeOH (98:2 e 96:4). As cromatoplacas foram analisadas por luz UV nos comprimentos de onda de 254 e $365 \mathrm{~nm}$, reveladas com vanilina-ácido sulfúrico com aquecimento da placa e o reagente de Dragendorff. 
O fracionamento em CC de gel de sílica de WFA (fração AcOEt das folhas de W. brachypetala) resultou em 114 frações, das quais as frações WFA-64, WFA-73, WFA-88, WFA-94 e WFA-96 foram submetidas à extração em fase sólida (SPE), utilizando um cartucho com fase estacionária de C-18 (Cromabond), a fim de eliminar possíveis interferentes nas análises por LC-MS.

A fração WFA-94, obtida do fracionamento em coluna de sílica da fração WFA foi submetida a $\mathrm{CC}$ de sílica gel (2x) utilizando $\mathrm{DCM} / \mathrm{MeOH}$ em ordem crescente de polaridade, fornecendo a fração WFA-94-15-20, eluída em DCM/MeOH (97:3) fornecendo o alcaloide brachytelona.

A fase hexânica das folhas $(7,5 \mathrm{~g})$ de Waltheria brachypetala foi submetida à cromatografia em coluna de sílica (70 -230 mesh, Across Organic), utilizando como fase móvel hexano e hexano-AcOEt em ordem crescente de polaridade. As frações foram separadas de acordo com as diferentes cores observadas a olho nu, sendo obtidas 170 frações. Estas foram monitoradas por CCD, sendo posteriormente reunidas com base na semelhança de Rfs entre os spots. Foram obtidas assim 18 sub-frações. A subfração WFH-25 foi submetida a CC de sílica utilizando $\mathrm{DCM} / \mathrm{MeOH}$ em ordem crescente de polaridade, fornecendo a fração WFH-25-3, eluída com $\mathrm{DCM} / \mathrm{MeOH}$ (95:5) eidentificada como uma mistura dos esteroides sitosterol e estigmasterol.

A subração WFH-30 foi obtida do fracionamento de WFH em coluna de sílica e eluída com DCM 100\%, fornecendo o flavonoide tetrametoxilado 5, 7, 3', 4'tetrametoxicatequina.

A subfração WFH-34 foi submetida a CC de sílica gel (2x) utilizando $\mathrm{DCM} / \mathrm{MeOH}$ em ordem crescente de polaridade, a subfração WFH-34-15-17 foi eluída em $\mathrm{DCM} / \mathrm{MeOH}$ (98:2), fornecendo a mistura de triterpenoides betulina e eritrodiol.

As frações WFA-94-15-20, WFH-25-3, WFH-30 e WFH-34-15-17 foram submetidas à análise por $\mathrm{RMN}$ de ${ }^{1} \mathrm{H}$ e ${ }^{13} \mathrm{C}$ e comparação com dados da literatura. 


\subsection{Métodos de determinação estrutural}

\subsubsection{Espectrometria de Ressonância Magnética Nuclear de ${ }^{1} \mathrm{He}{ }^{13} \mathrm{C}$}

Para as análises de RMN, as amostras foram solubilizadas em solventes deuterados da Aldrich Chemical Company e Acros Organics com percentual de deutério de 99,8\% para $\mathrm{CDCl}_{3}$ e $\mathrm{MeOD}$.

Foi utilizado o espectrômetro de RMN Bruker DRX 9,8 T (400 MHz para RMN de ${ }^{1} \mathrm{H}$ e $100 \mathrm{MHz}$ para $\mathrm{RMN}{ }^{13} \mathrm{C}$ ) do Departamento de Química da Universidade Federal de São Carlos-Ufscar.

\subsubsection{Análise por Cromatografia Líquida acoplada a Espectrometria de Massas (LC-MS)}

Para as análises por LC-MS foi utilizado o equipamento Applied Bio System MS (triplo quadrupolo) equipado com fonte ESI (Electrospray ionization), de ionização por eletrospray. A separação cromatográfica foi feita no HPLC 1200 da Agilent, utilizando gradiente exploratório de $\mathrm{ACN}-\mathrm{MeOH}$, volume de injeção de 10 $\mu \mathrm{L}$, fluxo de $0,8 \mathrm{~mL} / \mathrm{min}$ e detector UV- $260 \mathrm{~nm}$. 
Esquema 1 - Fluxograma de partição do extrato etanólico das folhas de $W$. brachypetala (WFE)

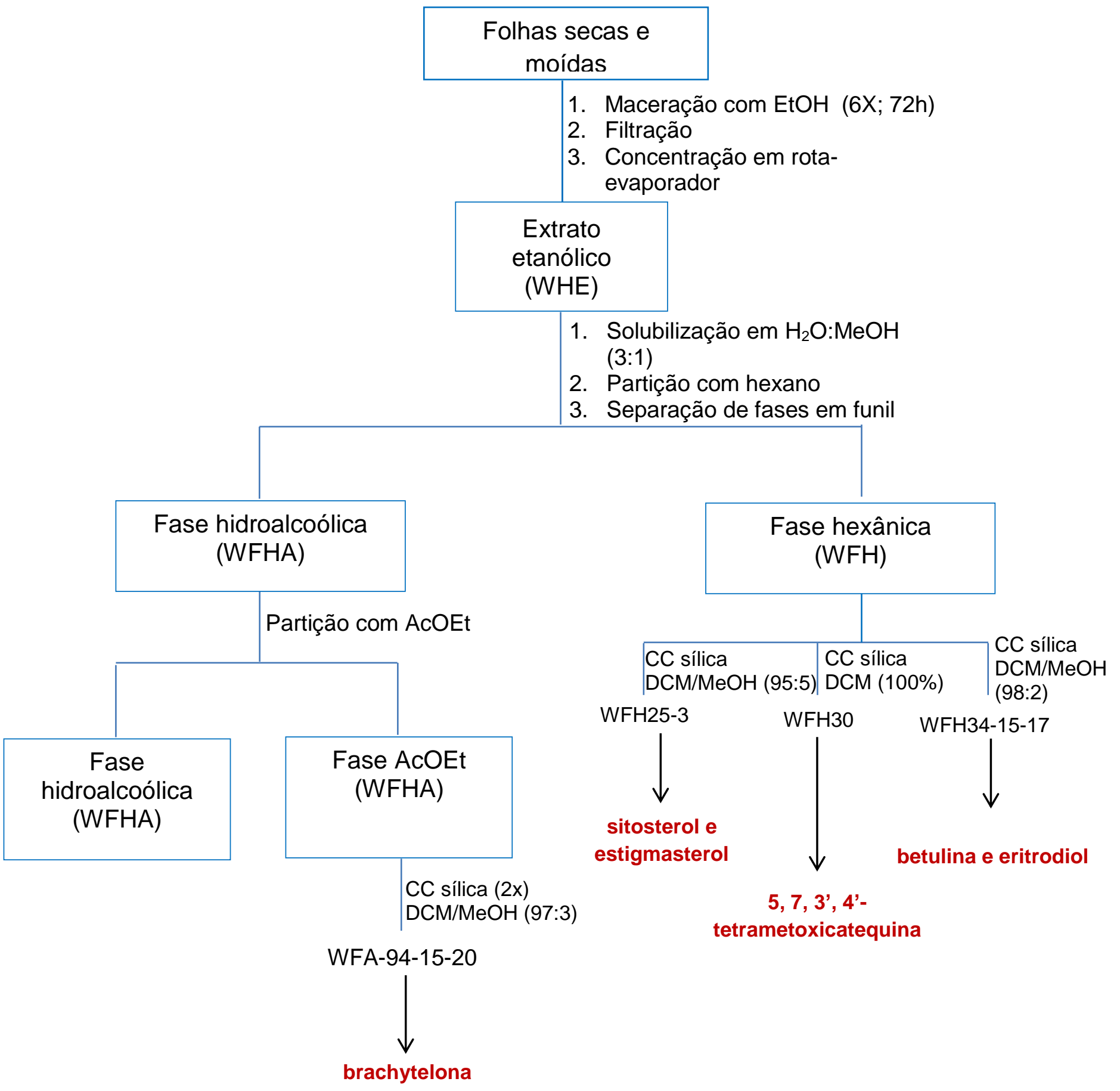

Fonte: Autoria própria 


\section{RESULTADOS E DISCUSSÃO}

\subsection{Identificação e isolamento de metabólitos de Waltheria brachypetala}

As frações WFA, WFA-73 e WFA-94, quando analisadas por LC-MS, no experimento de MRM (Multiple Reaction Monitoring), no qual os analisadores de massas Q1 e Q3, selecionam os íons precursor e produto, respectivamente, definindo uma transição de $\mathrm{m} / \mathrm{z}$ específica, resultaram na identificação de 2 alcaloides (Fig. 43). Na fração WFA foi identificado majoritariamente o alcaloide walteriona $A$, assim como na fração WF-73. Na fração WFA-94, foi identificado o alcaloide brachytelona e walteriona A. As transições $\mathrm{m} / \mathrm{z}$ dos alcaloides identificados estão mostradas nos espectros de massas da Fig. 43.

Figura 43 - Espectro de Massas (A - D) de frações da fase AcOE obtida das folhas de W. brachypetala (experimento de MRM/ LC-MS).

\section{(A) WFA}

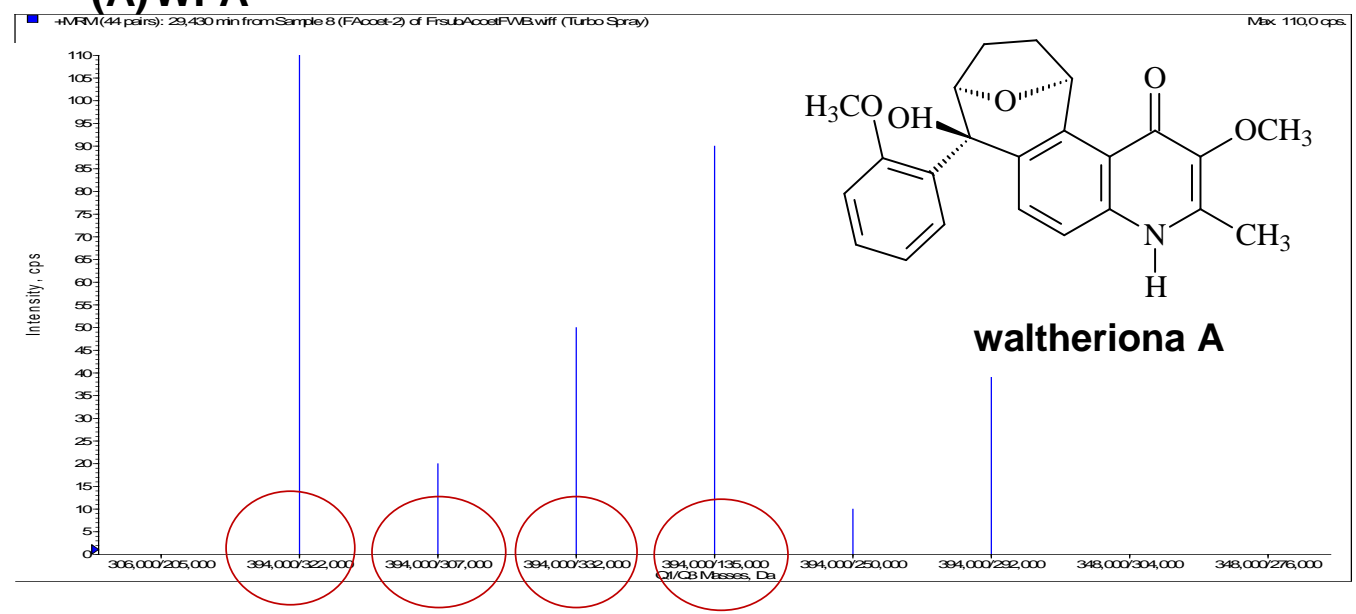

(B) WFA-73

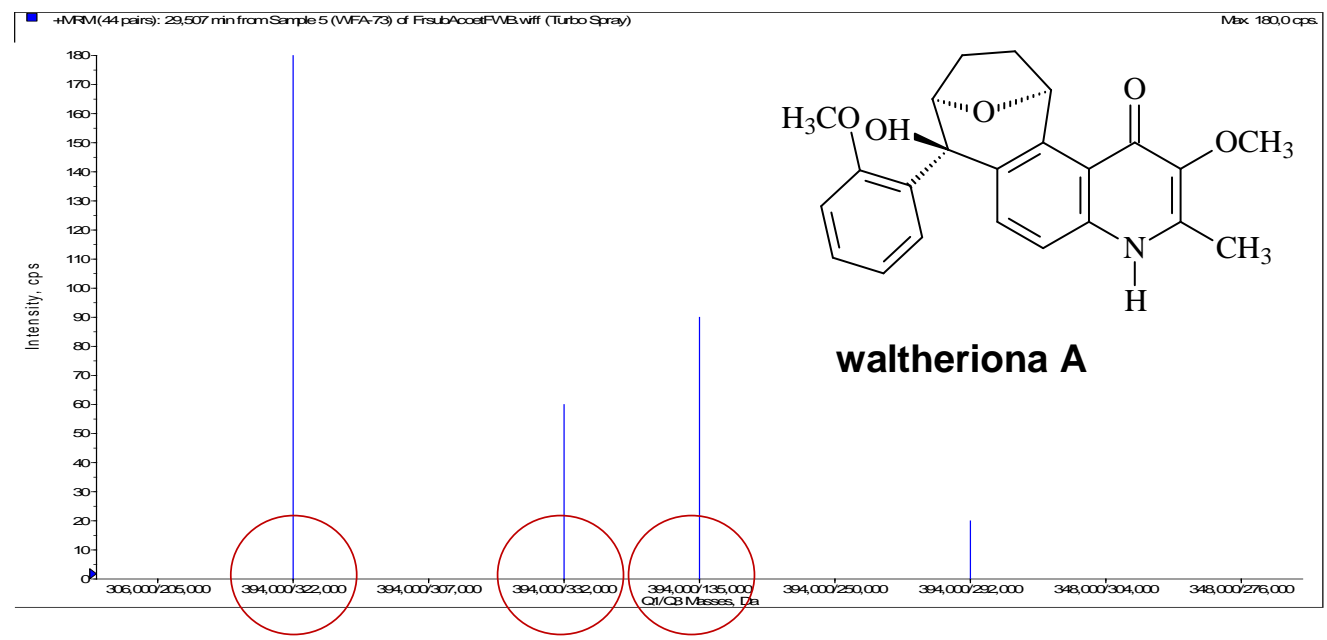


(C) WFA-94

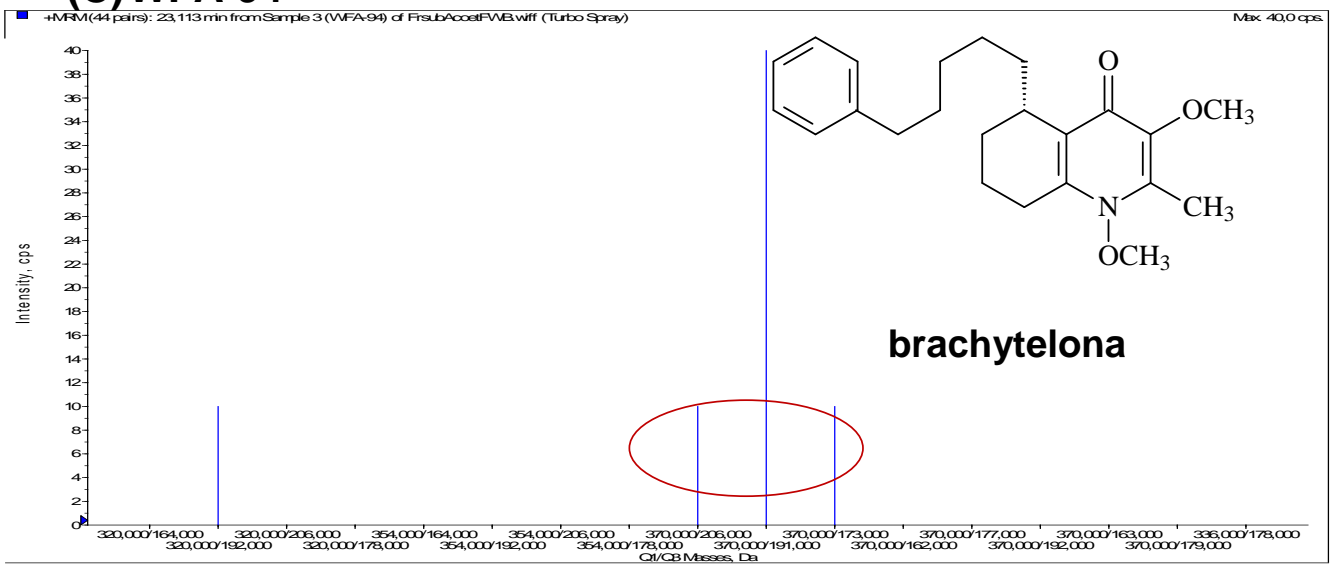

(D) WFA-94

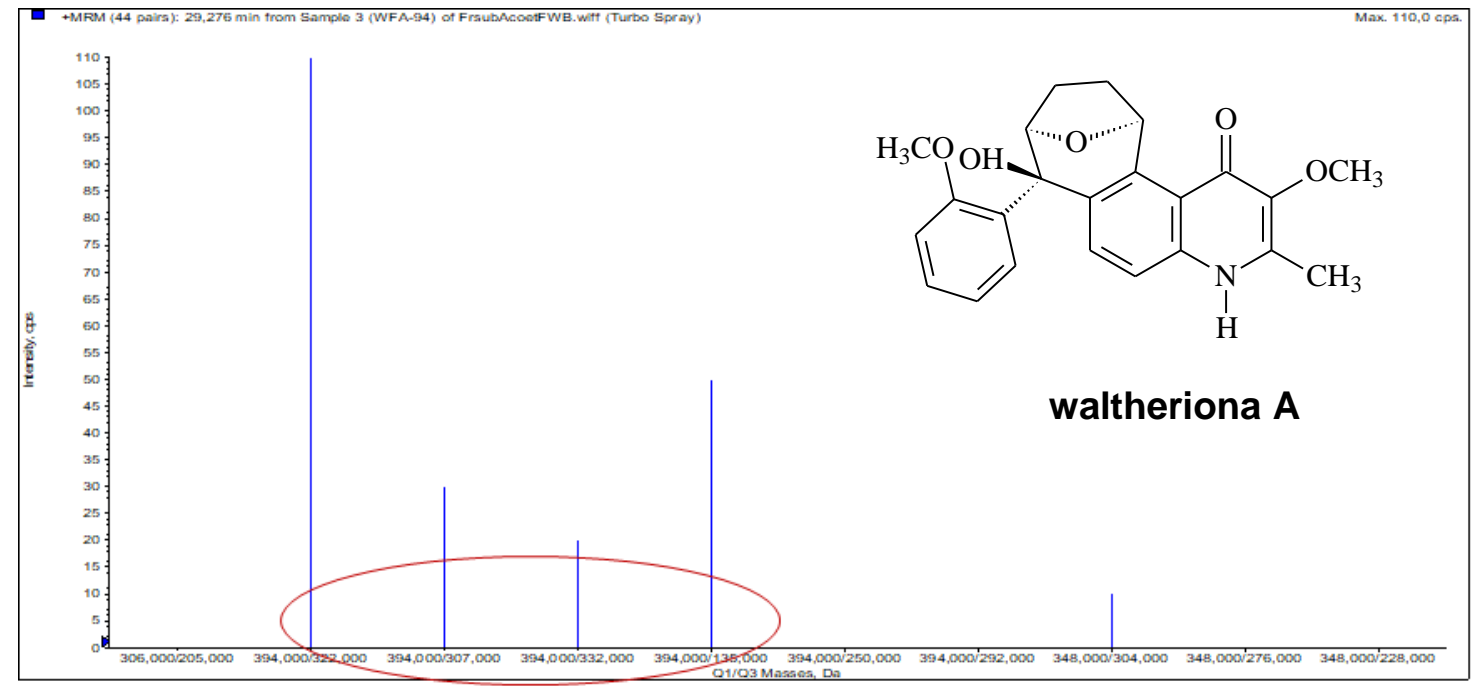

Fonte: Autoria própria.

\subsubsection{Identificação do alcaloide brachytelona por análise de $R M N^{1} \mathrm{He}^{13} \mathrm{C}$}

O alcaloide identificado na amostra WFA-94-15-20, apresentou-se como um líquido alaranjado, revelando postitivamente com o reagente de Dragendorff. O espectro de $\mathrm{RMN}{ }^{13} \mathrm{C}$ (Fig. 44) da fração WFA-94-15-20 mostrou um sinal em $\delta$ 62,10 referente à presença da metoxila em $\mathrm{C}-3$, em $\delta$ 66,6 um sinal atribuído à metoxila ligada a nitrogênio e 4 sinais referentes aos carbonos olefínicos C-2, C-3, C-9 e C-10 entre $\delta 128$ e 145. A comparação com dados da literatura e dados previamente publicados na tese de doutorado de Lima (2012); sugeriu tratar-se do alcaloide aril-alquil-quinolin-4-ona, identificado como brachytelona (BUSKE et al., 1999). 
Figura 44 - Espectro de RMN de ${ }^{13} \mathrm{C}$ da fração WFA-94-15-20 ( $\left.\mathrm{CDCl}_{3}, 100 \mathrm{MHz}\right)$.

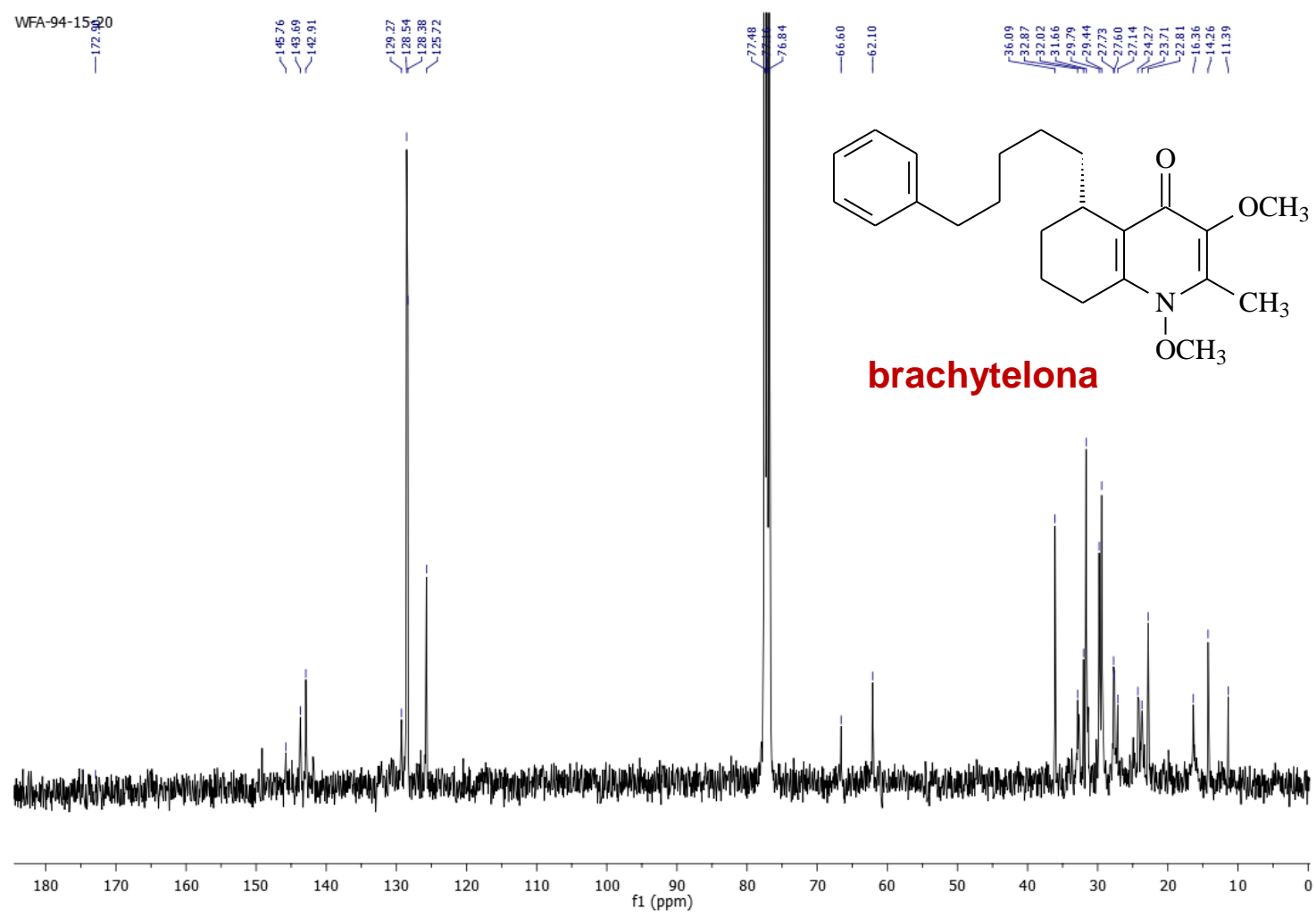

Fonte: Autoria própria.

\subsubsection{Identificação da mistura de triterpenos composta por betulina e eritrodiol}

A mistura identificada na fração WFH-34-15-17 apresentou um spot de cor roxa em CCD, utilizando vanilina como revelador, o que é característico de substâncias de origem terpênica. A fração WFH-34-15-17 mostrou no espectro de RMN de ${ }^{13} \mathrm{C}$ (Fig. 45) entre $\delta 14,8$ e 28,23 a presença de sinais referentes aos carbonos metílicos característicos de triterpenos. Em $\delta 79,2$, um sinal referente ao carbono carbinólico de triterpenos $3 \beta-\mathrm{OH}$. Em $\delta 109,9$ e $\delta 150,1$ sinais referentes aos carbonos da ligação dupla em C-20 e C-29 da betulina. Em $\delta$ 60,7 um sinal referente ao carbono oximetilênico C-28 característico da betulina e em $\delta$ 69,9, um sinal referente ao carbono oximetilênico do eritrodiol. A comparação com dados da literatura permitiu identicar a mistura composta pelos triterpenos betulina e eritrodiol (MAHATO; KUNDU, 1994). 
Figura 45 - Espectro de RMN ${ }^{13} \mathrm{C}$ da fração WFH34-15-17 ( $\left.\mathrm{CDCl}_{3}, 100 \mathrm{MHz}\right)$.

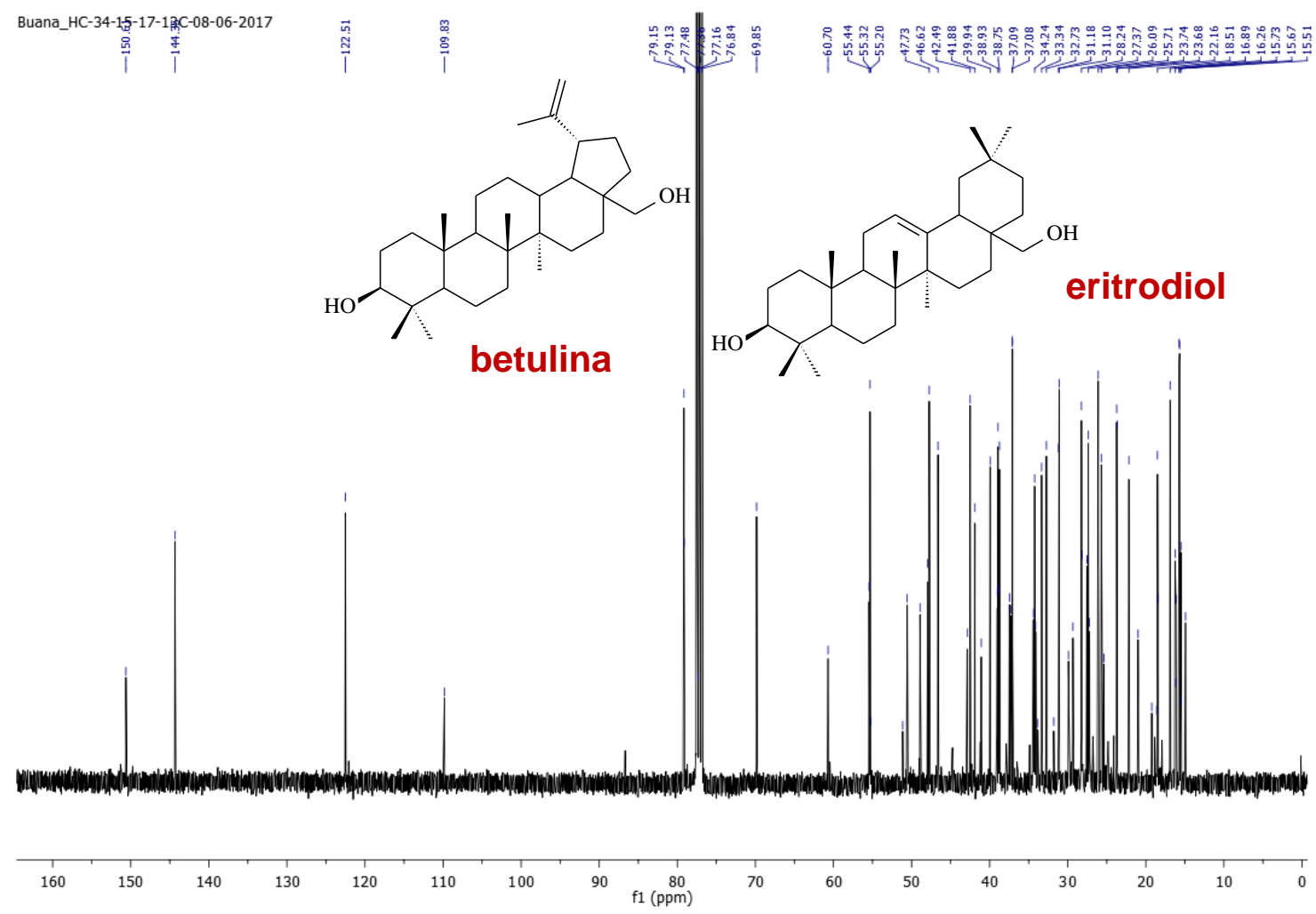

Fonte: Autoria própria.

\subsubsection{Identificação do flavonoide 5, 7, 3', 4'-tetrametoxicatequina}

A substância presente na fração WFH-30 apresentou um spot de cor laranja em CCD, utilizando a vanilina como revelador. O espectro de RMN de ${ }^{1} \mathrm{H}$ (Fig. 46) da fração WFH-30 mostrou 4 simpletos entre 3,57 e 3,70 referentes aos hidrogênios oximetílicos do anel A e C, sugerindo a presença da catequina tetrametoxilada. $\mathrm{O}$ espectro mostrou ainda um dupleto em 4,53 $(J=8 \mathrm{~Hz})$ referente à $\mathrm{H}-2$, dois duplos dupletos em 2,54 ( $\mathrm{J}=8$ e $16 \mathrm{~Hz}$; H-4ax) e 2,81 ( $\mathrm{J}=8$ e $\left.16 \mathrm{~Hz}, \mathrm{H}-4_{\text {eq }}\right)$ referentes à $\mathrm{H}$ 4, um multipleto em 3,97 característico de H-3. A comparação com dados publicados por Lima (2012) permitiu identificar o flavonoide 5, 7, 3', 4'-tetrametoxicatequina. 
Figura 46 - Espectro de RMN ${ }^{1} \mathrm{H}$ da fração WFH-30 (MeOD, 400 MHz).

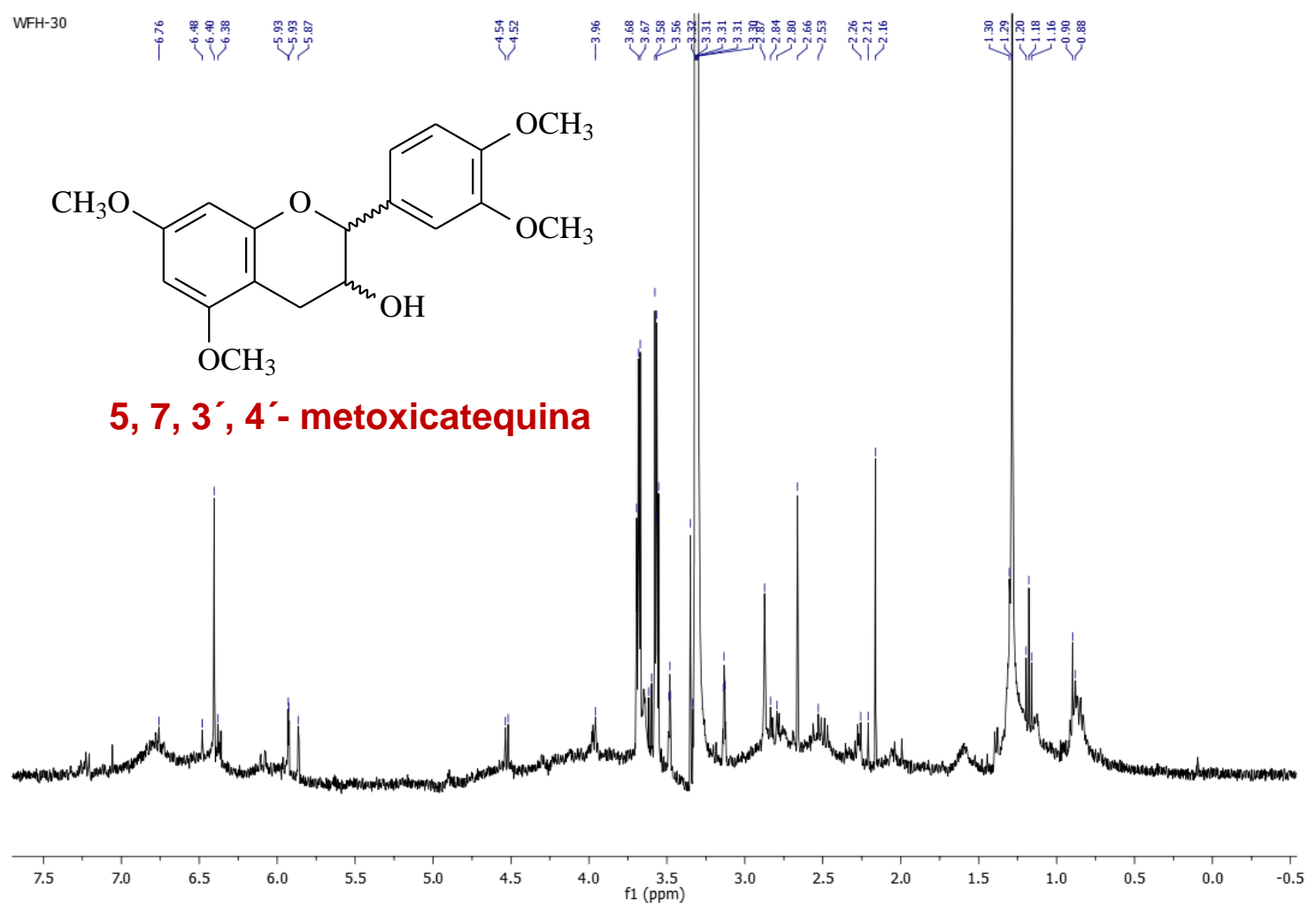

Fonte: Autoria própria.

\subsubsection{Identificação da mistura composta por sitosterol e estigmasterol}

O espectro de RMN de ${ }^{1} \mathrm{H}$ (Fig. 47) da fração WFH-34-15-17 mostrou um multipleto em $\delta 3,51$ referente ao hidrogênio $\mathrm{H}-3$ em ligação $3 \beta-\mathrm{OH}$ de esteróis, um dupleto largo em $\delta 5,34$ referente a $\mathrm{H}-6$, dois duplos dupletos em $\delta 5,02$ e $\delta 5,15$ referentes aos hidrogênios olefínicos $\mathrm{H}-22$ e H-23 do estigmasterol. O espectro de RMN ${ }^{13} \mathrm{C}$ (Fig. 48) mostrou um sinal em $\delta 72,2$ característico do carbono carbinólico C-3, sinais em $\delta 122$ (C-6), $\delta 141$ (C-5), $\delta$ 129,6 (C-23) e $\delta 138$ (C-22), referentes aos carbonos da ligação dupla. A comparação com dados da literatura permitiram identificar a mistura sitosterol e estigmasterol. 
Figura 47 - Espectro de RMN ${ }^{1} \mathrm{H}$ da fração WFH-34-15-17 $\left(\mathrm{CDCl}_{3}, 400 \mathrm{MHz}\right)$.

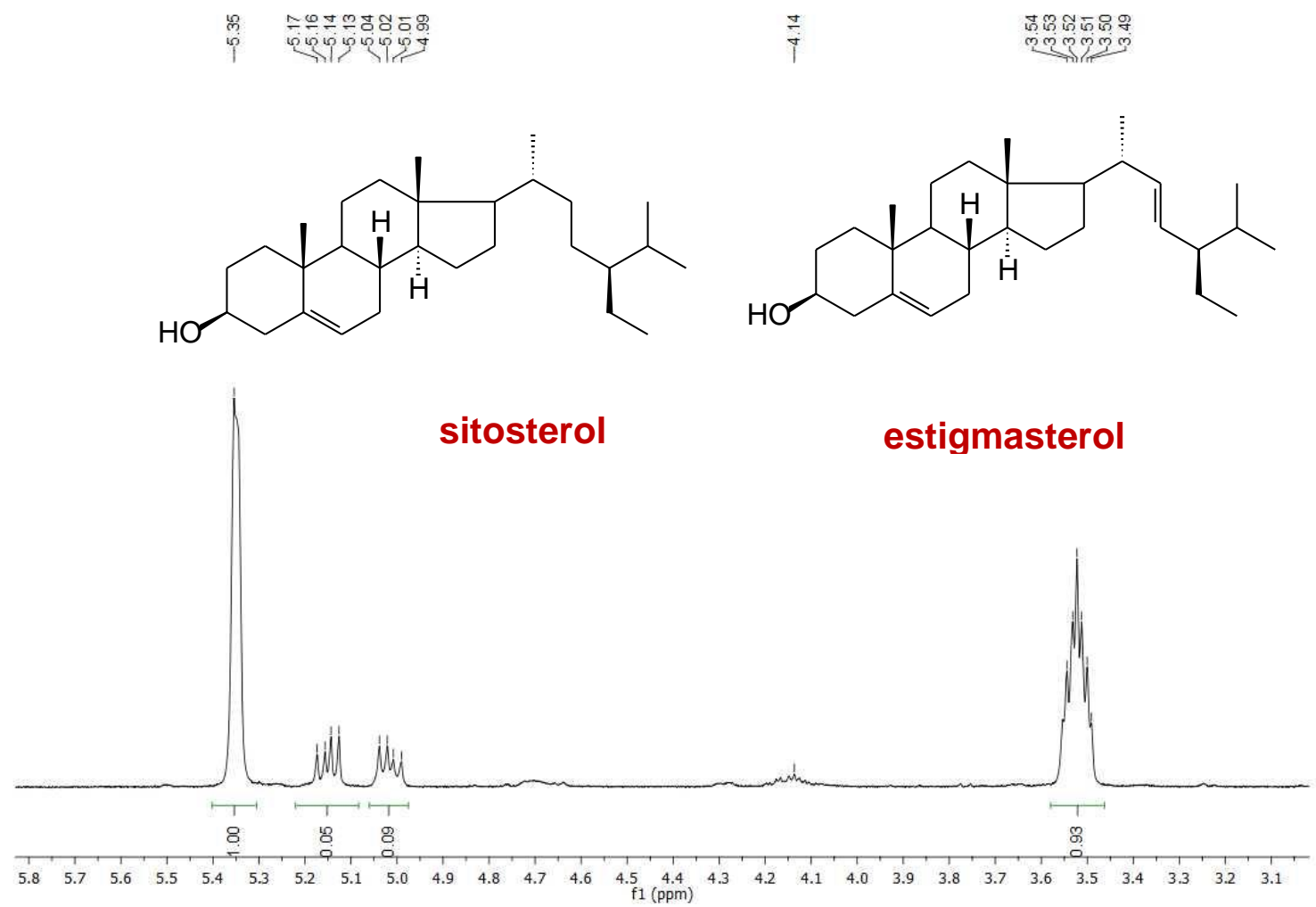

Fonte: Autoria própria.

Figura 48 - Espectro de RMN ${ }^{13} \mathrm{C}$ da fração WFH-34-15-17 $\left(\mathrm{CDCl}_{3}, 100 \mathrm{MHz}\right)$.

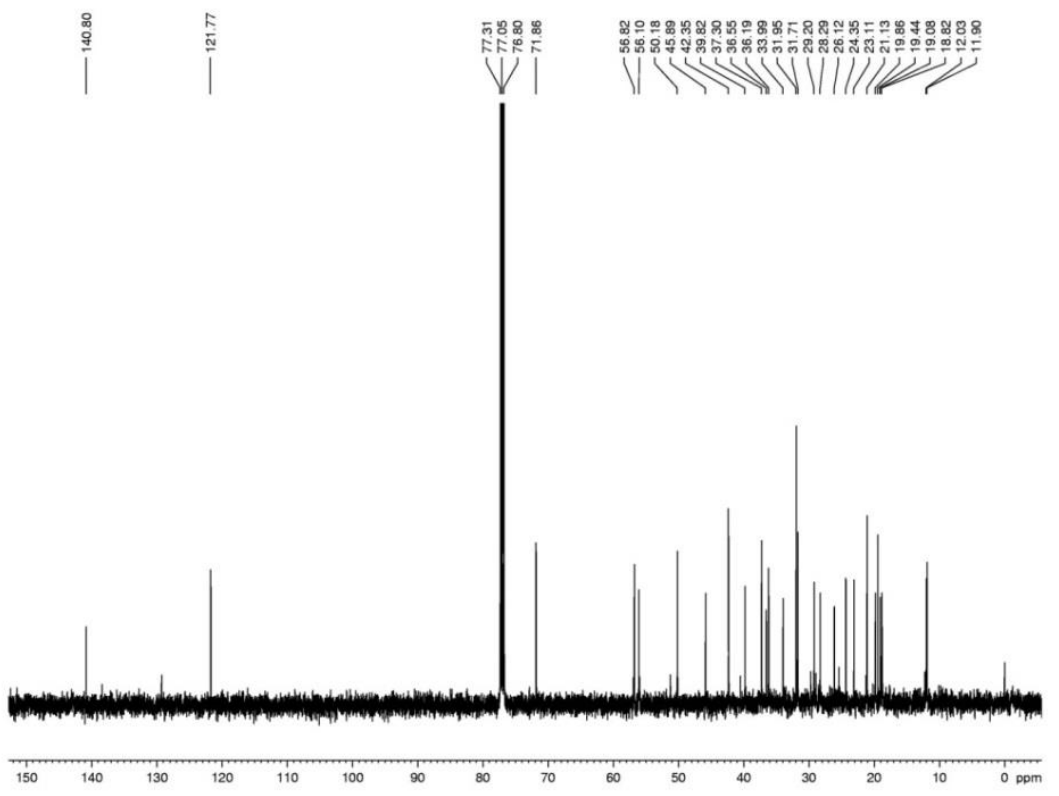

Fonte: Autoria própria. 


\section{CAPÍTULO 3}

Docking molecular 


\section{INTRODUÇÃO}

\subsection{Ferramenta de interação proteína-ligante: Docking molecular}

As metodologias de docking molecular são consideravelmente importantes para planejamento e descoberta de novos fármacos uma vez que fornecem informações de interações proteína-ligante e preveem a afinidade de uma pequena molécula (ligante) ao receptor de interesse (BALLANTE; MARSHALL, 2016), (GUEDES; MAGALHÃES, DARDENNE, 2014). O uso de informações estruturais possibilita a aplicação de Screening Virtual a fim de identificar potenciais ligantes para o desenvolvimento de novos fármacos. O principal método para investigar potenciais ligantes de alvos moleculares são as simulações de docking proteínaligante (DE AZEVEDO JÚNIOR, 2010), (XAVIER et al., 2016) Figura 49.

Figura 49 - Screening Virtual utilizando a ferramenta de docking molecular para a descoberta de drogas potenciais.

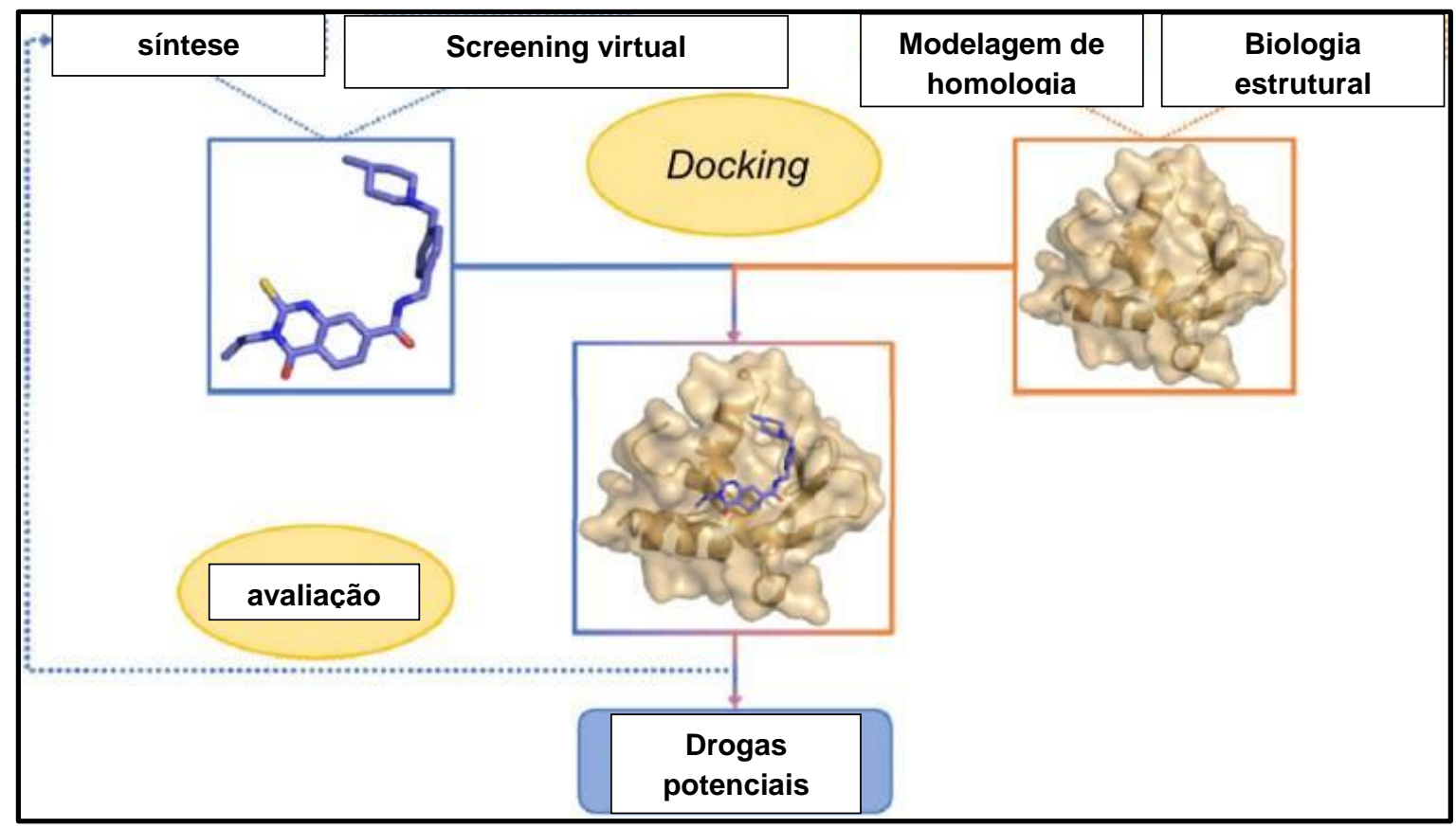

Fonte: Adaptado de Ruyck et al. (2016).

A ferramenta de docking molecular tem dois requisitos básicos: primeiro, são necessários dados estruturais da proteína alvo e do ligante e segundo, são necessários procedimentos para estimar as poses de interação do ligante no alvo 
assim como a força destas interações. Vários algorítimos estão disponíveis para prever as poses dos ligantes e classificá-las utilizando funções scoring implementadas em cada abordagem de docking. Estas funções podem prever a afinidade de ligação das poses dos ligantes (ELOKELY; DOERKSEN, 2013).

Segundo Xu, Huang e Zou (2018) o conhecimento adquirido do uso de produtos naturais para o tratamento de diversas doenças contribuiu para a descoberta de fármacos potenciais. Atualmente, o processo de desenho de drogas é dependente da suposição de Ehrlich, em que as drogas funcionam como "balas mágicas" modulando o alvo principal da doença. Grande sucesso foi alcançado com esta suposição, porém, nos últimos anos, emergiram várias desvantagens desta suposição, como, por exemplo, efeitos colateriais graves e toxicidade com risco de vida em ensaios clínicos.

No entanto, não há dúvidas de que as ferramentas computacionais têm contribuído bastante para a descoberta de novos fármacos, muitos destes já devidamente aprovados pelas autoridades competentes e de grande utilização para o tratamento de diversas doenças (IRWIN; SHOECHET, 2016). 


\section{OBJETIVOS}

\subsection{Objetivo Geral}

Realizar o screening virtual de 12 alcaloides frente à quinase humana CDK8 através da ferramenta de docking molecular.

\subsection{Objetivos Específicos}

- $\quad$ Selecionar estruturas cristalográficas de CDKs, para as quais há informação de Ki (constante de inibição), utilizando a base de dados PDB (Protein Data Bank);

- $\quad$ Filtrar os dados estruturais de CDKs;

- $\quad$ Testar diferentes protocolos de docking molecular para uma estrutura de CDK modelo (re-docking);

- Usar o melhor protocolo de docking para as outras estruturas cristalográficas (esemble-docking);

- Testar as funções scoring para avaliar a interação de CDKs com os ligantes;

- Identificar as principais interações intermoleculares CDK-ligante no screening virtual. 


\section{MATERIAIS E MÉTODOS}

\subsection{Análise computacional da interação proteína-ligante utilizando a ferramenta docking molecular}

\subsubsection{Conjunto de dados}

A partir de uma pesquisa no banco de dados PDB (Protein Data Bank) utilizando a classificação enzimática EC 2.7.11.22, buscou-se por estruturas cristlográficas de CDKs na presença de inibidores, os quais tivessem valores de constante de inibição (Ki) definidos (BERMAN et al., 2000), (BERMAN et al.,2002), (WESTBROOK et al., 2003). Foram encontradas moléculas de água cristalográficas numa esfera virtual de raio $15 \mathrm{~A}$ centrada no sítio de cada ligante.

O PDB reúne informações de três bancos de dados: Mother of All Databases (MOAD) (Hu et al., 2005), BindingDB (Liu et al., 2007) e PDBbind (Wang et al., 2004). A partir da busca realizada, 30 estruturas de CDKs foram identificadas, eliminando aqueles ligantes repetidos em diferentes conjunto de dados. Neste conjunto de dados, foram consideradas as estruturas da CDK2, CDK5 e CDK9. Esta pesquisa foi realizada em 28 de junho de 2017.

Foram utilizadas diferentes CDKs para desenvolver uma função que fosse comum para todas as CDKs, e não apenas para a CDK8. A partir deste conjunto de dados, foi desenvolvido um modelo matemático para prever a afinidade de ligação do ligante para a proteína alvo.

A fim de identificar potenciais inibidores de CDK8, um conjunto de dados de estruturas de CDK8 complexadas com ligantes foi construído. Para as estruturas cristalográficas de CDK8 disponíveis (pesquisa realizada em 28 de junho de 2017), não havia informação sobre Ki.

\subsubsection{Simulações de docking molecular}

A SAnDRreS é uma acronímia para Statistical Analysis of Docking Results and Scoring functions. É uma ferramenta computacional que foi desenvolvida utilizando a linguagem de programação Phyton (Versão 3). Faz a análise de dados gerados por um programa de docking e requer apenas a 
estrutura da proteína-ligante no formato PDB, ligantes no format SDF (Structure Data Format) e dados de docking e funções scoring no formato CSV (Comma Separated Values) (XAVIER et al., 2016).

Para todas as estruturas do conjunto de dados foi adotada a estratégia de docking molecular descrita por Xavier et al., (2016). Resumidamente, as simulações de docking molecular foram realizadas pelo softwere Molegro Virtual Docker (MVD) (HEBERLÉ; AZEVEDO, 2011), (THOMSEN; CHRISTENSEN, 2006). Todos os átomos de proteínas e ligantes foram preparados usando valores de carga padrão para o programa MVD. Entre as possíveis estruturas de CDKs, a de mais alta resolução foi escolhida como a mais adequada para as simulações de re-docking que consistiu na submissão desta estrutura a 32 protocolos de docking previamente estabelecidos. Para cada protocolo, foram geradas 1.000 poses. Os resultados de docking foram classificados usando as funções scoring adicionais implementadas no programa MVD.

Uma descrição completa das funções scoring foi publicada por De AZEVEDO JÚNIOR, 2010; KORB et al., 2009 e THOMSEN; CHRISTENSEN, 2006. O protocolo de docking mais promissor foi selecionado usando como critério o menor desvio quadrático médio (RMSD - Root Mean Square Desviation) e o maior coeficiente de correlação de Spearman $(\rho)$.

Depois de selecionar o protocolo, as demais estruturas do conjunto de dados foram submetidas ao mesmo protocolo para comparação. Este procedimento é referido como docking conjunto. As funções scoring foram calculadas utilizando o MVD para cada estrutura no conjunto e a posição cristalográfica do sítio ativo a fim de testar a precisão das funções scoring na previsão da afinidade de ligação (Ki). Enfatizou-se a posição cristalográfica para ter a informação mais confiável a fim de testar a capacidade de predição das funções scoring. As cargas dos átomos de proteínas e ligantes foram geradas usando o protocolo padrão disponível no programa MVD.

O melhor protocolo de docking identificado para o conjunto de dados de CDKs foi aplicado ao conjunto de dados da CDK8. As estruturas da CDK8 e os átomos de ligantes também foram preparados usando valores de carga padrão para o programa MVD. 


\subsubsection{Screening Virtual}

O conjunto de dados gerados pela ferramenta SAnDReS pode ser usado para testar a capacidade de um programa de encontrar ligantes ativos embutidos em um conjunto de dados. Para fazer isso, executou-se um Screening Virtual (SV), usando o melhor protocolo de docking, selecionado anteriormente pelo programa MVD, e classificaram-se os ligantes usando funções scoring MVD e funções scoring polinomial. Nesta análise, a SAnDReS calcula fatores de enriquecimento (EF Enrichment Factors) e gera curvas de características de operação do receptor (ROC - Receiver Operating Characteristics) para avaliação do desempenho da função scoring (BROOIJMANS; KUNTZ, 2003).

Além da validação do protocolo SV, o melhor protocolo de docking foi aplicado a um conjunto de dados de produtos naturais. Essas moléculas foram preparadas para SV como descrito anteriormente nas simulações de docking, utilizou-se a estrutura cristalográfica da CDK8 (código de acesso PDB 4F6U) (SCHNEIDER et al., 2013) como alvo para o SV com produtos naturais. A estrutura do ligante foi excluída da estrutura 4F6U e o VS foi centrado em $x=39,98 \hat{A}, y=$ $22,44 \AA$ e $z=102,64 \AA$.

A estrutura de maior resolução cristalográfica foi empregada para as simulações de re-docking, utilizando os 32 protocolos de docking previamente estabelecidos. Para cada protocolo, foram geradas 1000 poses. 


\section{RESULTADOS E DISCUSSÃO}

\subsection{Análise computacional e estatística dos parâmetros estruturais}

Usando a estrutura cristalográfica de maior resolução como critério de seleção, SAnDReS identificou a entrada 4ACM (Figura 50) (BERG et al., 2012) no conjunto de dados de CDKs, sendo geradas 1000 poses para cada protocolo de docking, como mostrado na Figura 50B.

A análise dos resultados para todos os 32 protocolos de docking indicou que o RMSD mais baixo foi obtido para o protocolo 4 , RMSD $=1,192 \AA$ ( $\rho=0,865, r^{2}=$ 0,850 e $p$-valor $<0,001$ ) (Figura $50 \mathrm{C}$ ). O ligante com score mais baixo e consequentemente, bem posicionado no sítio de ligação ao ATP são mostradas na Figura 50D. O protocolo 4 usa MolDock (Simplex Evolution) como mecanismo de pesquisa e MolDock Score como função scoring. Este protocolo foi utilizado para realizar simulações de docking para os demais conjuntos de dados de CDKs e para a CDK8.

Figura 50 - A) Estrutura cristalográfica $4 \mathrm{ACM}$, em verde está a esfera de docking centrada no ligante ativo. B) Resultados de Re-docking, onde tem-se um cluster de 1000 poses mostrado em vermelho. C) MolDock Score vs docking RMSD para a região de mais baixo score. D) Pose para o mais baixo MolDock Score (vermelho) e a posição cristalográfica para o ligante (cinza), como referência.
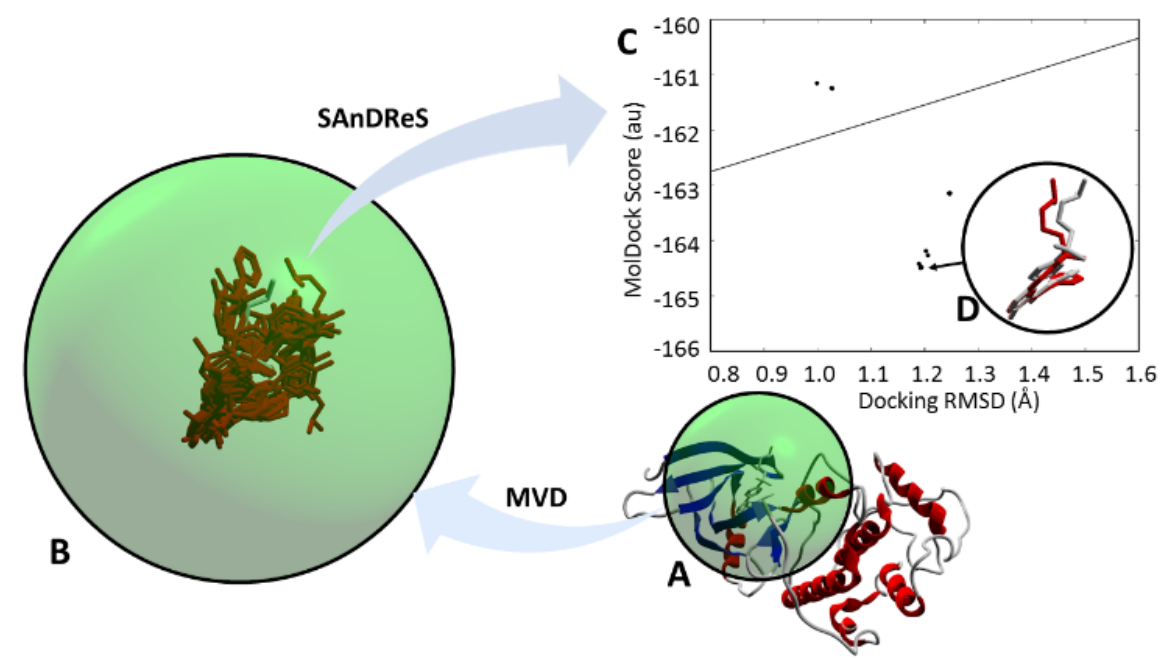

Fonte: Autoria própria. 
Aplicou-se o melhor protocolo de docking identificado no conjunto de dados de CDKs (protocolo 4) para o conjunto de dados da CDK8. Além disso foi observada uma correlação negativa moderada da MolDock Score com docking RMSD considerando as 22 estruturas no conjunto de dados da CDK8 com RMSD de -0,378 e $p$-value $=0,083$ (Figura $51 \mathrm{~B}$ ). Os resultados para as estruturas em ambos os conjuntos de dados indicam um bom nível de precisão de docking do protocolo 4 para a predição da posição do ligante, quando comparado aos dados publicados anteriormente para CDKs (MYSINGER et al., 2012). O protocolo 4 funcionou ainda melhor para o conjunto de dados da CDK8, que pode ser confirmado pela análise das estruturas da CDK8 que tiveram a maior precisão de docking observada.

Figura 51 - MolDock Score and docking RMSD. A) Dados para as CDKs. B) Dados para a CDK8.

A)

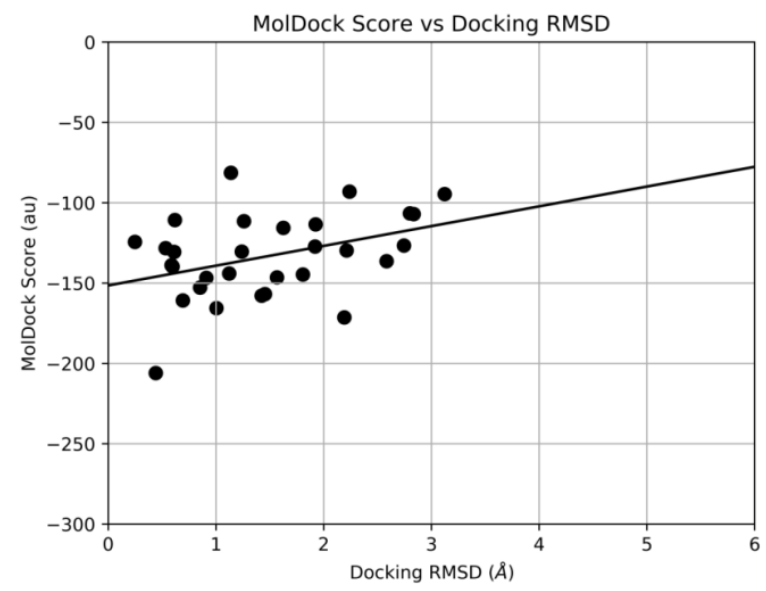

B)

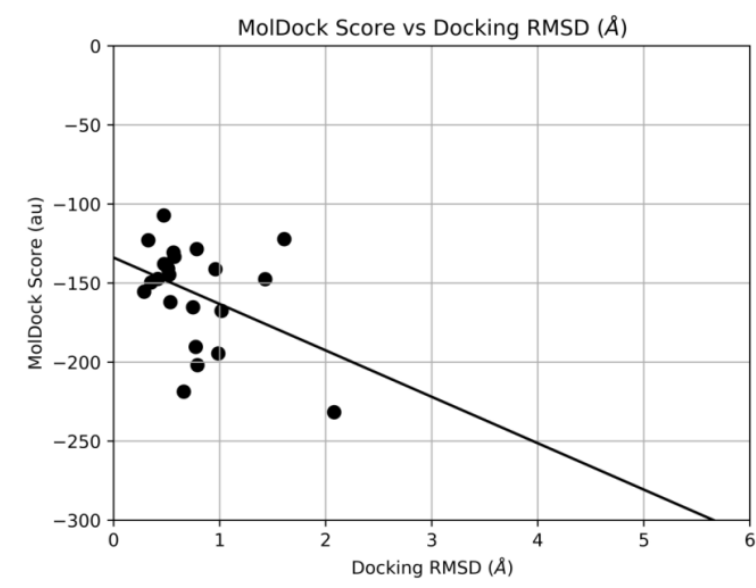

Fonte: Autoria própria. 
Para testar o desempenho das funções scoring na previsão de afinidade de ligação para as estruturas no conjunto de dados das CDKs, a análise da correlação entre afinidade de ligação experimental (log $(\mathrm{Ki})$ ) e as funções scoring foi realizada. Nenhuma das funções scoring MVD testadas aqui alcançou valores de $p$ abaixo de 0,05, que é o valor de corte para análise de sistemas biológicos.

A aplicação da metodologia da função scoring polinomial gerou um conjunto de novas equações polinomiais. O melhor resultado obtido foi para a função polinomial $308\left(r^{2}=0,196, p\right.$-value $=0,04431$ para o conjunto de treinamento) e $\left(r^{2}=\right.$ 0,296, $p$-value $=0,13$ para o conjunto de teste). A Tabela 19 mostra a análise estatística das funções scoring MVD e da função scoring polinomial 308 e a Figura 52A mostra o gráfico de dispersão para a função scoring polinomial 308 versus afinidade de ligação experimental $(\log (\mathrm{Ki})$ ), usando os dados do conjunto de treinamento. A equação polinomial 308 é a seguinte (Equação 1):

Score $308=-8,151306+-0,041651$ (Proteína) + 0,000920(Proteína.Água) + 0,00280 (Proteína.Eletro-longa) - 0,000247(Proteína ${ }^{2}$ )

\section{(Equação 1)}

A equação acima usa os scores proteína, água, eletro-longa e proteína ${ }^{2}$ como variáveis explanatórias.

Tabela 19 - Correlação entre funções scoring e $\log \left(\mathrm{K}_{\mathrm{i}}\right)$.

\begin{tabular}{ccccc}
\hline Scores & $\rho$ (treinamento) & $\rho$ (treinamento) & $\rho$ (teste) & $\rho$ (teste) \\
\hline Plantas & 0,134 & $5,631 \times 10^{-01}$ & 0,800 & $9,628 \times 10^{-03}$ \\
MolDock & 0,031 & $8,933 \times 10^{-01}$ & 0,667 & $4,987 \times 10^{-02}$ \\
Re-rank & 0,019 & $9,332 \times 10^{-01}$ & 0,817 & $7,225 \times 10^{-03}$ \\
Interação & 0,147 & $5,236 \times 10^{-01}$ & 0,667 & $4,987 \times 10^{-02}$ \\
Co-fator & 0,229 & $3,175 \times 10^{-01}$ & 0,479 & $1,918 \times 10^{-01}$ \\
Proteína & 0,175 & $4,470 \times 10^{-01}$ & 0,667 & $4,987 \times 10^{-02}$ \\
Água & $-0,321$ & $1,564 \times 10^{-01}$ & 0,100 & $7,980 \times 10^{-01}$ \\
Interno & $-0,079$ & $7,328 \times 10^{-01}$ & $-0,050$ & $8,984 \times 10^{-01}$ \\
Eletro & 0,332 & $1,409 \times 10^{-01}$ & $-0,411$ & $2,721 \times 10^{-01}$ \\
Eletro-longa & $-0,303$ & $1,820 \times 10^{-01}$ & $-0,383$ & $3,084 \times 10^{-01}$ \\
Ligação de H & 0,384 & $8,557 \times 10^{-02}$ & 0,283 & $4,600 \times 10^{-01}$ \\
LE1 & $-0,165$ & $4,748 \times 10^{-01}$ & 0,100 & $7,980 \times 10^{-01}$ \\
LE3 & $-0,032$ & $8,889 \times 10^{-01}$ & $-0,017$ & $9,661 \times 10^{-01}$ \\
Polscore308 & 0,478 & $2,837 \times 10^{-02}$ & 0,750 & $1,994 \times 10^{-02}$ \\
\hline
\end{tabular}

Fonte: Autoria própria.

A presença da água na função scoring polinomial indica a importância da interação mediada pela água para a ligação do ligante nas CDKs, conforme relatado 
anteriormente para a CDK2 (DE AZEVEDO-JÚNIOR, 1996), (DE AZEVEDO, 1997). A Figura 52B mostra as posições de água cristalográficas comumente encontradas no bolso de ligação ao ATP.

Especificamente para a função scoring polinomial 308, o escore da proteína tem uma contribuição importante para a afinidade de ligação, provavelmente devido à prevalência de interações eletrostáticas no bolso de ligação da CDK. A Figura 52C mostra a superfície molecular eletrostática para o bolso de ligação ao ATP para CDK2 (código de acesso PDB: 4ACM), onde percebe-se claramente a concentração de carga. Este bolso de ligação carregado deve-se principalmente aos resíduos Lys33, Glu81, Asp86, Asn132 e Asp145. Estes resíduos são conservados nas estruturas de CDK5 e CDK9.

Além disso, a função score polinomial 308 também tem um termo para explicar interações eletro-longas $(r>4,5 \AA$ ), o que destaca ainda a importância das interações eletrostáticas para a ligação do ligante às CDK2, CDK5 e CDK9. Estudos recentes, utilizando simulações de dinâmica molecular, também mostraram a importância das interações eletrostáticas para a ligação do ligante às CDK2 e CDK4 (CHOHAN et al., 2016), (JAYARAMAN; JAMIL, 2014).

Os ligantes ativos identificados nas 30 estruturas foram utilizados no conjunto de dados de CDKs e adicionados mais 270 ligantes selecionados aleatoriamente. Realizou-se o SV usando MVD e o protocolo 4 para este conjunto de dados. Os resultados de SV foram utilizados para calcular as curvas de fatores de enriquecimento - EF e de caracteríticas de operação do receptor - ROC.

A equação polinomial 308 exibiu melhor desempenho em comparação às funções scoring originais, com melhores coeficientes de correlação e valores de $p$ para conjuntos de treinamento e teste, exibindo os melhores EFs (Fatores de enriquecimento) e área sobre a curva (AUC - Area Under Curve) quando comparado às funções scoring originais ( $\mathrm{AUC}=74,06 \%$ e $E F=50,0)$ (Tabela 20). A curva ROC é mostrada na Figura 52D. Além disso, a função scoring polinomial 308 também mostrou melhor desempenho em comparação com dados previamente publicados para CDKs (EFmax $=19,8)$, o que indica claramente o potencial de usar funções scoring polinomiais para prever afinidade de ligação do ligante e para escanear conjuntos de dados para estudos de SV (HUANG; SHOICHET, 2006), (MYSINGER et al., 2012). 
Figura 52 - A) $\log \left(\mathrm{K}_{\mathrm{i}}\right)$ predito versus $\log \left(\mathrm{K}_{\mathrm{i}}\right)$ observado. Os valores para $\log \left(\mathrm{K}_{\mathrm{i}}\right)$ predito foram calculados usando a equação polinomial 308. B) Moléculas de água cristalográficas no sítio de ligação ao ATP indicados pelos pontos vermelhos. Resíduos carregados e envolvidos em interações intermoleculares também são indicados. C) Superfície eletrostática molecular para o sítio de ligação ao ATP. Superfícies carregadas positivamente e negativamente são mostradas em azul e vermelho, respectivamente. Superfícies neutras são indicadas em branco. D) Curva ROC para SV com ligantes ativos são mostrados em vermelho. A linha tracejada é para dados aleatórios. Figuras $A$ e $C$ foram obtidas usando o programa MVD (THOMSEN; CHRISTENSEN, 2006) e considerando a estrutura 4ACM (BERG et al., 2012).

\section{A}
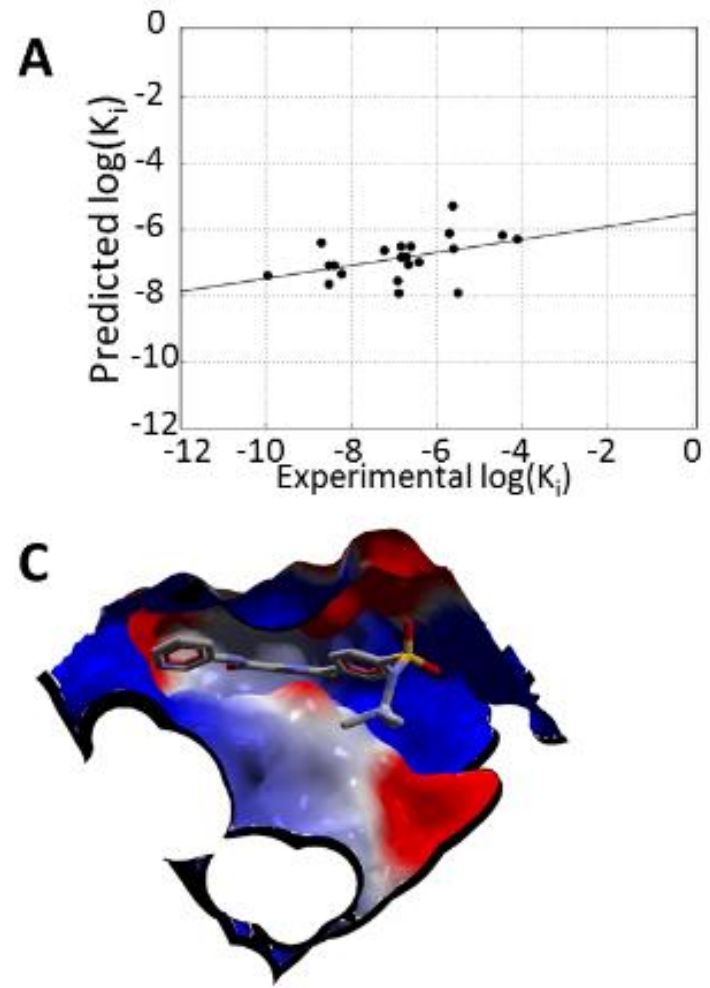

B
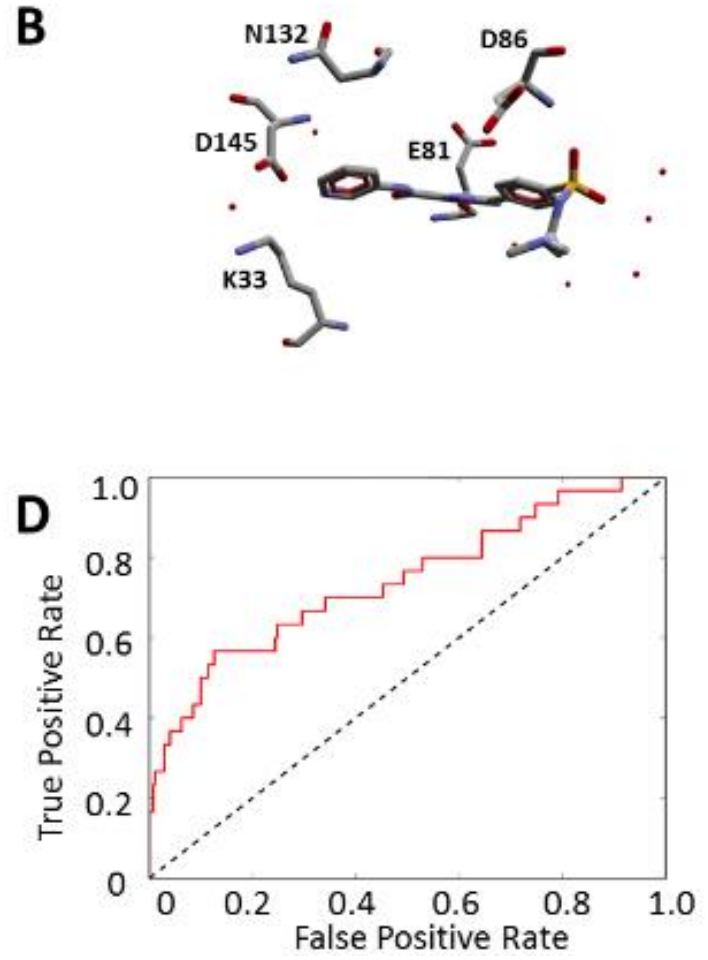

Fonte: Autoria própria. 
Tabela 20 - Correlação entre funções scoring e afinidade de ligação experimental $\log \left(\mathrm{K}_{\mathrm{i}}\right)$.

\begin{tabular}{lcccccc}
\hline Função Scoring & $\boldsymbol{p}$ & $\boldsymbol{p}-\mathbf{1}$ & $\mathbf{r}^{\mathbf{2}}$ & $\boldsymbol{p - 2}$ & AUC & EF $_{\max }$ \\
\hline Plantas Score & 0,253 & $1,766 \times 10^{-01}$ & 0,027 & $3,874 \times 10^{-01}$ & 60,419 & 5,0 \\
MolDock Score & 0,200 & $2,887 \times 10^{-01}$ & 0,052 & $2,234 \times 10^{-01}$ & 65,370 & 5,0 \\
Re-rank Score & 0,216 & $2,510 \times 10^{-01}$ & 0,077 & $1,369 \times 10^{-01}$ & 66,951 & 20,0 \\
Interação Score & 0,225 & $2,325 \times 10^{-01}$ & 0,047 & $2,479 \times 10^{-01}$ & 66,568 & 20,0 \\
Co-factor Score & 0,282 & $1,310 \times 10^{-01}$ & 0,020 & $4,571 \times 10^{-01}$ & 50,000 & 20,0 \\
Proteína Score & 0,270 & $1,485 \times 10^{-01}$ & 0,063 & $1,793 \times 10^{-01}$ & 68,136 & 20,0 \\
Água Score & $-0,336$ & $6,937 \times 10^{-02}$ & 0,099 & $9,059 \times 10^{-02}$ & 47,235 & 2,0 \\
Interno Score & 0,022 & $9,071 \times 10^{-01}$ & 0,003 & $7,789 \times 10^{-01}$ & 44,111 & 0,53 \\
Eletro Score & 0,148 & $4,347 \times 10^{-01}$ & 0,087 & $1,134 \times 10^{-01}$ & 61,333 & 20,0 \\
Eletro Long Score & $-0,307$ & $9,916 \times 10^{-02}$ & 0,047 & $2,516 \times 10^{-01}$ & 35,309 & 2,0 \\
Ligação H Score & 0,221 & $2,399 \times 10^{-01}$ & 0,075 & $1,444 \times 10^{-01}$ & 51,309 & 2,0 \\
LE1 Score & $-0,124$ & $5,149 \times 10^{-01}$ & 0,002 & $8,070 \times 10^{-01}$ & 60,420 & 0,71 \\
LE3 Score & $-0,007$ & $9,721 \times 10^{-01}$ & 0,019 & $4,626 \times 10^{-01}$ & 60,185 & 2,5 \\
Referência & $\mathrm{ND}$ & $\mathrm{ND}$ & $\mathrm{ND}$ & $\mathrm{ND}$ & $\mathrm{ND}$ & 19,8 \\
\hline
\end{tabular}

$\mathrm{p}-1$ está relacionado a $p$

$\mathrm{p}$-2 está relacionado a $\mathrm{r}^{2}$

AUC: Área sobre a curva (Area Under Curve - AUC)

$E_{\text {max }}$ : Valor máximo do fator de enriquecimento (Enrichment Factor - EF)

ND: Não disponível

$p$ and $r^{2}$ foram estimados para as 30 estruturas de CDK

AHUANG; SHOICHET; IRWIN, (2006).

Fonte: Autoria própria.

\subsection{Screening Virtual com Produtos Naturais}

No SV (Screening Virtual) frente a CDK8, utilizamos a estrutura da CDK8 (4F6U) e 12 produtos naturais (Fig. 53) previamente isolados da espécie vegetal Waltheria brachypetala (LIMA, 2012). O melhor resultado está apresentado na Figura 54. A afinidade de ligação estimada [log (Ki)] com o escore 308 é -7,12, próxima à obtida para o ligante da CDK2 (código PDB: 1PXM; -7,22) no conjunto de dados CDK. A Tabela 21 mostra a afinidade de ligação prevista para as 12 moléculas. A análise das interações intermoleculares (Fig. 54) entre Waltheriona-E e CDK8 indica a participação de Lys52, Glu66, Leu70, Phe97, Ala172 e Asp173. As ligações intermoleculares de hidrogênio envolvem a participação da cadeia lateral de Glu66 e átomos de cadeia principal de Asp173. Conforme observado anteriormente em estudos recentes de simulação (FUJIMOTO et al., 2017), (ONO et al., 2017), (WANG et al., 2017), o resíduo Phe97 é próximo ao ligante e atua como um "porteiro" no bolso de ligação ao ATP. 
Figura 53 - Estrutura dos produtos naturais utilizados no screening virtual frente à proteína CDK8.<smiles>[R]C1C[C@H](CCCCCC)c2c(n([R7])c(C)c(OC)c2=O)C1[R]</smiles>

$\mathrm{R} 1 \quad \mathrm{R} 2 \quad \mathrm{R} 3$<smiles>[R]CCCC[C@H]1CCCc2c1c(OC)c(OC)c(C)[n+]2[O-]</smiles>

$\mathrm{R}$

(8)

(9)
$n$-Propyl

Phenyl<smiles>[R]CCCCC[C@H]1CCCc2c1c(=O)c(OC)c(C)n2OC</smiles>

R

(10) Phenyl

(11) $n$-Propyl

(3) $\mathrm{H} \mathrm{OH} \mathrm{H}$

(4) $\mathrm{H} \quad \mathrm{OCH}_{3} \mathrm{H}$

(6) $\quad \mathrm{CH}_{3}=\mathrm{O} \quad \mathrm{H}$

(7) $\mathrm{H} \mathrm{H} \mathrm{H}$<smiles>COc1c(C)nc2ccc3c(c2c1OC)C1CCC(O)[C@]3(c2ccccc2)O1</smiles>

(5)<smiles>COc1ccccc1C1(O)CCC[C@@H]2O[C@H]1c1ccc3nc(C)c(OC)c(OC)c3c12</smiles>

(12)

Fonte: Autoria própria. 
Figura 54 - Principais resíduos da CDK8 envolvidos em interações intermoleculares com o ligante Waltheriona-E.

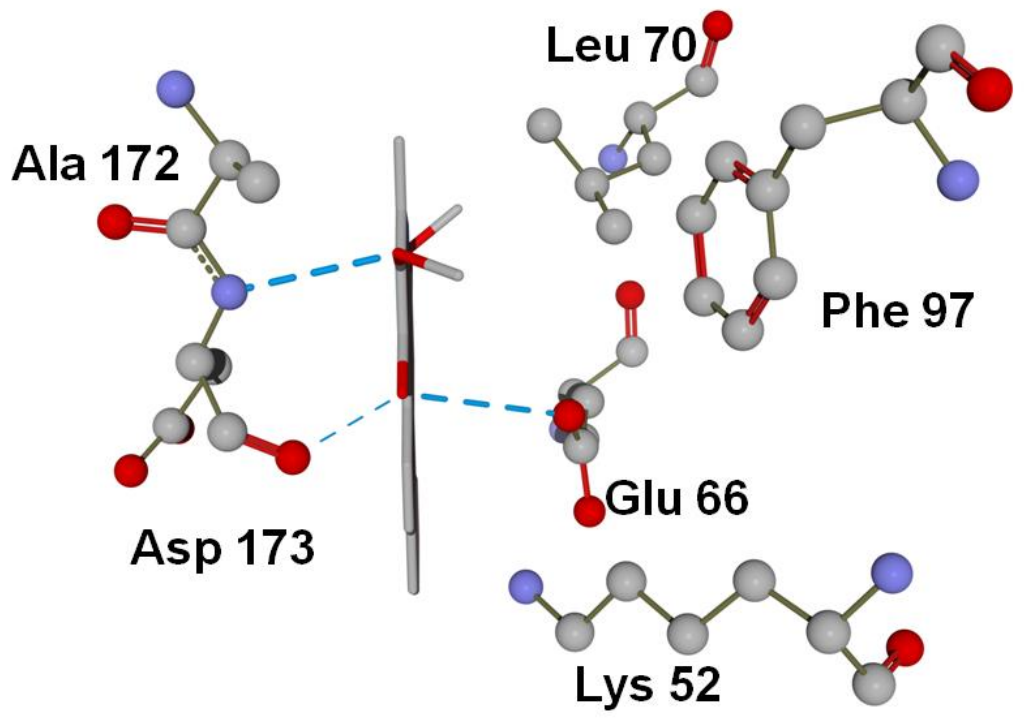

Fonte: Autoria própria. 
Tabela 21 - Valores de afinidade de ligação preditos pelo MVD e funções scoring Polscore\#308. Posições dos ligantes para predição de valores da afinidade de ligação foram obtidos usando o protocolo 4 para o MVD.

\begin{tabular}{|c|c|c|c|c|c|c|c|c|c|c|c|c|}
\hline Ligante & $\begin{array}{c}\text { MolDock } \\
\text { Score }\end{array}$ & $\begin{array}{l}\text { Score } \\
\text { Re- } \\
\text { Rank }\end{array}$ & $\begin{array}{l}\text { Score } \\
\text { interação }\end{array}$ & $\begin{array}{l}\text { Score } \\
\text { proteína }\end{array}$ & $\begin{array}{l}\text { Score } \\
\text { água }\end{array}$ & $\begin{array}{l}\text { Score } \\
\text { interno }\end{array}$ & $\begin{array}{l}\text { Score } \\
\text { eletro }\end{array}$ & $\begin{array}{l}\text { Score eletro } \\
\text { longa }\end{array}$ & $\begin{array}{l}\text { Score } \\
\text { ligação } \\
\text { H }\end{array}$ & Score LE1 & $\begin{array}{l}\text { Score } \\
\text { LE3 }\end{array}$ & $\begin{array}{l}\text { Polscore } \\
\# 0000308\end{array}$ \\
\hline Antidesmona (1) & $-122,115$ & -708.436 & $-157,126$ & $-145,736$ & $-809,133$ & 35,011 & 0 & 0 & $-451,068$ & $-530,936$ & $-308,016$ & $-8,17335$ \\
\hline Chamaedrona (2) & $-121,5$ & $-697,199$ & $-156,342$ & $-145,46$ & $-808,627$ & 348,425 & 0 & 0 & $-448,971$ & $-528,259$ & $-30,313$ & $-5,8108$ \\
\hline Hyeronimona (3) & $-121,466$ & $-690,586$ & $-156,308$ & $-145,405$ & $-811,103$ & 348,421 & 0 & 0 & $-453,915$ & $-528,114$ & $-300,255$ & $-7,03257$ \\
\hline Waltheriona E (4) & $-119,434$ & $-764,308$ & $-163,615$ & $-152,698$ & $-813,694$ & 441,814 & 0 & 0 & $-455,841$ & $-49,764$ & $-318,462$ & $-7,12675$ \\
\hline 10-hydroxi-waltheriona C (5) & $-115,125$ & $-554,782$ & $-161,592$ & $-149,938$ & $-353,994$ & 464,672 & 0 & 0 & $-495,715$ & $-426,389$ & $-205,475$ & $-6,42217$ \\
\hline $\mathrm{N}$-metil-antidesmona (6) & $-111,489$ & $-721,639$ & $-157,356$ & $-147,451$ & $-793,759$ & 458,663 & 0 & 0 & $-476,501$ & $-464,538$ & $-300,683$ & $-8,89964$ \\
\hline 8-desoxiantidesmona (7) & $-110,888$ & $-664,445$ & $-152,043$ & $-140,599$ & $-81,278$ & 411,557 & 0 & 0 & $-45,235$ & $-504,035$ & $-302,021$ & $-6,09829$ \\
\hline Waltheriona J (8) & $-108,038$ & $-82,834$ & $-156,594$ & $-146,358$ & $-791,591$ & 485,568 & 0 & 0 & $-487,108$ & $-450,157$ & $-345,142$ & $-5,70974$ \\
\hline Brachytelona (9) & $-101,929$ & $-844,305$ & $-157,175$ & $-145,108$ & $-395,452$ & 552,467 & 0 & 0 & 0,949921 & $-424,702$ & $-351,794$ & $-6,54805$ \\
\hline Waltheriona G (10) & $-899,505$ & 298,377 & $-150,337$ & $-139,232$ & 0,549058 & 603,866 & 0 & 0 & $-73,059$ & $-33,315$ & 11,051 & $-8,03575$ \\
\hline Waltheriona L (11) & $-899,079$ & $-35,475$ & $-157,774$ & $-146,651$ & $-572,274$ & 678,657 & 0 & 0 & $-541,255$ & $-332,992$ & $-131,389$ & $-6,86026$ \\
\hline 4-O-metil-waltherione A (12) & 882,262 & 353,559 & $-154,291$ & $-146,766$ & 0,226016 & 1036,55 & 0 & 0 & $-157,273$ & 294,087 & 0,117853 & $-9,44394$ \\
\hline
\end{tabular}

Fonte: Autoria própria. 


\section{CONCLUSÃO}

$\checkmark$ Devido à importância dos resultados de docking para os estágios iniciais da descoberta de medicamentos, acreditamos que o SAnDReS é uma ferramenta computacional com potencial para melhorar a precisão em projetos de docking.

$\checkmark$ Além disso, a análise de potenciais novos inibidores de CDK8 utilizado uma biblioteca com produtos naturais possibilitou a identificação da molécula waltheriona E com a afinidade de ligação estimada e próxima a afinidade de inibidores de CDKs descritos anteriormente. A análise da interação intermolecular entre waltheriona $\mathrm{E} \mathrm{e}$ CDK8 indicou características comuns anteriormente observadas para inibidores de CDK8.

$\checkmark \mathrm{O}$ isolamento de metabólitos das folhas de $W$. brachypetala resultou na identificação de um alcaloide (Brachytelona $A$ ), um flavonoide (metoxicatequina), uma mistura de triterpenoides (betulina e eritrodiol) e uma mistura de esteroides (sitosterol e estigmasterol). Destes, o alcaloide brachytelona $A$, candidato ao screening virtual frente à proteína $C D K 8$, apresentou $\log \mathrm{Ki}=-6,54$, um valor abaixo do encontrado para o alcaloide waltheriona $E(-7,12)$ já previamente isolado pelo grupo de pesquisa da Profa. Dra. Maria Fátima das Graças Fernandes da Silva, do departamento de química da Ufscar.

$\checkmark$ Houve expressão da proteína CDK8 utilizando a linhagem de células Rosetta(DE3) a $18{ }^{\circ} \mathrm{C}, 20^{\circ} \mathrm{C}$ e a $37^{\circ} \mathrm{C}$, no entanto, houve um maior padrão de expressão nas duas primeiras temperaturas, embora a CDK8 permaneça predominantemente na fração insolúvel do lisado.

$\checkmark \quad$ O protocolo de solubilização por SDS $2 \%$ mostrou-se efetivo enquanto que 0 protocolo que utiliza o TFE (trifuoroetanol) não foi eficaz para a CDK8, o que nos encorajou a prosseguir os ensaios de purificação da CDK8 em condições desnaturantes com posterior reenovelamento.

$\checkmark \quad$ A CDK8 8 -HisTag, contida em corpos de inclusão, devidamente solubilizada com SDS 2\%, pôde ser reenovelada e purificada por Cromatografia Líquida de Alta Eficiência, utilizando coluna de $\mathrm{Ni}^{2+}$. Este é o primeiro relato de reenovelamento da CDK8, utilizando a proteína expressa em sistema bacteriano (E. coll). 
$\checkmark \quad$ A análise por dicroísmo circular mostrou que a CDK8-HisTag nativa contém $13,0 \%$ de hélices $\alpha ; 31,9 \%$ de folhas $\beta ; 35,4 \%$ de regiões randômicas e $20,1 \%$ de voltas $\beta$.

$\checkmark \quad$ A análise por fluorimetria da CDK8-HisTag mostrou que a mesma apresenta um comprimento de onda máximo de emissão em torno de $360 \mathrm{~nm}$. 


\section{REFERÊNCIAS BIBLIOGRÁFICAS}

AKOULITCHEV, S.; CHUIKOU, S.; REINBERG, D. TFIIH is negatively regulated by the CDK8 - containing mediador complexes. Nature, v. 407, p.102-106, 2000.

ALARCÓN, C.; ZAROMYTIDOU, A. I.; XI, Q.; GAO, S.; YU, J.; FUJISAWA, S.; BARLAS, A.; MILLER, A. N.; MANOVA-TODOROVA, K.; MACIAS, M. J.; SAPKOTA, G.; PAN, D.; MASSAGUÉ, J. Nuclear CDKs drive Smad transcriptional activation and turnover in BMP and TGF-beta pathways. Cell, v. 139, p. 757-769, 2009.

ALBERTS, B.; JOHNSON, A.; LEWIS, J.; RAFF, M.; ROBERTS, K.; WALTER, P. Biologia Molecular da célula. Artmed, 2010. $1396 \mathrm{p}$.

BALLANTE, F.; MARSHALL, G. R. An Automated Strategy for Binding-Pose Selection and Docking Assessment in Structure-Based Drug Design. Journal of. Chemical Information and Modeling, v. 56, p. 54-72, 2016.

BANCEREK, J.; POSS, Z. C.; STEINPARZER, I.; SEDLYAROV, V.; PFAFFENWIMMER, T.; MIKULIC, I.; DÖLKEN, L.; STROBL, B.; MÜLLER, M.; TAATJES, D. J.; KOVARIK, P. CDK8 kinase phosphorylates transcription factor STAT1 to selectively regulate the interferon response. Immunity, v. 38, p. 250-262, 2013.

BEAUCHARD, A.; FERANDIN, Y.; FRERE, S.; LOZACH, O.; BLAIRVACQ, M.; MEIJER, L.; THIERYA, V.; BESSONA, T. Synthesis of Novel 5-Substituted Indirubins as Protein Kinases Inhibitors. Bioorganic \& Medicinal Chemistry, v. 14, n. 18, p. 6434-6443, 2006.

BERG, S.; BERGH, M.; HELLBERG, S.; HÖGDIN, K.; LO-ALFREDSSON, Y.; SÖDERMAN, P.; VON BERG, S.; WEIGELT, T.; ORMÖ, M.; XUE, Y.; TUCKER, J.; NEELISSEN, J.; JERNING, E.; NILSSON, Y.; BHAT, R. Discovery of novel potent and highly selective glycogen synthase kinase-3 $\beta$ (GSK3 $\beta$ ) inhibitors for Alzheimer's disease: design, synthesis, and characterization of pyrazines Journal of Medicinal Chemistry, v. 55, p. 9107-9119, 2012.

BERMAN, H. M.; BATTISTUZ, T.; BHAT, T.N.; BLUHM, W. F.; BOURNE, P. E.; BURKHARDT, K.; FENG, Z.; GILLILAND, G. L.; IYPE, L.; JAIN, S.; FAGAN, P.; MARVIN, J.; PADILLA, D.; RAVICHANDRAN, V.; SCHNEIDER, B.; THANKI, N.; WEISSIG, H.; WESTBROOK, J. D.; ZARDECKI, C. The Protein Data Bank. Acta Crystallographica Seccion D Biological Crystallography, v. 58, p. 899-907, 2002. 
BERMAN, H. M.; WESTBROOK, J.; FENG, Z.; GILLILAND, G.; BHAT, T. N.; WEISSIG, H.; SHINDYALOV, I. N.; BOURNE, P. E. The Protein Data Bank. Nucleic Acids Research, v. 28, p. 235-242, 2000.

BODY, S. C.; M.B., Ch.B., M.P.H. Genomics: Implications for anesthesia, perioperative care and outcomes. Advances in Anesthesia, v. 27, n. 1, p. 73-94, 2009.

BÖHM, G.; MUHR, R.; JAENICKE, R. Quantitative analysis of protein far UV circular dichroism spectra by neural networks. Protein Engineering, v. 5, n. 3, p. 191-195, 1992.

BOURBON, H.; AGUILERA, A.; ANSARI, A. Z. A unified nomenclature for protein subunits of Mediator complexes linking transcriptional regulators to RNA polymerase II. Molecular Cell, v. 14, p. 553-557, 2004.

BREGMAN, D. B.; PESTEL, R. G.; KIDD, V. L. Cell cycle regulation and RNA polymerase II. Frontiers in Bioscience, v. 05, p. 244-257, 2000.

BROOIJMANS, N.; KUNTZ, I. D. Molecular recognition and docking algorithms.

Annual Review. Biophysics and Biomolecular Structure, v. 32, p. 335-373, 2003.

BUSKE, A., SCHIMIDT, J., BRINGMANN, G., ADAN, G., BUSEMANN, S., MUEHLBCHER, J., PORZEL, A. Antidesmone, a novel type isoquinoline alkaloid from Antidesma membranaceum (Euphorbiaceae). Tetrahedron, v. 55, p. 1079 1086,1999 .

CEE, V. J.; CHEN, D. Y. K.; LEE, M. R.; NICOLAOU, K. C. Cortistatin A is a Hightaffinity ligand of protein kinases rock, cdk8 and cdk11. Angewandte Chemie International Edition, v. 48, p. 8952-8957, 2009.

CHIN, L. S.; MURRAY, S. F.; DOHERTY, P. F.; SINGH, S. K. K252a Induces Cell Cycle Arrest and Apoptosis by Inhibiting Cdc2 and Cdc25c. Cancer Investigation, v. 17, p. 391-395, 1999.

CHOHAN, T. A.; CHEN, J. J.; QIAN, H. Y., PAN, Y. L.; CHEN, J. Z. Molecular modeling studies to characterize $\mathrm{N}$-phenylpyrimidin-2-amine selectivity for CDK2 and CDK4 through 3D-QSAR and molecular dynamics simulations. Molecular Biosystems, v. 12, 2016. 
CIMINO, G.; DE ROSA, S.; DE STEFANO, S.; MAZZARELLA, L.; PULITI, R.; SODANO, G. Isolation and X-ray Crystal Structure of a Novel Bromo Compound from Two Marine Sponges. Tetrahedron Letters, v. 23, p. 767-768, 1982.

CUI, C. B.; UBUKATA, M.; KAKEYA, H.; ONUSE, R.; OKADA, I.; TAKAHASHI, K.; ISONO, K.; OSADA, H. Acetophthalidin, a Novel Inhibitor of Mammalian Cell Cycle, Produced by a Fungus Isolated from a Sea Sediment. The Journal of Antibiotics (Tokyo), v. 49, p. 216-219, 1996.

DE AZEVEDO-JÚNIOR, W. F.; MUELLER-DIECKMANN, H. J.; SCHULZEGAHMEN, U.; WORLAND, P. J.; SAUSVILLE, E.; KIM, S. H. Structural basis for specificity and potency of a flavonoid inhibitor of human CDK2, a cell cycle kinase. Proceedings of the National Academy Sciences, v. 93, p. 2735-2740, 1996.

DE AZEVEDO, W. F.; LECLERC, S.; MEIJER, L.; HAVLICEK, L.; STRNAD, M.; KIM, S. H. Inhibition of cyclin-dependent kinases by purine analogues: crystal structure of human cdk2 complexed with roscovitine. European Journal Biochemistry, v. 243,p. 518-26, 1997.

DE AZEVEDO-JÚNIOR, W. F.; MoIDock applied to structure-based virtual screening. Current Drug Targets, v. 11, p. 327-334, 2010.

DEVLIN, T. M. Manual de bioquímica com correlações clínicas. Blucher, 2011, $1296 \mathrm{p}$.

DEWICK, M. P. Natural Products: a biosynthetic approach. 3. ed. Wiley, 2011. $550 \mathrm{p}$.

DOONAN, J. H.; KITSIOS, G. Functional evolution of cyclin-dependent kinases. Molecular Biotechnology, v. 42, p. 14-29, 2009.

DONNER, A. J.; SZOSTEK, S.; HOOVER, J. M.; ESPINOSA, J. M. CDK8 is a stimulus-specific positive coregulator of p53 target genes. Molecular Cell, v. 27, p. 121-133, 2007.

ECHALIER, A.; ENDICOTT, J. A.; NOBLE, M. E. M. Recent developments in cyclindependent kinase biochemical and structural studies. Biochimica Biophysica Acta, v. 1804, p. 511-519, 2010. 
ELOKELY, K. M.; DOERKSEN, R. J. Docking challenge: Protein sampling and molecular docking performance. Journal of Chemical Information and Modeling, v. 53, n. 8, p. 1934-1945, 2013.

FIRESTEIN, R.; BASS, A. J.; KIM, S. Y.; DUNN, J. F.; SILVER, S. J.; GUNEY, I.; FREED, E.; LIGON, A. H.; VENA, N.; OGINO, S.; CHHEDA, M. G.; TAMAYO, P.; FINN, S.; SHRESTHA, Y.; BOEHM, J. S.; JAIN, S.; BOJARSKI, E.; MERMEL, C.; BARRETINA, J.; CHAN, J. A.; BASELGA, J.; TABERNERO, J.; ROOT, D. E.; FUCHS, C. S.; LODA, M.; SHIVDASANI, R. A.; MEYERSON, M.; HAHN, W. C. CDK8 is a colorectal câncer oncogene that regulates $\beta$-catenin activity. Nature, $v$. 455, p. 547-551, 2008.

FIRESTEIN, R.; HAHN, W. C. Revving the throttle on an oncogene: CDK8 takes the driver seat. Cancer Research, v. 69, p. 7899-7901, 2009.

FIRESTEIN, R.; SHIMA, K.; NOSHO, K.; IRAHARA, N.; BABA, Y.; BOJARSKI, E.; GIOVANNUCCI, E. L.; HAHN, W. C.; FUCHS, C. S.; OGINO, S. CDK8 Expression in 470 Colorectal Cancers in Relation to $\beta$ - Catenin Activation, Other Molecular Alterations and Patient Survival. International Journal of Cancer, v. 126, n. 12, p. 2863-2873, 2010.

FUJIMOTO, J.; HIRAYAMA, T.; HIRATA, Y.; HIKICHI, Y.; MURAI, S.; HASEGAWA, M.; HASEGAWA, Y.; YONEMORI, K.; HATA, A.; AOYAMA, K.; CARY, D. R Studies of CDK 8/19 inhibitors: Discovery of novel and selective CDK8/19 dual inhibitors and elimination of their CYP3A4 time-dependent inhibition potential. Bioorganic Medicinal Chemistry, v. 25, p. 3018-3033, 2017.

FURUMOTO, T.; TANAKA, A.; ITO, M.; MALIK, S.; HIROSE, Y.; HANAOKA, F.; OHKUMA, Y. A kinase subunit of the human mediador complex, cdk8, positively regulates transcriptional activation. Genes to cells, v.12, p. 119-132, 2007.

FURUSAKI, A.; HASHIBA, N.; MATSUMOTO, T.; HIRANO, A.; IWAI, Y.; OMURA, S. The Crystal and Molecular Structure of Staurosporine, a New Alkaloid from a Streptomyces Strain. Bulletin of the Chemical Society of Japan, v. 55, p. 36813685, 1982.

GALBRAITH, M. D.; ALLEN, M. A.; BENSARD, C. L.; WANG, X.; SCHWINN, M. K.; QIN, B.; LONG, H. W.; DANIELS, D. L.; HAHN, W. C.; DOWELL, R. D.; ESPINOSA, J. M. HIF1A employs CDK8-mediator to stimulate RNAPII elongation in response to hypoxia. Cell, v. 153, p. 1327-1339, 2013. 
GENG, X.; CHANG, X. High-performance hydrophobic interaction cromatography as a tool for protein refolding. Journal of Cromatography, v. 599, p. 185-194, 1992.

GNATT, A. L.; CRAMER, P.; FU, J.; BUSHNELL, D. A.; KORNBERG, R. D. Structural basis of transcription: an RNA polymerase II elongation complex at 3.3 A resolution. Science, v. 292, n. 5523, p. 1876-1882, 2001.

GUEDES, I. A.; MAGALHÃES, C. S.; DARDENNE, L. E. Receptor-ligand molecular docking. Biophysical Reviews, v.6, n. 1, p. 75-87, 2014.

GREY, J.; THOMPSON, D. Challenges and Opportunities for New Protein Crystallization Strategies in Structure-Based Drug Design. Expert Opin Drug Discovery, v. 5, p. 1039-1045, 2011.

GUARDAVACCARO, D.; PAGANO, M. Stabilizers and destabilizers controlling cell cycle oscillators. Molecular Cell, v. 22, p. 1-4, 2006.

HANAHAN, D.; WEINBERG, R. A. The hallmarks of câncer. Cell, v. 100, p. 57-70, 2000.

HARMALKAR, M. N.; SHIRSAT, N. V. Staurosporine-Induced Growth Inhibition of Glioma Cells is Accompanied by Altered Expression of Cyclins, CDKs and CDK Inhibitors. Neurochemical Research, v. 31, p. 685-692, 2006.

HARPER, J. W.; ADAMS, P. D. Cyclin-dependent kinases. Chemical Reviews, v. 101, p. 2511-2526, 2001.

HEBERLÉ, G.; DE AZEVEDO JÚNIOR, W. F. Bio-inspired algorithms applied to molecular docking simulations. Current Medicinal Chemistry, v. 18, p. 13391352, 2011.

HE, C.; OHNISHI, K. Efficient renaturation of inclusion body proteins denatured by SDS. Biochemical and Biophysical Research Communications, v. 490, p. 1250 1253, 2017.

HENGARTNER, C. J.; MYER, V. E.; LIAO, S. M.; WILSON, C. J.; KOH, S. S.; YOUNG, K. A. Temporal regulation of RNA polymerase II by Srb10 and Kin28 cyclindependent kinases. Molecular Cell, v.2, p. 43-53, 1988. 
HOESSEL, R.; LECLERC, S.; ENDICOTT, J. A.; NOBEL, M. E.; LAWRIE, A.; TUNNAH,P.; LEOST, M.; DAMIENS, E.; MARIE, D.; MARKO, D.; NIEDERBERGER, E.; TANG, W.; EISENBRAND, G.; MEIJER, L. Indirubin, the Active Constituent of a Chinese Antileukaemia Medicine, Inhibits Cyclin-Dependent Kinases. Nature Cell Biology, v. 1, n. 1, p. 60-67, 1999.

HU, L.; BENSON, M.L.; SMITH, R.D.; LERNER, M.G.; CARLSON, H.A. Binding MOAD (Mother Of All Databases). Proteins: Structure Function and Bioinformatics, v. 60, n. 3, p. 333-340, 2005.

HUANG, N.; SHOICHET, B. K.; IRWIN, J. J. Benchmarking sets for molecular docking. Journal Medicinal Chemistry, v. 49, p. 6789-6801, 2006.

INDOLFO, Nathalia. Clonagem do cDNA e expressão da proteína quinase dependente de ciclina 8 humana. 2013. 61 f. Trabalho de Conclusão de Curso Universidade Federal de São Carlos, São Carlos, 2013.

IRWIN, J. J.; SHOICHET, B. K. Docking Screens for Novel Ligands Conferring New Biology. Journal of Medicinal Chmistry, v. 59, n. 9, p. 4103-4120, 2016.

JAYARAMAN, A.; JAMIL, K. Drug targets for cell cycle dysregulators in leukemogenesis: in silico docking studies. Plos One, v. 9, n. 1, p. 86310, 2014.

JOSHI, K. S.; RATHOS, M. J.; JOSHI, R. D.; SIVAKUMAR, M.; MASCARENHAS, M.; KAMBLE, S.; LAL, B.; SHARMA, S. In vitro antitumor properties of a novel cyclindependent kinase inhibitor P276-00. Molecular Cancer Therapeutics, v. 6, n. 3, p. 918-925, 2007.

KAPOOR, A.; GOLDBERG, M. S.; CUMBERLAND, L. K.; RATNAKUMAR, K.; SEGURA, M. F.; EMANUEL, P. O.; MENDEZ, S.; VARDABASSO, C.; LEROY, G.; VIDAL, C. I.; POLSKY, D.; OSMAN, I.; GARCIA, B. A.; HERNANDO, E.; BERNSTEIN, E. The histone variant macroH2A suppresses melanoma progression through regulation of CDK8. Nature, v. 468, n. 7327, p. 1105-1109, 2010.

KAWANISHI, N.; SUGIMOTO, T.; SHIBATA, J.; NAKAMURA, K.; MASUTANI, K.; IKUTA, M.; HIRAI, H. Structure-Based Drug Design of a Highly Potent CDK1,2,4,6 Inhibitor with Novel Macrocyclic Quinoxalin-2-one Structure. Bioorganic \& Medicinal Chemistry Letters, v. 16, p. 5122-5126, 2006.

KIM, K. S.; SACK, J. S.; TOKARSKI, J. S.; QIAN, L.; CHAO, S. T.; LEITH, L.; KELLY, Y. F.; MISRA, R. N.; HUNT, J. T.; KIMBALL, S. D.; HUMPHREYS, W. G.; WAUTLET, 
B. S.; MULHERON, J. G.; WEBSTER, K. R. Thio- and Oxoflavopiridols, CyclinDependent Kinase 1-Selective Inhibitors: Synthesis and Biological Effect. Journal of Medicinal Chemistry, v. 43, p. 4126-4134, 2000.

KNOCKAERT, M.; GREEGARD, P.; MEIJER, L. Pharmacological inhibitors cyclindependent kinases. Trends in Pharmacological Sciences, v. 23, n. 09, p. 417-425, 2002.

KNUESEL, M. T.; MEYER, K. D.; DONNER, A. J.; ESPINOSA, J. M.; TAATJES, D. J. The Human CDK8 Subcomplex Is a Histone Kinase That Requires Med12 for Activity and Can Function Independently of Mediator. Molecular and Cellular Biology, v. 29, p. 650-661, 2009.

KIM, Y.J., BJORKLUND, S., LI, Y., SAYRE, M.H. \& KORNBERG, R.D. A multiprotein mediator of transcriptional activationand its interaction with the $C$ terminal repeat domain of RNApolymerase II. Cell, v. 77, p. 599-608, 1994.

KITAGAWA, M.; OKABE, T.; OGINO, H.; MATSUMOTO, H.; SUZUKI-TAKAHASHI, I.; KOKUBO, T.; HIGASHI, H.; SAITOH, S.; TAYA, Y.; YASUDA, H. Butyrolactone I, a Selective Inhibitor of CDK2 and Cdc2 Kinase. Oncogene, v. 8, n. 9, p. 2425-2432. 1993.

KOBOR, M. S.; GREENBLATT, J. Regulation of transcription elongation by phosphorylation. Biochimica et Biophysica Acta, v. 1577, p. 261-275, 2002.

KORB, O.; STUTZLE, T.; EXNER, T. E. Empirical Scoring Functions for Advanced Protein-Ligand Docking with PLANTS. Journal of Chemical Information and Modeling, v. 49, p. 84-96, 2009.

KUBITZKI, K.; BAYER, C. Malvaceae. The Families and Genera Vascular Plants, p. 225, 2003.

KUO, P. C.; LIU, H. F.; CHAO, J. I. Survivin and p53 Modulate Quercetin-Induced Cell Growth Inhibition and Apoptosis in Human Lung Carcinoma Cells. The Journal of Biological Chemistry, v. 279, p. 55875-55885, 2004.

LAKOWICZ, Z. Principles of Fluorescence Spectroscopy. $3^{\text {a }}$ Edição. Science \& Business Media, 2007. 954 p. 
LEE, A. J.; PARK, T.; JEONG, S.; KIM, K. H.; HONG, C. 3-Hydroxychromones as Cyclin-Dependent Kinase Inhibitors: Synthesis and Biological Evaluation. Bioorganic \& Medicinal Chemistry Letters, v. 17, p. 1284-1287, 2007.

LEITCH, A. E.; HASLET, C.; ROSSI, A. G. Cyclin-dependent kinase inhibitor drugs as potencial novel antiinflamatory and pro-resolution agents. British Journal of Pharmacology, v. 158, p. 1004-1016, 2009.

LIMA, Murilo. Estudo de alcaloides quinolônicos de $\boldsymbol{W}$. brachypetala Turcz: isolamento, determinação estrutural, biogênese, atividades fungitóxica e anticolinesterase. 2012. Tese de doutorado. Universidade Federal de São carlos, São Carlos, 2012.

LIMA, M. M.; LÓPES, J. A.; DAVID, J. M.; SILVA, E. P.; GIULIETTI, A. M.; DE QUEIROZ, L. P. DAVID, J. P. Acethylcolinesterase activity of alkaloids from the leaves of Waltheria brachypetala. Planta Medica, v. 75, p. 335-337, 2009.

LIU, T.; LIN, Y.; WEN, X.; JORRISEN, R. N.; GILSON, M.K. BindingDB: a webaccessible database of experimentally determined protein-ligand binding affinities. Nucleic Acids Research, v. 35, p. 198-201, 2007.

LOSIEWICZ, M. D.; CARLSON, B. A.; KAUR, G.; SAUSVILLE, E. A.; WORLAND, P. J. Potent Inhibition of Cdc2 Kinase Activity by the Flavonoid L86-8275. Biochemical and Biophysical Research Communication, v. 201, p. 589-595, 1994.

LU, H.; CHANG, D. J.; BARATTE, B.; MEIJER, L.; SCHULZE-GAHMEN, S. Crystal Structure of a Human Cyclin-Dependent Kinase 6 Complex with a Flavonol Inhibitor, Fisetin. Journal of Medicinal Chemistry, v. 48, p. 737-743, 2005a.

LU, X.; JUNG, J.; CHO, H. J.; LIM, D. Y.; LEE, H. S.; CHUN, H. S.; KWON, D. Y.; PARK, J. H. Fisetin Inhibits the Activities of Cyclin-Dependent Kinases Leading to Cell Cycle Arrest in HT-29 Human Colon Cancer Cells. Journal of Nutrition, v. 135, p. 2884-2890, 2005b.

MAHATO, S. B.; KUNDU, A. P. ${ }^{13} \mathrm{C}$ NMR SPECTRA OF PENTACYCLIC TRITERPENOIDS-A COMPILATION AND SOME SALIENT FEATURES. Phytochemistry, v. 37, n. 6, p. 1517-1575, 1994.

MALIK, S.; ROEDER, R. G. Dynamic regulation of pol II transcription by the mammalian mediador complex. Trends in biochemical Sciences, v. 30, n. 05, p. 256-263, 2005. 
MALUMBRES, M. Cyclin-dependent kinases. Genome Biology, v. 15, n. 6, p. 2-10, 2014.

MALUMBRES, M.; HARLOW, E.; HUNT, T.; HUNTER, T.; LAHTI, J. M.; MANNING, G.; MORGAN, D. O.; TSAI, L.; WOLGEMUTH, G.; J. Cyclin-dependent kinases: a family portrait. Nature Cell Biology, v. 11, n. 11, p. 1275-1276, 2009.

MEIJER, L.; GUIDET, S.; TUNG, H. Y. L. Chemical Inhibitors of Cyclin-Dependent Kinases. Progress in Cell Cycle Research, v. 1, p. 351-363, 1995.

MEIJER, L.; KIM, S. H. Chemical inhibitors of cyclin-dependent kinases. Methods in enzymology, v. 283, p. 113-128, 1997.

MEIJER, L.; RAYMOND, E. Roscovitine and others purines as kinase inhibitors. From starfish oocytes to clinical trials. Accounts Chemical Research, v. 36, n. 6, p. 417-425, 2003.

MEYERSON, M.; ENDERS, G. H.; WU, C.; SU, L.; GORKA, C.; NELSON, C.; HARLOW, E.; TSAI, L. A family of human cdc2-related protein kinases. The EMBO Journal, v. 11, n. 18, p. 2909-2917, 1992.

MORGAN, D. O. Cyclin-dependent kinases: engines, clocks and microprocessors. Annual Review Cell Developmental Biology, v. 13, p.261-291, 1997.

MORRIS, D. G.; BRAMWELL, V. H.; TURCOTTE, R.; FIGUEREDO, A. T.; BLACKSTEIN, M. E.; VERMA, S.; MATTHEWS, S.; EISENHAUER, E. A. A Phase II Study of Flavopiridol in Patients With Previously Untreated Advanced Soft Tissue Sarcoma. Sarcoma, v. 1, p. 1-7, 2006.

MORRIS, E. J.; JI, J. Y.; YANG, F.; STEFANO, L. D.; HERR, A.; MOON, N. S.; KWON, E. J.; HAIGIS, K. M.; NÄÄR, A. M.; DYSON, N. J. E2F1 represses $\beta$-catenin transcription and is antagonized by both pRB and CDK8. Nature, v. 455, n. 7212, p. 552-556, 2008.

MYSINGER, M. M.; CARCHIA, M.; IRWIN, J. J.; SHOICHET, B. K. Directory of useful decoys, enhanced (DUD-E): better ligands and decoys for better benchmarking. Journal of Medicinal Chemistry, v. 55, n. 14, p. 6582-6594, 2012.

NEMET, J.; JELICIC, B.; RUBELJ, M. SOPTA, I. The two faces of Cdk8, a positive/negative regulator of transcription. Biochimie, v. 97, p. 22-27, 2014. 
NIEHRS, C.; ACEBRON, S. P. Mitotic and mitogenic Wnt signalling. The European Molecular Biology Organization Journal, v. 31, p. 2705-2713, 2012.

NISHIO, K.; ISHIDA, T.; ARIOKA, H.; KUROKAWA, H.; FUKUOKA, K.; NOMOTO, T.; FUKUMOTO, H.; YOKOTE, H.; SAIJO, N. Antitumor effects of butyrolactone I, a selective cdc2 kinase inhibitor, on human lung cancer cell lines. Anticancer Research, v. 16, p. 3387-3395, 1996.

NOMOTO, S.; MORI, K. Synthetic Microbial Chemistry. Part 30. Synthesis of Acetophthalidin, a Fungal Metabolite which Inhibits the Progression of the Mammalian Cell Cycle. Liebigs Annalen/Recueil, v. 4, p. 721-723, 1997.

OLSEN H. S.; NELBOCK, P.; COCHRANE, A. W.; ROSEN, C. A. Secondary structure is the major determinant for interaction of HIV rev protein with RNA. Science, v. 247, n. 4944, p. 845-848, 1990.

ONINSON, I. B.; BROUDE, E. V. Inhibition of CDK8 mediator kinase suppresses estrogen dependent transcription and the growth of estrogen receptor positive breast câncer. Oncotarget, v. 8, n. 8, p. 12558-12575, 2017.

ONO, K.; BANNO, H.; OKANIWA, M.; HIRAYAMA, T.; IWAMURA, N.; HIKICHI, Y.; MURAI, S.; HASEGAWA, M.; HASEGAWA, Y.; YONEMORI, K.; HATA, A.; AOYAMA, K.; CARY, D. R. Design and synthesis of selective CDK8/19 dual inhibitors: Discovery of 4,5-dihydrothieno[3',4':3,4]benzo[1,2-d]isothiazole derivatives. Bioorganic \& Medicinal Chemistry, v. 25, n. 8, p. 2336-2350, 2017.

ORGANIZAÇÃO MUNDIAL DE SAÚDE (OMS). MULHERES e SAÚDE: evidências de hoje agenda de amanhã. Brasil, 2009. Disponível em $<$ http://www.who.int/eportuguese/publications/Mulheres_Saude.pdf?ua=1>. Acesso em: 10 Mar. 2009.

ORPHANIDES, G.; REINBERG, D. A unified theory of gene expression. Cell, v. 108, p. 439-451, 2002.

PALANCADE, B.; BENSAUDE, O. Investigating RNA polymerase II carboxil-terminal domain kinases display distinct substrate preferences. Journal Biological Chemistry, v. 270, n. 19, p. 3859-3870, 2003. CDK11 humanas utilizando um sistema bacteriano de expressão (E. coli). 2015. 
128 f. Dissertação de mestrado em química orgânica e biológica - Instituto de Química de São Carlos, Universidade de São Paulo, São Carlos, 2015.

PHATNANI, H. P.; GREENLEAF, A. L. Phosphorylation and functions of the RNA polymerase II CTD. Genes \& Development, v. 20, p. 2922-2936, 2006.

PEYRESSATRE, M.; PRÉVEL, C.; PELLERANO, M.; MORRIS, M. C. Targeting Cyclin-Dependent Kinases in Human Cancers: From Small Molecules to Peptide Inhibitors. Cancers, v. 7, p. 179-237, 2015.

POLYCHRONOPOULOS, P.; MAGIATIS, P.; SKALTSOUNIS, A. L.; MYRIANTHOPOULOS, V.; MIKROS, E.; TARRICONE, A.; MUSACCHIO, A.; ROE, S. M.; PEARL, L.; LEOST, M.; GREENGARD, P.; MEIJER, L. Structural Basis for the Synthesis of Indirubins as Potent and Selective inhibitors of Glycogen Synthase Kinase-3 and Cyclin-Dependent Kinases. Journal of Medicinal Chemistry, v.47, n. 4, p. 935-946, 2004.

KOSMOPOULOU, M. N.; LEONIDAS, D. D.; CHRYSINA, E. D.; BISCHLER, N.; EISENBRAND, G.; SAKARELLOS, C. E.; PAUPTIT, R.; OIKONOMAKOS, N. G. Binding of the Potential Antitumour Agent Indirubin-5-sulphonate at the Inhibitor Site of Rabbit Muscle Glycogen Phosphorylase b. Comparison with Ligand Binding to $\mathrm{pCDK}$ /cyclin A Complex. European Journal of Biochemistry, v. 271, n. 11, p. 2280-2290, 2004.

RAMANATHAN, Y. S.; RAJPARA, M.; REZA, S. M.; LEES, E.; SHUMANS, S.; MATHEWS, M. B.; P'EERY, T. Three RNA polymerase II carboxil-terminal domain kinases display distinct substrate preferences. The Journal of Biological Chemistry, v. 276, n. 14, p 10913-10920, 2001.

REINHARDT, H. C.; SCHUMACHER, B.The p53 network: cellular and systemic DNA damage responses in aging and cancer, Trends in Genetics, v. 28, p. 128-136, 2012.

REN, S.; ROLLINS, B. J. Cyclin C/CDK3 promotes Rb-dependent G0 exit. Cell, v. 117, p. 239-251, 2004.

RIBAS, J.; BETTAYEB, K.; FERANDIN, Y.; KNOCKAERT, M.; GARROFE-OCHOA, X.; TOTZKE, F.; SCHACHTELE, C.; MESTER, J.; POLYCHRONOPOULOS, P.; MAGIATIS, P.; SKALTSOUNIS, A. L.; BOIX, J.; MEIJER, L. 7-Bromoindirubin-3'- 
oxime Induces Caspase-Independent Cell Death. Oncogene, v. 25, p. 6304-6318, 2006.

RICKERT, P.; CORDEN, J. L.; LEES, E. Cyclin C/CDK8 and cyclin H/CDK7/p53 are biochemically distinct CTD kinases. Oncogene, v.18, p. 1093-1102, 1999.

ROSSI, A. G.; HALLETT, C.; SAWATZKY, D. A.; TEIXEIRA, M. M.; HASLETT, C. Modulation of granulocyte apoptosis can influence the resolution of inflammation. Biochemical SocietyTransactions, v. 35, p. 288-291, 2006.

RZYMSKI, T.; MIKULA, M.; WIKLIK, K.; BRZÓZKA, K. CDK8 kinase-An emerging target in targeted cancer therapy. Biochimica et Biophysica Acta, v. 1854, p. 16171629, 2015.

SABA, M. D.; SANTOS, F. A. R. Morfologia polínica de Sterculiaceae das dunas do Abaeté, Salvador-BA. Revista de Ciências Biológicas da UEFS, v. 3, p. 109-114, 2003.

SAGE, J.; MILLER, A. L.; PÉREZ-MANCERA, P. A.; WISOCK, J. M.; JACKS, T. Acute mutation of retinoblastoma gene function is suficiente for cell cycle re-entry. Nature, v. 424, p. 223-228, 2003.

SCHMITZ, F. J.; GUNASEKERA, S. P.; LAKSHMI, V.; TILLEKERATNE, L. M. V. Marine Natural Products: Pyrrololactams from Several Sponges. Journal of Natural Products, v. 48, p. 47-53, 1985.

SAMBROOK, J.; RUSSEL, D. W. Molecular Cloning: A Laboratory Manual. $3^{\text {a }}$ Ed. Nova York: Cold Spring Harbor Laboratory Press, 2001, 2100 p.

SCHNEIDER, E. V.; BÖTTCHER, J.; BLAESSE, M.; NEUMANN, L.; HUBER, R.; MASKOS, K. The Structure of CDK8/CycC Implicates Specificity in the CDK/Cyclin Family and Reveals Interaction with a Deep Pocket Binder. Journal of Molecular Biology, v. 412, p. 251-266, 2011.

SCHNEIDER, E. V.; BÖTTCHER, J.; HUBER, R.; MASKOS, K.; NEUMANN, L. Structure-kinetic relationship study of $\mathrm{CDK} 8 / \mathrm{CycC}$ specific compounds.

Proceedings of the National Academy of Sciences, v. 110, n. 20, p. 808180866, 2013.

SCHOEPFER, J.; FRETZ, H.; CHAUDHURI, B.; MULLER, L.; SEEBER, E.; MEIJER, L.; LOZACH, O.; VANGREVE-LINGHE, E.; FURET, P. Structure-Based Design and Synthesis of 2-Benzylidene-benzofuran-3-ones as Flavopiridol Mimics. Journal of Medicinal Chemistry, v. 45, p. 1741-1747, 2002. 
SEDLACEK, H. H.; CZECH, J.; NAIK, R.; KAUR, G.; WORLAND, P.; LOSIEWICH, M.; PARKER, B.; CARLSON, B.; SMITH, A. Flavopiridol (L86-8275; NSC 649890), a New Kinase Inhibitor for Tumor Therapy. International Journal of Oncology, v. 9, p. 1143-1168, 1996.

SENDEROWICZ, A. M. Inhibitors of Cyclin-Dependent Kinase Modulators for Cancer Therapy. Progress in Drug Research, v. 63, p. 183-206, 2005.

SHARMA, P. S.; SHARMA, R.; TYAGI, R. Inhibitors of Cyclin Dependent Kinases: Useful Targets for Cancer Treatment. Current Cancer Drug Targets, v. 8, p. 53-75, 2008.

SIELECKI, T. M.; BOYLAN, J. F.; BENFIELD, P. A.; TRAINOR, G. L. CyclinDependent Kinase Inhibitors: Useful Targets in Cell Cycle Regulation. Journal of Medicinal Chemistry, v. 43, p. 1-18, 2000.

SKOTHEIM, J. M.; DI TALIA, S.; SIGGIA, E. D.; CROSS, F. R. Positive feedback of G1 cyclins ensures coherent cell cycle entry. Nature, v. 454, n. 7202, p. 291-296, 2008.

SMITH, G. K.; KE, Z.; GUO, H.; HENGGE, A. C. Insights into the phosphoryl transfer mechanism of cyclin-dependent protein kinases from ab initio QM/MM free-energy studies. The Journal of Physical Chemistry B, v. 115, n. 46, p. 13713-13722, 2011.

SONI, R.; MULLER, L.; FURET, P.; SCHOEPFER, J.; STEPHAN, C.; MECKER, S. Z.; FRETZ, H.; CHAUDHURI, B. Inhibition of Cyclin-Dependent Kinase 4 (Cdk4) by Fascaplysin, a Marine Natural Product. Biochemical and Biophysical Research Communications, v. 275, p. 877-884, 2000.

SZILAGYI, Z.; GUSTAFSSON, C. M. Emerging roles of Cdk8 in cell cycle control. Biochimica et Biophysica Acta, v. 1829, p. 916-920, 2013.

TAATJES, D. I.; NAAR, A. M.; ANDEL III, F.; NOGALES, E.; TIIAN, R. Structure, function, and activator-induced conformations of the CRSP coactivator. Science, v. 295, p. 1058-1062, 2002.

TAKAHASHI, Y.; RAYMAN, J. B.; DYNLACHT, B. D. Analysis of promoter binding by the $\mathrm{E} 2 \mathrm{~F}$ and $\mathrm{pRb}$ families in vivo: distinct E2F proteins mediate activation and repression. Genes \& Development, v. 14, p. 804-816, 2000. 
TALLURI, S.; DICK, F. A. Regulation of transcription and chromatin structure by pRB Here, there and everywhere. Cell Cycle, v. 11, n. 17, p. 3189-3198, 2012.

THOMSEN, R.; CHRISTENSEN, M. H. MolDock: a new technique for highaccuracy molecular docking. Journal of Medicinal Chemistry, v. 49, n. 11, 3315-3321, 2006.

TOOGOOD, P. L. Cyclin-Dependent Kinase Inhibitors for Treating Cancer. Medicinal Research Reviews, v. 6, p. 487-498, 2001.

TRIMARCH, J. M.; LEES, J. A. Sibling rivalry in the E2F family. Nature Reviews Molecular Cell Biology, v. 3, p. 11-20, 2002.

UPADHYAY, V.; SINGH, A.; JHA, D.; SINGH, A.; PANDA, A. K. Recovery of bioactive protein from bacterial inclusion bodies using trifluoroethanol as solubilization agente. Microbial Cell Factories, v. 15, p. 1-13, 2016.

VIJAYABABU, M. R.; KANAGARAJ, P.; ARUNKUMAR, A.; ILANGOVAN, R.; ARULDHAS, M. M.; ARUNAKARAN, J. Quercetin-Induced Growth Inhibition and Cell Death in Prostatic Carcinoma Cells (PC-3) are Associated with Increase in p21 and Hypophosphorylated Retinoblastoma Proteins Expression. Journal of Cancer Research and Clinical Oncology, v. 131, n. 11, p. 765-771, 2005.

WADA, M.; HOSOTANI, R.; LEE, J. U.; DOI, R.; KOSHIBA, T.; FUJIMOTO, K.; MIYAMOTO, Y.; TSUJI, S.; NAKAJIMA, S.; OKUYAMA, A.; IMAMURA, M. An exogenous cdk inhibitor, butyrolactone-I, induces apoptosis with increased $\mathrm{Bax} / \mathrm{Bcl}-2$ ratio in p53-mutated pancreatic cancer cells. Anticancer Research, v. 18, p. 2559-2566, 1998.

WANG, R.; FANG, X.; LU, Y.; WANG, S. The PDBbind Database: Collection of Binding Affinities for Protein-Ligand Complexes with Known Three-Dimensional Structures. Journal of Medicinal Chemistry, v. 47, n. 12, p. 2977-2980, 2004.

WANG, T.; YANG, Z.; ZHANG, Y.; YAN, W.; WANG, F.; HE, L.; ZHOU, Y.; CHEN, L. Discovery of novel CDK8 inhibitors using multiple crystal structures in docking-based virtual screening. Europe Journal Medicinal Chemistry, v. 129, p. 275-286, 2017.

WAN, Y.; HUR, W.; CHO, C. Y.; LIU, Y.; ADRIAN, F. J.; LOZACH, O.; BACH, S.; MAYER, T.; FABBRO, D.; MEIJER, L.; GRAY, N. S. Synthesis and Target Identification of Hymenialdisine Analogs. Chemistry \& Biology, v. 11, p. 247-259, 2004. 
WATSON, J. D.; BAKER, T. A.; BELL, S. P.; GANN, A.; LEVINE, M.; LOSICK, R. Biologia Molecular do gene. $7^{\mathrm{a}}$ ed. Artmed, 2015, $912 \mathrm{p}$.

WESTBROOK, J.; FENG, Z.; CHEN, L.; YANG, H.; BERMAN, H. M. The Protein Data Bank and structural genomics. Nucleic Acids Research, v. 31, p. 489-491, 2003.

WIRGER, A.; PERABO, F. G.; BURGEMEISTER, S.; HAASE, L.; SCHMIDT, D. H.; DOEHN, C.; MUELLER, S. C.; JOCHAM, D. Flavopiridol, an Inhibitor of CyclinDependent Kinases, Induces Growth Inhibition and Apoptosis in Bladder Cancer Cells in vitro and in vivo. Anticancer Research, v. 25, p. 4341-4347, 2005.

WONG, A.S.L.; LEE, R.H.K.; CHEUNG, A.Y.; YEUNG, P.K.; CHUNG, S.K.; CHEUNG, Z.H.; IP, N.Y. Cdk5-mediated phosphorylation of endophilin B1 is required for induced autophagy in models of Parkinson's disease. Nature Cell Biology, v. 13, p. 568-579 2011.

XAVIER, M. M.; HECK, G. S.; DE AVILA, M. B.; LEVIN, N. M.; PINTRO, V. O.; CARVALHO, N. L.; AZEVEDO JÚNIOR, W. F.; SAnDReS a Computational Tool for Statistical Analysis of Docking Results and Development of Scoring Functions. Combinatorial Chemistry \& High Throughput Screening, v. 19, n. 10, p. 801-812, 2016.

XU, X.; HUANG, M.; ZOU, X. Docking-based inverse virtual screening: methods, applications, and challenges. Biophysics Reports, v. 4, n. 1, p. 1-16, 2018.

YAMAMOTO, H.; MONDEN, T.; MIYOSHI, H.; IZAWA, H.; IKEDA, K.; TSUJIE, M.; OHNISHI, T.; SEKIMOTO, M.; TOMITA, N.; MONDEN, M. Cdk2/cdc2 expression in colon carcinogenesis and effects of cdk2/cdc2 inhibitor in colon cancer cells.

International Journal of Oncology, v. 13, p. 233-239, 1998.

YANG, F.; MOSS, L.G.; PHILLIPD JÚNIOR, G. N. The molecular structure of green fluorescent protein. Nature Biotechnology, v. 14, p. 1246-1251, 1996.

ZHAO, Y.; LI, K. K. C.; NG, K. P.; NG, C. H.; LEE, K. A. W. The RNA Pol II subcomplex hsRpb4/7 is required for viability of multiple human cell lines. Protein Cell, v. 3, n. 11, p. 846-854, 2012. 